UNIVERSIDADE DE SÃO PAULO

ESCOLA DE COMUNICAÇÕES E ARTES

Departamento de Artes Cênicas

Carolina Bassi de Moura

\title{
A construção plástica dos personagens cinematográficos \\ Uma abordagem feita a partir da obra de Federico Fellini
}


Carolina Bassi de Moura

\section{A Construção Plástica dos Personagens \\ Cinematográficos - \\ Uma abordagem a partir da obra de Federico Fellini}

Dissertação apresentada à Escola de Comunicações e Artes da Universidade de São Paulo para obtenção do título de Mestre em Artes Cênicas.

Área de Concentração:

Teoria e Prática do Teatro

Orientador:

Fausto Roberto Poço Viana 
Nome: Carolina Bassi de Moura

Título: A Construção Plástica dos Personagens Cinematográficos

Subtítulo: Uma abordagem feita a partir da obra de Federico Fellini

Dissertação apresentada à Escola de Comunicações e Artes da Universidade de São Paulo para obtenção do título de Mestre em Artes Cênicas. Área de Concentração: Teoria e Prática do Teatro.

Aprovado em:

\section{Comissão Julgadora}

Orientador:

Prof. Dr. Fausto R. Poço Viana Instituição:

Escola de Comunicações e Artes

Universidade de São Paulo

Membro:

Instituição:

Membro:

Instituição:
Assinatura:

Julgamento:

Assinatura:

Julgamento:

Assinatura: 
Dedico esta pesquisa a meus pais, amigos incríveis, meus primeiros interlocutores na vida e nas artes.

E dedico também essa pesquisa a todos os que sabem que graça tem fazer tudo isso! 


\section{AGRADECIMENTOS}

Agradeço à Universidade de São Paulo e à FAPESP (Fundação de Amparo à Pesquisa) pelo suporte dado a estes estudos permitindo que este trabalho fosse feito de forma tão completa.

Agradeço ao Prof. Fausto, pela orientação presente e pelo entusiasmo sempre! Obrigada por todas as luzes que me ajuda a acender sobre esse assunto tão interessante. (E ainda há muitas lamparinas no caminho!)

Agradeço aos membros da banca pela leitura cuidadosa e por todas as importantes contribuições para meu trabalho.

Agradeço aos professores que conheci no início da jornada apresentando minha idéia, pela delicadeza de me apontarem algum fiapo que fosse nesse grande novelo, mesmo não sendo essa a sua especialidade. E aos professores das disciplinas, que acrescentaram novos pontos de vista.

Agradeço profundamente a todos os velhos e novos amigos que esta jornada me trouxe: pela cumplicidade, gentileza, paciência e confiança!

Aos meus pais, queridos e amados, Fernando e Josana, agradeço por tudo, tudo mesmo - o carinho infinito, o incentivo constante e todo o apoio que é necessário para alcançar os sonhos! Sempre.

À minha amiga Clissia, que concordou que estudo e trabalho fossem atividades paralelas. Com ela divido muitas coisas essenciais: a amizade, o afeto, uma coleção de histórias! Além dos filmes que "desenhamos" juntas e de todos aqueles que ainda virão!

Ao meu amor, Frederico, companheiro da minha alma e do meu coração, obrigada por toda a paciência e cuidado nessa reta final. Por sua presença ávida em minha vida, querido. 


\section{Resumo}

Esta pesquisa analisa o caráter fundamental dos recursos plásticos de figurino e cenário para o processo de construção do personagem no cinema. Verifica a importância de uma direção de arte mais livre ao fazer suas composições, ao optar por formas e cores que sejam mais coerentes com ideias e sensações do que com reproduções realistas. O estudo se faz a partir da obra cinematográfica de Federico Fellini, diretor despreocupado com concepções realistas e criador de um processo criativo muito próprio. Serão considerados especificamente os filmes La Strada (1954), Julieta dos Espíritos (1965) e Toby Dammit ${ }^{1}$ (1967), por serem emblemáticos desta construção plástica fortemente elaborada.

Palavras-chave: Construção de Personagem; Direção de Arte; Federico Fellini.

\footnotetext{
${ }^{1}$ Toby Dammit é o terceiro episódio de um compêndio intitulado Histórias Extraordinárias, que reúne três filmes de curta-metragem adaptados de contos de Edgar Allan Poe. Os outros episódios são Metzengertein e William Wilson, de Roger Vadin e Louis Malle, respectivamente.
} 


\begin{abstract}
This research verifies the fundamental character of visual resources like costumes and scenery for the process of construction of the characters on cinema. Verifies the importance of more freedom for art direction making its compositions, opting for forms and colors more coherent with ideas and sensations than realistic reproductions. The study is made from cinematographic works of Federico Fellini, director which is unworried with realistic conceptions and which is creator of a creative process very particular. In this work will be considered specifically three films, La Strada (1954), Julieta dos Espíritos (1965) e Toby Dammit ${ }^{2}$ (1967), because of their emblematic visual construction strongly worked.
\end{abstract}

Keywords: Character's Construction; Art Direction; Federico Fellini.

\footnotetext{
${ }^{2}$ Toby Dammit is the third episode from a compendium known Histoires Extraordinaires, which include three films adapted from Edgar Allan Poe histories. The others episodes are Metzengertein and William Wilson, of Roger Vadin and Louis Malle, respectively.
} 


\section{LISTA DE IMAGENS}

Capítulo 1

Imagem 1 e 2 Cenas de filmes de Georges Mélièt ................................. 19

Imagem 3 Cena de La Presa di Roma, de Alberini, 1905......................... 20

Imagens de 4 a 7 Cenas de Cabíria, de Pastrone, 1914 .......................... 21

Imagem 8 Esquema de Pastrone para Travelling .................................. 22

Imagem 9 Pais de Fellini .............................................................................. 33

Imagem 10 Desenho de Fellini para maquiagem Casanova ................. 40

Imagem 11 Caracterização Casanova....................................................... 40

Imagem 12 La Bimba Atomica............................................................. 41

Imagem 13 Auto retrato Fellini ............................................................... 47

Capítulo 2

Parte A

Análise dos personagens do filme La Strada

Imagens de 1 a 35 Fotogramas do filme La Strada........................... 57-65

Imagens 36 e 37 Gelsomina ................................................................ 65-66

Imagens 38 e 39 Desenhos de Fellini para personagem Gelsomina..... 67

Imagem 40 Giulietta Masina sendo caracterizada ................................ 68

Imagens 41 e 42 Desenhos de Fellini para personagem Gelsomina..... 69

Imagem 43 Desenho de Fellini para motoneta de Zampanò.................. 70

Imagem 44 Motoneta de Zampanò em cena............................................ 70

Imagem 45 Zampanò .................................................................................. 71

Imagens 46 e 47 Desenhos de Fellini para personagem Zampanò .. 71-72

Imagem 48 Zampanò ................................................................................ 73

Imagem 49 Fellini e Richard Basehart em set de filmagem ................... 74

Imagem 50 Desenho de Fellini para personagem II Matto ou Louco .... 74

Imagens 51 e 52 II Matto ou Louco.................................................... 74-75

Imagem 53 Última briga de Zampanò e Louco.................................... 76

Parte B

Análise dos personagens do filme Julieta dos Espíritos

Imagens de 54 a 66 Fotogramas do filme Julieta dos Espíritos ....... 81-90

Imagem 67 Desenho de Fellini para personagem Julieta ..................... 91

Imagens de 68 a 110 Fotogramas do filme Julieta dos Espíritos ... 92-122

Parte C

Análise dos personagens do filme Toby Dammit

Imagens 111 e 112 Fotogramas do filme Toby Dammit........................ 127

Imagens 113 Desenho de Fellini personagem Toby Dammit e cena com

os três persoangens no carro .................................................................. 127

Imagens 114 e 115 Fotogramas do filme Toby Dammit........................ 130

Imagens 116 e 117 Desenhos de Fellini personagem Toby Dammit... 132

Imagem 118 Fotografia de Edgar Allan Poe ....................................... 132

Imagens de 119 a 123 Fotogramas do filme Toby Dammit............ 133-134

Imagem 124 Desenho de Fellini para personagem Menina-Diabo ...... 135 
Imagens de 125 a 154 Fotogramas do filme Toby Dammit. $136-146$

Capítulo 3

Desdobramentos do Cinema de Fellini - Considerações Finais

Imagens de 1 a 4 Desenhos e fotos - Personagens de Alice de Tim

Burton

Imagens de 5 a 8 Desenhos e fotogramas - Vincent de Tim Burton .. 150-

151

Imagens de 9 a 11 Desenhos e foto - Personagem de Edward Mãos de

Tesoura de Tim Burton.................................................................... 151-152

Imagem 120 cineasta Tim Burton........................................................ 153

Imagens 13 e 18 Desenhos e fotos - Personagens de Batman Returns

de Tim Burton. 153

Imagens de 19 a 22 Cenas do filme Delicatessen de Jean-Pierre Jeunet

Imagens 23 e 24 Cenas do filme O Fabuloso Destino de Amelie Poulain

de Jean-Pierre Jeunet........................................................................... 156

Imagem 25 Fotograma - Cenário da cidade de Ladrão de Sonhos .... 157

Imagens de 26 a 30 Desenhos e fotos - Personagem Miette........ 157-158

Imagens de 31 a 34 Desenhos e fotos - Personagem Tentácula ........ 158

Imagens de 35 a 37 Desenhos e fotos - Personagem Dr. Krank .......... 159

Imagens 38 e 39 Fotogramas - Apresentação de One semelhante a de

Zampanò .................................................................................................... 159

Imagens de 40 a 45 Desenhos e fotos - Caracterização e cenário ..... 160

Imagens de 46 a 50 Cenários - preparação e resultado.................. 161-162

Imagens 51 e 52 Desenho e Cenário da Casa - O Labirinto do Fauno 163

Imagem 53 Personagens Ofélia e Mercedes ........................................... 164

Imagem 54 Desenho para personagens Ofélia ..................................... 165

Imagem 55 e 56 Dois figurinos de Ofélia............................................... 165

Imagens de 57 a 62 Desenhos e fotos - Personagem Fauno ....... 165-166

Imagens de 63 a 67 Desenhos e fotos - Personagem Homem Pálido 166

Imagem 68 Desenhos e anotações de Luiz Fernando Carvalho para

Lavoura Arcaica ..................................................................................... 167

Imagens de 69 a 74 Cenários Capitu ............................................... 168-169

Imagens de 75 a 78 Equipe Fellini movimentando "mar de plástico" 170

Imagem 79 Cenário Capitu................................................................. 171

Imagem 80 Cenário Nine ....................................................................... 172

Imagem 81 Cena final de Oito e Meio.................................................... 173

Imagem 82 Personagem Luísa no filme Nine...................................... 174

Imagem 83 Personagem Luísa no filme Oito e Meio ............................. 175

Imagem 84 Personagem Carla no filme Oito e Meio.............................. 175

Imagem 85 Atriz cobiçada em Oito e Meio ............................................. 176

Imagem 86 Atriz cobiçada em Nine......................................................... 176

Imagem 87 Atriz "diva" em La Dolce Vita - Anita Ekberg..................... 176

Imagem 88 Personagem Carla no flme Nine ......................................... 177

Imagem 89 Personagem Carla no filme Oito e Meio.............................. 177

Imagens 90 e 91 Personagens pais de Guido no filme Oito e Meio .... 177

Imagem 92 Personagem mãe de Guido em Nine ................................. 177

Imagem 93 Personagem Gradisca de Amarcord .................................. 177 
Imagem 94 Personagem Saraghina no filme Oito e Meio ..................... 178

Imagem 95 Personagem Saraghina no filme Nine............................. 178

Imagem 96 Desenho do personagem Poeta, peça Ruas de Barros .... 182

Imagem 97 Foto do Poeta, peça Ruas de Barros................................ 182

Imagem 98 Foto do personagem Ânima, peça Ruas de Barros .......... 182

Imagem 99 Desenho do personagem Ânima, peça Ruas de Barros... 182

Imagem 100 Desenho do personagem D. Maria, peça Ruas de Barros

Imagem 101 Foto do personagem D. Maria, peça Ruas de Barros ..... 183

Imagem 102 a 104 Fotos de cena da peça Ruas de Barros 


\section{SUMÁRIO}

Introdução

\section{Capítulo 1 - O Cinema e Fellini}

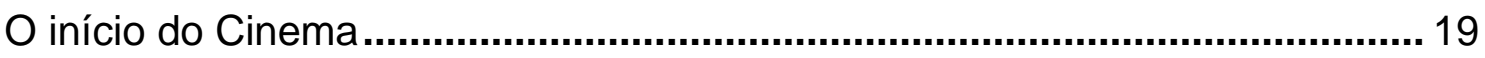

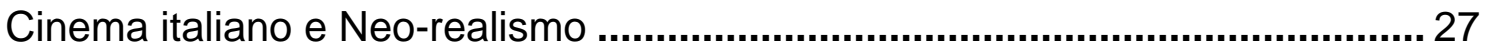

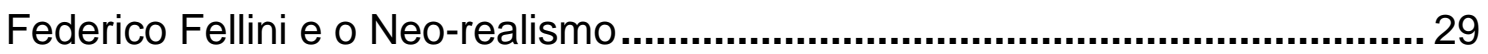

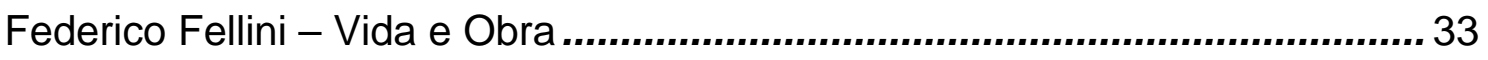

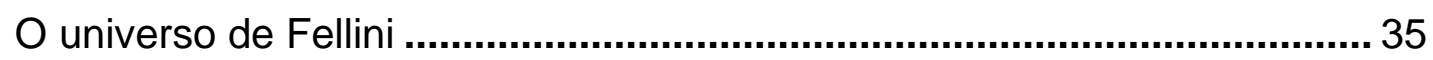

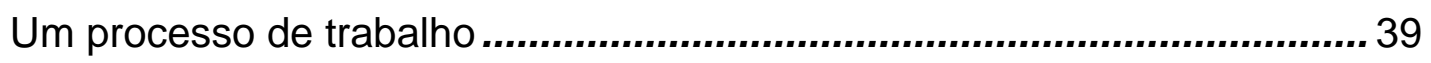

O aspecto plástico - nas Artes e no Cinema.....................................................4 44

Sobre a construção geral do personagem .................................................... 52

\section{Capítulo 2 - Análise da construção plástica dos personagens} nos filmes: La Strada, Julieta dos Espíritos e Toby Dammit

\section{A) Análise da construção dos personagens no filme La Strada}

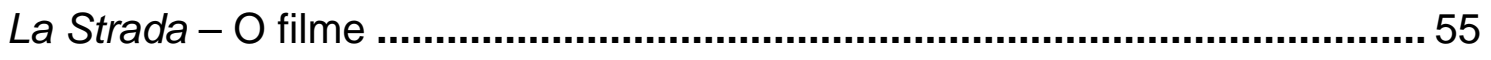

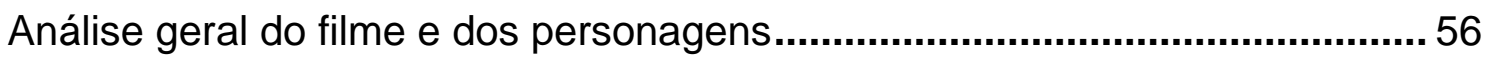

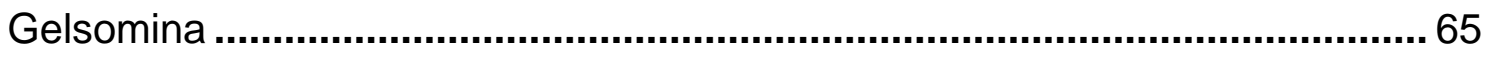

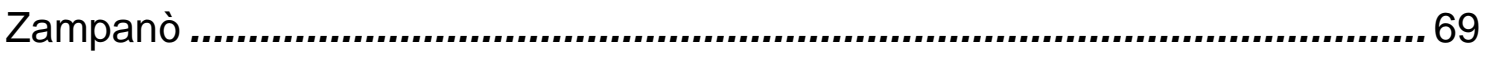

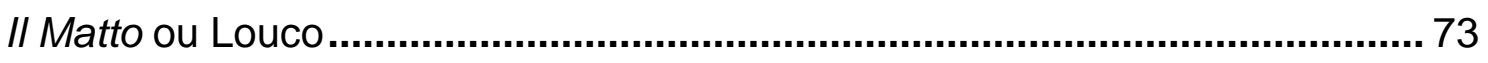

B) Análise da construção dos personagens no filme Julieta dos Espíritos

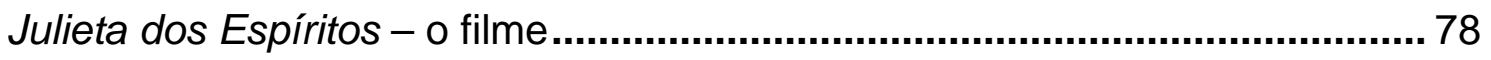

Análise de Figurinos e Cenários dos personagens Julieta, Susy e secundários

C) Análise da construção dos personagens no filme Toby Dammit

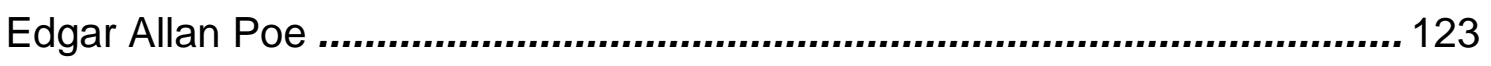

O conto - Nunca aposte sua cabeça com o diabo ........................................ 124 
Toby Dammit - o filme

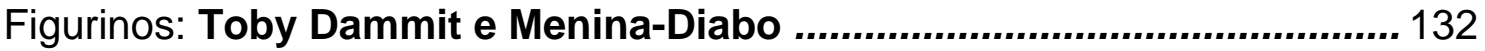

Cenários: Aeroporto, Ruas de Roma, Estúdio de TV, Festa, Cidade........ 137

\section{Capítulo 3 - Desdobramentos do Cinema de Fellini -}

\section{Considerações Finais}

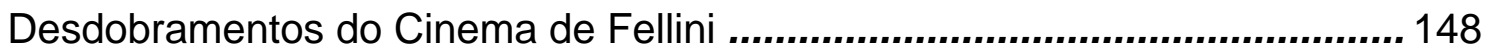

Tim Burton................................................................................................. 148

Jean-Pierre Jeunet ........................................................................................... 154

Guillermo Del Toro - O Labirinto do Fauno... Erro! Indicador não definido.163

Luiz Fernando Carvalho .............................................................................. 167

Aproximação equivocada - o caso Nine ................................................... 172

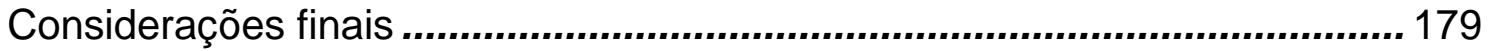

\section{Referências}

\section{Bibliografia}

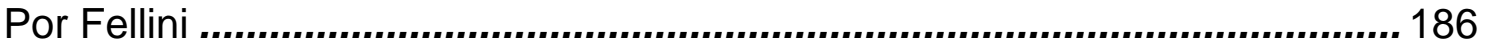

Sobre Fellini .................................................................................................. 186

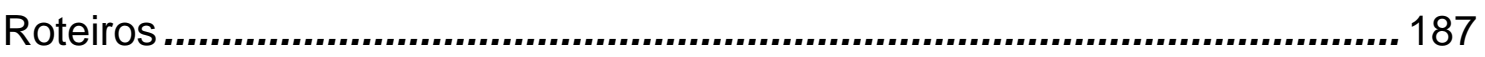

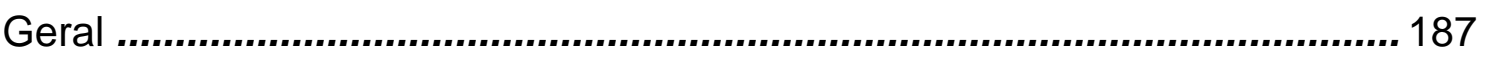

\section{Filmografia}

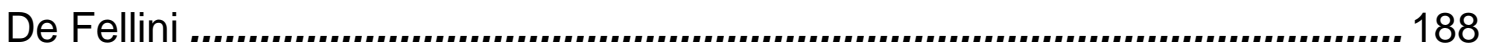

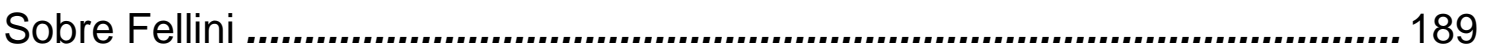

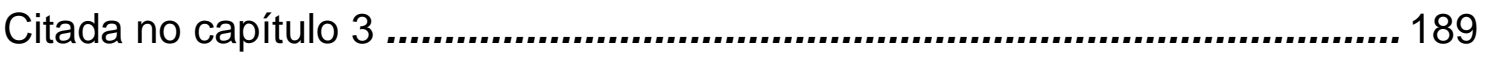


Esta pesquisa recebeu o apoio da FAPESP, Fundação de Amparo à Pesquisa do Estado de São Paulo 
Se afirmo ser confiante, não quero parecer uma alegre mariposa voando de flor em flor, mas uma pessoa que se sente viva, que ainda não esgotou sua aventura humana. No fundo, tudo na vida me agrada e às vezes sinto-me cheio de uma eletrizante curiosidade, como se ainda não tivesse nascido. Sim, ainda não perdi a confiança na viagem, embora muitas vezes esta viagem possa parecer desesperante e escura.

O importante para o homem de hoje é manter o tipo, não esconder a cabeça, mas acima de tudo saber olhar além do túnel, criando inclusive um ponto de salvação, com fantasia, vontade e, principalmente, com confiança. Neste sentido creio que a obra dos artistas de hoje em dia é indispensável.

Federico Fellini 


\section{INTRODUÇÃO}

A Construção Plástica dos Personagens Cinematográficos - uma abordagem feita a partir da obra de Federico Fellini investiga a contribuição dos recursos plástico-visuais no processo de construção do personagem no cinema.

Sendo o cinema uma arte audiovisual, suas imagens possuem grande relevância e não devem ser compostas de modo desatento. Afinal, histórias cinematográficas são narradas por imagens, tanto quanto, ou mais, do que por palavras. Sabemos, podemos fazer cinema sem usar nenhuma palavra, mas não o contrário.

No estudo da construção plástica do personagem no cinema, restrinjo esta pesquisa aos recursos de cenário, figurino e acessórios - componentes da direção de arte. E para iniciar minha investigação escolhi como objeto de estudo a obra do diretor de cinema italiano Federico Fellini devido à sua forte elaboração plástica e seu desprendimento de representações estritamente realistas.

Utilizarei especificamente três filmes do diretor, La Strada (1954), Julieta dos Espíritos (1965) e Toby Dammit (1967), que considero excelentes exemplos dessa plasticidade a ser analisada. Além disso, são filmes "de personagem", ou seja, um tipo de filme onde os personagens são ainda mais importantes para a narrativa e por essa razão precisam ser muito mais bem construídos.

A decisão de realizar esta pesquisa veio da vontade e da necessidade de estudar o assunto para trabalhar melhor com cinema (e por que não estender este aprendizado ao teatro e à televisão?). Já na graduação eu procurava por uma bibliografia através da qual eu pudesse estudar o assunto, que considerava muito interessante. Depois de conversar com professores em diferentes departamentos de algumas importantes universidades no estado de São Paulo, descobri a relevância da pesquisa - descobri que não havia nada escrito especificamente sobre o assunto no país.

Há, de fato, escasso material desenvolvido em torno desta questão, portanto, esta pesquisa vem auxiliar não apenas críticos e pesquisadores na análise de filmes, mas também os realizadores do cinema a repensarem seu 
processo criativo e a melhorarem sua elaboração no nível plástico, de modo a acrescentar outras camadas em seus trabalhos e torná-los mais interessantes e profundos.

No primeiro capítulo será abordado o surgimento do cinema, que desde o início manifestou duas vertentes muito claras: uma mais realista e outra mais fantástica. Será feita uma rápida passagem pela evolução do cinema na Itália, passando pela história do famoso filme Cabíria (1914), pelo neo realismo até chegarmos aos filmes de Fellini. Sobre o diretor serão apresentados dados de sua biografia que interferiram direta ou indiretamente em sua filmografia e será apresentado também seu autêntico processo criativo.

Uma amostragem do estudo teórico feito para analisar os filmes será dada neste capítulo e serão articulados os referenciais teóricos entre si para esclarecer o modo como encaro a elaboração do aspecto plástico no cinema.

No segundo capítulo está concentrada a análise dos três filmes escolhidos. Foram levados em consideração os roteiros, a época em que foram realizados, a biografia do diretor, seu processo criativo e os documentos escritos ou filmados, que foram deixados sobre as referidas obras. No caso de Toby Dammit foi levado também em consideração o conto Nunca Aposte sua Cabeça com o Diabo que serviu como base para a livre adaptação feita por Fellini, assim como o universo da obra de Edgar Alan Poe e a biografia deste autor.

Para o terceiro e último capítulo, reservo um espaço para avaliar possíveis desdobramentos do cinema de Fellini em obras cinematográficas e audiovisuais contemporâneas. Não creio, de fato, que haja nenhum cineasta que se equipare à genialidade de Fellini, mas creio que haja muitos bons frutos gerados a partir de seu trabalho.

Como profissional de direção de arte em cinema e em teatro inserida no mercado atual é que considero importante este estudo. Para que entendamos melhor sobre este processo de trabalho tão minucioso, tão bem realizado e que nos atinge com tamanha força.

Assim, mesmo com todas as agruras do trabalho, comuns no mercado cultural brasileiro, não perco a fé no cinema, no teatro, na poesia. Ao contrário, me inspiro e desejo seguir muito em frente! Com Fellini volto às minhas vontades primeiras e me lembro perfeitamente de quanto elas são importantes. 
Com seu cinema volto a mim como pessoa, humana, que deseja expressar-se e colaborar para a felicidade desse mundo, pelo menos um pouco, com a graça e o ímpeto do meu trabalho profissional e também acadêmico. 
Capítulo 1

\section{O Cinema e Fellini}




\section{O início do Cinema}

A arte do cinema poderia ser encarada como uma sucessora da fotografia, uma vez que o cinema parte da matriz fotográfica, como "células" que sequencialmente provocam em nossa retina a ilusão de movimento. Mas o registro da ação, do gesto prolongado no tempo, se diferencia da fotografia criando a necessidade de desenvolver uma complexa e particular linguagem.

O primeiro sistema a aproximar-se do que conhecemos como cinema chamava-se cinematógrafo e sua invenção data de 1895. As primeiras projeções puderam ser vistas por multidões em diversos lugares do mundo quase ao mesmo tempo - França, Itália, Alemanha e América. Até porque a descoberta desse sistema estava prestes a acontecer para mais de um inventor. Sendo assim, a invenção destes aparelhos aconteceu praticamente ao mesmo tempo em mais de um país, sendo difícil precisar quem a efetuou primeiro.

Os irmãos Auguste e Louis Lumière são os mais popularmente reconhecidos pelo titulo. Eram engenhosos "homens da indústria", registravam fatos reais e cotidianos da sociedade (como uma famosa cena de saída da fábrica). Mas eram também mais técnicos do que artistas. O cinema, diante disso, precisava de quem lançasse sobre ele outra visão e encontrou em Georges Mélièt, um "homem do teatro" que pôde fundar um "cinema espetáculo". Trilhando um "caminho teatral espetacular", contou histórias lúdicas repletas de efeitos visuais que enchiam os olhos do público da época, maravilhado com tal ilusionismo. Mélièt soube como explorar os recursos da nova tecnologia proporcionando imagens mais impactantes que as proporcionadas pelo teatro.

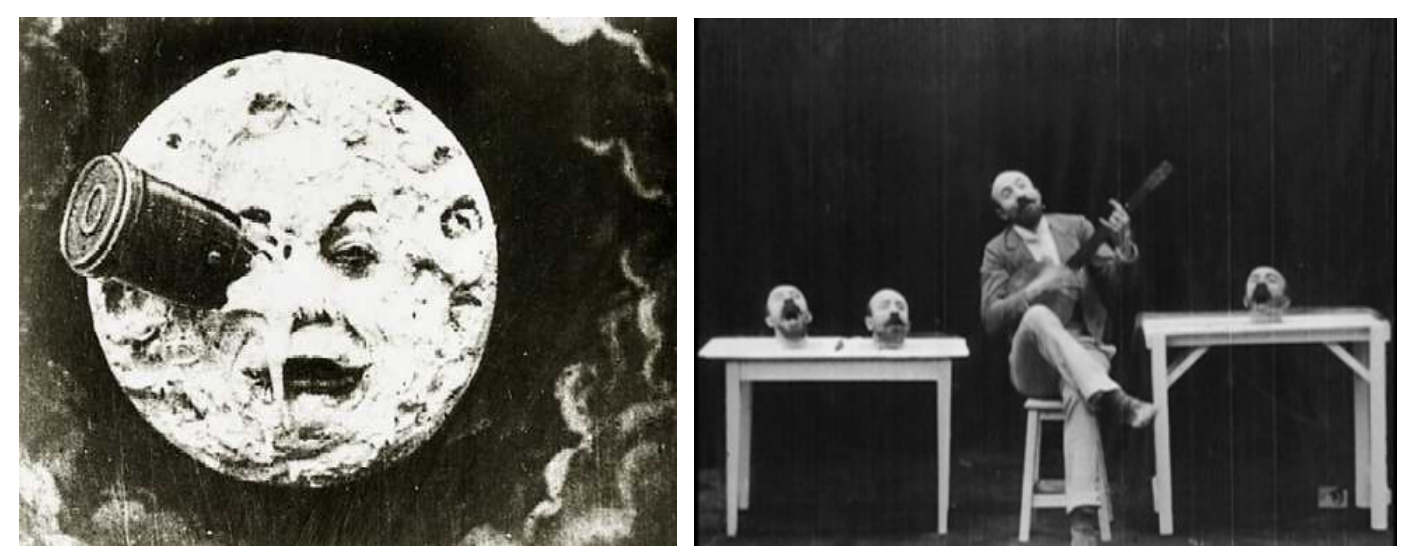

Imagem 1 Famoso fotograma extraído do filme Viagem à Lua

Imagem 2 Georges Mélièt acompanhando suas três cabeças com um banjo 
A maior parte da produção do cinema italiano voltou-se tradicionalmente para o espetáculo, principalmente nos primórdios de sua história. O setor cinematográfico começava a representar um valor econômico significativo e a construir sua importância cultural para o país.

Poucos sabem que o empreendedor italiano Filoteo Alberini (1865-1937) conseguiu, um ano antes, em 1894, o mesmo resultado que os irmãos Lumière alcançaram na França em 1895. Desenvolveu, usou e aprovou o cinematógrafo, antes da conhecida filmagem da saída dos operários da fábrica feita pelos franceses.

Alberini foi um homem verdadeiramente apaixonado pelo cinema, responsável pela abertura da primeira sala de projeção cinematográfica em Florença, 1899; pela fundação da primeira produtora, Cines, em Roma, em 1905; pelo roteiro e direção do filme La presa di Roma (1905) o primeiro a ter enredo, e por uma série de invenções mecânicas ${ }^{3}$.

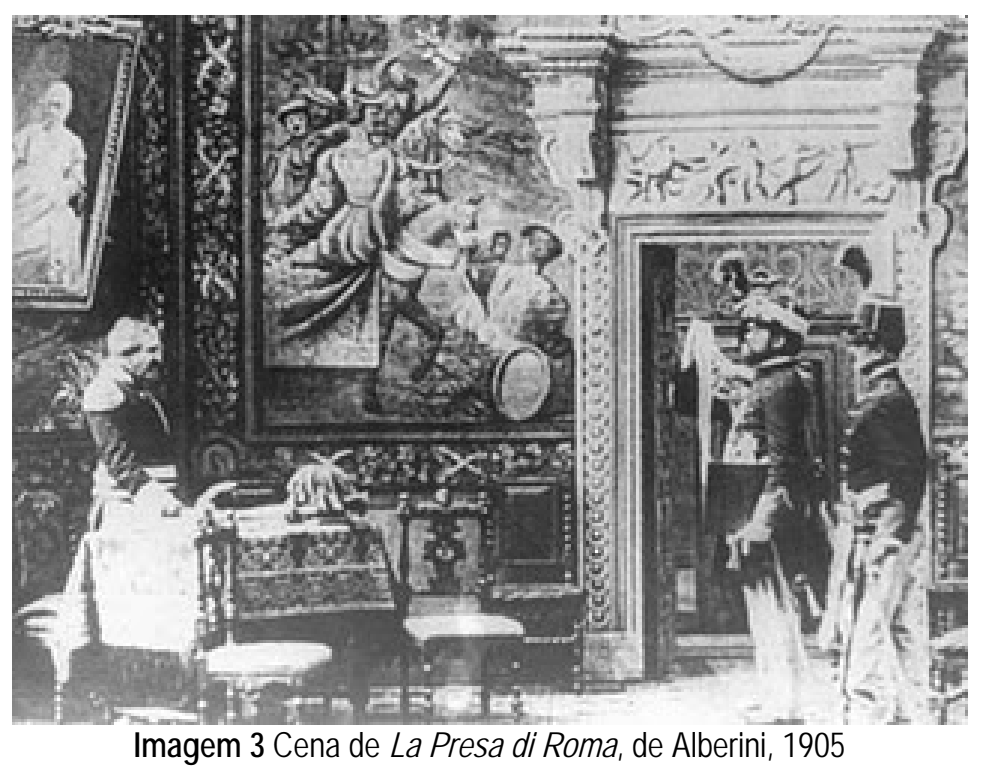

A alta competitividade com a Société Lumière dificultava o crescimento do cinema italiano que por persistência em 1905 já crescia rapidamente, explorando temas épicos, comédias e melodramas de larga aceitação popular, competindo com o mercado dos EUA e França.

\footnotetext{
${ }^{3}$ Citação do livro: LOMBARDI, Giovana. Filoteo Alberini L'Inventore Del Cinema. Bella (Potenza): Ed. Arduino Sacco, 2008, no site: http://findarticles.com/p/articles/mi_7502/is_200905/ai_n39234518/, acessado em 24 de fevereiro de 2010.
} 
Mas o pioneirismo do cinema italiano vai além de Alberini e é necessário que se lembre de mais algumas outras obras e cineastas. De 1910 a 1914, período áureo do cinema italiano, destaca-se Gli ultimi giorni di Pompei, de Mario Caserini e Eleuterio Rodolfi (1913) e atinge o clímax com Cabíria (1914), filme roteirizado, produzido e dirigido por Giovani Pastrone, jovem de apenas 30 anos (prodígio diretor da Ítala Film desde os 25 anos), elevando o cinema italiano ao prestígio internacional.
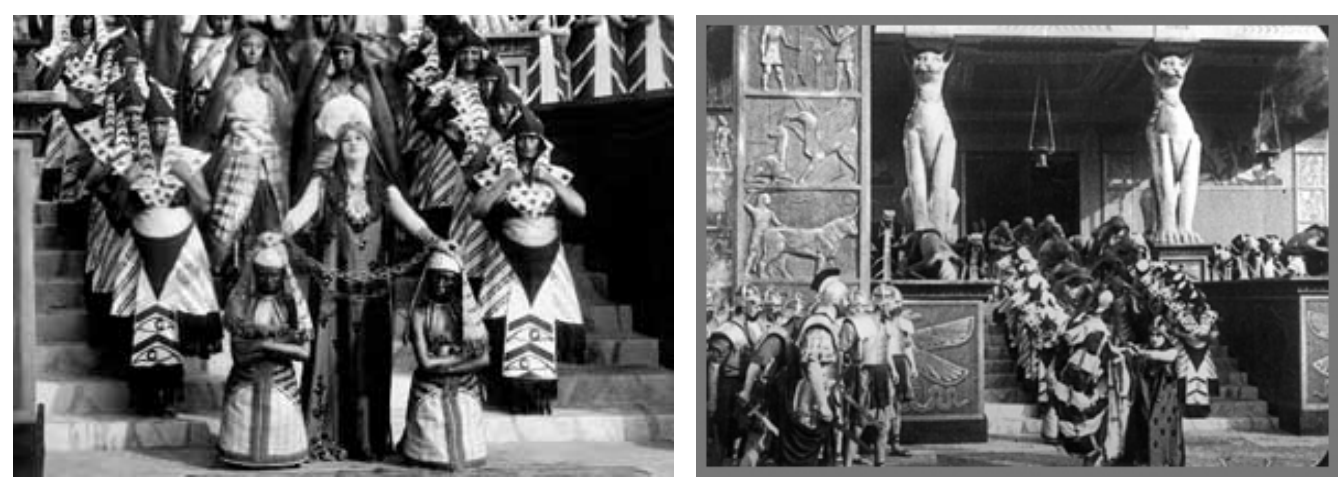

Imagens 4 e 5 Cenários grandiosos de Cabiria, 1914 - os primeiros construídos do cinema
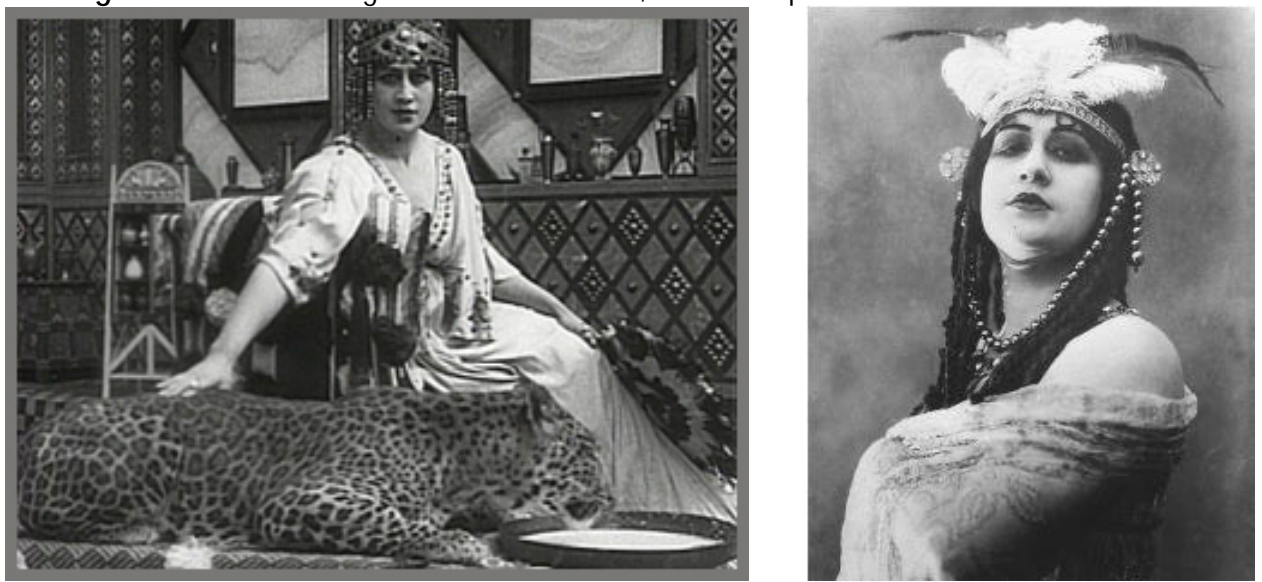

Imagens 6 e 7 A atriz Itália Almirante-Manzini que interpretou Sophonisba vestindo alguns de seus figurinos

Este longa-metragem resultou num ousado espetáculo até então nunca visto. Tornou-se referência para Federico Fellini e foi também muito admirado por Martin Scorsese ${ }^{4}$. Influenciou fortemente toda a história do cinema, inclusive o pioneiro do cinema norte-americano, David W. Grifith. Ele chegou a comprar uma cópia, à qual assistiu muitas vezes para se apoderar de vários

\footnotetext{
4 "Ele lembra de quando assistiu à obra pela primeira vez: "Não estava preparado para o escopo inusitado e para a beleza deste filme. Também não estava preparado para mudar a minha própria noção da história do cinema. Há tantos elementos que consideramos como invenções americanas, como o épico histórico de longa duração, a câmera em movimento e a luz difusa. De repente, encontramos tudo isso neste filme, realizado dois anos antes de $O$ Nascimento de uma Nação, de D. W. Griffith!" trecho extraído de Apresentação Especial Cabíria (1914) Itália, do site: http://www.mostra.org/32/exib filme arquivo.php?ano=30\&filme=6148, acessado em 24 de fevereiro de 2010.
} 
truques que bem soube utilizar em O Nascimento de uma Nação (1915) e Intolerância (1916).

As inovações trazidas por Cabiria se devem também à inquietude criativa de Pastrone, que escrevia argumentos, descobria os atores ele mesmo, desenhava os figurinos e os cenários, já havia tentado fazer filmes com bonecos, além de inventar trucagens e manipular a mecânica das câmeras para aprimorar seu funcionamento. Seu filme inovou ao construir, pela primeira vez, cenários para cinema (e eram gigantescos!), os quais foram minuciosamente decorados; a invenção e patente do carrello, hoje mais conhecido como travelling, recurso que permite ao espectador ter a sensação de invadir a cena e participar dos acontecimentos.

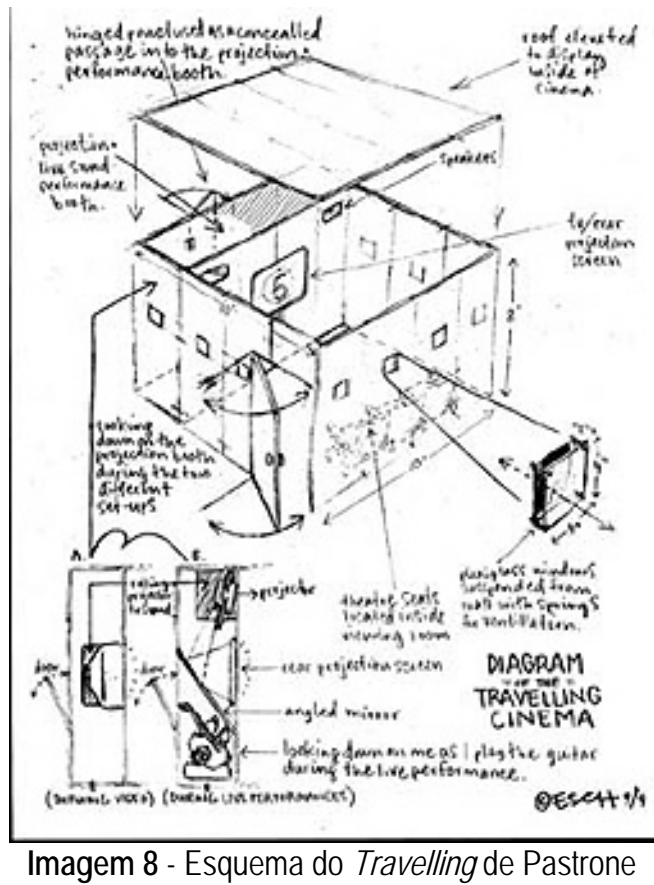

Também fez uso da luz elétrica pela primeira vez, assim como de rebatimento por meio de folhas metálicas (as que eram usadas para embalar as películas) permitindo uma luz difusa e preenchimento diferenciado sobre cenário, que possibilitou, por sua vez, a profundidade de campo nos enquadramentos. Ainda a respeito da iluminação, Cabiria também foi o primeiro filme a usá-la de maneira poética, importando-se mais com os valores dramáticos da construção plástica do que com realismo. Assim, pode-se ver uma iluminação muitas vezes não-natural (rostos iluminados de baixo para cima, por exemplo) o que teria influenciado o cinema expressionista alemão (não este filme isoladamente, mas o cinema italiano desta época). 
Inaugurou o uso do fade out na narrativa, e a montagem paralela foi outro mérito desta obra. O diretor utilizou mais de 66.000 pés de película nas filmagens, mas constam da edição original apenas 14.800 pés - o que demonstra a existência e a importância do trabalho de montagem num processo de criação cinematográfica, e que demorou cerca de um ano para se realizar ${ }^{5}$. Sabe-se que a montagem, a partir de então, é o recurso que mais se explora e diversifica, principalmente com o desenvolvimento do cinema russo da década de 20, na figura do cineasta Serguei Eisenstein.

O tempo de produção desta película, que levou dois anos para ser concluída, revela o detalhismo e o esmero de Pastrone e mais uma vez uma diferença - os filmes até então demoravam cerca de dois meses para se realizarem. Também de modo inédito percorreu longas distâncias com sua equipe e figuração - ao todo foram diversos locais da Itália, além da Espanha, Suíça e Egito, e contou com cerca de 6 mil figurantes.

O enorme sucesso internacional do cinema italiano alcançado com Cabiria só foi interrompido por causa da I Guerra Mundial, que atravancou a exportação de películas aos mercados mais lucrativos, que agora estavam preocupados com questões relacionadas à guerra.

Enquanto isso, nos Estados Unidos havia dois grandes grupos que disputavam poder e prestígio na indústria cinematográfica. O mais poderoso deles, o Trust, produzia filmes de curta-metragem pouco interessantes, enquanto o outro, o dos Independentes, menos imponente, que queria produzir um filme de autor (por isso o nome, independente) havia se refugiado no Oeste do país em Los Angeles (Hollywood) para se manter. Este último, tendo comprado a película de Cabíria, começou a produzir filmes de longa-metragem de acordo com a gramática do "grande filme" estabelecida pelos italianos, e conquistaram definitivamente o público e a hegemonia cinematográfica. Assim, ao término da Guerra, já dominavam o mercado das películas e a competitividade se tornou desleal. (BACHY, CLAUDE, TAUFOUR, 1982, p.14)

Porém, a meta de agradar ao público, que por um lado lotou as salas e disseminou o cinema pelo mundo, aos poucos dificultou que houvesse espaço para a experimentação estética, também desejada no cinema enquanto arte.

\footnotetext{
${ }^{5}$ Revista Cinema Italiano do Festival "História do Cinema Italiano - Cinemateca, São Paulo, agosto a novembro de 1960. p. 16
} 
Se retomarmos os primórdios e nos lembrarmos da dicotomia Lumière / Mélièt, podemos apontar duas vertentes marcantes desde o nascimento do cinema - 0 documentário e a ficção - o que registra ou representa a realidade tal qual ela é e o que representa a realidade pelo viés da imaginação, da sensação, da emoção.

No caso da pintura do início do século XX, com a existência do recurso fotográfico, os pintores passaram a se questionar sobre a necessidade da reprodução realista em suas telas. As vanguardas artísticas libertaram-se da obrigação de representar o mundo exatamente como nossos olhos o vêem, para poder se dedicar a representar algo mais - algo invisível aos olhos, mas tocante ao espírito.

Os movimentos artísticos do século $\mathrm{XX}$ revolucionaram as artes plásticas e, alguns cineastas de pensamento mais visual, acompanharam estes questionamentos. Afinal, documentar cruamente nossa realidade seria suficiente para expressar tudo o que desejamos expressar? O cinema serviria apenas para documentar uma época? Seria mais nobre esta visão?

O conceituado crítico de cinema, André Bazin, se manifesta, de certa forma, contrário a um cinema muito estético como foi o expressionista alemão, acusando-o de artificial e herético. Mas, por outro lado, não deixa de dar valor à ciência estética de Eisenstein.

Tanto o real como o imaginário pertencem, em arte, apenas ao artista, a carne e o sangue da realidade não são mais fáceis de caírem nas malhas da literatura ou do cinema do que as fantasias mais gratuitas da imaginação. Em outras palavras, quando a invenção e a complexidade das formas não recaem sobre o próprio conteúdo da obra, elas não deixam por isso de se exercer sobre a eficácia dos meios. Foi por tê-lo esquecido um pouco demais que o cinema soviético passou 20 anos do primeiro para o último lugar das grandes produções nacionais. Se o Encouraçado Potemkim pôde subverter o cinema, não foi apenas por causa de sua mensagem política, tampouco por ter substituído o staff dos estúdios pelos cenários reais e a estrela pela multidão anônima, mas porque Eisenstein era o maior teórico da montagem de seu tempo, porque ele trabalhava 
com Tissé, o melhor operador do mundo, porque a Rússia era o centro do pensamento cinematográfico, em uma palavra, porque os filmes "realistas" que ele produzia continham mais ciência estética que os cenários, as iluminações e a interpretação das obras mais artificiais do expressionismo alemão. (BAZIN, 1991, p. 243)

Seria possível afirmar que no expressionismo alemão a estética criada se sobrepunha ao conteúdo da obra? Como um artificialismo gratuito e ruidoso? Bazin continua:

Em primeiro lugar, é preciso ver onde fica o cinema hoje em relação a isso. Desde o fim da heresia expressionista e principalmente desde o cinema falado, podemos considerar que o cinema tendeu continuamente para o realismo. Entendamos grosso modo que ele quer dar ao espectador uma ilusão tão perfeita quanto possível da realidade, compatível com as exigências lógicas do relato cinematográfico e com os limites atuais da técnica. Com isso, o cinema opõe-se claramente à poesia, à pintura, ao teatro para se aproximar cada vez mais do romance. (IDEM)

Eisenstein por diversas vezes comparou seu ofício de elaboração da imagem ao de um pintor (remeto ao livro $O$ Sentido do Filme, mais especificamente ao capítulo O Significado da Cor). Reclamou para si, enquanto cineasta, o uso mais livre das cores e das formas, como acontece nas artes plásticas, pois em ambos os casos, tem-se como objetivo a expressividade da imagem, a conferência de um grau mais elevado de dramaticidade à cena. A ampliação que Eisenstein faz do conceito de montagem (quando se refere à montagem interior), estendendo-a aos elementos que compõe o quadro, e não apenas à concatenação seqüencial de quadros, já se faz análoga à composição pictórica.

Toda estética escolhe forçosamente entre o que vale ser salvo, perdido e recusado, mas quando se propõe 
essencialmente, como faz o cinema, a criar a ilusão do real, tal escolha constitui sua contradição fundamental, a um só tempo inaceitável e necessária. Necessária, já que a arte só existe através dessa escolha. Sem ela, supondo que o cinema total fosse desde hoje tecnicamente possível, retornaríamos pura e simplesmente à realidade. Inaceitável, já que ela se faz em definitivo às custas dessa realidade que o cinema se propõe a restituir integralmente. (IDEM).

O cinema precisa se propor a "restituir a realidade integralmente"? Não há desde os primórdios de sua criação espaço também para o cinema que conta suas histórias com imaginação?

A verdade é que o expressionismo alemão e algumas outras (poucas) experiências estéticas cinematográficas influenciaram bastante importantes cineastas ao longo da história, assim como outras formas de artes, plásticas e gráficas. Fellini é um bom exemplo disso, resultando numa cineasta absolutamente expressivo e criativo na representação de idéias por meio de imagens. Há outros cineastas influenciados por estas linguagens, como será discutido no capítulo final. 


\section{Cinema italiano e Neo-realismo}

O neo-realismo italiano surgiu na Itália e foi um dos mais importantes movimentos cinematográficos após a segunda grande guerra mundial. Não se sabe dizer ao certo a data de seu surgimento, mas é sabido que foi influenciado pelo cinema francês e que, já desde os anos 40 , eram dados os primeiros passos em sua direção. O próprio nome "neo-realismo" foi inventado pelo crítico Umberto Barbaro quando comentava o filme Ossessione (1943), de Visconti.

Pode-se pensar em alguns filmes à medida que vamos entendendo as especificidades desse modo de fazer cinema, que busca o máximo de realismo em sua realização. O filme La Nave Bianca (1941) de Rossellini, ainda sob orientação de Francesco De Robertis, eliminara todos os atores profissionais de seu elenco e apontava essa tendência.

Mas foi com Roma Città Aperta (1945), sob a direção de Rossellini que o marco desta escola se consolidou oficialmente e relançou o cinema italiano a todo o mundo. $\mathrm{O}$ argumento, que foi escrito em conjunto por Rossellini, Sérgio Amidei e Federico Fellini, teve grande influência dos relatos de um chefe da Resistência descrevendo o dia-a-dia dos combates da guerra. Para aumentar o grau de realidade, as cenas se passavam nos próprios locais da ação, descritos nestes relatos ${ }^{6}$.

Já em Paisà (1946), Rossellini radicalizou um pouco mais. As cenas foram extraídas de entrevistas feitas pelo diretor e seus colaboradores (incluindo Fellini) com pessoas diversas, desde soldados e figuras eclesiásticas, a gente do povo. Estas cenas foram depois encenadas por estas mesmas pessoas nos locais referidos. Mais uma vez, não havia atores, nem figurinos ou cenários concebidos, nem muito menos um trabalho controlado em estúdio.

Muitos outros filmes foram feitos em 46, seguindo a mesma linha, quando o neo-realismo completava um ano de seu nascimento. A princípio os filmes considerados neo-realistas eram aqueles que se ocupavam de temáticas relacionadas à guerra e suas conseqüências, mas depois também foram sendo 
considerados os filmes que tivessem cunho social ou se estabelecessem em locais de pobreza (SADOUL, 1983).

Para se manter vivo, o neo-realismo que tentava se expandir ampliando suas características, começou a perder um pouco sua identidade. E, por outro lado, quando tentou rebater e fixar essa identidade por sua atualidade social e pelo estudo da sociedade italiana no imediato pós-guerra, o movimento ficou limitado no espaço e no tempo. Sendo assim, ainda que restem traços esparsos deste modo de fazer cinema ao longo da história, o neo-realismo se extinguiu por volta de 1953. 


\section{Federico Fellini e o Neo-realismo Italiano}

Como já citado, Fellini fez parte do núcleo original do neo-realismo italiano, uma vez que foi colaborador de Rossellini em dois dos primeiros grandes filmes deste movimento (Roma Città Aperta e Paisà), senão os mais emblemáticos.

Mas Fellini seguiu com um tipo de cinema autoral, muito diferente do cinema neo-realista praticado por seus antecessores. Fellini transfigurou a realidade pela poesia. E pode-se dizer que se manteve integralmente fiel à sua poesia e suas constantes, sobre as quais falaremos logo mais.

Por este motivo, alguns críticos não incluíram seu nome entre os neorealistas, e outros, como Zavatini, que se lembravam dessa sua passagem pelo movimento, o chamaram de "desertor".

La Strada (1954), um dos filmes em questão nesta dissertação e que está entre os primeiros trabalhos do diretor, é o filme que completa essa transfiguração do neo-realismo pela poesia elaborada por Fellini, ou, pode-se dizer que ele trabalha o real de modo espetacular. E muitos são os argumentos que o libertam do rótulo neo-realista.

Se analisarmos o enquadramento espaço-temporal da obra, observaremos que a fábula de La Strada não está fortemente enraizada na história, como costuma acontecer com os filmes neo-realistas. Isto a desloca, portanto, do padrão ortodoxo esperado para o movimento, de preocupar-se sobretudo com a temática do pós-guerra, por exemplo. Fellini declara com este filme sua ruptura com as preocupações neo-realistas e declara sua preferência por uma interpretação mais a-histórica da condição humana ${ }^{7}$.

Sobre os personagens de La Strada pode-se ver que nem Gelsomina nem Zampanò traçam o mesmo tipo de jornada percorrida pelos personagens de tipo mais social, como são Antônio e Bruno de Ladrões de Bicicleta, os quais passam pelas grandes instituições do país e verificam-nas deficientes,

\footnotetext{
${ }^{7}$ Marcus Millicent afirma sobre a jornada de Gelsomina e Zampanò: "That this is not a standard neorealistic journey, such as the one in Paisan, or The Path of Hope, is proved by the total absence of concrete spatial and temporal markers to root the story in history. (...) Unbound in time and space, Fellini's story thus announces its departure from neorealist historicity and its preference for an ahistorical rendering of the human condition" (MARCUS, 1986, p. 148 e 149).
} 
insuficientes. Fellini não passa por essas grandes instituições, evita-as, buscando o interior, os pequenos centros e subúrbios.

As únicas grandes instituições emblemáticas abordadas por Fellini em La Strada são a Igreja e a família. Mas a Igreja aparece mais para reforçar o impacto do espetáculo na alma de Gelsomina (na cena da procissão) e para fazer uma analogia entre a sua falta de auto-confiança (ao confiar seu destino a Zampanò) e a subserviência religiosa da freira a Deus (no diálogo com a freira a quem os artistas ambulantes dão uma carona ao convento): "You follow your bridegroom, I follow mine" - "Você segue seu noivo, eu sigo o meu".

E quando aborda-se a família, esta serve menos como um objeto de crítica social do que como comentário sobre a marginalidade de Gelsomina. Seu personagem não se insere em nenhum daqueles papéis familiares, mantém-se à margem, ou sozinha dançando, ou entre as crianças (aqueles que ainda não cresceram, não conquistaram seu lugar no mundo, os que não têm poder de escolha).

Em vez da despreocupação com atores profissionais, tão própria do neo-realismo ${ }^{8}$, temos neste filme três grandes atores - Giulietta Masina, Anthony Quinn e Richard Basehart. A atuação de todos foi da máxima importância para o sucesso alcançado. E a escolha do elenco, feita "a dedo", foi fundamental não apenas pela extrema desenvoltura dos atores, mas pela correspondência dos seus tipos físicos e fisionomias aos desenhos criados pelo diretor quando começava a imaginar o roteiro desta obra.

Tal correspondência não era um mero capricho, mas uma questão de chegar à impressão mais exata de cada um desses personagens e de cada idéia representada por eles. Logo, podemos imaginar o quanto a caracterização, a concepção do figurino (desprezados pelos neo-realistas) foram importantes para a realização deste filme, para que esta história fosse contada como uma obra poética e como um filme de personagem.

Os figurinos que estes três personagens usam nas apresentações são apenas versões mais exageradas dos seus trajes cotidianos, usados ao longo

\footnotetext{
${ }^{8}$ Segundo o crítico Diogo Arocena, são neo-realistas "aqueles filmes que tomam seu assunto da vida diária da Itália de após-guerra, trabalham quase exclusivamente fora do estúdio e com atores não profissionais para assim obter um alto grau de autenticidade. In Revista Cinema Italiano do Festival "História do Cinema Italiano" - Cinemateca Brasileira, São Paulo, agosto a novembro de 1960. p. 50.
} 
do filme. Justamente porque todos os figurinos foram concebidos pensando em colaborar com a idéia da construção desses personagens. Fellini pressentia, como confirma o teórico Jean Mitry em seu livro sobre estética e psicologia no cinema, citado por Betton (1987, p. 52), que "o espectador é sempre atraído, numa imagem, por aquilo que atinge, plástica ou dramaticamente, o máximo em significação".

Diferente de Rossellini e De Sica, Fellini se volta aos moldes do drama popular e à mímica para criar o modelo de seu filme. O empréstimo mais evidente vem da tradição da comedia dell'arte, por meio dos figurinos e dos papéis estilizados, que nos faz rapidamente identificá-los. II Matto pertence à família de Arlequim, com seu figurino heterogêneo, humor, refinamento e habilidade acrobática. Zampanò, por outro lado, é descendente de Pulcinella, com sua falta de graça. Quando quer que eles se encontrem, acontece alguma briga, algum atrito, que faz parte da rotina destes personagens na comedia dell'arte.

Por todos estes motivos, ao se diferenciar dos realizadores neo-realistas com La Strada, Fellini provocou espantosa polêmica na Itália, entre críticos e cineastas, sendo acusado de "desviar-se da realidade para refugiar-se no sonho". Ainda que, a esse tempo, o neo-realismo já houvesse concluído seu papel histórico a mais de um ano ${ }^{9}$. Para encerrar de vez a questão, Fellini finalmente se pronunciou, citando apenas Zavattini, o mais conhecido dentre os que o atacaram. Assumiu sua diversidade de vivência e manteve-se alheio a tendências pré concebidas:

Penso que não se deve considerar a realidade como um panorama de uma só superfície, que essa paisagem tem diversas espessuras e que a mais profunda, aquela que só uma linguagem poética pode revelar, não é a menos real. É esta que desejo mostrar abaixo da epiderme das coisas e das pessoas taxadas de irreais. Fala-se da atração pelo mistério. Aceitaria esse termo se fosse escrito com $\mathrm{M}$ maiúsculo.

\footnotetext{
${ }^{9}$ Conforme o teórico e cineasta Luigi Chiarini, "o neo-realismo não se poderia definir pelo estilo, muito variável segundo os realizadores, mas por sua orientação no sentido da atualidade social e do estudo do povo italiano no curso do imediato após-guerra", o que limitaria o neo-realismo social e temporalmente. In Revista Cinema Italiano do Festival "História do Cinema Italiano" Cinemateca Brasileira, São Paulo, agosto a novembro de 1960.
} 
Quando Zavattini diz Mistério, ele pensa em sucedâneo poético no qual salpico a realidade, no qual altero a verdadeira face das coisas. Para mim o mistério é aquele do homem, as grandes linhas irracionais de sua vida espiritual, o Amor, a Salvação, a Redenção, a Encarnação. No centro das espessuras sucessivas da realidade se encontra para mim Deus, a chave dos mistérios.

Acho que sou tão ou mais neo-realista do que os neo-realistas dogmáticos. Rossellini dirigindo Roma Città Aperta, não sabia que estava fazendo neo-realismo. Depois, construíram um muro em torno do neo-realismo. Agora, surpreendem-se e gritam porque Rossellini e eu saltamos por cima do muro.

Zampanò e Gelsomina não são exceções. Ainda há mais Zampanòs no mundo do que "ladrões de bicicleta", e a história de um homem que descobre seu próximo é tão importante, tão real quanto a história de uma greve.

O que nos separa é sem dúvida uma visão materialista ou espiritual do mundo..."10

${ }^{10}$ Fellini in Revista Cinema Italiano do Festival "História do Cinema Italiano" - Cinemateca Brasileira, São Paulo, agosto a novembro de 1960. 


\section{Federico Fellini - Vida e Obra}

Federico Fellini nasceu em março de 1920, na pequena cidade italiana de Rimini. Era o filho mais velho do casal, Urbano e Ida, ele, vendedor ambulante em Savignano e ela, dona de casa. Seus irmãos eram pouco mais novos - Riccardo, que mais tarde participaria de um de seus filmes (II Vitelloni, de 1953), e Maddalena.

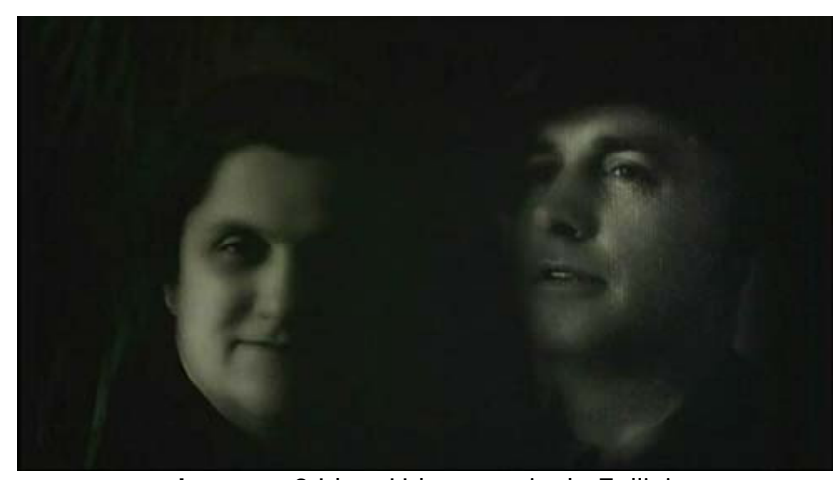

Imagem 9 Ida e Urbano, pais de Fellini

Quando menino, Federico foi acometido por um problema de tireóide que o deixou bastante magro e o fez sentir constrangido e tímido no meio dos outros meninos de sua idade. Esse fato só veio agravar a sensação que já possuía, mesmo em família, de ser diferente dos demais.

Foi esta mesma sensação que o fez refugiar-se em sua imaginação desde cedo. Quando todos os meninos iam à praia - um dos lugares mais venerados por ele desde a infância - ele ficava ressentido, mas sempre se recusava a ir por vergonha de vestir o calção. Incentivado por sua mãe, que gostava de desenhar e o ensinou a usar os lápis e canetas, preenchia este vazio com desenhos, atividade de que gostava muito e o deixava bastante orgulhoso. Além de desenhar, assim como o diretor Ingmar Bergman, ele também construía marionetes quando era pequeno, o que foi uma maneira de aprimorar sua sensibilidade dramática para construir seus personagens. (BORIN e MELE, 1999)

Esse gosto pelas imagens combina com seu gosto pelos espetáculos, pela fantasia e por contar histórias visualmente. Em suas entrevistas desfilam um sem número de personagens e de acontecimentos de sua infância: há loucos, moradores de rua, camponeses, famílias... cenas muito vivas, que conseguimos enxergar como se nos passasse um filme. Entre os principais 
acontecimentos, está a chegada do circo a Rimini, mais tarde recontada em alguns de seus filmes, como Roma, Amarcord e I Clowns uma das experiências que nunca saíram de sua memória.

Mas junto àquele prazer por desenhar, veio a paixão também pelas histórias em quadrinhos, que o influenciaram durante toda a carreira, tanto como cartunista, quanto como diretor cinematográfico. Fellini lia quadrinhos mais até do que ia ao cinema; primeiro os americanos como Bringing Up Father, Felix, The Cat e Happy Hooligan e mais tarde os famosos de Will Eisner, entre outros.

Assim que saiu com o diploma da escola, em 1937, abriu com o colega, Demos Bonini, um pequeno estúdio artístico chamado FEBO, em que fazia caricaturas e retratos, inclusive em domicílio. Ele fazia os desenhos e o amigo os coloria. Na mesma época, em troca de entradas grátis para ver filmes, Fellini fazia caricaturas de atores contemporâneos (imitando o traço de um cartunista italiano famoso, Nino Za) para ficarem expostas nas lojas ao lado da programação do cinema.

Desenvolvido cada vez mais seu talento como cartunista, ainda no mesmo ano, Fellini foi para Florença e começou a trabalhar. Tinha então dezesseis anos e vendia histórias em quadrinhos e diálogos humorísticos para a 420, a única revista satírica da Itália.

Mas como ganhava muito pouco, após três meses, mudou-se para Roma. Era o ano de 1938 e sua mãe esperava que o filho entrasse para a Faculdade de Direito. Fellini encantou-se com a cidade, tanto que morou por lá durante os próximos 50 anos seguintes, mas não atendeu a vontade da mãe.

Começou a trabalhar como secretário na Il Popolo di Roma, onde abria correspondências e fazia recados. Escrevia crônicas, textos publicitários, argumentos, desenhava histórias em quadrinhos e os vendia à Marc'Aurélio e outras revistas, o que durou três anos. Seu trabalho na Marc'Aurélio, como escritor e ilustrador, contribuiu para que estabelecesse raízes em Roma, especialmente no mundo do cinema. Como jornalista entrevistou atores e diretores. Trabalhou também em rádio escrevendo radionovelas, época em que pôde conhecer muitos outros atores, incluindo Giulietta Masina, com quem se casou pouco tempo depois, em 1943. Eles dividiram toda a sua vida, parte de seu trabalho, além de tanto amor e admiração. 
Depois da guerra, abriu com um amigo uma loja de caricaturas para os soldados norte-americanos chamada The Funny Face Shop. Lá, além de fazerem desenhos e caricaturas, os soldados também podiam gravar a própria voz em discos e acontecia todo o tipo de confusão. O negócio foi ótimo, pois Fellini ganhou, em proporção, mais dinheiro do que havia ganho até a data. Além disso, foi lá que Rosselini entrou um dia à procura de Fellini, a fim de conseguir o contato de um ator amigo seu, Aldo Fabrizi, com o propósito de que participasse de seu curta-metragem. O que seria apenas um curta, acabou se transformando em um longa-metragem e resultando na primeira colaboração de Fellini em um roteiro cinematográfico, dando origem ao filme, Roma Città Aperta (1945), e à amizade entre Fellini e o diretor:

Parece-me que aprendi de Rosselini (...) a possibilidade de manter meu equilíbrio nas condições mais adversas, nos conflitos e ao mesmo tempo, a natural habilidade de virar estas adversidades e conflitos a meu favor e transformá-los em sentimentos, em valores emocionais, em pontos de vista. Isto é o que Rosselini fez: ele vivia a vida de um filme, como uma aventura maravilhosa de ser vivida e simultaneamente recontada (BORIN e MELE,1999, p. 26).

\section{O universo de Fellini}

O universo de Fellini permanece um dos mais pessoais dentro do contexto da história do cinema, pelo modo como ele prepara seus filmes, pelas suas abordagens e pela riqueza de seu mundo mítico. É difícil definir o poder das imagens dos filmes de Fellini e certamente falharemos em colocá-lo dentro de códigos de qualquer cultura figurativa.

É inegável que em sua fase inicial haja uma certa dose de realismo, provocando comparações com o neo-realismo. Porém, quando se fala em neorealismo relacionando-o a Fellini, é preferível considerar apenas o modo como fez seus filmes e seu relacionamento com Rosselini. Fellini o admirava pela amizade que tinham, por ter trabalhado com ele como ator, como roteirista e como assistente. Outro motivo de admiração era o de ter despertado em Fellini 
a paixão pelo cinema - principalmente por ter lhe apresentado uma realidade do cinema, autônoma, humanística, não-ideológica e apolítica.

$\mathrm{Na}$ sua própria trajetória, elementos tais como o experimentalismo, 0 misticismo, a emoção e um gosto pela decadência, começam sendo abordados de maneira mais realista e melancólica e depois se intensificam passando a sêlo de modo mais alegórico e atemporal. Mas um ponto comum no conjunto de seus filmes é a tomada do espetáculo da decadência como um leitmotiv para detectar a deterioração da humanidade naquilo que é mais essencial entre os seres: a capacidade de comunicação.

O grande problema da falta de comunicação humana, presente em todas as suas películas, manifesta-se de forma objetiva até Noites de Cabíria (1957). Depois esse fixar-se na solidão ganhou enfoque coletivo, enquanto o onirismo servia de instrumento para uma espécie de radiografia fenomenológica da dança de desencontros do mundo interior, subjetivo, onde a memória se encarna no sonho. Assim, a vertente mais irreal, alegórica e encantatória surge, propondo a ruptura de uma sociedade envelhecida, alienada justamente por manter seus ideais tradicionais e dogmáticos.

Além da falta de comunicação, são grandes temas de Fellini também a falta de amor e a solidão, também presente em todos os seus filmes (até por serem temas derivados desta mesma falta de comunicação). Mas o diretor não é pessimista, pois podemos ver em quase todos os seus filmes um sinal de esperança e este é outro ponto comum em sua obra. Seus cenários recorrentes são as praças, o mar e a terra - esta, em muitos casos usada como elemento de purificação (como é principalmente para os personagens Zampanò e Cabíria).

No conjunto da obra de Fellini (principalmente nos filmes até 57) podemos notar certa influência do cristianismo, o que talvez seja uma herança de Roberto Rosselini. Mas provavelmente é uma herança muito mais contundente de sua infância próxima dos valores cristãos católicos e da repressiva força da Igreja Católica, na Itália do início do século XX.

Sobre estas forças repressivas, há muito o que se falar nas obras de Fellini. Afinal, havia opressão vinda por parte da Igreja e por parte do regime fascista. Sempre um medo suspenso no ar, controlando o comportamento e a opinião das pessoas, pelos dois lados. Fellini recorda: 
Uma vez, numa cerimônia quaresmal, se organizou uma vasta festa na colina, com camponeses, velhas, favas, fedor, cascas de salame e alguém que vomitava. Subiam cantando de joelhos, para chegar à última estação. Don Giovani, que ia na frente, gritava: “... e caiu pela segunda vez”. Logo, ocorrências ainda mais dramáticas, a aumentar de forma sombria, mortificante, sangrenta. Nesse momento senti medo. A religião sempre era aterrorizante. (BORIN e MELE,1999, p. 29)

Na época, somaram-se à religião os rostos dos fascistas. Um deles, que havia batido em seu pai, ele reconheceu ao lado de outros suspeitos cantando na igreja, junto com o arcipreste ${ }^{11}$.

Vem dessas lembranças, nada suaves, a presença recorrente de elementos da igreja católica em seus filmes - freiras, padres, bispos, procissões, sacrifícios, imagens de santos. Esses elementos são quase sempre satirizados $^{12}$, mas às vezes também assustadores ${ }^{13}$. Há também militares, também ironizados, explicitando de maneira clara a opinião negativa do diretor sobre qualquer tipo de força controladora do comportamento e do pensamento das pessoas.

Por isso mesmo é que Fellini, que nunca sentiu-se muito atraído pela política, via na atitude revolucionária da juventude da década de 60 (considerando maio de 68, na França, como momento emblemático) uma luta ética que valia a pena, finalmente um gesto político, que ele aplaudia.

\footnotetext{
${ }^{11}$ Arcipreste (do latim tardio archipresbyter) é o decano entre os presbíteros de um arciprestado, responsável pela correta execução dos deveres eclesiásticos e pelo estilo de vida daqueles que estão sob sua autoridade. O Arcipreste tem no Arciprestado as mesmas funções que o Vigário Forâneo tem na Vigararia. In http://pt.wikipedia.org/wiki/Arcipreste, acessado em 10 de abril de 2010.

12 Lembrar por exemplo do "desfile de moda" que acontece no filme Roma (1972) diante do Papa, só com "modelitos" para padres, bispos, cardeais e freiras - abas enormes saem da cabeça das freiras, movendo-se como se fossem asas gigantescas conforme o seu andar, cardeais com roupas coloridas imitando vitrais de igreja que piscam como uma árvore de natal, entre muitos outros exemplos hilariantes.

${ }^{13}$ Como um exemplo de impressão um pouco assustadora, pode-se citar Noites de Cabiria. No momento em que Cabíria resolve levar um vela na procissão para fazer seus pedidos e se redimir por seus pecados, (procissão que é retratada como um evento na cidade, como são as romarias em Aparecida do Norte, no Brasil), há um certo medo demasiado da punição, ainda que ela seja o personagem mais repleto de bondade, doçura e uma certa ingenuidade na busca do bem. Percebe-se também uma ironia, pois o seu pedido de redenção é em certo ponto tratado como uma "negociação", de modo que, "talvez" ela possa ser atendida, "se" ela merecer.
} 
Sentia-se inspirado a mudar também sua estética, repensar a sociedade, seus valores, motivado pela mudança de comportamento daqueles que não se deixavam mais reprimir, nem pela família, nem pelo governo, muito menos pela rançosa tradição da moral e dos bons costumes.

Se nos seus primeiros filmes, até 1957, podemos sentir a influência de Chaplin (de quem Fellini era grande admirador) na temática de procura e desencontro, no lirismo das histórias, em sua estrutura linear e mais fechada, de direção conceitual mais específica, nas obras que vêm depois, sentimos estruturas mais abertas e mais possibilidades conceituais são aceitas.

Quanto às mudanças estéticas, elas vieram e foram motivadas por toda aquela revolução cultural da época, justamente quando Fellini foi produzir seu primeiro filme em cores, Julieta dos Espíritos, em 1965. Com acompanhamento médico, Fellini chegou a fazer experiências com ácido lisérgico (LSD) a fim de pesquisar em profundidade novas possibilidades de compor com as cores nessa nova empreitada. Os resultados dessas experiências se estenderam também aos filmes seguintes, mas é principalmente em Toby Dammit, de 1968, que mais se percebe - repleto de referências psicodélicas, saturação nas cores dos cenários, às vezes também nos figurinos e na iluminação que, inclusive é irreal em muitos momentos. Nestes dois filmes, toda a composição visa, acima de tudo, a expressão de atmosferas e do mundo interior dos personagens protagonistas lidando com suas crises existenciais.

Enfim, o gosto pelo tema da decadência em Fellini, vem da percepção clara que ele tem da necessidade de mudança e abandono de antigos valores morais e cristãos, já possivelmente ultrapassados e alienantes para a sociedade contemporânea. 


\section{Um processo de trabalho}

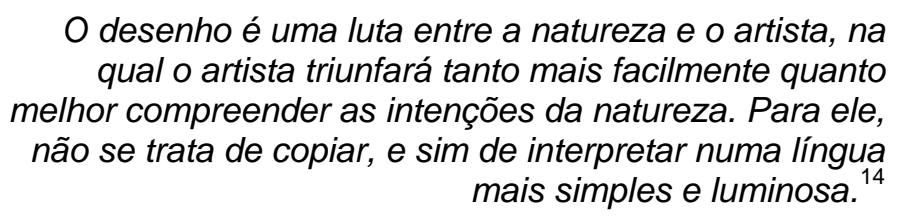

Charles Baudelaire

Concentrando-nos na paixão visceral de Federico pela prática de desenhos fantásticos e pelos esboços caricaturais, chamados carinhosamente por ele de "rabiscos", notamos o quanto esta paixão evidencia sua necessidade de traduzir suas idéias em imagens. Ele mesmo dizia que quando preparava um filme, escrevia muito pouco e preferia desenhar seus personagens e cenários (atribuía este hábito ao tempo em que trabalhou com os music halls do interior), e inclusive confessou que algumas idéias já nasciam em forma de imagem como foi o caso da personagem "Gelsomina", de La Strada. (KEEL e STRICH, 1983). Devemos, portanto, prestar atenção no quanto os desenhos faziam parte do seu processo de criação e de direção.

Rabiscar ajudava Fellini a pensar os filmes antes mesmo deles se transformarem em roteiro. Chegou a se comparar a um atleta que se aquece fazendo seus exercícios - assim, ele se aquecia, afiando suas idéias ao fazer seus desenhos, como se eles o ajudassem a ver o mundo.

Mas não desenhava como se fosse uma história em quadrinhos, imagem após imagem, pois a influência dessa arte seqüencial se manifestava apenas pelo modo estereotipado e expressivo com que ele desenhava. O núcleo fundamental do "método fellini" está no uso do desenho para a caracterização de personagens e cenas-chave. Dizia que era uma forma de entrar em sintonia com as histórias e de se apegar às criaturas que começavam a povoar sua cabeça:

Desenhar é o passo fundamental. A coisa mais difícil é encontrar o ator que se ajuste ao desenho. Eu procuro por ele ou ela até eu encontrar alguém que me faça dizer: "Você, você é o meu desenho!" Isto é provavelmente verdade para

\footnotetext{
${ }^{14}$ BAUDELAIRE, Charles. "Salão de 1846" in LICHTENSTEIN, Jacqueline (org.) O Desenho e a Cor. São Paulo: Ed. 34, 2006. (A Pintura - Vol. 9) p.105.
} 
qualquer papel, exceto para os de Giulietta. (MOLLICA, 2004, p 32)

Assim, personagens surgiam nos mais variados locais, cartões, caixas, guardanapos... à caneta, à tinta, à lápis... Ele adorava desenhar em restaurantes e fazia isso bem rápido.

Com finalidades práticas e funcionais, buscando soluções lógicas e expressivas para a mis en scène, estes "rabiscos" de Fellini não paravam durante as filmagens e ainda podiam determinar uma mudança radical no planejamento do filme - inserir uma nova cena, um novo personagem, auxiliar na composição da luz, ditar a maquiagem e o figurino, a caracterização de uma voz, ou alteração de timbre na hora da dublagem. Fellini acompanhava tudo o que era feito a fim de poder orientar seus colaboradores em todas as etapas de produção dos seus filmes.

Imagem 10 Desenho feito por Fellini para referenciar a maquiagem de Casanova (DE SANTI, 2004, fig. 145) Imagem 110 ator Donald Sutherland sendo caracterizado para interpretar o personagem Casanova

Pode-se dividir em três tipos diferentes estes desenhos de Fellini. Primeiro, os desenhos que são como memórias gráficas ou funcionam como válvula para o desenvolvimento visual das suas idéias, e que são feitos durante o processo de concepção do filme, e às vezes até enquanto o filme está sendo rodado. O segundo tipo, em que os desenhos que são feitos para servirem às páginas de trabalho e que irão orientar o trabalho dos cenógrafos e figurinistas, ou às vezes constituirão uma "mise en page" na qual frequentemente os espaços e os planos são indicados (MOLLICA, 2004). E um terceiro tipo, que funciona como um "espelho auto-interpretativo", no qual o diretor põe para fora uma diversidade de revisitações de imagens de seu próprio universo, incluindo quase sempre as mais amadas por ele. 
Pier Marco de Santi, que escreveu sobre o processo de criação de Fellini no ensaio // Disegni di Fellini (Laterza: Bari, 1982) ${ }^{15}$, reparou que ele não desenha de modos diferentes para filmes coloridos ou em preto e branco, e que também não se inspira em um pintor específico, um movimento artístico... Seus esboços têm sua "marca registrada", sempre com uma caracterização estilizada e uma veia humorística, tendendo ao grotesco surreal. Além disso, reparou também que mesmo num período superior a trinta anos de atividade, e que mesmo com as variações temáticas e de conteúdo, de narrações e ambientações de suas várias obras, o estilo dos desenhos permanece uniforme e se garante autônomo em relação ao estilo dos filmes.

O traço-assinatura de Fellini - cabeça achatada e o grande nariz de batata - que nota-se ao longo de toda a sua carreira, se firmou a partir do personagem Geppi, da tirinha Geppi, La Bimba Atômica, publicada pela revista Campanello, pouco antes de 1946.

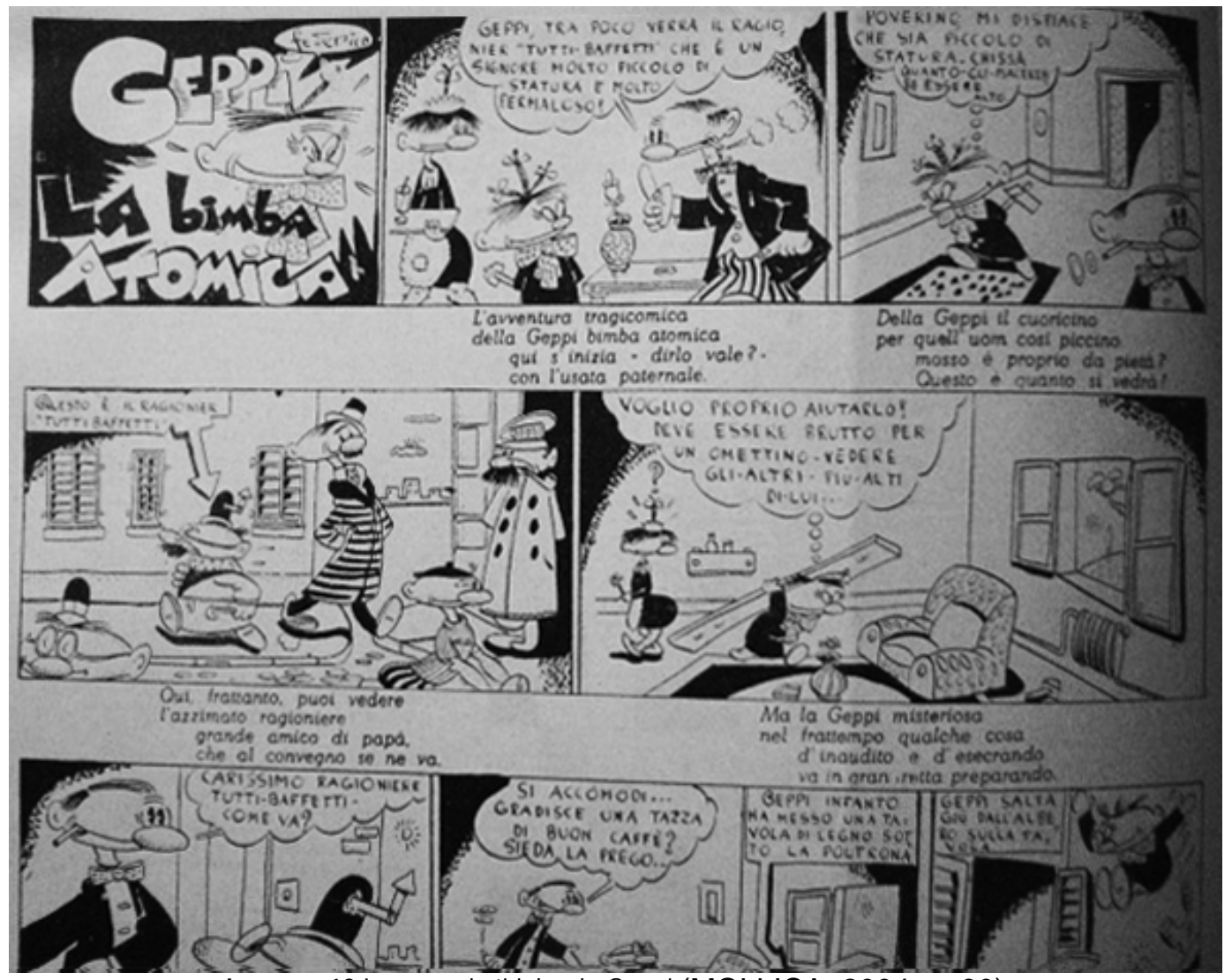

Imagem 12 Imagem da tirinha de Geppi (MOLLICA, 2004, p. 30)

\footnotetext{
${ }^{15}$ Segunda publicação de ilustrações de Fellini e primeira a aproximar estas ilustrações dos seus respectivos filmes, cronologicamente.
} 
Conciliando a relação entre cinema e pintura, Fellini fornece uma série de depoimentos que colaboram para uma visão pictórica do seu trabalho, o que ele defendia muito:

O cinema é uma arte. Eu digo isso com profunda convicção. O cinema é uma arte assim como todas as outras. Ele é uma das artes. Para mim, não é como literatura, é como pintura, porque ele é feito de quadros em movimento.

(...)

Eu acredito que para muitos diretores a palavra falada é mais importante que a imagem, e eles são diretores literários. Para mim, o filme é a "criança" da pintura. (MOLLICA, 2004. p.33)

Dentre os grandes pintores, os que Fellini mais admirava eram Pablo Picasso (com quem se identificava muito e com chegou a ter sonhos bastante simbólicos), Vincent Van Gogh, Henri Matisse, Toulouse-Lautrec e Balthus. Entre os pintores italianos, gostava de Scipione, Mafai, Rosai, Campigli, Carrà, Sironi e De Chirico. Entre os desenhistas, Fellini admirava Charles Schulz, o criador de Snoopy, Lee Falk, o criador de Mandrake (personagem usado por Fellini em Intervista) e Milo Manara, por quem além de admiração, nutria verdadeira amizade. Manara chegou inclusive a transformar em quadrinhos (ou graphic novels) dois roteiros do diretor - incluindo II Viagio de G. Mastorna, o filme não concluído de Fellini.

A estilização, o traço autoral, como representação do que se sente e não do que se vê, era algo buscado por Fellini e admirado por ele em outros artistas:

Eu não estou interessado na vida real. Eu gosto de observar a vida, mas eu não posso deixar minha imaginação ser, acima de tudo, afetada por isso. Desde que eu era criança, quando eu desenhava uma pessoa, eu as desenhava de acordo com a imagem que eu tinha delas em minha mente, não como elas realmente eram. (MOLLICA, 2004. p 32) 
Pier Marco De Santi, também percebeu que a cor nos desenhos do diretor não é um mero acessório para a sua pintura gráfica, é uma necessidade expressiva. Daniela Barbiani, sobrinha e uma de suas assistentes de direção, revelou em depoimento que se, por um lado, Fellini desenhava muito rápido e em qualquer suporte, poderia levar muito mais tempo para colorir: "Ele tinha que encontrar a sombra certa, a cor certa, porque cada uma dessas cores expressava um sentimento específico. E nestes desenhos, assim como em seus filmes, luz e cor desempenham um papel dominante, porque luz - como diria Fellini - é estilo." 


\section{O Aspecto Plástico - nas Artes e no Cinema}

Todas as artes da visão nasceram juntas e diretamente do desenho ${ }^{16}$

Giorgio Vasari

Muitos são os recursos plásticos de que o cinema pode lançar mão para contar uma história e registrar uma idéia, uma impressão. Abordarei neste tópico alguns desses recursos, para que possamos entender o quanto Fellini foi profundo na utilização dessas ferramentas registrando suas idéias e emoções. E para que possamos entender como ele ousou na utilização habitual que era feita desses recursos até então.

Como já afirmara o teórico de cinema, Jean Mitry, reforçando a importância de uma imagem bem construída, o espectador é sempre atraído numa imagem por algo que atinge, plástica ou dramaticamente, o máximo em significação. E para a composição desta imagem há tendências diferentes que se pode seguir (influenciando na composição do cenário, do figurino, da maquiagem, da iluminação, do roteiro, etc). Tendências mais realistas, impressionistas ou expressionistas, dependendo muito do que se quer priorizar. Em linhas gerais, pode-se escolher entre uma visão mais objetiva ou mais subjetiva do mundo; uma representação mais documental ou mais deformada pela interioridade das coisas, estilizada, simbólica.

Uma luta constante entre essas diferentes linhas é travada desde os primórdios do cinema. A que parece ter prevalecido em sua história é a realista, como podemos perceber pela grande e esmagadora maioria dos filmes que conhecemos e que seguimos vendo estrear nos cinemas. Mas, se estamos falando de uma arte, ela possui um campo de criação poético, estético - então por que seguir unicamente reconstituindo a realidade como já a conhecemos?

O teórico de cinema Gerard Betton, chega a comparar o filme a um poema, a uma "arquitetura em movimento", "uma música que nos atinge por intermédio dos olhos", uma criação pictural, uma dança. O cinema é a arte da "ordem e da proporção no espaço e no tempo", o que implica em uma montagem criativa e plenamente consciente. Montagem esta, que se refere não

\footnotetext{
${ }^{16}$ VASARI, Giorgio. "A vida dos mais excelentes pintores, escultores e arquitetos", in LICHTENSTEIN, Jacqueline (org.) O Desenho e a Cor. São Paulo: Ed. 34, 2006. (A Pintura Vol. 9). p.19.
} 
só ao ato de colocar em sequência os planos filmados, mas à escolha de cada um dos elementos que irão compor os quadros (conceito de montagem ampliado por Serguei Eisenstein ${ }^{17}$ ). Todos os elementos se relacionam, direta ou indiretamente, e só podemos compreender cada uma das partes em sua ligação com o todo.

A iluminação é um importante recurso na composição de climas e atmosferas. O teatro, por ser um campo de atuação mais livre (onde o pacto lúdico está dado primordialmente) trabalhou com este recurso de maneira mais expressiva, principalmente sob a figura de alguns encenadores, fazendo com que a luz pudesse funcionar como um cenário vivo ou até como um personagem. No cinema, o movimento que soube utilizar a iluminação com a mesma finalidade, e muito bem, foi o expressionismo alemão, que a partir de 1919 se inspirou também nas pesquisas do cineasta Cecil B. de Mille ${ }^{18}$ para expressar melhor valores psicológicos e dramáticos, tornando visíveis os estados da alma.

Muito embora a poética expressionista só tenha eclodido no início do século $X X$, essa tendência à estilização vem de muito antes. Como nos lembra Alfredo Bosi (1985), podemos percebê-la se nos voltarmos às máscaras do teatro grego ou às máscaras africanas, às figuras góticas, ao surrealismo de Bosch, ao barroco místico de El Greco, aos desenhos quase como pesadelos de Goya. Mais contemporaneamente, notamos essa estilização da forma por valores internos à obra quando observamos as pinceladas em ondas de Van Gogh, dando movimento e vibração à contemplação de seus quadros, bem como as cores "irreais" escolhidas para suas representações. Essa tendência à estilização, no entanto, só ganha consciência de si mesma com a teorização de Kandinsky, em 1954.

Voltando ao teatro, podemos citar a atuação de Gordon Craig como cenógrafo e encenador, revolucionando os recursos de iluminação, a concepção dos cenários, figurinos e proposta de encenação em favor de um espetáculo mais expressivo e limpo de detalhes supérfluos que pudessem

\footnotetext{
${ }^{17}$ MACHADO, Arlindo. Serguei M. Eisenstein. $2^{\mathrm{a}}$ ed., São Paulo: Editora Brasiliense, 1982

${ }^{18}$ O cineasta americano Cecil B. DeMille nasceu em Ashfield, Massachusetts, nos Estados Unidos, em 12 de agosto de 1881 e faleceu em 21 de janeiro de 1959, na Califórnia. Considerado um dos maiores diretores americanos, possui mais de 40 anos de carreira tendo dirigido e também produzido a maior parte de seus filmes.
} 
"turvar" o resultado final da obra. Para Craig, o espetáculo é feito do todo da encenação e nenhuma de suas partes componentes deve ser vista separadamente. Seguindo este raciocínio criativo, não era mais possível que cada profissional contribuísse para o espetáculo da maneira como julgasse apropriada. Era necessário que todos estivessem criando em cima de uma mesma e única interpretação do texto, a qual era dada pelo encenador.

O que poderia ser mais compreensível no teatro, no cinema era muito mais difícil de acontecer - essa criação pessoal, que se tornou uma marca de Fellini, é, desde o princípio, dificultada pela indústria cinematográfica. Mas ao se manter fiel a si mesmo e à sua poesia, Fellini criou uma personalização de seus filmes por meio de seu estilo e conteúdo de suas obras - um trabalho sem par.

Como Fellini, Craig também se manteve por um período da juventude por meio das artes gráficas antes de se tornar um diretor. Um interessante ponto em comum entre os dois é que Craig também fazia desenhos dos personagens durante a preparação das peças, que serviam como orientação para a confecção dos figurinos e também para a encenação dos atores. Os desenhos de Craig, intitulados cardboard figures, vinham da xilogravura, modalidade artística que colabora para a economia de traços e a precisão das formas.

Craig era um profissional extremamente exigente e normalmente não se satisfazia com os resultados obtidos em cena pelos atores. Embora suas cardboard figures (finas placas de madeira, cuidadosamente entalhadas em tamanho real) fossem feitas acompanhando o processo dos ensaios, elas tinham também a função de demonstrar visualmente aos atores como estes deveriam encenar seus personagens. É muito famosa a implicância deste encenador com o desempenho dos atores de modo geral, que gerou sua teoria sobre as Übermarionette (os atores deveriam ser super-marionetes: desta forma, os atores não alterariam nas apresentações públicas o que foi alcançado nos ensaios. Ou seja, o ator e o diretor atingiam um ponto exato que nunca mais seria repetido em função das variações de humor, saúde, problemas físicos e outros que atingiam os atores).

É curioso pensar nessa teoria tendo em vista como se dava o processo de trabalho de Fellini, que se importava mais com o aspecto visual do ator e 
escolhia a maior parte dos atores por seus "tipos" (fisionômico e/ou físico), mesmo que não fossem atores, e os fazia recitar números em frente a câmera, dublando-os mais tarde como bem o desejasse. Não seriam os atores para Fellini também uma espécie de marionetes? ${ }^{19}$

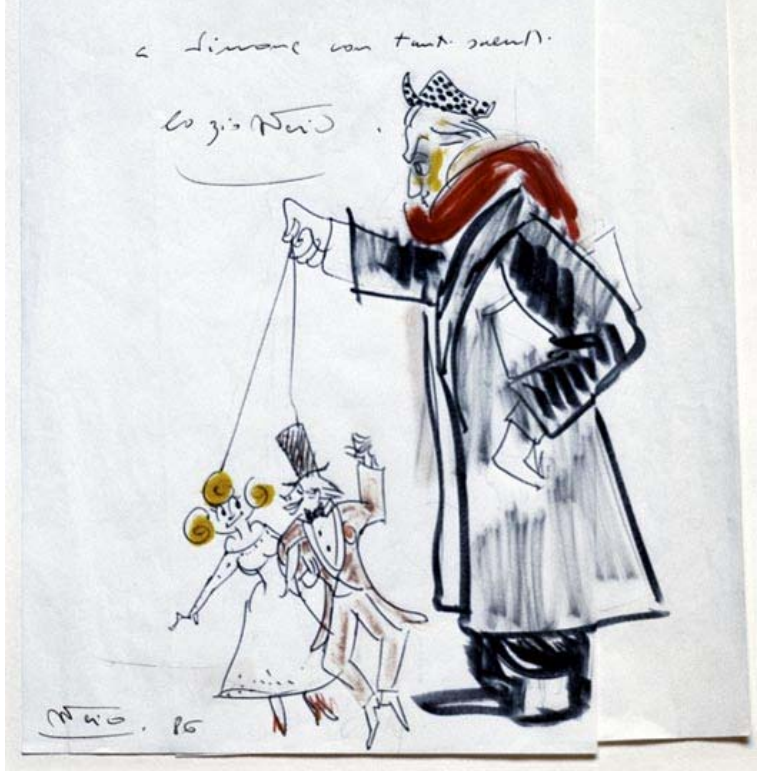

Imagem 13 - Auto-retrato de Fellini com os atores do seu filme Ginger e Fred

Craig inovou no teatro também com a iluminação elétrica e direcional, possibilitando novas maneiras de utilizar este recurso, movendo a luz de acordo com suas intenções dramáticas, muito mais livremente.

Infelizmente, com o neo-realismo italiano, por volta de 1945, as estilizações perdem força no cinema. A iluminação, por exemplo, se faz pelo uso da luz natural, resultando em imagens pouco contrastadas, registrando "a vida como ela é", como se vê nos jornais. Uma realidade que se prolonga com o movimento da nouvelle vague francesa, por volta do final dos anos 50 e década de 60, já que, assim como no neo-realismo, os seus cenários também eram reais e muitas das cenas, externas.

Como a iluminação, os outros recursos podem ser também realistas ou não. Para os figurinos, quando seguem os moldes realistas, há a preocupação de reconstituir um tempo passado, com cortes e modelos precisamente iguais aos da época, bem como devem ser rigorosos a escolha dos tecidos para a

\footnotetext{
${ }^{19}$ O termo "marionete" é usado por Donald Sutherland, Terence Stamp e pelo próprio Fellini, referindo-se ao seu trabalho com o ator em entrevistas inseridas no documentário Eu sou um grande mentiroso, de Damian Petigrew.
} 
confecção, e a pesquisa sobre os trajes usados neste tempo e neste espaço determinados.

Mas se os figurinos forem atemporais, a preocupação maior passa a ser outra: a tradução simbólica do personagem, seus estados de alma, a significação de uma determinada cena. Estes figurinos, então, podem criar mais enfaticamente efeitos psicológicos e dramáticos. Neste sentido nos importa as características plásticas dos tecidos escolhidos, seu caimento, movimento, volume e textura, além da forma intencionada para o traje, se há ou não uma estampa, e principalmente, qual a sua cor.

A escolha da cor opera no mesmo registro da escolha realista ou nãorealista dos outros recursos, e é uma das principais questões a serem resolvidas na concepção de uma obra visual.

As cores imprimem em nosso ser sentimentos e impressões, agem sobre nossa alma, sobre nosso estado de espírito; podem servir, portanto, para o desenvolvimento da ação, participando diretamente na criação da atmosfera, do clima psicológico (BETTON, 1987, p. 60).

Muitos estudos sobre a cor foram feitos. O primeiro e mais significativo é o de Leonardo Da Vinci, "Tratado da Pintura e da Paisagem - sombra e luz", lançado 132 anos após sua morte. Muito embora seus estudos se dirigissem a pintores, estavam relacionados a elementos da óptica, da física, da química e da fisiologia. Acabaram interessando a todas as artes visuais; logo, também para o cinema.

Por exemplo, a afinidade das cores com a luz e com a sombra, abordada por Leonardo, foi facilmente notada pela fotografia em preto e branco. Um estudo de cores se tornou evidentemente necessário, mesmo no caso dos filmes $P / B$, a fim de enriquecer a gama de cinzas, além de alcançar os contrastes desejados.

Dentre todas as descobertas fundamentais de Leonardo Da Vinci neste campo, a mais relevante foi a da simultaneidade dos contrastes de cor. A partir disto é que podemos constatar a ação das cores umas sobre as outras, iniciar o entendimento de como isso se dá, e constatar também a relatividade da 
aparência das cores. Outro estudo que corroborou para estas conclusões foi o de Eugène Chevreul, de onde se extrai o postulado: "as propriedades da cor só podem ser definidas em sua relação intrínseca"20. Por exemplo, uma cor nem sempre será fria ou quente, leve ou pesada, clara ou escura. Há ilusões também de espaço e volume, provocadas por essas interações entre as cores, como explica Josef Albers em seu estudo específico sobre o tema (ALBERS, 2009). Tudo depende do conjunto composto, gerando dinâmicas diferentes, que produzirão resultados diferentes.

O pintor, Wassily Kandinsky, também foi outro importante teórico sobre a cor, discorrendo sobre o assunto em sua "Gramática da Criação" (pictórica) (KANDINSKI, 2000) $^{21}$. Para ele, não interessava o efeito físico da cor, mas sim o efeito psicológico. Almejava uma teoria da criação que fosse válida para todas as culturas, buscando a composição que estabelecesse uma verdadeira ressonância com a alma humana. Essa ressonância seria alcançada por meio da harmonização entre as cores e as formas, de maneira a expressar a necessidade interior da obra. Assim, se esta meta fosse atingida, seria uma obra de arte autêntica.

Ao lembrarmos do rigor de Fellini ao colorir os seus desenhos, podemos perceber seu entendimento sobre o papel das cores na composição da imagem, sobre sua força e personalidade. Assim como Fellini, Kandinsky sempre esteve associado ao universalismo, ao misticismo, ao cósmico, em sua interpretação do mundo e em sua representação. Ele acreditava que além de técnica, era preciso intuição para enxergar o necessário a uma obra. E sua vontade era a de explorar o mundo interior das coisas, representando suas ressonâncias através de formas e cores "puras", livre da obrigação de uma representação "real".

A primeira profissão de Kandinsky também não foi a definitiva, a que seguiu na maturidade (no seu caso, a de pintor). Ele havia sido advogado até os 30 anos. Decidiu-se pela pintura após ter visto a famosa exposição dos

\footnotetext{
${ }^{20}$ Estudo de Eugène Chevreul, intitulado "Da Lei do Contraste Simultâneo das Cores e da Disposição dos Objetos Coloridos", datado de 1838. Citado pelo Prof. Dr. Donato Ferrari em disciplina "A Cor nas Manifestações Estéticas da Contemporaneidade".

${ }^{21}$ Importante ressaltar que neste trabalho utilizo de Kandinsky apenas a sua "Teoria da Criação", o modo como pensava as cores, as formas, e não suas obras pictóricas em si - não as comparo com a obra cinematográfica de Fellini nem ao menos com seus desenhos.
} 
impressionistas e após assistir a uma ópera de Wagner ${ }^{22}$. Maravilhou Kandinsky uma composição onde todos os elementos estão integrados a favor de um mesmo discurso, onde nenhum elemento foi pensado isoladamente e todos servem ao mesmo propósito, seja pela consonância ou pela dissonância entre eles. Maravilhou-o também um tipo de obra de arte que captasse e revelasse o invisível, o obscuro por trás das coisas.

Acredito que em toda obra artística, nenhum elemento deve ser "decorativo", supérfluo. Todos os elementos escolhidos devem ser absolutamente necessários, porque expressivos, e devem estar precisamente compostos. Noto que assim se dá com as melhores obras em todas as áreas, na literatura, nas artes plásticas, no teatro, no cinema e na música. Isso acontece, pois que as palavras, os sons, as imagens, não são apenas expressões do pensamento, mas têm por vezes virtudes mágicas sobre o espírito humano - logo, sua escolha deve ser muito bem feita.

Na literatura, Edgar Allan Poe, escritor americano, fundador da literatura fantástica e psicológica, estruturou seu pensamento sobre a realização de textos literários em "Filosofia da Composição". Neste texto ele fala justamente da importância da escolha perfeita dos elementos para que se alcance o efeito desejado. Numa obra há sempre os acontecimentos a serem narrados e o tom com que esses acontecimentos serão narrados - a genialidade estará na escolha de quais acontecimentos, de que tom, de qual a melhor combinação. Poe considera que o poema deve ser apreciado por todos. Seu texto deve proporcionar um prazer que seja ao mesmo tempo o mais intenso, o mais enlevante e o mais puro. Para isso, o tom usado deve ser o mais forte, mas também o mais poético e deve ter a maior carga significante possível. Para Poe, é fundamental o uso de recursos-chave. Cita como exemplo o caso de seu conhecido poema O Corvo, em que os recursos-chave usados foram: a repetição do verso "Nunca mais", o efeito de contraste e o exagero, que contamina de tristeza fatos não diretamente relacionados com o objeto da tristeza em questão, tornando tal tristeza muito mais torturante e insuportável.

Entendo que não foi à toa que pensaram assim, Fellini, Craig, Kandinky, Eisenstein e Poe. O artista não é apenas um indivíduo que intui como costuma

\footnotetext{
${ }^{22}$ Lembrar do conceito de "Obra de Arte Total" de R. Wagner, que aliava num mesmo espetáculo, música, poesia, teatro, dança e artes plásticas.
} 
apontar o lugar comum. $\mathrm{O}$ verdadeiro artista intui e conhecesse plenamente as ferramentas e técnicas de seu trabalho, utilizando-as de maneira a atingir seu objetivo com a máxima eficiência, expressar o invisível, o que se sente, o que se pensa. 


\section{Sobre a construção geral do personagem}

Voltando agora a atenção especificamente para os conhecimentos que dizem respeito à construção do personagem, sabemos que é ele o elemento que "funda" a ficção no espetáculo teatral e ainda que não seja o fundador na literatura e no cinema, é o principal elemento a constituir a ficção nesses dois meios (CANDIDO, 1972).

O conceito de personagem carrega em si o fundamental paradoxo de estar entre a ficção e a realidade, pois define um ser que é fictício, irreal, mas baseado na constituição humana, que é real. A composição do personagem está investida de um poder máximo de criação jamais podendo ser cópia fiel de um ser existente. Ainda que haja um plano passível de "cópia", o físico, por ser visível e finito, há também o plano subjetivo, que além de ser invisível, é intangível, descontínuo e infinito, inesperado (IDEM).

É nesse momento que a estética exerce seu papel primordial, permitindo-nos saber o que há por trás da realidade e nos possibilitando vislumbrar em uma obra, camadas sempre mais profundas (IDEM).

A estética confere ao personagem uma lógica própria e a ilusão do ilimitado através da combinação perfeita de um número sempre limitado de elementos de caracterização (IDEM).

Por isso, o personagem possui um número mais reduzido de aspectos do que um ser humano possui, mas ganha com isso em nitidez e um caráter definitivo que o faz tomar atitudes mais radicais, envolvendo-se muito mais vezes em situações-limite do que uma pessoa comum em seu cotidiano. $O$ personagem em relação ao ser humano, ganha em dramaticidade e expressividade (IDEM).

No processo da caracterização, o figurino é o recurso que mais comumente identifica o personagem, pois consegue definir sua classe social, idade, sexo, período do ano, às vezes nacionalidade, localização geográfica, religião, e até costumes, gostos pessoais, traços de caráter e maneiras de pensar (GUERRA e LEITE, 2001). O acessório pode sublinhar detalhes da personalidade do personagem ou servir como extensão da sua figura. 
Se esse processo contar com maior riqueza de imaginação e complexidade na composição das imagens, ao invés da preocupação com o realismo, tais construções podem proporcionar metáforas. Estas tornam visíveis aspectos invisíveis do personagem, como seus pensamentos e seu estado de espírito. Além disso, tais metáforas podem permitir a construção de outros personagens a partir do ponto de vista do protagonista, assim como a construção da própria estrutura narrativa.

Reunindo todos estes elementos estruturais, passamos agora à analise fílmica feita tendo como base as informações a respeito da vida e da obra do cineasta, bem como nos conceitos e teorias apontados neste capítulo. 
Capítulo 2

Análise da construção plástica dos personagens nos filmes

La Strada,

Julieta dos Espíritos

e Toby Dammit 
Este capítulo irá se dedicar à análise da construção plástica dos personagens principais e secundários nos três filmes do diretor Federico Fellini - La Strada (1955), Julieta dos Espíritos (1965) e Toby Dammit (1967) entendendo e demonstrando de que maneira os recursos plásticos de figurino e cenário contribuíram neste processo de composição.

\section{PARTE A - ANÁLISE DA CONSTRUÇÃO DOS PERSONAGENS NO FILME}

\section{LA STRADA}

La Strada é realmente o catálogo completo de todo o meu mundo mítico...

Federico Fellini

\section{La Strada - o filme}

Em La Strada, encontramos o espetáculo, o circo - grande influência na vida de Federico, que chegou mesmo a afirmar (ou inventar, não se sabe) que havia fugido com uma trupe em sua infância - encontramos a estrada, a eterna busca e, aqui, também o profundo desencontro entre os homens.

Um denso desencontro abordado na intenção de ajudar a resolver, ou pelo menos, chamar a atenção das pessoas para o grande problema da falta de comunicação entre os seres. Faz isso através de três personagens: Gelsomina (Giulietta Masina), Zampanò (Anthony Quinn) e "o Louco" (Richard Basehart).

O filme na época foi mal interpretado por alguns críticos que cobravam o caráter social do diretor, não vendo que a mensagem social a que ele se propunha ganhava muito mais força e abrangência justamente através da poesia que agregava à história, tão social que se punha a falar com todos os homens ao mesmo tempo. Além de propor um fim à subjugação machista sobre as mulheres, que se hoje ainda existe, na década de 50 era muito mais forte.

Assim, La Strada é um drama humano universal que se esforça por conseguir aquilo que Fellini descrevia como "a experiência conjunta do homem com o homem". Através do seu lirismo, lança-nos diante da monstruosidade da 
vida, escancara à nossa sensibilidade a angústia provocada pela solidão e pela incomunicabilidade.

O palhaço terno, ingênuo, quase assexuado que é Gelsomina, na procura do bem, reflete a alegoria simbólica de quem está à margem dessa monstruosidade. Enquanto isso, Zampanò, seu "chefe", que ganha a vida arrebentando correntes pela expansão de seus pulmões, mantém Gelsomina numa verdadeira escravidão, como que presa por correntes invisíveis, e no entanto, muito mais rígidas que o aço palpável. Zampanò é muito mais uma força bruta, que desconhece ou evita contato com os sentimentos, temendo enfraquecer-se. E, o "Louco", que é o equilibrista, o violinista e o palhaço, o grande artista com quem Gelsomina mais podia aprender, é o que mais consegue enxergar através dos problemas e sublimá-los, consegue estar acima deles (daí a imagem dele se equilibrar na corda bamba a vários metros de altura ser ainda melhor). É ele quem enxerga perfeitamente Gelsomina e fala a ela sobre a vida e o mundo com uma linguagem comum a eles dois. Uma metáfora bastante interessante e muito válida foi adotada pela crítica americana, que considerou esses três personagens como representantes da alma (Gelsomina), do corpo (Zampanò) e da mente (o Louco).

Por fim, Fellini recebeu por este filme o seu primeiro Oscar (Melhor Filme Estrangeiro, 1955) e mais de 50 prêmios internacionais. Foi um marco não só na carreira de Fellini, como também na cinematografia européia da segunda metade de século $X X$.

\section{Análise Geral do Filme e dos Personagens}

O personagem Gelsomina vem de uma família pobre da Itália, é filha de mãe viúva e tem muitos irmãos menores. A irmã mais velha, cujo nome era Rosa, não chegamos a ver no filme, temos apenas a sua referência e sabemos que ela morreu durante o período de tempo que esteve com Zampanò, sendo sua ajudante.

A palavra, Gelsomina, significa jasmim, uma flor que por si só já expressa em comparação à rosa, mais simplicidade, por ser uma pequena flor do campo, maior fragilidade e delicadeza tanto no tamanho, como na coloração e no perfume. A comparação é feita entre as duas personagens logo no início 
do filme, quando a mãe diz que não é culpa de Gelsomina não ser como as outras. Ela é tida como uma moça diferente das demais, e tão logo pensamos que deve haver algo esquisito nela, já começamos a procurar o "defeito". Talvez seja por não ter grandes atributos físicos, já que não é alta, não tem seios fartos, nem belas curvas; talvez seja por não saber cozinhar, nem cantar, ou dançar... Qual será a "utilidade" de Gelsomina? O filme trará mais tarde, na figura do Louco, um discurso sobre a "utilidade" das coisas, mesmo as mais inimagináveis.

Pois com este mesmo caráter utilitário, ela é praticamente vendida a Zampanò quando o vemos dando dinheiro a seus irmãos para comprar comida. Ao fim da negociação com a mãe, as crianças são obrigadas a agradecer, enquanto Gelsomina volta-se para o mar e ajoelha-se, despedindo-se com um olhar demorado e sereno, quase como se pedisse sua bênção.
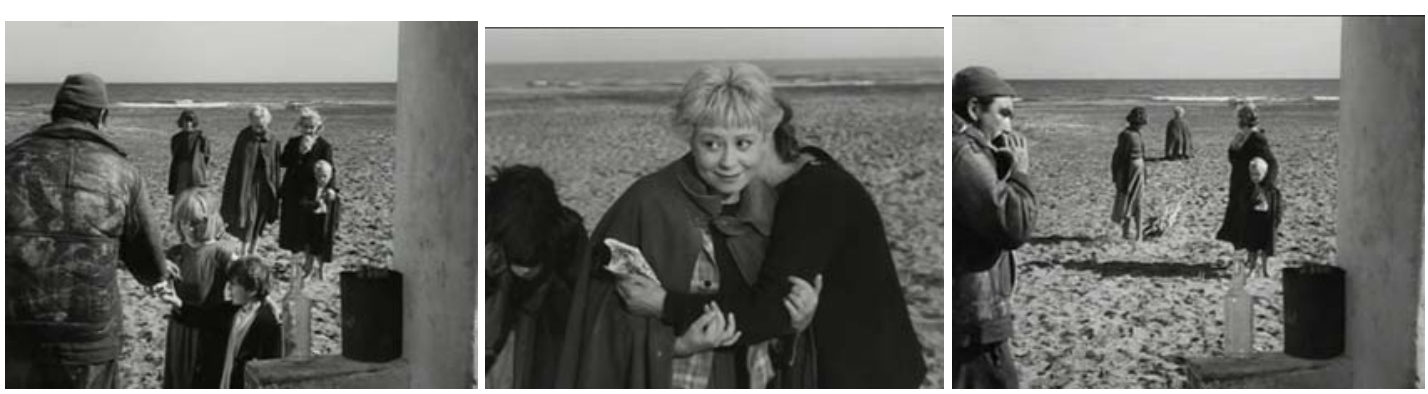

Imagens 3, 2 e 3 Gelsomina é praticamente vendida a Zampanò e vai se despedir do mar²3

Este personagem é plenamente integrado à natureza, o que esta cena evidencia muito bem - ainda mais do que aquela anterior, a primeira imagem do filme, quando a vemos recolhendo gravetos na praia. Outra cena que apresenta esta evidência é a que Gelsomina planta tomates pela estrada apenas pelo prazer de haver semeado algo, de imaginar que um dia irá brotar e dar bons frutos. Mas há inúmeras outras nos demonstrando esta integração, principalmente as que revelam as estações do ano e as paisagens, ao longo do filme, evocam com clareza seu estado de espírito.

\footnotetext{
${ }^{23}$ Todas as imagens do filme La Strada nesta análise são fotogramas extraídos diretamente do filme em questão, salvo as que têm outra fonte apontada.
} 

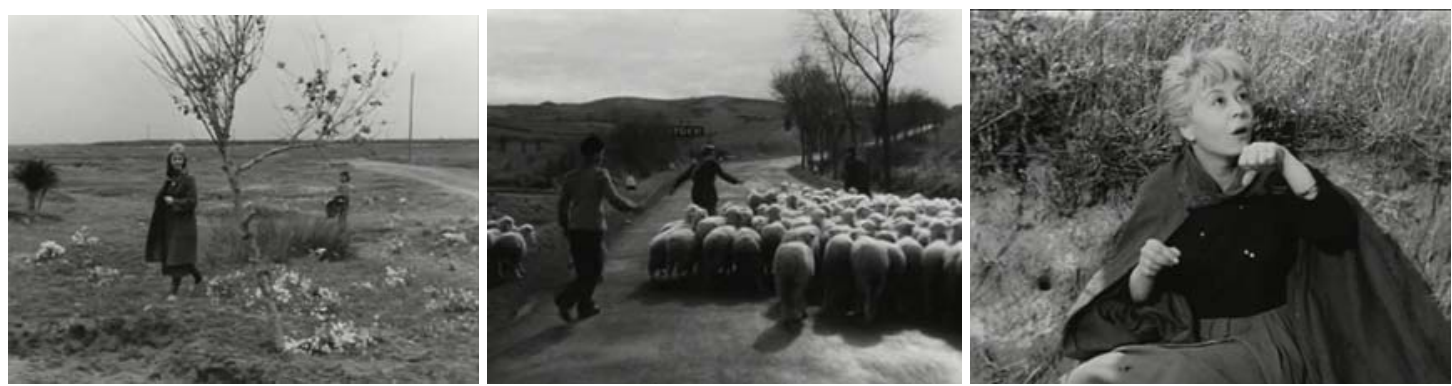

Imagens 4, 5 e 6 Gelsomina encontra flores pela estrada, sementes, animais

Dessa maneira, a estrada, em toda a primeira parte do caminho, está repleta de pequenas flores do campo, as quais ela observa, colhe, ao mesmo tempo em que vamos sendo apresentados ao seu personagem. É primavera, o cenário é bonito, parece fértil. Inspira em nós a mesma esperança que sente Gelsomina. Isto acontece porque a estrada é um cenário escolhido não por acaso e trabalhado como uma extensão do personagem por toda a sua trajetória como abordaremos ao longo desta análise. Este cenário é um espaço prolongado, não é um espaço fixo e limitado, demonstrando inclusive o não pertencimento do personagem a nenhum lugar, o seu caráter nômade.

Amável, ingênua, alegre, otimista, sempre disposta a crescer e a aprender, seu personagem identifica-se em muitos momentos com as crianças. São exemplos dessa identificação, a primeira cena em que ela está na praia e as crianças a chamam; a cena em que Gelsomina amanhece ao relento numa sarjeta, ressentida por ter sido abandonada por Zampanó e trocada por uma prostituta, apenas crianças vêm em seu consolo; e depois, durante a festa de casamento, quando crianças também a chamam para alegrar o menino adoentado e que é mantido na cama, distante da luz e das alegrias do mundo, sob a tutela de freiras esbravejantes.
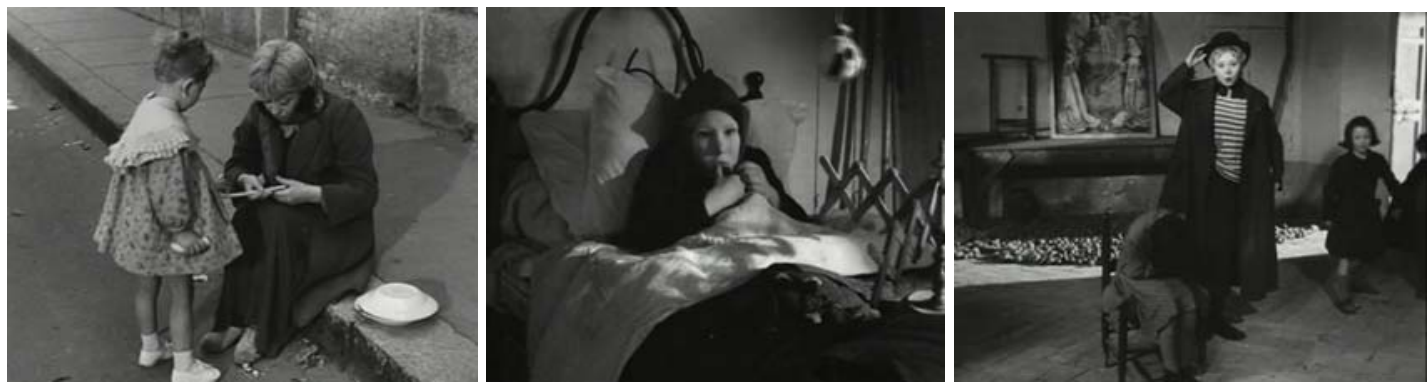

Imagens 7, 8 e 9 Na ausência de Zampanò, as crianças rodeiam Gelsomina - elas a consolam e ela as alegra

Além do aspecto da identificação existe também a questão de que nos momentos em que as crianças aparecem, é sinal de que ainda há alguma esperança em Gelsomina e no olhar dela sobre o mundo. 
Mas ainda dentro da relação de identificação, pode-se dizer também que a disposição que ela possui como as crianças, para crescer e aprender, é que Zampanò poda, limita, castra. Ela não tem liberdade para tocar o tambor e anunciar o show como bem entender, tem de fazê- lo como ele manda, pois caso contrário, receberá castigos físicos.

Imagem 10 Gelsomina apanha se não tocar o tambor como Zampanò quer

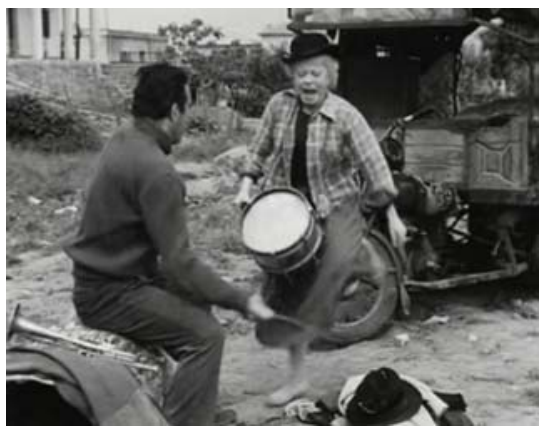

A identidade artística de Gelsomina, assim, vai crescendo aos moldes de Zampanò, bastante deficiente e entristecida de nunca poder desenvolver seus próprios talentos e lançar-se aos desafios e encantos do mundo do espetáculo, seguindo suas próprias intuições e vontades, como ela havia imaginado um dia.

Por isso tudo é que, certa vez, Gelsomina toma coragem e foge, preferindo desbravar o mundo sozinha. Quando ameaça perder a coragem, senta-se na beira da estrada um pouco desiludida e é surpreendida por um trio de músicos passam tocando três instrumentos de sopro e ela decide seguir.

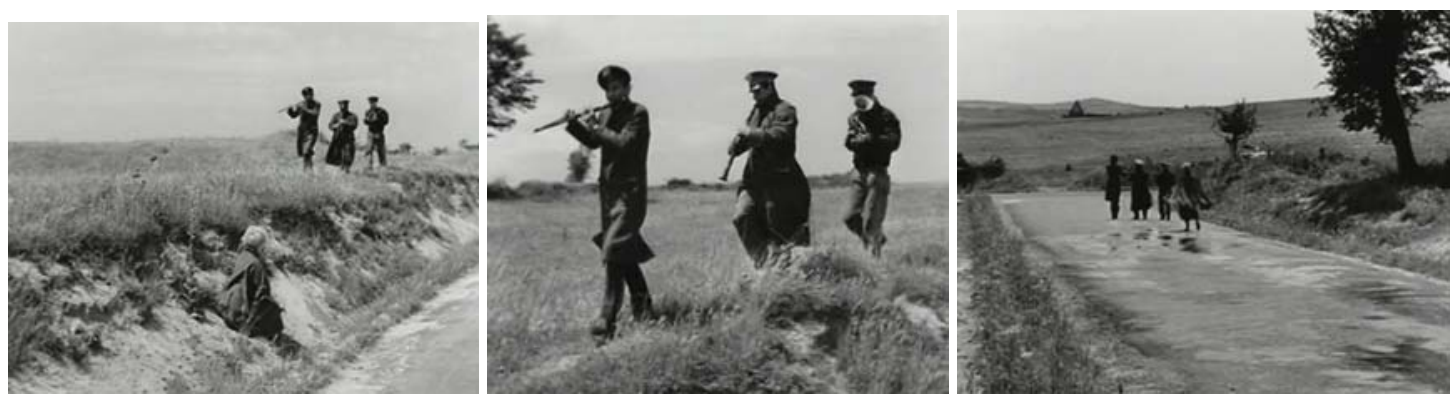

Imagens 11, 12 e 13 Gelsomina vê passar os três músicos e decide segui-los

Esta cena não apenas antecipa a próxima, a da procissão, mas também o personagem leve de II Matto e aponta para o fato de Gelsomina se sentir sempre impelida a seguir o espetáculo, a música, a alegria. Como uma metáfora para a vida do personagem de Giulietta, ela se mete no meio da multidão, cheia de curiosidade e, num instante, vai sendo arrastada pelas pessoas que caminham com imagens de santos, numa gritaria que fora de contexto pareceria insana - é uma procissão. Gelsomina é a única que pára para olhar ao seu redor, querendo ver a beleza das coisas, reparar nos 
detalhes e, por isso mesmo, é atingida com mais força por essa multidão, com certa violência até. Mesmo quando entra em outra rua, tentando escolher outro caminho, novamente surgem mais e mais pessoas, vindo na direção contrária à sua, e ela é obrigada a seguir o fluxo.
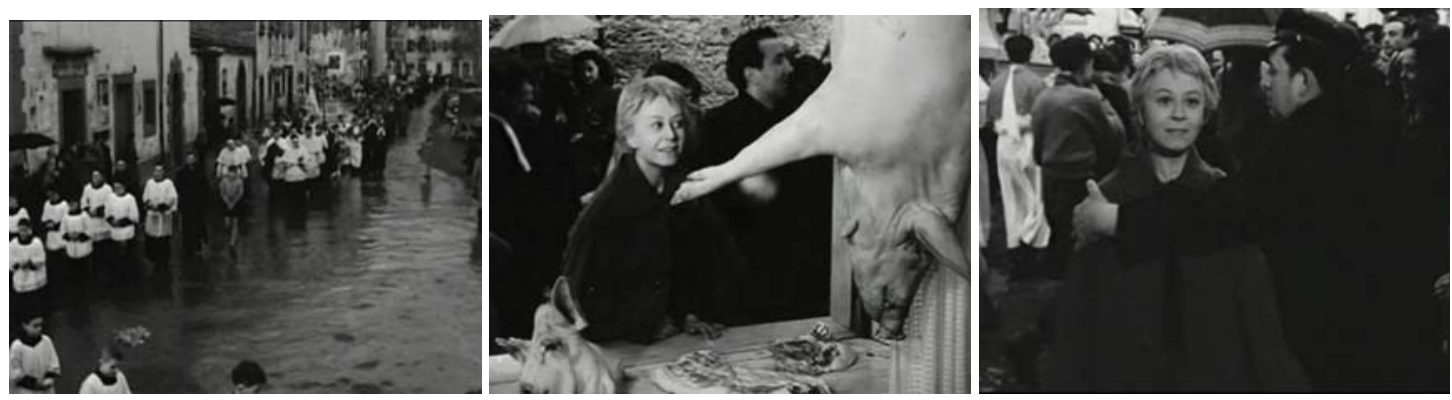

Imagens 14, 15 e 16 Cenas da procissão na qual Gelsomina entra

Durante esta mesma procissão, Gelsomina se assombra com o sacrifício de alguns animais em oferenda num altar, o que, seguindo a intenção da metáfora, antecipa-nos o fato de que ela também acaba se oferecendo em sacrifício de Zampanò, pois é preciso que ela sucumba de tristeza e solidão para que o personagem de A. Quinn perceba a real dimensão do amor que sentia por ela e da importância desta mulher em sua vida.

A procissão, como manifestação popular genuína, também poderia ser vista como um riquíssimo espetáculo, que ao mesmo tempo assombra e deslumbra. Enxergando por este prisma, talvez o fluxo da procissão a arraste como seu próprio impulso vital, que a leva em direção às artes, à música, ao espetáculo teatral, também sem que consiga evitar.

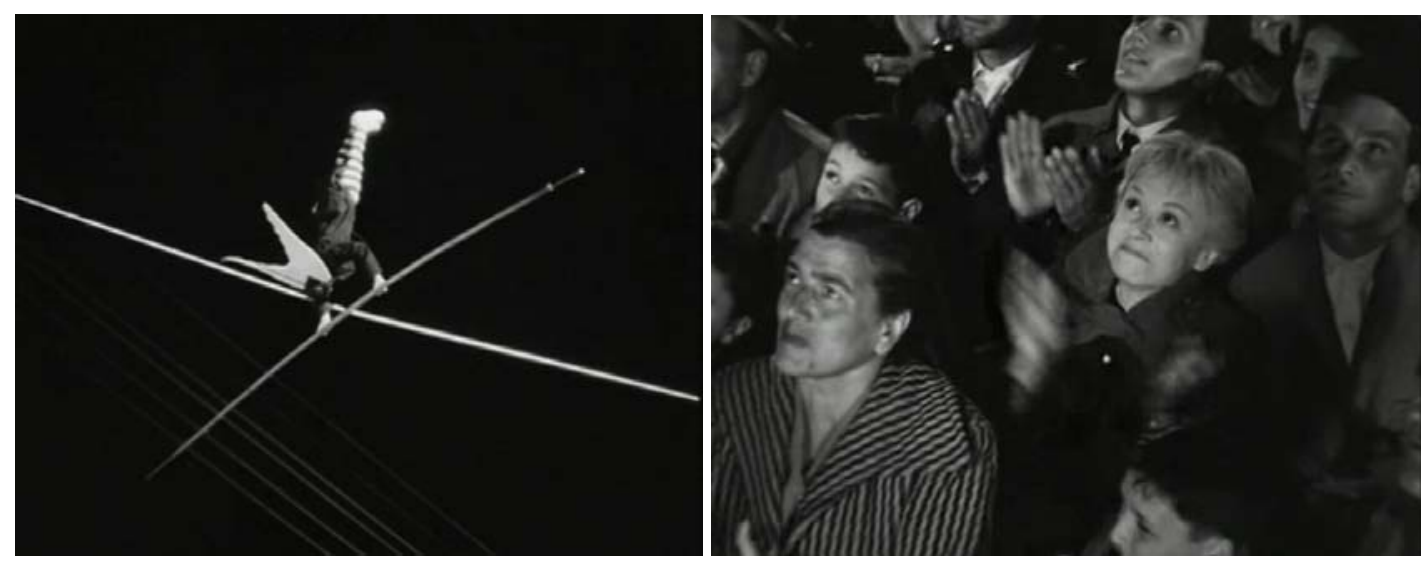

Imagem 17 e 18 Louco faz seus números de equilíbrio e Gelsomina o aplaude admirada

Passada a procissão, a próxima cena é noturna e ela está sozinha na cidade. Vê-se acima de outra grande multidão, um equilibrista vestido de 
palhaço - o Louco - o qual, desde então Gelsomina passa a admirar por seu humor, coragem e ousadia.

Porém, sua peregrinação solitária não vai muito além disso. Finalizada a apresentação do equilibrista, depois que todos se vão para suas casas e ela fica ali na praça, ao relento, Zampanò reaparece e a resgata aos bofetes e sopapos. Vemos medo no rosto de Gelsomina e a praça está deserta, coberta de folhas secas que rodopiam com um vento frio.
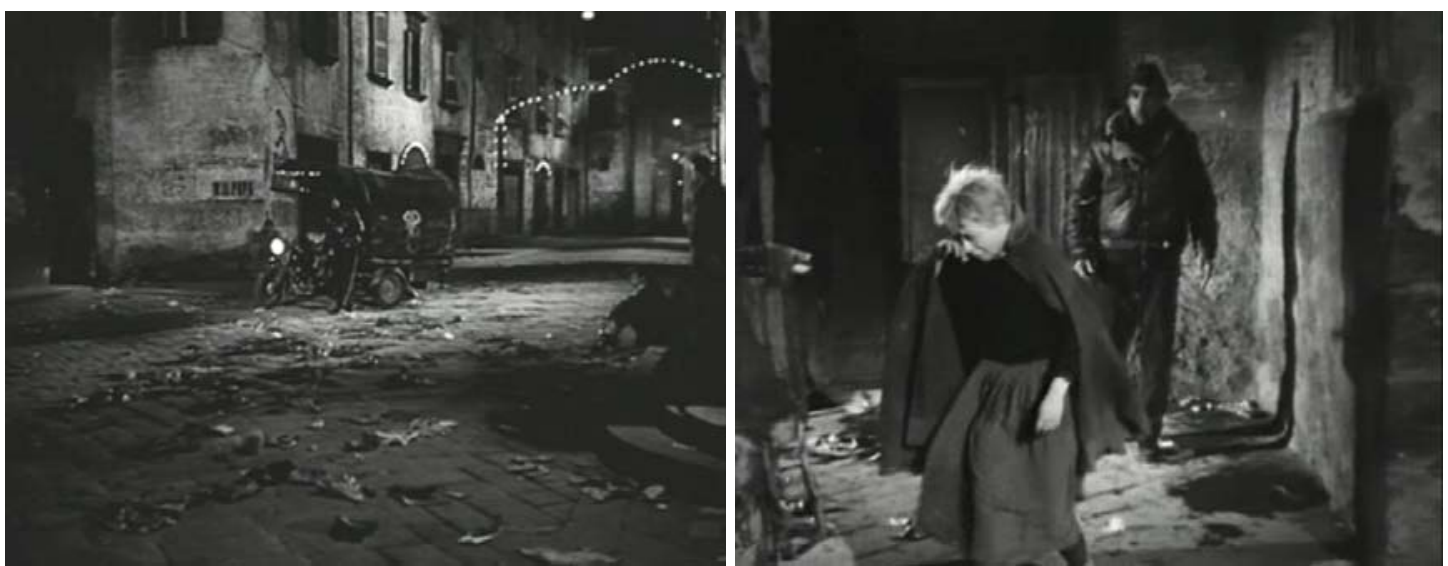

Imagens 19 e 20 Praça onde Zampanò reencontra Gelsomina e a obriga a voltar a trabalhar com ele

Esta cena nos dá outro tipo de sensação em relação aos dois e em relação a Gelsomina, principalmente se a compararmos às primeiras, em que a paisagem era amena, a estrada cheia de flores e ela tinha ânimo até para plantar sementes. A estação agora é de outono e as árvores já não tem mais quase folhas, numa evolução integrada ao personagem de Gelsomina cuja vitalidade também está se ressecando com as agressões ao redor, torna evidente o declínio de suas esperanças.

Estas agressões que não cessam e partem sempre de Zampanò, atingindo o ponto máximo com a morte por espancamento sofrida pelo Louco na última briga que têm os dois.

A morte do Louco deixa Gelsomina tão abatida justamente por morrer a pessoa mais admirável do mundo a seus olhos, e pelas mãos daquele que ela ama, Zampanò. O Louco representava para ela uma espécie de mestre, abrindo seus olhos. Ao matar o Louco, é como se houvesse extinguido esta sabedoria do mundo, provando que não é ela que prevalece, tornando frágil também a possibilidade de crescimento e mudança para ela. É como se houvesse matado toda a alegria e a coragem representadas pelo Louco, por ter sido ele o único a compreendê-la de verdade, a abrir sua visão, mostrando que 
haviam outros caminhos e que ela não precisava ficar sob o domínio daquele tirano.

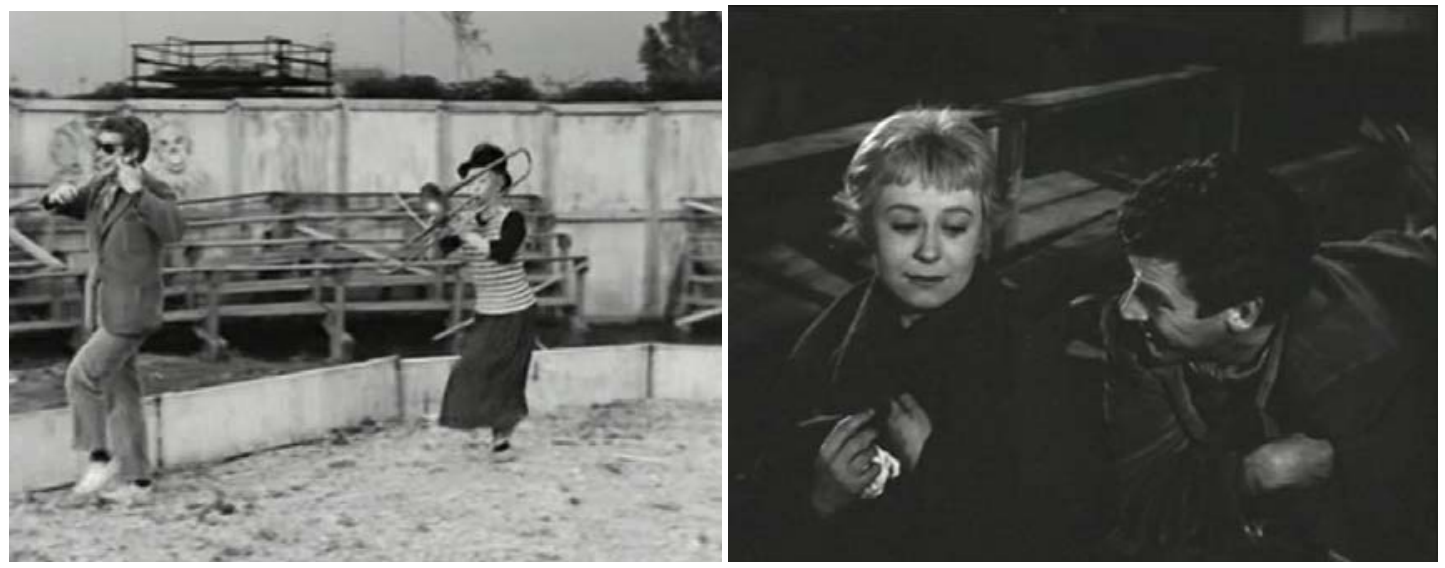

Imagem 21 Louco ensina novo número a Gelsomina quando estão no circo o que provoca briga entre ele e Zampanò.

Imagem 22 Cena da conversa sobre a utilidade das coisas: "Até essa pedra é útil"

Pela conversa que os dois haviam tido na noite em que Zampanò foi preso, fica claro que Gelsomina poderia ter seguido viagem com o Louco se quisesse, enquanto aprenderia mais coisas até poder cuidar sozinha de sua vida. Percebemos inclusive que ela parece pender para o lado do Louco - é com ele que ela gostaria e deveria ficar. Ambos possuem a mesma sensibilidade e vitalidade, entendem-se bem e divertiriam-se muito juntos. Esta seria sua oportunidade de crescer em todos os sentidos. No entanto, Gelsomina em toda a sua bondade, sente pena de Zampanò quando pensa que se ela não cuidar dele, ninguém mais o fará, e esta seria sua maior utilidade na vida.

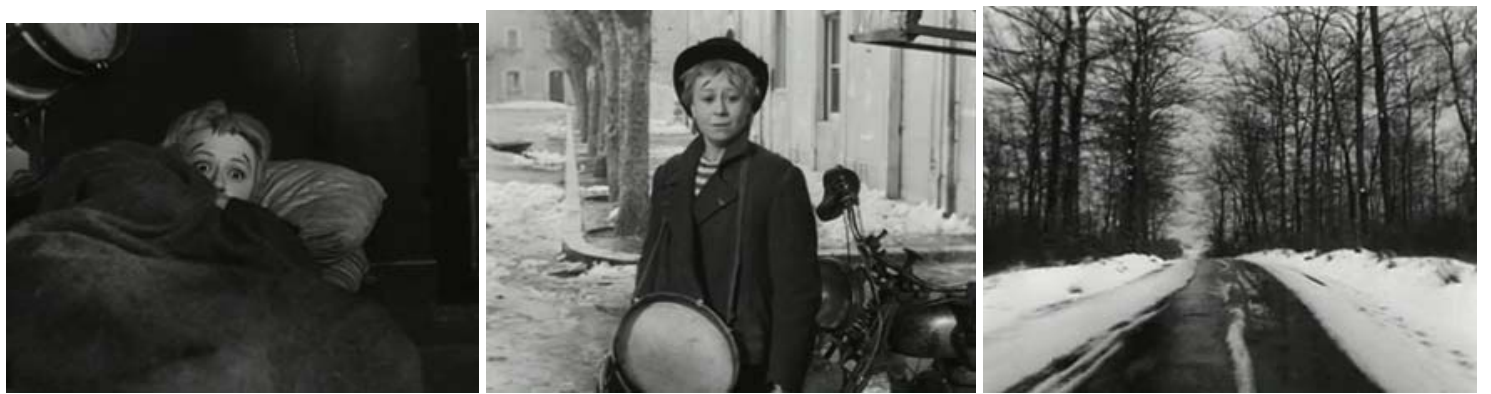

Imagens 23, 24 e 25 Gelsomina adoece, não consegue comer, falar ou trabalhar, sente pavor de Zampanò. Cenário acompanha evolução do personagem

Com tamanho abatimento, Gelsomina já não fala e nem come. A tristeza tomou conta - seu corpo e raciocínio estão debilitados - e ela precisa de muitos cuidados e atenção, mas talvez nem isso fosse suficiente, talvez já fosse tarde e nada mais pudesse reparar estrago tão desmesurado. Quem 
sabe uma mudança radical no comportamento de Zampanò pudesse salvá-la, mas ao invés disso, ele a abandona adormecida à beira da estrada.

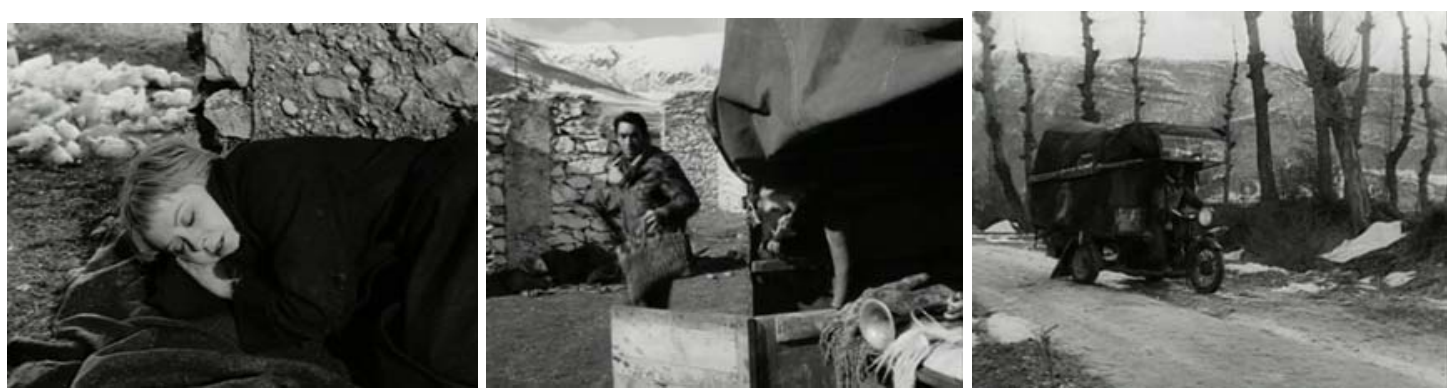

Imagens 26, 27 e 28 Gelsomina permanece adormecida e Zampanò a abandona à beira da estrada

Faz mais frio ainda, há neve, é inverno. Mais uma vez, como já foi apontado nas sequências anteriores, podemos acompanhar visualmente a evolução do personagem na narrativa, murchando, se esvaindo de tristeza. 0 estado de espírito de Gelsomina e a paisagem que observamos estão em absoluta sintonia.

Conforme Zampanò vai se distanciando, vemos que para o sentido em que ele vai, a paisagem é inóspita, de relevo acidentado, repleto de montanhas e gelo, exatamente como é cruel e rude a sua atitude de partir neste contexto. Onde Gelsomina permanece deitada dormindo, há uma pequena fogueira, paredes inacabadas e destruídas. Mais uma vez, as imagens traduzem com perfeição os dois personagens: Gelsomina, a quem não foi dada a chance, como pessoa, de se desenvolver e de encontrar seu espaço no mundo, restam apenas as ruínas das paredes que nem chegaram a ser terminadas, comparando a construção de sua estrutura psíquica, emocional e profissional com as estruturas de uma casa. Zampanò, de natureza sempre bruta e hostil, é como a paisagem congelante e agressiva a que ele se dirige.
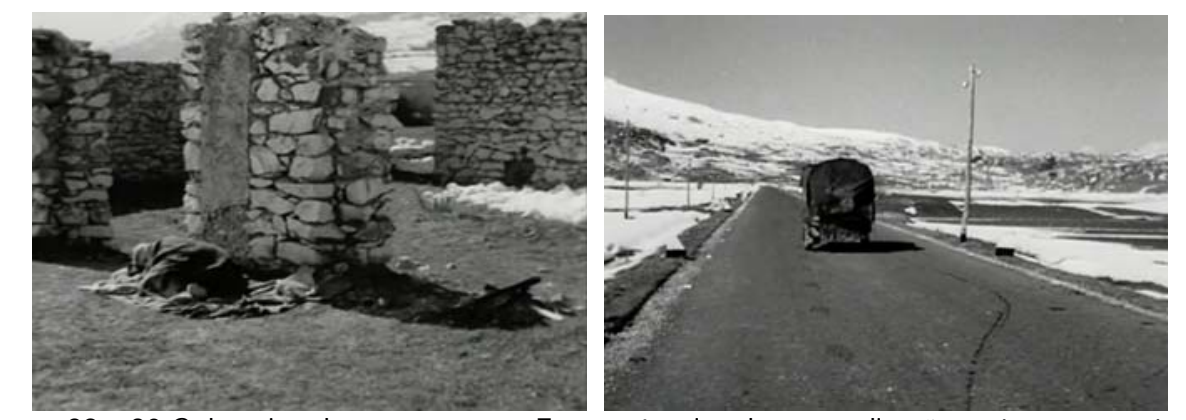

Imagens 29 e 30 Gelsomina dorme na neve e Zampanò vai embora em direção ao terreno montanhoso

Outro meio que ajuda a construir o personagem de Gelsomina é a música, e ela aparece diversas vezes sendo tocada por Gelsomina e seu trompete. O Louco também a toca no violino em uma cena, mas isto acontece 
muito mais para reforçar a ligação existente entre os dois, tendo como enfoque principal Gelsomina, demonstrando como o Louco a compreende e é capaz de enxergar o que há em sua alma, ao passo que também chama nossa atenção para os pensamentos dela. Assim, mesmo depois de sua morte, ao ouvirmos a música que ela tocava no trompete, é como se ela voltasse à cena, sentimos fortemente a sua presença através do tema criado por Nino Rota. Também podemos pensar que a música, enquanto arte, permanece. Mesmo que o artista se vá, é maior do que ele, permanece como sua contribuição para o mundo.

Tal sensação é reforçada por outro aspecto, os figurinos usados por duas passantes em segundo plano, atrás de Zampanò exatamente neste momento: uma mulher de saia listrada em preto e branco e uma menina saltitante com um vestido também listrado nessas cores - em ambos os casos, as listras possuem o mesmo padrão usado por Gelsomina.
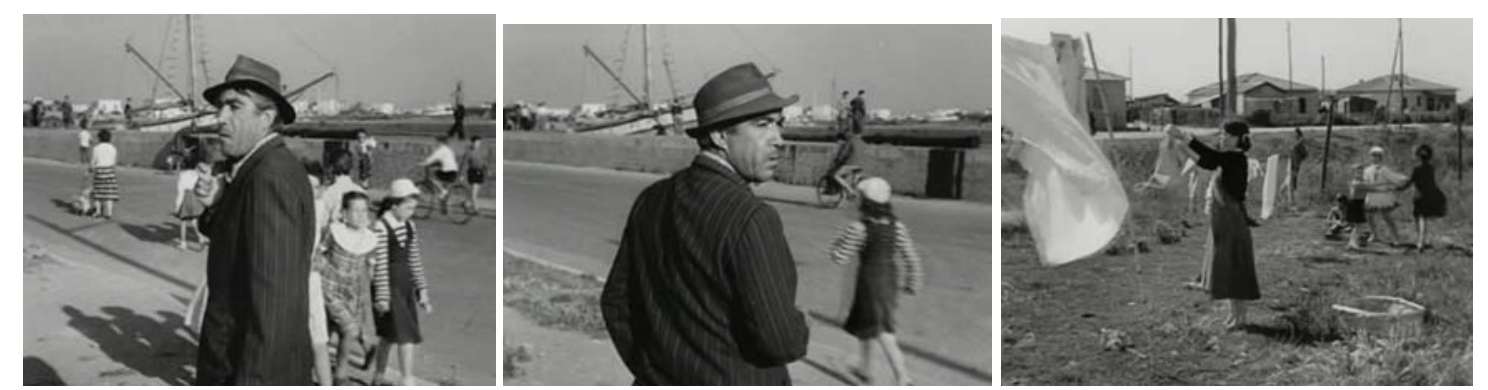

Imagens 31, 32 e 33 Zampanò ouve música de Gelsomina duas vezes, procura de onde vem e vê a mulher cantarolando rodeada de crianças. Figurinos listrados no mesmo padrão de Gelsomina aparecem junto com a música

E como se não fosse suficiente, a atuação de Anthony Quinn vem e nos dá a certeza: Zampanò ao ouvir a melodia, imediatamente vai perguntar à mulher que a cantarola - como ela teria conhecido aquela canção? A mulher responde, e sem saber de seu envolvimento com a "moça do trompete", conta que ela morreu já há cinco anos, de tristeza provavelmente.

A partir da notícia, Zampanò não dá imediatamente indícios de que mudará, de que se tornará uma pessoa diferente. Mas desmorona por dentro e é (possivelmente) na mesma noite que o vemos caído na areia à beira-mar (elemento inicialmente ligado à figura de Gelsomina), entregue à solidão, ao remorso, ao infortúnio de só agora ter enxergado Gelsomina como ela merecia em vida e, então, chora copiosamente entregue ao seu amor pela pequena que se foi. 

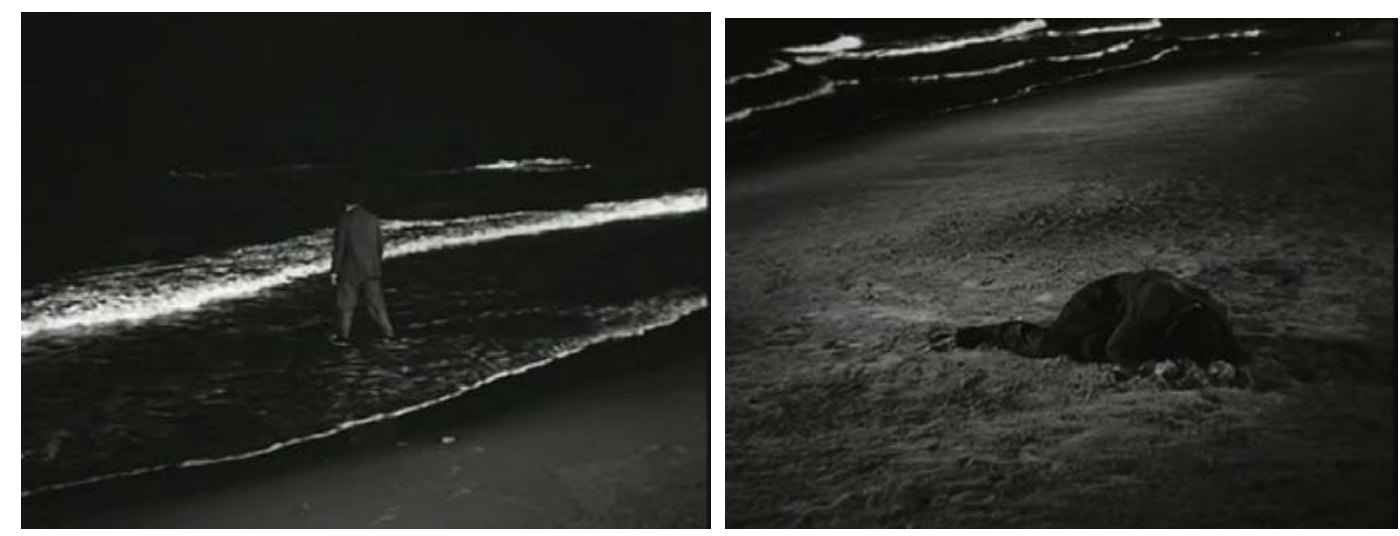

Imagens 34 e 35 Zampanò, junto ao mar, sofre de tristeza e solidão

\section{Gelsomina}

Os figurinos usados por Gelsomina são basicamente dois: o primeiro, que é o que ela usa durante todo o filme, quando não está se apresentando com Zampanò, e o outro é o que é usado nas apresentações. Em ambos os casos, os figurinos revelam o baixo poder aquisitivo do personagem. Ela usa sempre a mesma roupa, de forma que as peças parecem bastante puídas e algumas já nem possuem arremates.

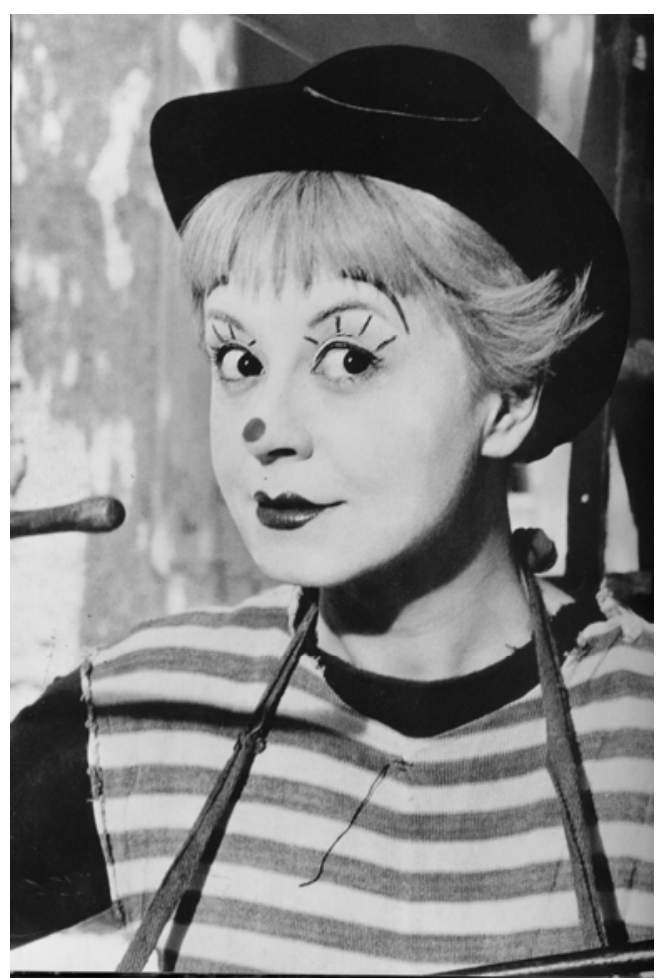

Imagem 36 Giulietta Masina interpretando Gelsomina (WIEGAND, 2003, p.46)

O primeiro figurino é composto por uma saia de comprimento um pouco abaixo do joelho, de cor cinza, em lã, lisa, sem pregas; uma capa muito simples 
e popular, com abas que se abrem lateralmente conforme ela caminha, fazendo lembrar asas e antecipando seu caráter sonhador, leve, voltado para as coisas de igual natureza; nos pés, calça velhos sapatos brancos que se parecem com tênis do tipo "keds".

Já o figurino das apresentações é composto por uma blusa preta de malha com mangas compridas, sem acabamento de costura nem na gola e nem nas mangas. Sobre esta blusa preta, há outra blusa de malha, só que sem mangas e com listras largas em preto e branco, sem acabamento de costura nem na gola nem nas mangas também. A saia continua sendo a mesma saia cinza, lisa, de lã; chapéu coco preto - lembrando mais uma vez a influência de Charles Chaplin na composição deste personagem, assim como na estrutura deste e de outros filmes da primeira fase de Fellini, além de lembrar também o vestuário de um clown.

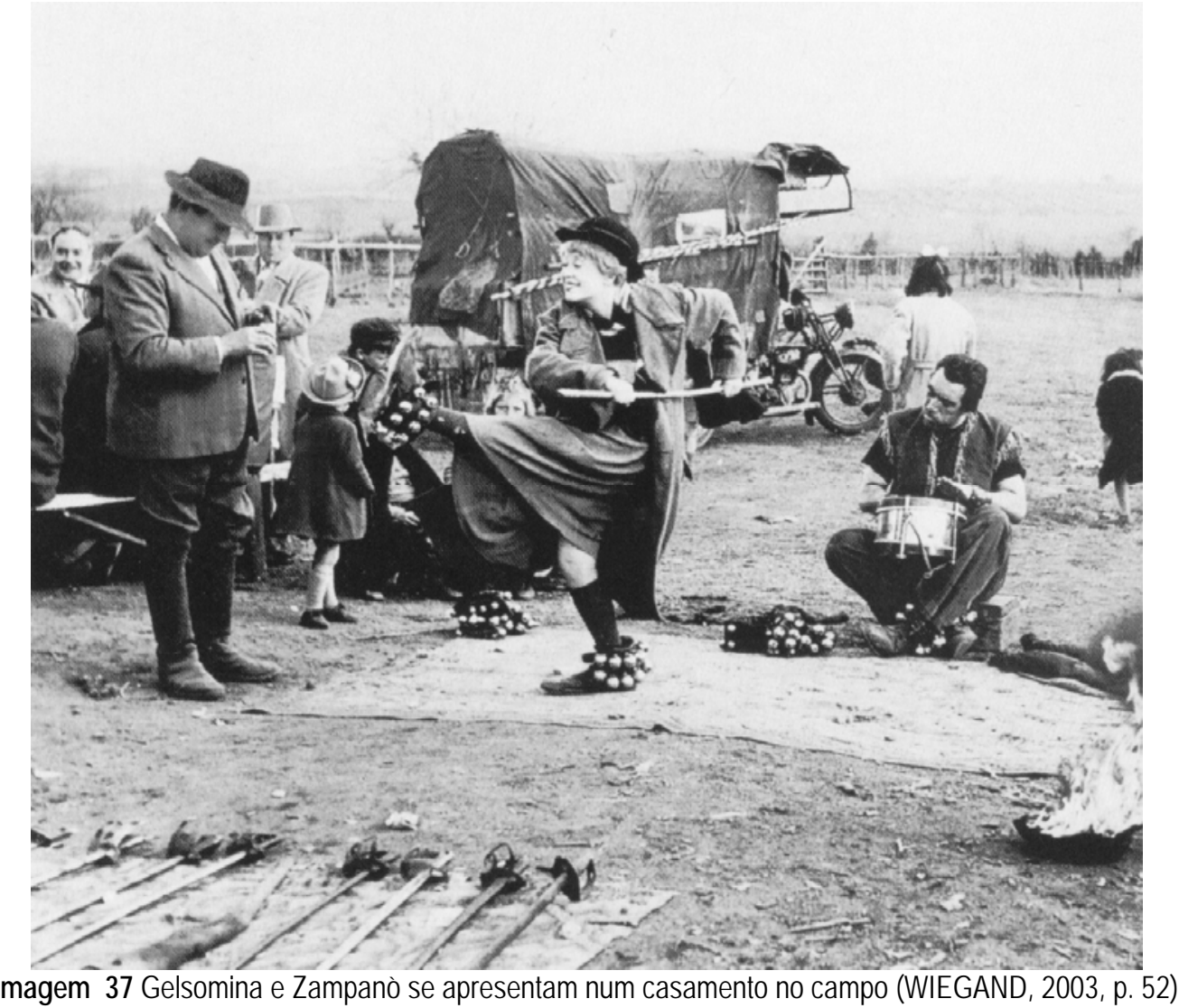

$\mathrm{Na}$ apresentação que fazem no casamento no campo, Gelsomina usa um casaco um pouco militar, de linhas mais masculinas que as de sua capa, denunciando a influência de Zampanó na composição de sua identidade artística. Outros elementos de seu visual acompanham esta tendência: meias três quartos pretas de lã; tornozeleiras pretas, largas, com muitos guizos 
prateados; sapatos de palhaço (do tipo comprido e de bico arredondado) na cor preta; e o mesmo chapéu coco preto.
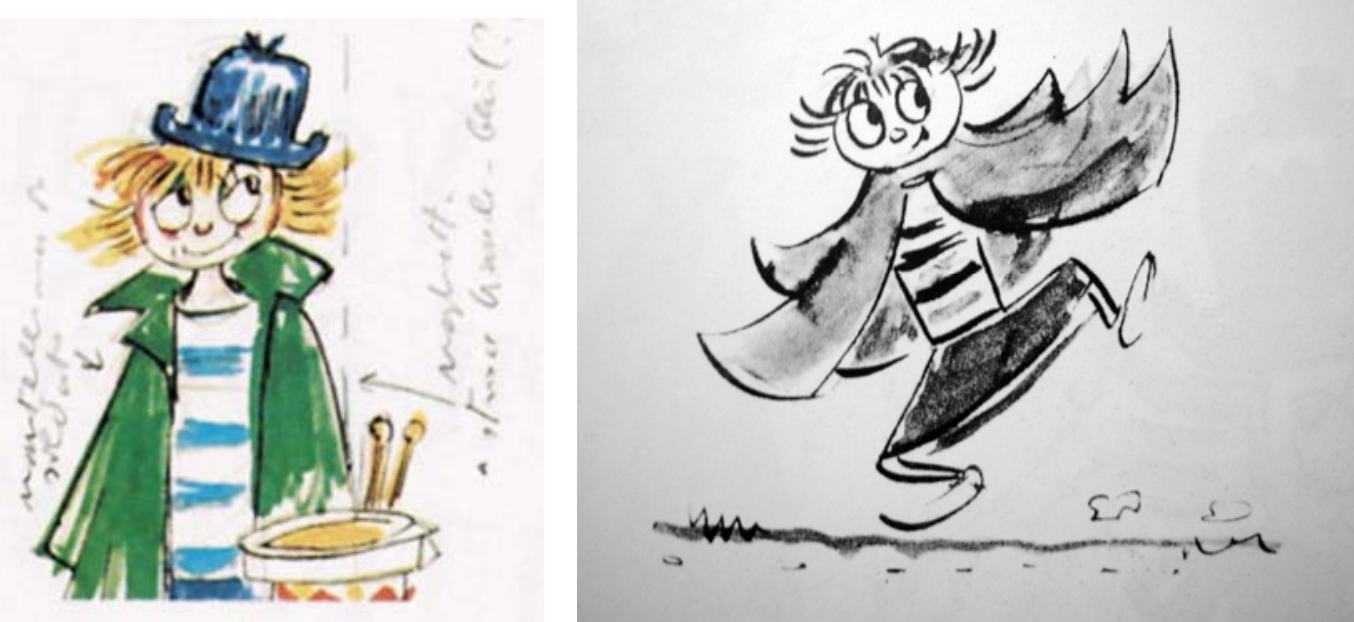

Imagem 38 Um dos desenhos de Fellini para este personagem (SANTI, 2004, fig. 24)

Imagem 39 Desenho de Fellini que realça efeito da capa e do corte de cabelo de Gelsomina (IDEM, fig. 25)

Os desenhos de Fellini evidenciam uma associação de Gelsomina a um universo clownesco, mas talvez também possamos associá-la imageticamente a uma boneca de pano, objeto bastante popular e pertencente à memória de todo espectador. O cabelo criado para Gelsomina, desde o princípio imaginado por Fellini em seus desenhos, era um cabelo curto, repicado a partir da franja até a nuca, com aparência espevitada. Com exceção da franja, as pontas fazem uma curva de modo que estão sempre apontando para cima, como a lembrar que ela está sempre na contramão da normalidade, sempre a desafiar o modo de ser, comum, das pessoas em geral. Este penteado reforça seu caráter assexuado, sua natureza livre e distraída de vaidades, avoada, infantil.

A maquiagem criada para ela tem fundo branco, duas sobrancelhas altas e bem marcadas, revelando uma expressão sempre exclamativa e entusiasmada (que combina com a natureza do personagem). Os lábios são femininos, delicados e pequenos; na ponta de seu nariz, uma bolinha pequena foi desenhada, dando o ar engraçado de "clown augusto" em que ela também foi inspirada (KEEL; STRICH, 1983, p. 105-108). O "Clown augusto" vem do palhaço Auguste, irmão pobre do palhaço rico do tradicional circo europeu. É um palhaço que existe no contraponto com o "clown branco". O augusto é maltrapilho, quase sempre infantil, atrapalha-se, sem nunca conseguir fazer o 
que o clown branco faz. Esperneia como uma criança, está sempre tendo que se submeter às ordens do branco que, bem vestido e arrogante, o humilha.

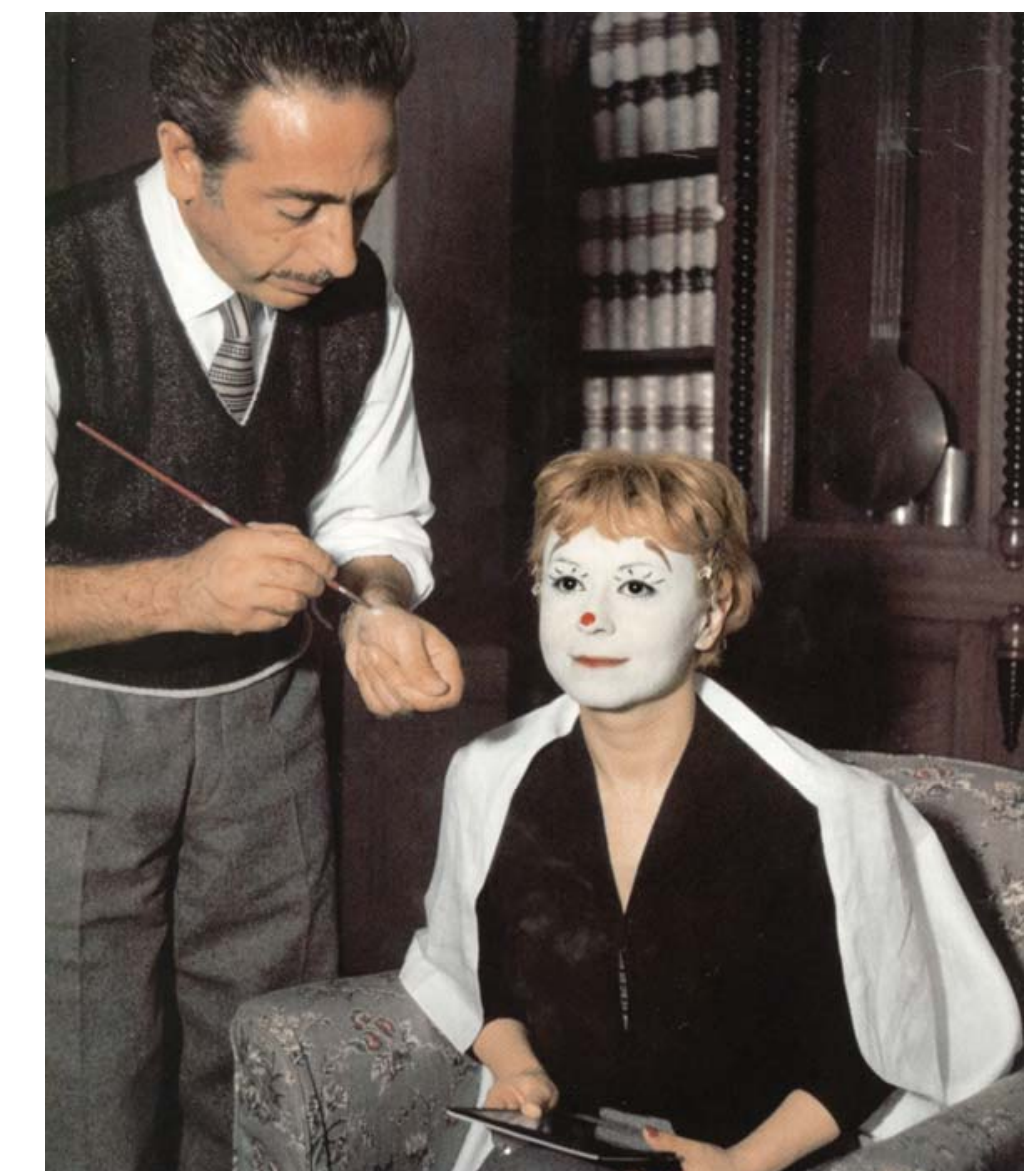

Imagem 40 Giulietta sendo preparada pelo maquiador nos bastidores de La Strada (WIEGAND, 2003, p.51)

Voltando à maquiagem, os olhos de Gelsomina foram delineados, para ficarem mais expressivos, e delineados apenas na parte superior para garantir, apesar da expressividade, leveza ao olhar; nas pálpebras. Como as de uma boneca, quatro traços retos saem convergindo do centro de seus olhos, como se alongassem os cílios. Ao mesmo tempo, parecem imitar pequenos raios, fazendo os olhos de Giulietta como dois pequenos "sóis" em expansão, numa associação do brilho e da sensibilidade de Gelsomina com a vida de um verdadeiro artista. 

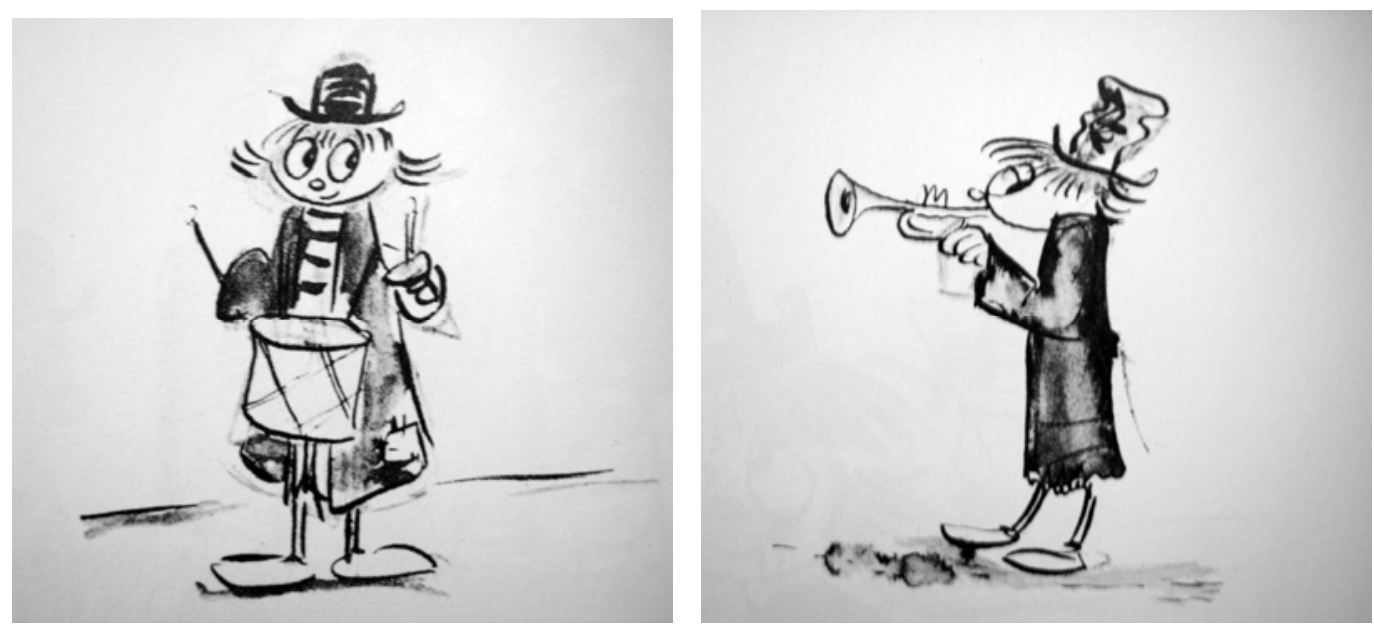

Imagens 41 e 42 Desenhos de Fellini para Gelsomina tocando tambor e trompete (SANTI, 2004, p. 60)

Cada um dos três personagens principais do filme parece estar mais ligada a um ou dois objetos mais importantes e sintetizadores de algum significado. Gelsomina está ligada aos dois instrumentos musicais: o tambor (que é o primeiro com que se relaciona) e o trompete (que é o segundo, mas parece ser mais definitivo, e demonstra uma certa evolução pelo maior grau de dificuldade). O fato de ligar-se aos instrumentos musicais nos lembra da música com a qual ela se identifica em vida, que a personifica após sua morte e a imortaliza, diante dos que a conheceram. Esta ligação com a música também explicita a identificação com o mundo das artes, com todos os elementos leves, agradáveis, alegres e que se sustentam no ar como o som de seu tema. Além disso, podemos pensar no trompete como um instrumento de sopro associando-o ao sopro da vida. Se lembrarmos que o trompete entra na vida de Gelsomina só depois que ela conhece o Louco, aquele que revigora seus ânimos e os significados de sua existência, podemos entender esta associação.

\section{Zampanò}

O personagem de Anthony Quinn, Zampanò, foi construído inspirado nas memórias assustadoras que Fellini tinha de um castrador de porcos da Gambettola, uma das cidades de sua infância.

Este personagem mantém o caráter bruto, de aparência insensível e castradora. É ele quem manda, quem dita as regras o tempo todo, um 
verdadeiro tirano. Não parece usar seus sentimentos nem seu raciocínio, usa apenas a força bruta.

Assim, se ligarmos sua figura à de algum objeto com que se relaciona durante o filme, este objeto será as correntes. E podemos enxergá-las em dois sentidos: as correntes de aço que ele arrebenta com a simples expansão de seus pulmões, orgulhoso por demonstrar sua força física em seu principal número de espetáculo, e as correntes invisíveis com que ele mantém Gelsomina presa a ele. Ele a conserva próxima, não como uma assistente de espetáculo, mas como uma escrava, uma vez que não considera seus sentimentos de mulher, desejosa de seu amor, ou de ser humano, que procura seu lugar no mundo. Zampanò não respeita sua individualidade e inteligência, nem como pessoa, nem como artista, usando castigos físicos se ela o desagradar. No entanto, sabemos que as correntes de Zampanò não são chumbadas, elas possuem elos encaixados justamente para possibilitar seu número de força física que finge rompê-los e, sendo assim, também poderiam possibilitar a libertação de Gelsomina - mas isto só aconteceria se ela tivesse forças suficientes para se afastar dele.

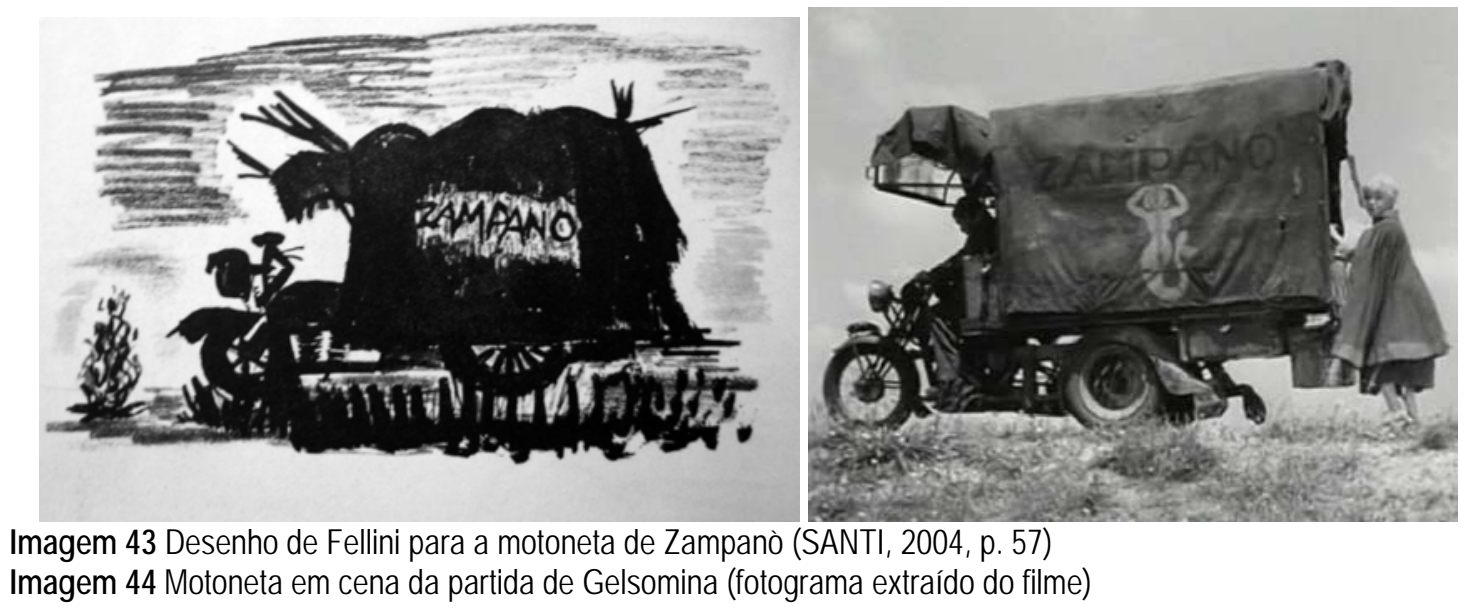

A caracterização de Zampanò foi muito eficiente e expressiva contribuindo muito para a construção deste perfil do personagem, tanto nos figurinos usuais como naqueles especiais, das apresentações. 


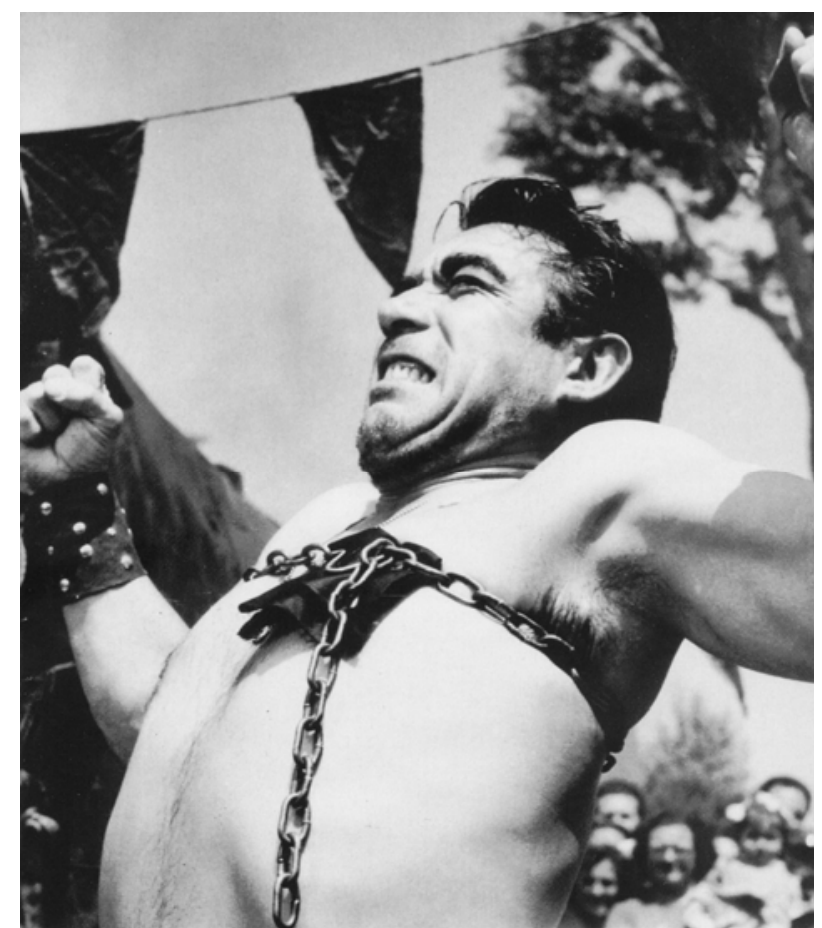

Imagem 45 Zampanò explode as correntes com a expansão de seus pulmões (WIEGAND, 2003, p. 48)

Zampanò usualmente veste uma blusa de lã canelada, escura, sobreposta por uma jaqueta de couro. Desde os desenhos de Fellini, como podemos ver na figura acima, a jaqueta já parecia sólida e impenetrável, como o personagem. Sua calça é escura, parece ter o mesmo tom da jaqueta; usa botas com cadarço, de estilo militar, usadas pelo lado de dentro da calça; gorro de lã cinza claro.

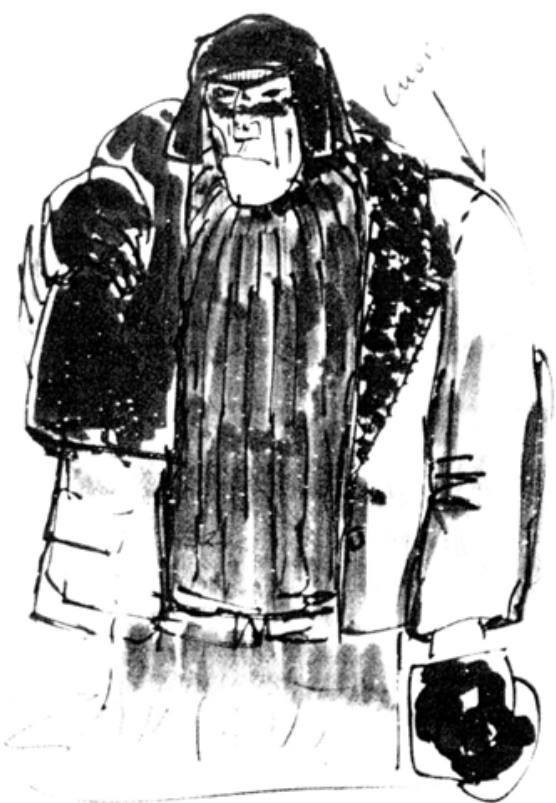

Imagem 46 Desenho de Fellini para o personagem de Zampanò (SANTI, 2004, p. 57) 


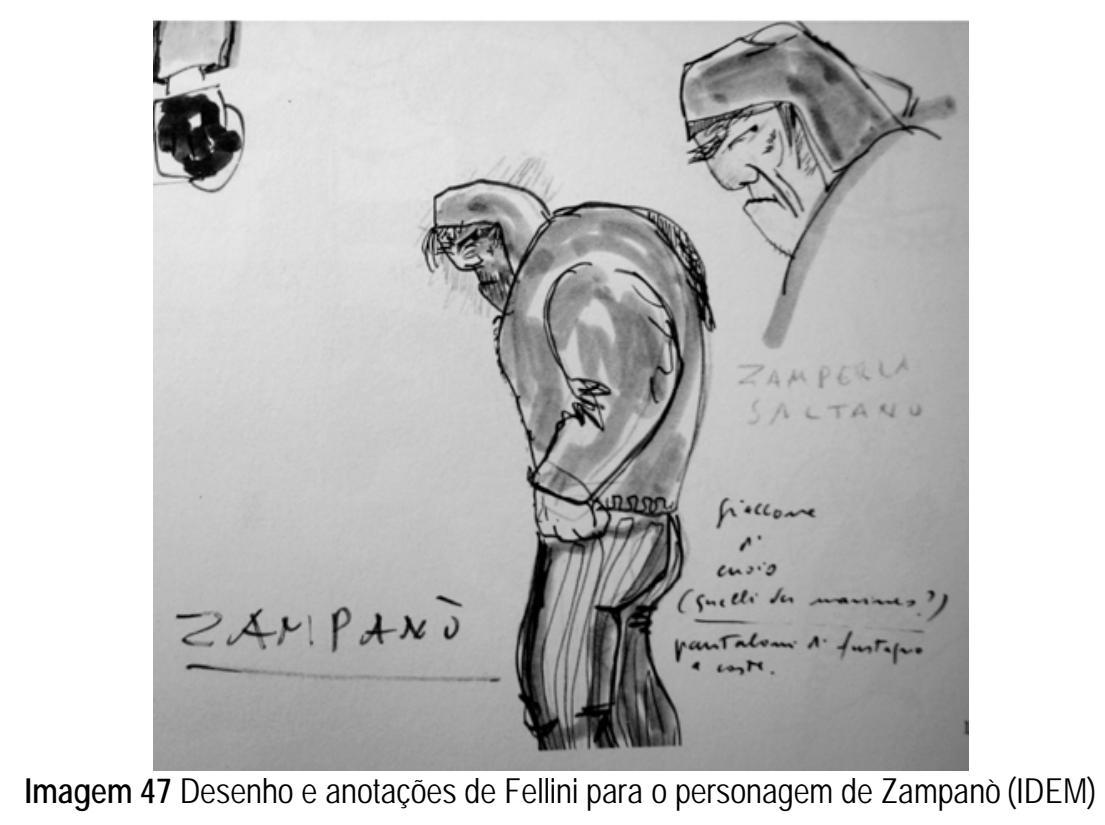

Nas apresentações, para o número das correntes - além das próprias, envolvendo seu peito nu - usa a mesma calça com um cinturão alto, de couro, com tachas. Usa braceletes que seguem o mesmo padrão do cinturão, são largos nos punhos, de couro, com tachas, e braceletes de couro, lisos, colocados nos dois braços, só que mais próximos dos ombros. Todos estes acessórios ajudam a identificá-lo com um bárbaro, destemido e possuidor de grande força física.

Além dessas duas roupas citadas, no dia do casamento no campo, Zampanò conversa com uma velha camponesa viúva que lhe serve o almoço. Ambos são rudes nos modos, golpeiam a comida com a colher para dentro das bocas que mastigam meio abertas ao mesmo tempo que falam. Este mesmo tom animalesco dos dois continua quando, após certa negociação, interrompem o almoço e Zampanò desce com a camponesa até o celeiro para fazer sexo com ela em troca de um terno do seu falecido marido.

Trata-se de um terno completo, preto, com riscas de giz (em oposição a Gelsomina, as listras são verticais e não horizontais, finas e não largas) que fica bastante imponente na figura corpulenta de Zampanò, de certa forma impenetrável como o traje da jaqueta, mas empresta também um ar respeitável e inteligente, nada compatível com sua figura. 


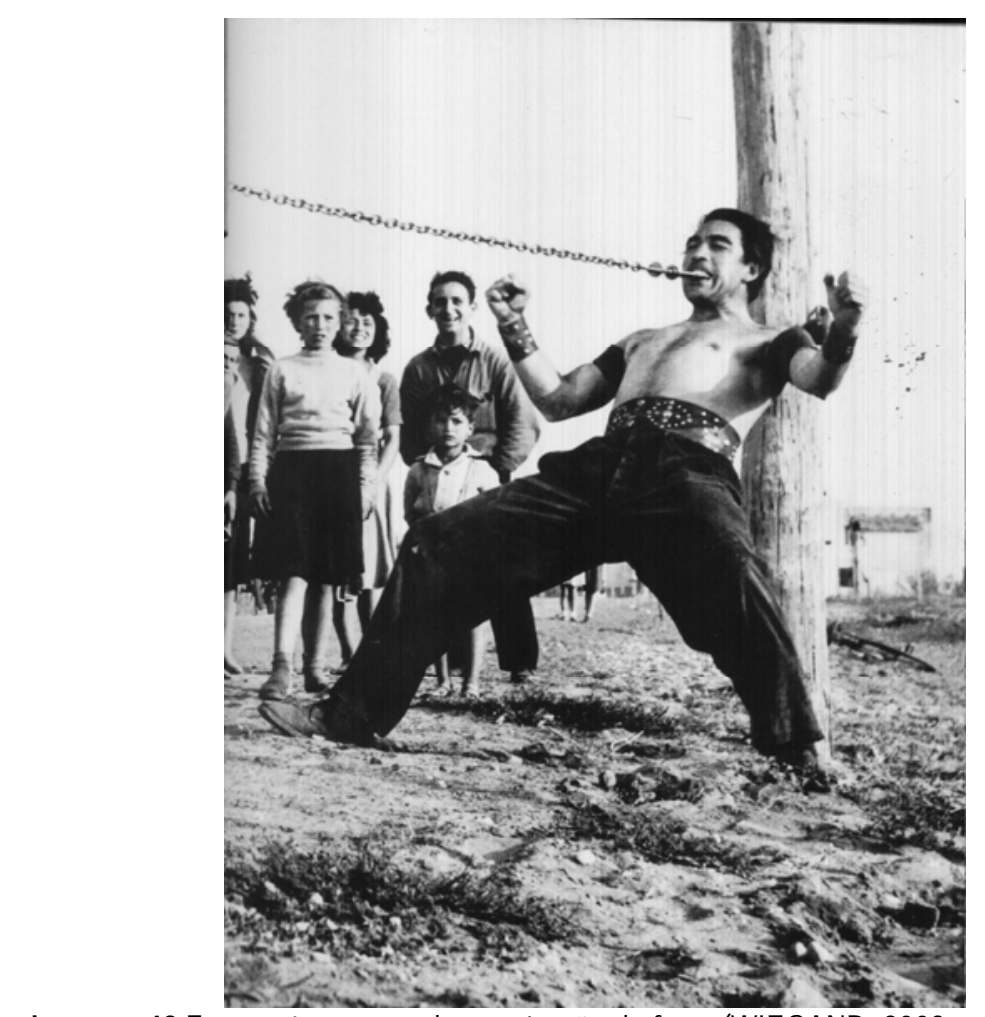

Imagem 48 Zampanò em uma demonstração de força (WIEGAND, 2003, p. 45)

Outros detalhes da caracterização que complementam o seu caráter são a barba por fazer, a feição sempre séria, com sobrancelhas grossas e quase sempre contraídas, formando uma ruga vertical na fisionomia, reveladora do humor tão severo, comum a Zampanò. O queixo deslocado ligeiramente para frente também garante um aspecto meio gutural ao personagem (forte e bruto como um homem das cavernas, não muito evoluído no quesito intelectual). E o timbre grave de sua voz também se soma aos outros aspectos intimidadores de sua pessoa.

\section{II matto ou o Louco}

Este personagem, o Louco, como fica conhecido, entra na história quando muito já havia sido desenvolvido. Gelsomina já havia percebido a extensão da tirania de Zampanò e decidido seguir sozinha quando vê o equilibrista pela primeira vez. Mais tarde, quando se encontram no circo e ela já está de novo sob o domínio de Zampanò, é ele o responsável por mostrar o quanto as pessoas podem estar, se quiserem, acima de todos os obstáculos, 
de todas as injustiças. O quanto podem fazer a vida ser maravilhosa, mesmo com todas as intempéries do caminho. Surge novamente a possibilidade de abandonar Zampanò, mas agora, definitivamente.
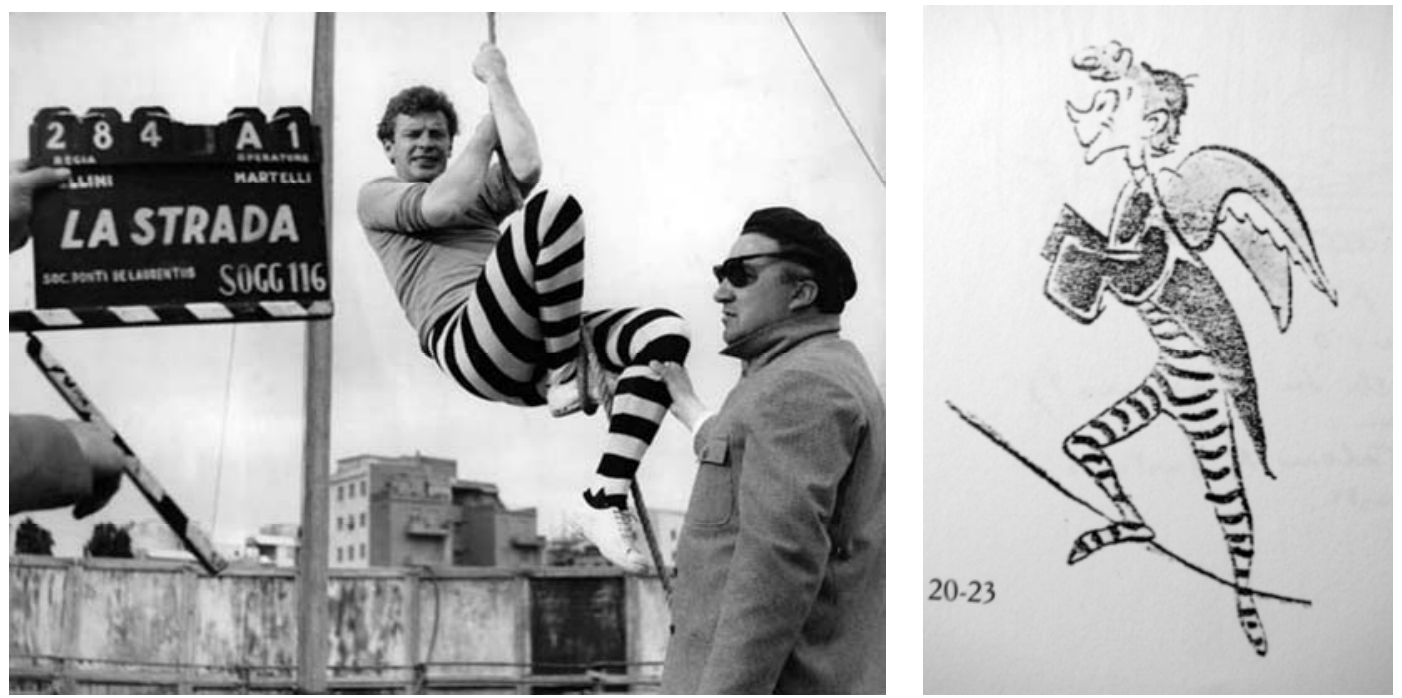

Imagem 49 Fellini com Richard Basehart no set de filmagem de La Strada (WIEGAND, 2003, p. 54 e 55) Imagem 50 Desenho feito por Fellini para o personagem Louco (SANTI, 2004, p. 58)

As atividades de equilibrista, palhaço e violinista conferem muito mais que exímio talento artístico ao Louco. Conferem uma sensibilidade apurada que ligam-no a elementos leves e poéticos tanto quanto Gelsomina. O Louco está ligado à música, à alegria, ao riso, ao equilíbrio físico e emocional e intuição divina.

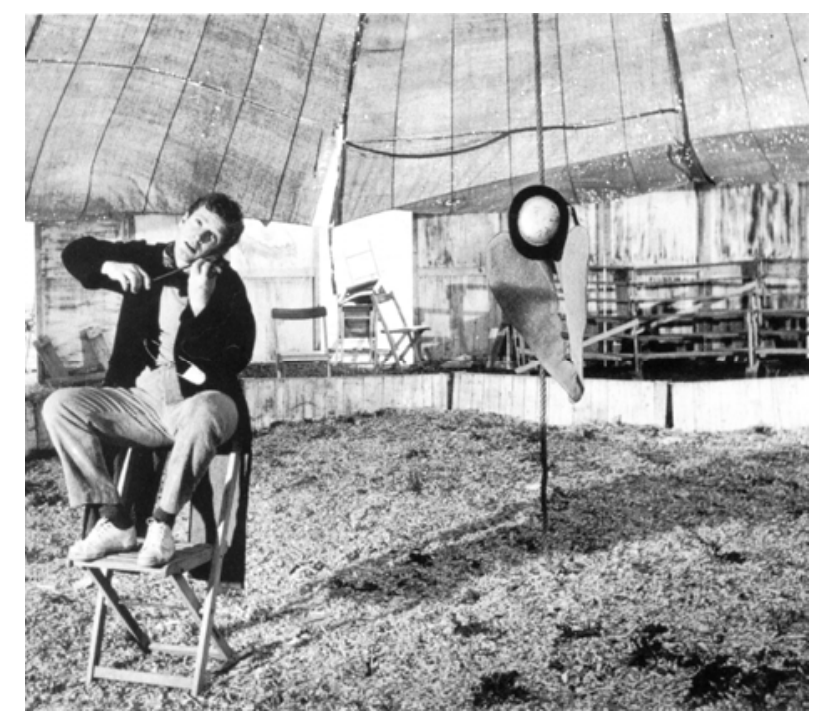

Imagem 510 Louco toca o tema de Gelsomina em seu pequeno violino (WIEGAND, 2003, p. 53)

O fato dele viver se equilibrando sobre uma corda bamba a vários metros de altura remete à mínima importância dada por ele aos riscos de viver. Ele preocupa-se apenas com a intensidade de sua vida. Por isso mesmo é que 
quando todos temem Zampanò, ele é o único que o provoca e tem coragem para desafiá-lo. O Louco pressente a brevidade de sua vida, (conforme o que ele diz a Gelsomina durante a conversa que têm no dia em que Zampanò está preso, que podia bater com a cabeça qualquer dia desses e morrer).

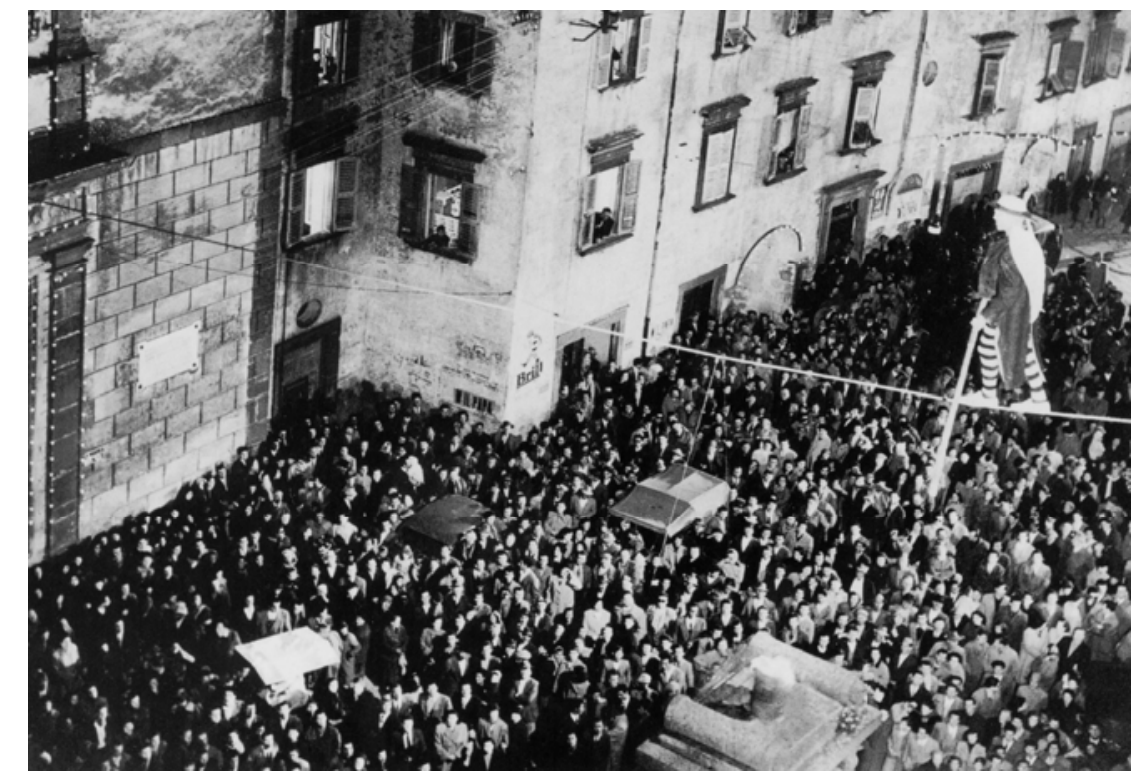

Imagem 52 O Louco sobre a corda bamba a vários metros de altura (IDEM)

De humor sempre elevado, o Louco poderia ser visto como uma alegoria de leveza e da própria alegria, aquela que Zampanò, ao contrário, extingue de todo lugar por onde passa. O Louco acaba morrendo por acidente. Num rompante de Zampanò, um estúpido golpe impelido por suas pesadas mãos, faz com que o frágil personagem padeça de repente.

Quanto ao aspecto externo do personagem, ele é desenvolvido coerentemente ao aspecto interno. Não é truculento como Zampanò: é um homem magrinho, pequeno e leve como um pássaro, delicado, sem tanta força nos músculos, mas muito ágil e habilidoso.

Os figurinos usados por ele são basicamente dois: um usual e outro para as apresentações. No entanto, na maioria das vezes que o vemos ele usa o traje das apresentações ou, pelo menos, a maior parte das peças que o compõem. Sua roupa mais normal é vista apenas no dia de sua morte, quando o encontramos à beira da estrada consertando seu carro. 


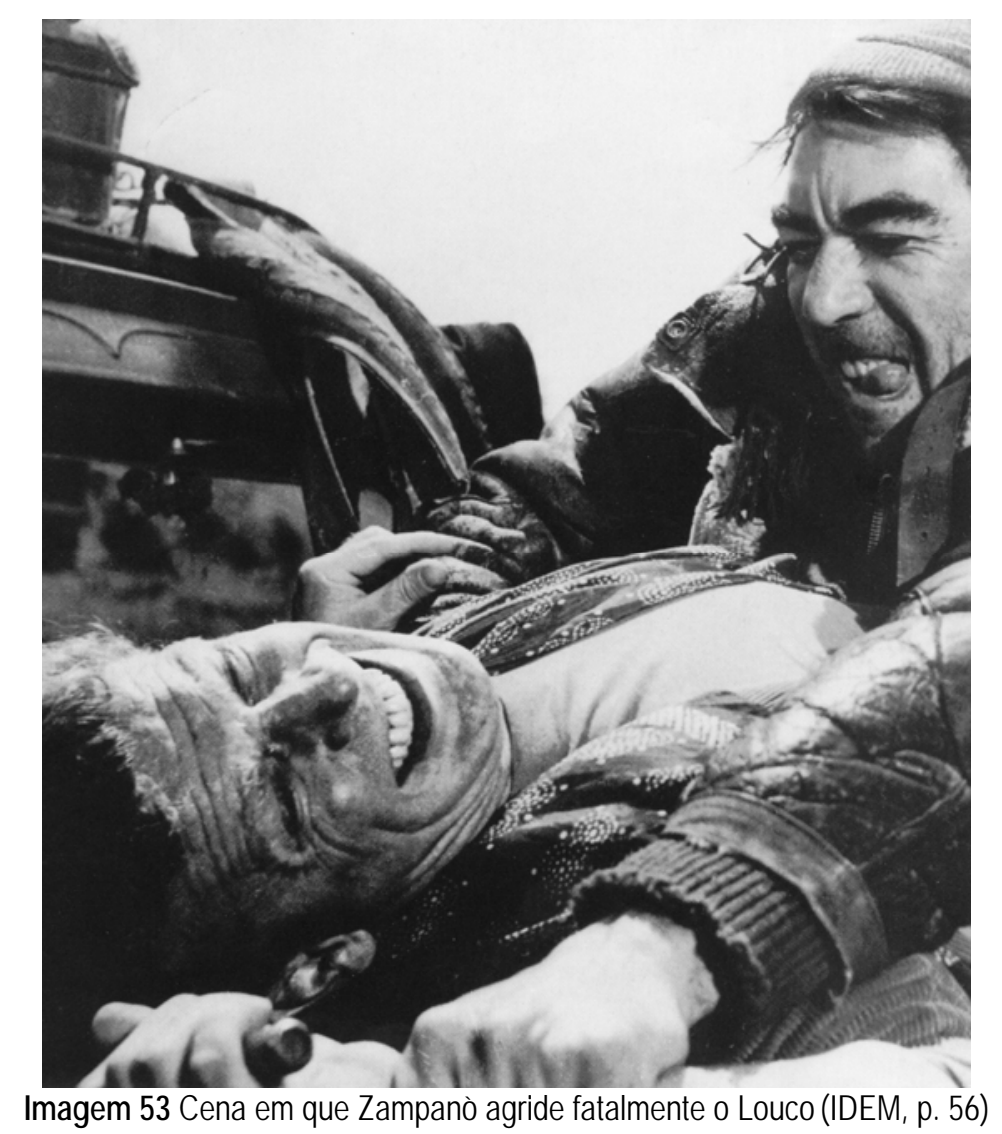

Por isso mesmo, a importância de seu traje de palco pode ser ainda maior. Ele usa uma calça justa de malha, permitindo-lhe maior mobilidade, com listras largas em preto e branco (no mesmo padrão da blusa de Gelsomina); tênis brancos de amarrar do tipo "keds" (fazendo-nos lembrar também dos tênis de Gelsomina); blusa de malha cinza sobreposta por um casaco preto, longo apenas nas costas, indo quase até o tornozelo e apresentando uma fenda no meio; um alfinete gigante que às vezes é usado para "fechar" o casaco; gola larga de palhaço arrematada por uma gravata borboleta preta; um par de asas de anjo, brancas, simples, de armação preenchida por tecido; um chapéu redondo de abas curtas semelhante a um chapéu coco, cujas abas são pretas e a parte que cobre a cabeça é branca.

As asas de anjo que ele usa podem identificá-lo a um Putto $^{24}$ e, mais uma vez o ligam ao caráter da leveza, mas também lhe conferem aspectos

\footnotetext{
24 "Putto (putti, no plural) é um termo que, no campo das artes, se refere a um menino nu, quase sempre de sexo masculino e representado frequentemente com asas. $O$ termo deriva do latim putus. No campo da história da arte, foi retomado noutras línguas a partir do italiano" Acesso em 4 de setembro de 2009. in http://pt.wikipedia.org/wiki/Putto
} 
divinos, espirituais. Ele parece saber de sua missão nesse mundo e alerta Gelsomina para o fato de que todos têm a sua missão - e neste momento apanha uma pedrinha do chão e diz: "eu não sei para que serve isto, mas certamente serve para algo... se ela é inútil, tudo mais é inútil, até mesmo as estrelas". O Louco poderia ser o "anjo da guarda" de Gelsomina, tentando salvá-la de Zampanò e dela própria, que precisa estar mais atenta a fazer mais por si mesma e por sua independência. Além disso, há também a consciência do Louco a respeito de sua própria morte (ele diz saber que qualquer dia pode bater a cabeça por aí e morrer de repente) como outra intuição divina. 


\section{PARTE B - ANÁLISE DA CONSTRUÇÃO DOS PERSONAGENS NO FILME JULIETA DOS ESPÍRITOS}

\section{Julieta dos Espíritos - O Filme}

Julieta dos Espíritos, de 1965, é o primeiro longa metragem a cores realizado por Fellini, por meio do qual ele pôde se entregar ao desafio de explorar todas as possibilidades expressivas do Technicolor, na tentativa de realizar algo que desde o princípio havia se anunciado a ele:

Julieta dos Espíritos é meu primeiro filme em cores verdadeiro (..) Já tinha feito um episódio em cores para Bocaccio 70, mas naquela ocasião não tinha enfrentado este problema, tratavase sobretudo de uma necessidade externa ditada pelo filme em seu todo (os outros episódios eram em cores), e eu me adaptei por uma espécie de coerência à qual, somado tudo isso, me sentia estranho. Com Julieta dos Espíritos, no entanto, pela primeira vez as cores apareceram como um problema totalmente expressivo, as primeiras imagens do filme apareceram para mim em cores, a história, a estrutura, o sentimento, são determinados e só vivem por intermédio das cores, e portanto só as cores podem contá-los, traduzi-los, expressá-los. (FELLINI, 2004, p. 131)

Fellini também sofreu grande influência das teorias do psicanalista Jung, do qual era grande admirador, levando em conta sonhos e imagens arquetípicas, que se apresentam com enorme força nesta película - como a visão da mãe, cujo modelo de perfeição é inacessível, as visões de apelo sexual, de auto-sacrifício, de decadência moral e de repressão religiosa materializando as emoções de Julieta. Para tornar mais clara a definição de arquétipos, Jung afirma:

(...) a maneira pela qual os arquétipos aparecem na experiência prática são a um tempo imagem e emoção. E só podemos nos referir a arquétipos quando estes dois aspectos se apresentam simultaneamente. 
(...) Mas desde que muitas pessoas pretendem tratar os arquétipos como se fossem parte de um sistema mecânico, que se pode aprender de cor, é importante esclarecer que não são simples nomes ou conceitos filosóficos. São porções da própria vida - imagens integralmente ligadas ao indivíduo através de uma verdadeira ponte de emoções. Por isso é impossível dar a qualquer arquétipo uma interpretação arbitrária, (ou universal); ele precisa ser explicado de acordo com as condições totais de vida daquele determinado indivíduo a quem se relaciona. (JUNG, 1964, p. 96)

As linguagens, do sonho e da arte, parecem mesmo muito consonantes, pois ambas transformam em imagem o que antes era apenas idéia, pensamento, palavra (RIVERA, 2008, p. 21). Nos sonhos, assim como no cinema, trata-se de representar figurativamente algo que é abstrato, unindo assim o discurso e o sensível, como concorda Fellini:

No sonho a cor é a idéia, o conceito, o sentimento, como uma grande pintura. (...) Quem sonha pode ver um campo vermelho, um cavalo verde, um céu amarelo, e não são absurdos. São imagens intrínsecas do sentimento que as inspira. (FELLINI, 2004, p. 131)

Porque Fellini compõe suas imagens de maneira pictórica, é que consegue oferecer uma nova dimensão, muito mais intensa, à expressão e à interpretação da obra - livre da preocupação naturalista. Tal rigor se nota nos cenários e figurinos minuciosamente elaborados traduzindo perfeitamente cada um dos personagens e seus universos.

O filme nos apresenta Julieta, uma mulher de cerca de 40 anos, excelente dona-de-casa, casada com Giorgio, um "relações públicas" bem sucedido. Sua vida parece ser perfeita, moram numa casa grande e bonita, cercada por natureza - um bosque e uma praia. No entanto, o casamento não parece ir bem e Julieta está cada vez mais insegura consigo mesma, atormentada por suas lembranças e pavores. 
Desejosa de paz e de amor, Julieta é obrigada a enfrentar seus medos personificados por seus sonhos e alucinações persecutórias. Um enfrentamento que, ao final, Ihe proporciona conhecer as qualidades que the são próprias e lhe dá a coragem e o ímpeto necessários para desejar seguir em frente e olhar o mundo com olhar renovado.

Este filme foi considerado pela crítica da época a versão feminina de Oito e Meio, uma vez que, tanto num quanto noutro, os protagonistas são obrigados a se defrontar com seus medos. No entanto, em Julieta dos Espíritos, este confronto é muito mais impactante, porque é perceptível inclusive imageticamente. Os medos afloram da protagonista e tomam forma ao redor dela, ganham vozes. Alguns bons exemplos disso estão na segunda metade do filme - quando Julieta vai se entregar aos prazeres de um encontro amoroso com o jovem e lindo rapaz no quarto de Susy, vê a imagem da amiga morta dos tempos de colégio, vigiando-a e repreendendo-a; quando Julieta já está em casa, no dia seguinte, arrumando-se para encontrar os amigos que a esperam no jardim, vê novamente a imagem dessa amiga morta, caída no chão do banheiro. Quando Julieta vai acudi-la, vê que ela transforma-se subitamente na figura de Susy, ou da bailarina de circo que fugira com seu avô; já no jardim, enquanto tenta concentrar-se em alguma conversa, Julieta escuta vozes e começa a ver figuras humanas espalhadas por todo canto: o reitor do colégio com cabelos vermelhos e sobrancelhas repressoras, mulheres nuas e sensuais que a encaram, a amiga de colégio queimando numa grelha, as freiras do colégio andando todas em fila, perseguindo-a, entre várias outras imagens. $\mathrm{O}$ invisível se torna visível, audível, palpável.

Quando comecei a pensar em Julieta dos espíritos, só vi uma possibilidade de saúde na fantasia desenfreada, na leveza de um jogo que pudesse propor certas transparências aqui e ali. Não se poderia fazer um filme sobre os sonhos em abstrato, prescindindo da personalidade do sonhador. (IDEM, p. 130)

Aproveitando este depoimento do diretor, pode-se colocar também que esta, como algumas outras obras de Fellini, constrói-se como um "monodrama". Tanto os sonhos, as alucinações, como os outros personagens e 
as ambientações, são construídos sob o ponto de vista do protagonista, a fim de tornar-nos perceptível os estados de espírito deste personagem e sua visão em relação às coisas. 


\section{Análise de Figurinos e Cenários dos personagens Julieta,}

\section{Susy e secundários}

Dada a extensão do filme Julieta dos Espíritos em relação à grande quantidade de personagens e a sua longa duração, a análise de figurinos e cenários será feita concomitantemente, seqüência a seqüência, selecionando um ou mais fotogramas de cada uma delas, para apresentar o estudo.

\section{Aniversário de Casamento:}

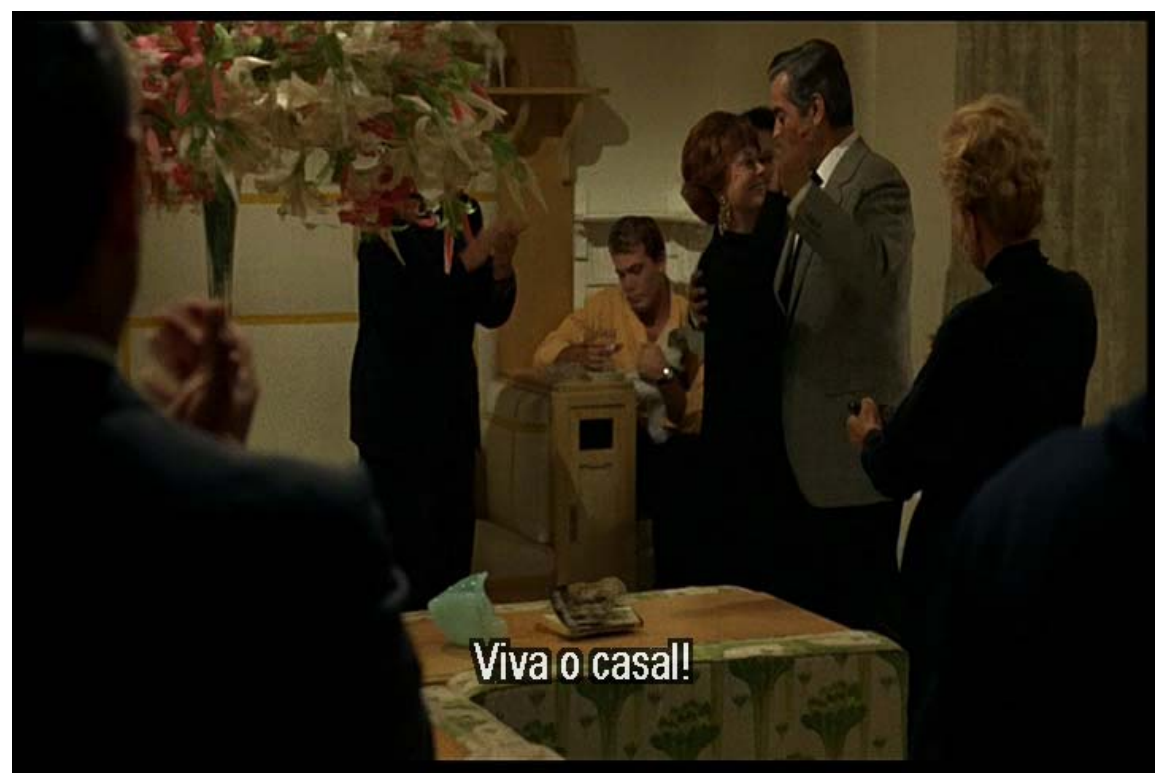

Imagem 54 Julieta e o marido, Giorgio, dançam ao redor de amigos na noite do aniversário de casamento ${ }^{25}$

O longa metragem se inicia com Julieta em sua casa à espera do marido, Giorgio, para comemorarem seu aniversário de casamento. Julieta o esperava com presente e jantar a luz de velas posto à mesa, mas Giorgio chega com diversos amigos, sem lembrar-se da data. É uma cena em que a falta de entrosamento do casal fica evidente, o clima é morno, não há nenhuma cor vibrante. Os tons usados são preto, bege, verde cáqui, laranja e rosa pálidos.

Tendo-se criado um constrangimento, resolvem fazer algo diferente e logo se inicia uma sessão espírita na sala, aproveitando a presença de um médium entre eles. Nesta sessão, surgem dois espíritos (recorrentes ao longo da trama): um que proclama "amor para todos" (Íris) e outro que parece

\footnotetext{
${ }^{25}$ Todas as imagens do filme Julieta dos Espíritos nesta análise são fotogramas extraídos diretamente do filme em questão.
} 
condená-lo, acusando uma das mulheres presentes de "vadia" e "meretriz" (Olaf).

Considerando que o evento se passa na casa de Julieta e, notando o estado esgotado em que ela se encontra assim que terminam as manifestações, esses dois espíritos parecem ter-se emanado da presença dela, ou pelo menos, parecem ser duas idéias que a perseguem. As idéias do amor e do cuidado são muito próprias deste personagem, e aparecem sempre de duas maneiras muito distintas - ou Julieta manifesta seu amor e seu cuidado sendo a maravilhosa dona-de-casa; ou personifica-se nas figuras de desejos sexuais reprimidos, no desejo de ser a amante incrível, tanto quanto de ser incrivelmente amada.

Ao mesmo tempo em que a proclamação de "amor para todos", presente num dos diálogos iniciais do filme (durante a sessão mediúnica), a agrada e parece-se muito com sua tônica dominante, ela só é completamente aceita se referir-se a um amor calmo, domesticado, "decente". Se referir-se a um amor em que haja liberação sexual, isto a amedronta e faz reviver uma série de juízos de valor moral próprios de sua formação excessivamente católica, criadora do conceito de pecado.

\section{Quarto de Julieta:}

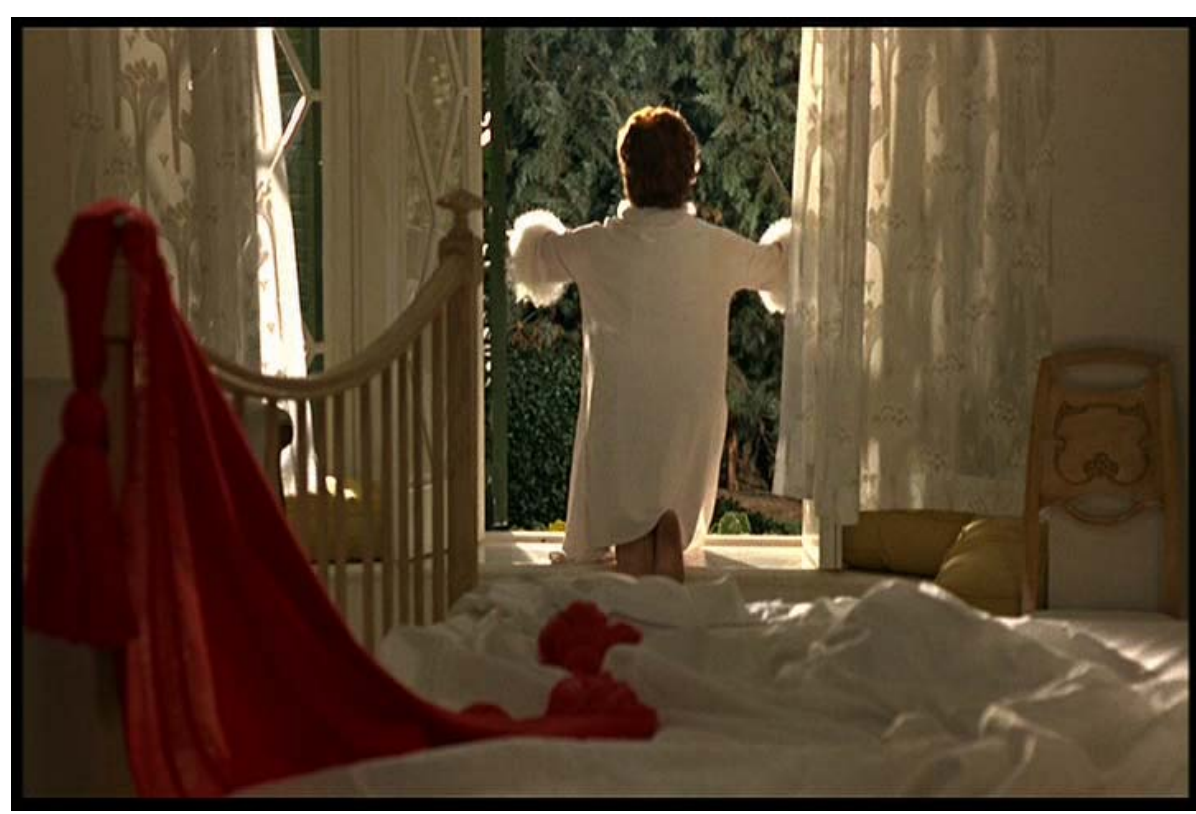

Imagem 55 Julieta abre a janela de seu quarto pela manhã 
$\mathrm{Na}$ manhã seguinte ao jantar, Julieta acorda envolvida pelos acontecimentos da noite anterior, pelas mensagens de amor trazidas pelo espírito feminino através do médium que estava entre os amigos de seu marido. Esta cena em seu quarto revela muito sobre sua personalidade clara, arejada. O quarto é branco nas paredes, nas cortinas e nos lençóis, os móveis são de madeira clara, de estrutura vazada, permitindo ver sempre o que está por trás. O branco aqui traz alegria, disposição e certa sensação de expectativa pelo que está por vir. Comunica-se muito bem com o verde que se vê no jardim lá fora.

Além do branco, há apenas um pano vermelho sobre a cama escorrendo em direção à personagem e à janela do jardim tomada pelo verde - aqui valoriza-se o contraste das duas cores complementares. As duas cores muito usadas durante todo o filme, principalmente para a figura de Julieta, expressam vitalidade - vermelho, cor de sangue e verde, cor natural das plantas. E se pensarmos na cor e no desenho do pano vermelho sobre a cama, sinuoso como uma serpente, logo associaremos a imagem à sexualidade reprimida de Julieta, desejosa por aflorar, e à sexualidade do marido, tão aflorada que o faz trair a esposa.

\section{Tenda de Julieta na praia:}

Nesta seqüência Julieta e sua vizinha Susy, personagens opostos já que, se encontram na praia, mas neste momento ainda não se conhecem formalmente, nem se tornaram próximas.

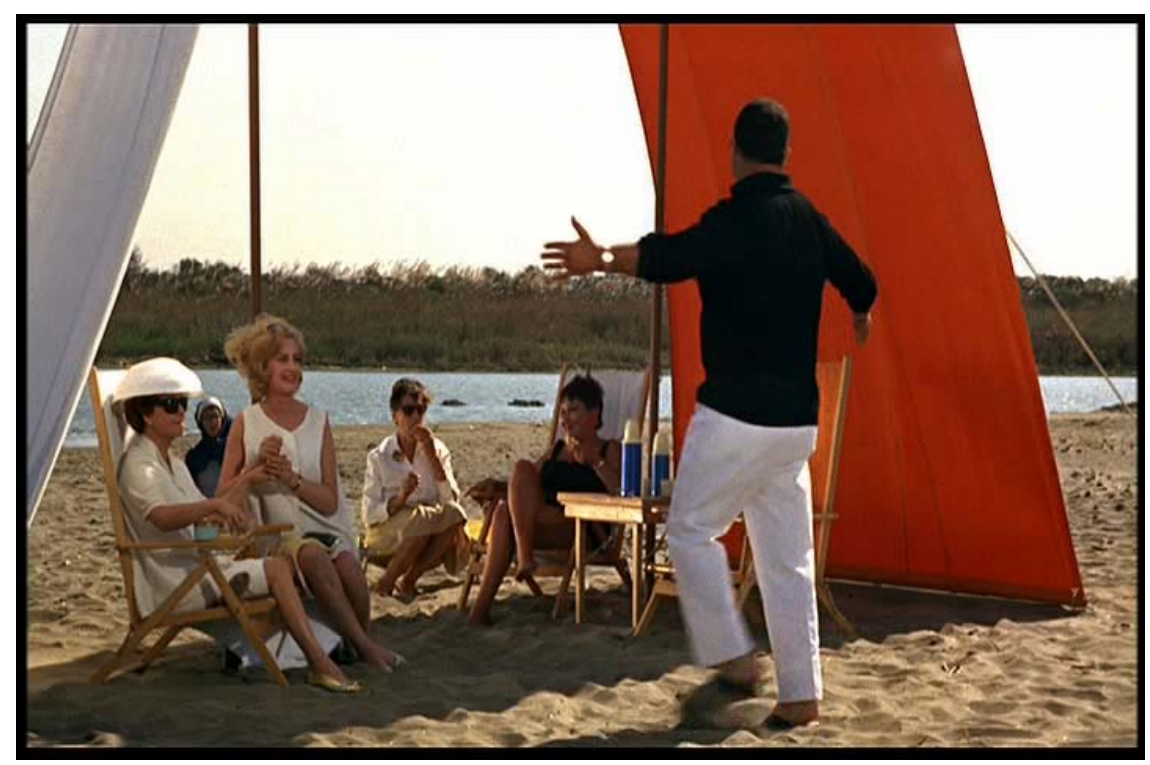

Imagem 56 Julieta e seus amigos na praia 
Aqui os figurinos usados são quase todos brancos, há apenas algumas peças pretas. A tenda de Julieta é branca e vermelha e possui traços retos e simples em sua estrutura. Não há espaço para rebuscamentos em torno de Julieta. Ela é simples, prática e elegante. Porém, não deixa de ter dentro de si algo que não se aquieta, algo que vibra em potência, assim como o caráter do vermelho, repetidamente usado em associação a este personagem - já o observamos na cena anterior, no pano vermelho que escore em direção à Julieta.

Outra associação recorrente, como apontarei em outras imagens, é o conflito cromático entre branco e vermelho, evidenciando a dualidade entre a pureza espiritual e o amor passional; o conflito interno de Julieta, respectivamente a mansidão do amor que vive com o marido e o desejo profundo de um amor pleno, arrebatador e recíproco.

Nesta mesma cena, Julieta cochila levemente na cadeira de praia e tem alguns pesadelos, que os quatro fotogramas a seguir ilustram. As imagens dos pesadelos parecem desconexas mas lembrando da influência junguiana de Fellini, podemos analisá-las mediante este referencial de psicanálise. Jung, resumidamente, dividiu a mente em três partes - a mente original, a mente consciente e a inconsciência. A mente original estaria repleta de energia psíquica primitiva; a mente consciente perdeu contato com uma porção da energia psíquica ao tentar racionalizar tudo e a inconsciência conservou as características primitivas que faziam parte da mente original. Assim, nossos sonhos nos expressam seus conteúdos por uma linguagem muito própria, a da natureza, incompreensível para nosso entendimento racional. Jung afirma que "a função criadora dos símbolos oníricos é uma tentativa de trazer a mente original a uma 'consciência avançada', ou esclarecida, que até então Ihe era desconhecida." (JUNG, 1964, p. 98) 


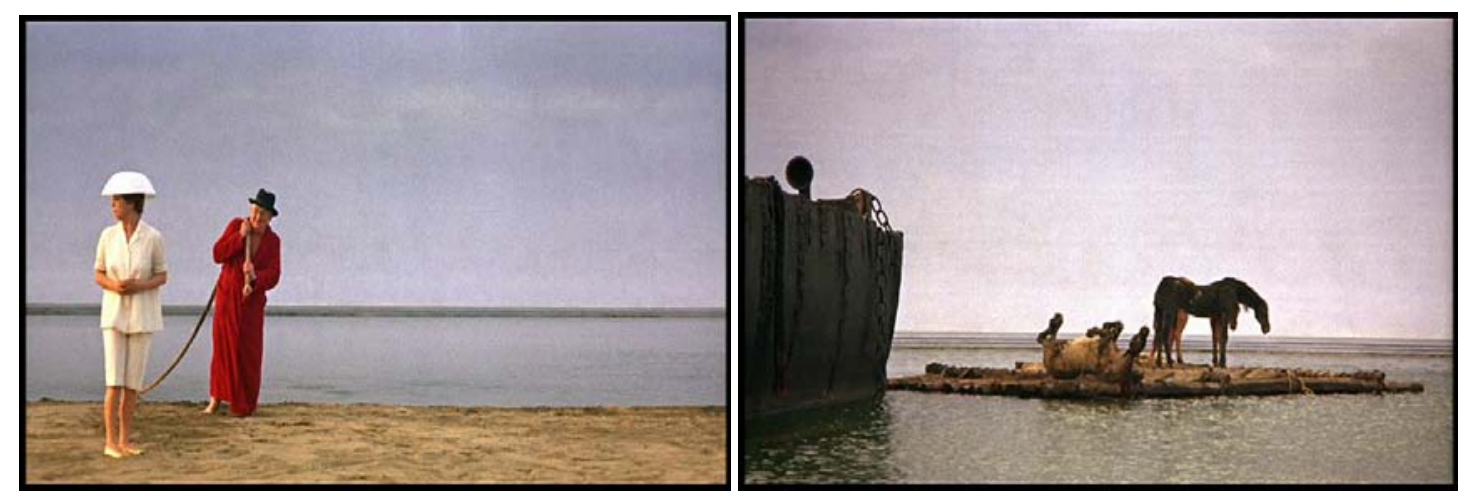

Imagens 57 e 58 Imagens do pesadelo de Julieta

Os pesadelos de Julieta então manifestam o que o seu inconsciente já percebera a respeito de seu casamento. Na sequência, os cavalos é que estão desprotegidos na jangada aberta, morrendo expostos às intempéries poderiam ser associados aos instintos livres em nossa sociedade, em nossa mente. O senhor de vermelho que vemos aproximar-se da praia é o detetive que conheceremos sequências adiante. Ele puxa por uma corda uma barca que parece antiqüíssima e pesada (pelo desenho da barca e pelas roupas do guardião a frente do plano em um dos takes), repleta de pessoas mais velhas e semi-nuas aparentando uma luxúria decadente - protegidas pela estrutura fechada, mantém-se vivas. Dentro desta barca também podemos ver o fotógrafo detetive, que é a única pessoa vestida na embarcação. Os dois personagens parecem envoltos neste universo de decadência, que parece simbolizar os casamentos hipócritas e cheios de traições - a função dos dois é perseguir e explorar este universo, de fato pesado e rançoso, e exibir seu terror aos interessados.

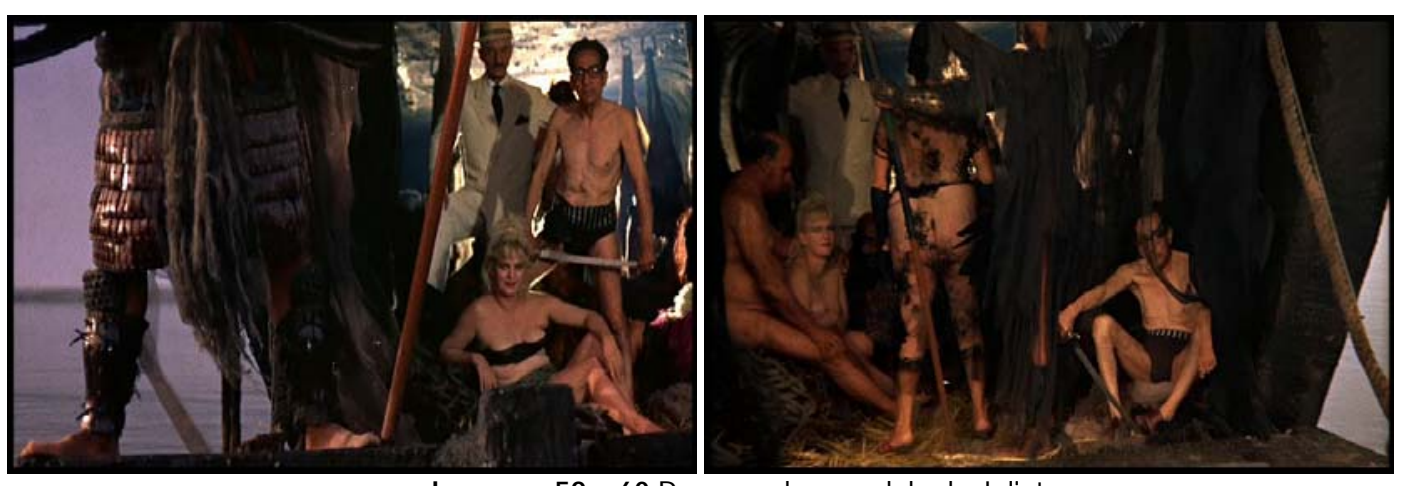

Imagens 59 e 60 Pessoas do pesadelo de Julieta 


\section{Tenda de Susy na praia:}

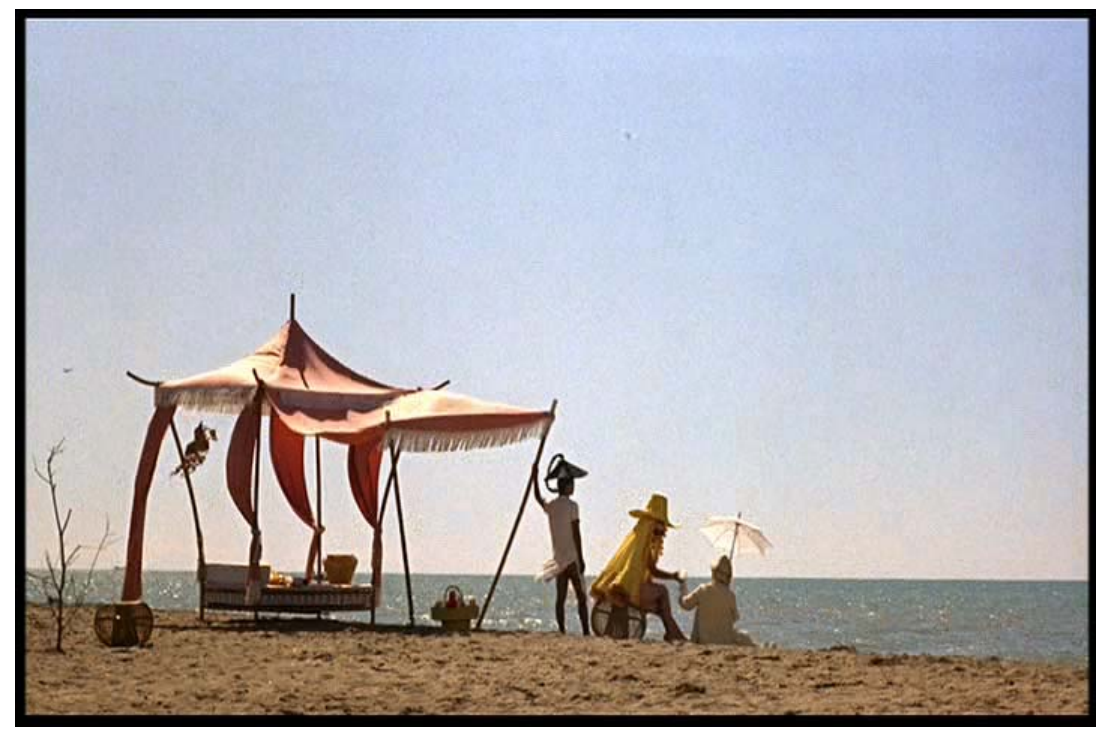

Imagem 61 Susy na praia com sua avó

A cor de Susy, a vizinha excêntrica, é o amarelo, cor muito associada à loucura na cultura ocidental. (Aqui vemos a sua tenda, durante a mesma seqüência em que vemos Julieta na praia). Susy usa um extravagante conjunto amarelo de chapéu com abas largas e capa acoplada, está acompanhando sua avó, que usa um vestido discreto em tom de amarelo pálido. Comparando as duas sentimos no tom de Susy muita vitalidade e, no tom da avó, sentimos como se o seu amarelo já houvesse sido desbotado pelo tempo, nele há uma serenidade própria da velhice. Neste quadro o amarelo se torna mais radiante pois é visto em contraste com os azuis do céu e do mar (amarelo e azul, o maior contraste segundo Kandinsky, conforme já apontado no tópico anterior).

Outra cor observada na cena é o vermelho da tenda, que tende ao laranja por conter uma porção de amarelo. É menos puro que o vermelho da tenda de Julieta, e a luz do sol refletida em sua superfície, faz com ele seja mais claro e perca assim um pouco do caráter vibrante da cor. Diferentemente da que é usada por Julieta, a de Susy possui franjas e um formato mais cheio de curvas. Os objetos usados por ela também seguem o mesmo padrão de diferenciação, não são usadas cadeiras usuais de praia, mas sim puffes orientais de palha vazados, em formato arredondado.

Susy não é casada e cultiva diversas aventuras amorosas que parecem divertir seu dia-a-dia. É exuberante, livre, colorida, o que se manifesta tanto em seus figurinos, como no cenário de sua casa, conforme abordaremos mais adiante. Este personagem jamais se nega um prazer, jamais se sacrifica. 
Julieta, mãe e irmãs no bosque:

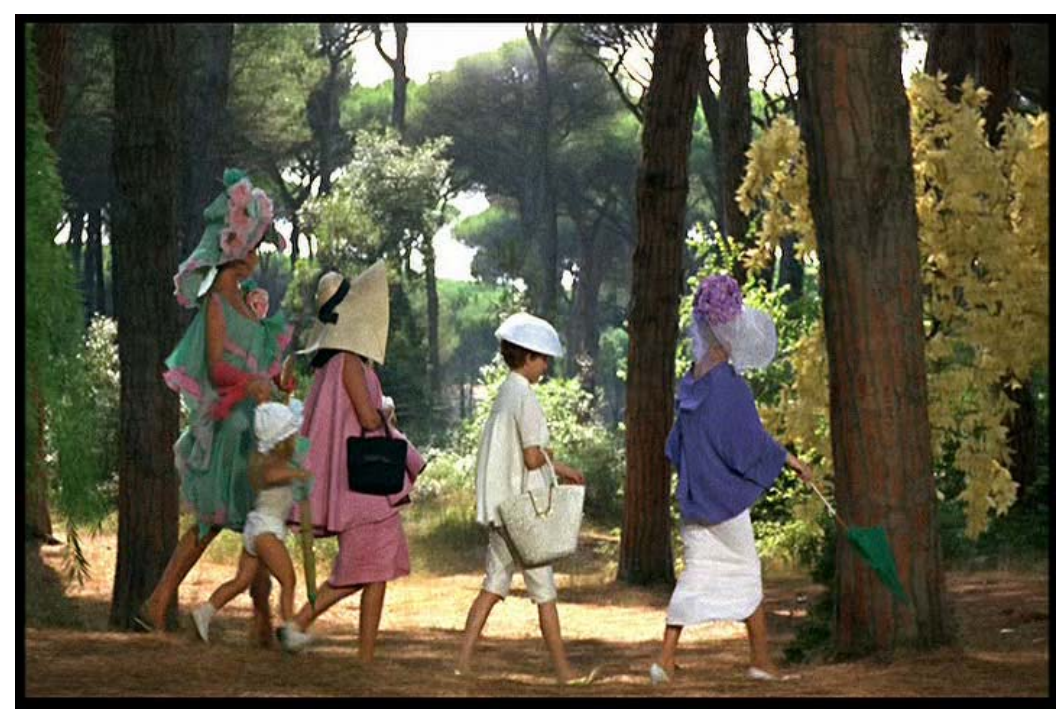

Imagem 62 Julieta encontra suas irmãs no bosque ao voltar da praia

Voltando da praia com as sobrinhas pelo bosque, Julieta encontra com sua mãe e suas irmãs. O figurino de Julieta sempre salta do fundo com sua brancura, principalmente porque aqui estão numa área de sombra. Percebe-se, com a unidade de cor na roupa de Julieta, com pequenos detalhes dourados, uma simplicidade e uma nobreza. As outras três mulheres usam cores vivas e delicadas, porém em formas muito rebuscadas que evidenciam sua afetação. São como pessoas que se valem da moda para mostrarem-se na sociedade mas que são incapazes de mostrarem como são verdadeiramente. Seus chapéus, concordando com este comportamento, parecem encobrir estrategicamente seus rostos, reforçando a idéia de que não se dão a conhecer, ao contrário de Julieta, que com sua brancura e simplicidade, denota transparência.

De um modo geral, como será possível observar, os figurinos de Julieta são sempre elegantes e discretos. Possuem um perfil menos rebuscado, sem excessos, limpo de detalhes supérfluos, não chamando a atenção mais para a roupa do que para sua própria personalidade. Ela é vaidosa, mas contida. Usa sapatos baixos por estar sempre cuidando da casa, das sobrinhas ou indo à praia.

\section{Café da manhã - Suspeita:}




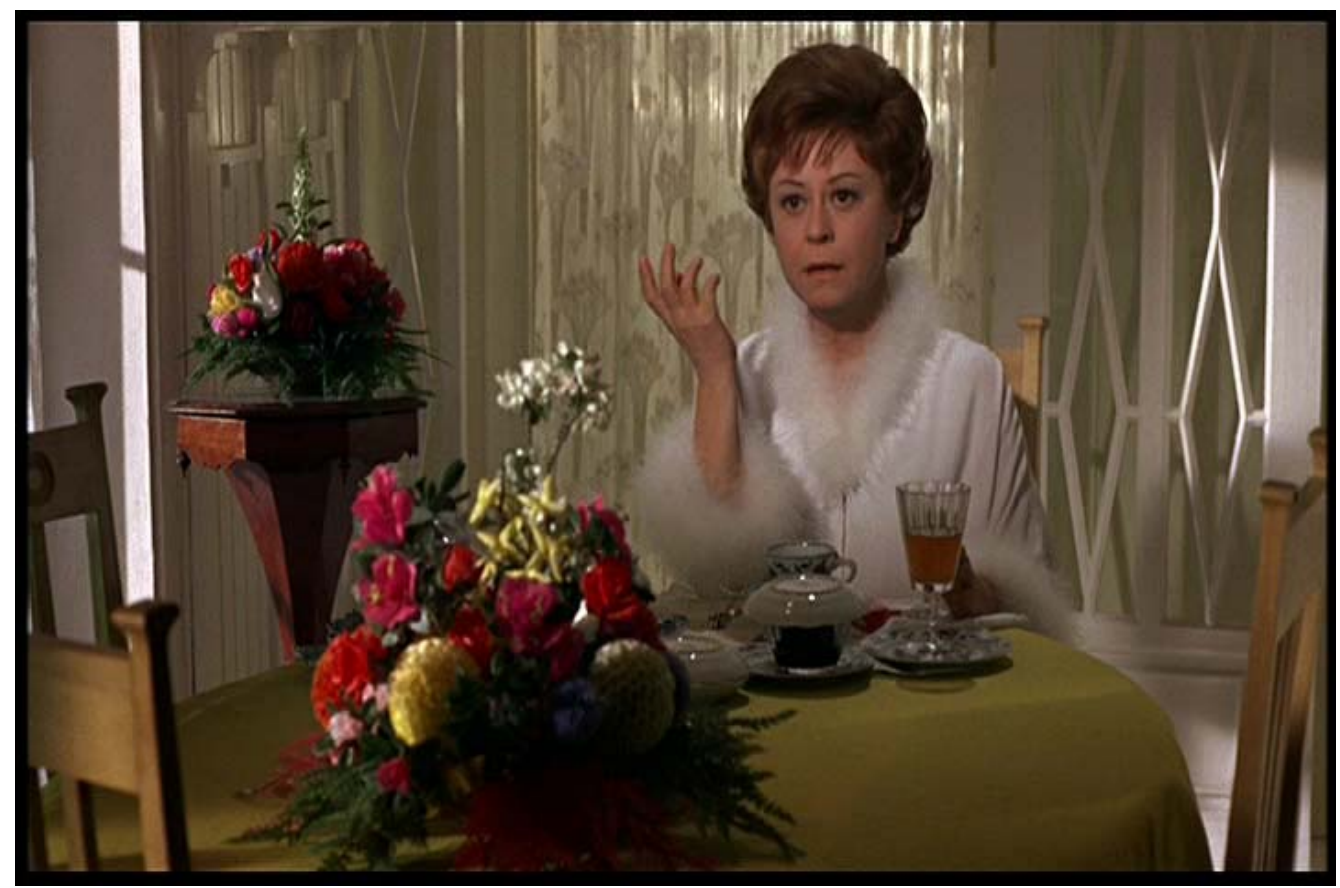

Imagem 63 Julieta indaga Giorgio sobre o nome "Gabriela" pronunciado por ele durante a noite

Julieta toma café-da-manhã após ter ouvido seu marido sussurrar durante a noite o nome de outra mulher. Ela suspeita que algo esteja errado e aqui esta sensação nos é dada através do tom verde amarelado que, ao contrário do verde puro, não remete a algo viçoso, mas a algo que está se estragando, o verde amarelado, ou o amarelo esverdeado, têm algo de doentio.

Nas flores sobre a mesa e sobre a pequena mesa lateral ao fundo, sobressai o vermelho, que entremeado com outro tom de verde mais escuro, se torna mais vibrante. O branco ao redor na sala ajuda a fazer com que o colorido das flores se espalhe pelo ambiente, contagie num movimento dispersivo. 


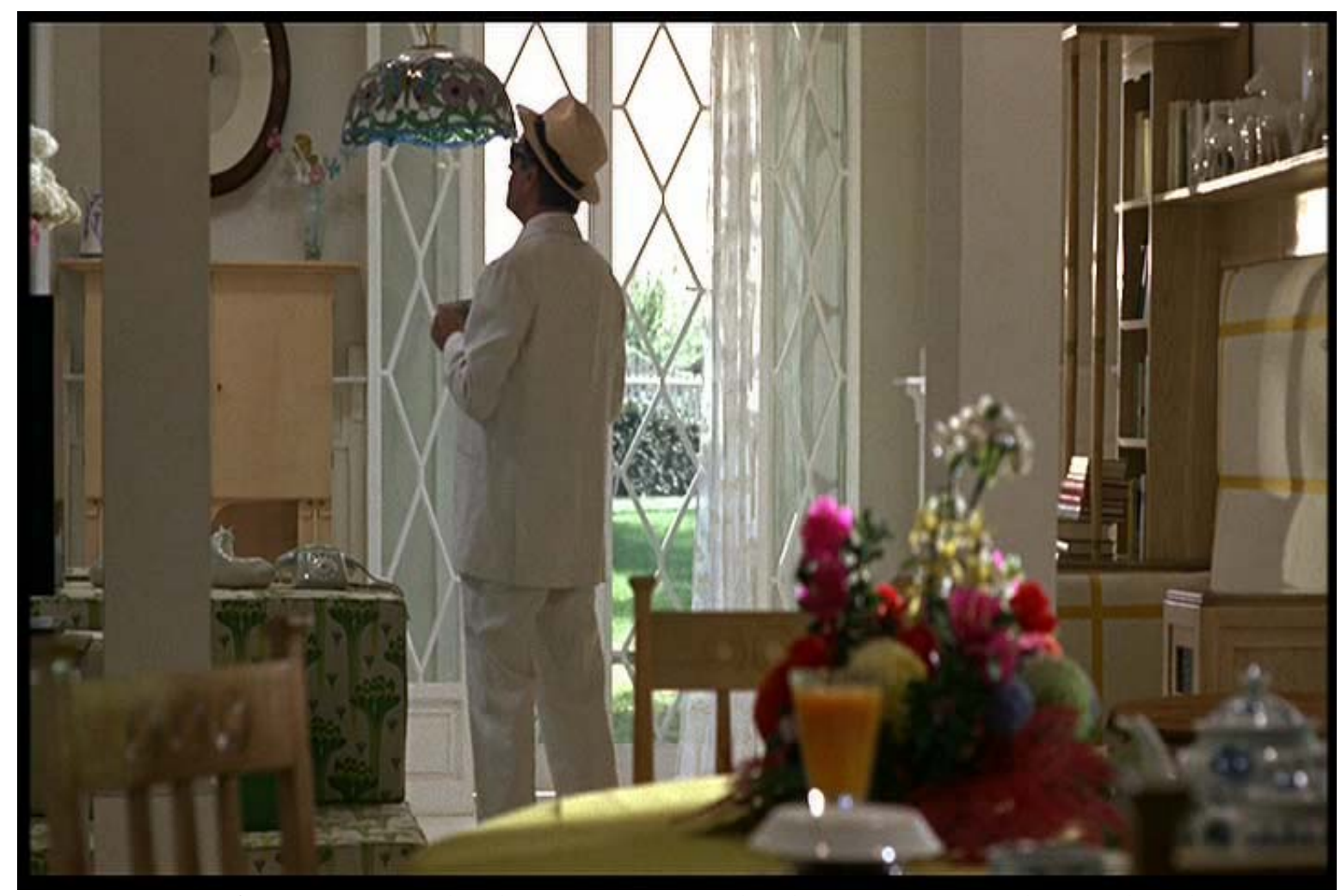

Imagem 64 Giorgio se esquiva de Julieta ao ser questionado sobre o nome sussurrado na madrugada

Ambos usam roupas brancas, o que sugere o momento de suspensão, de pausa para entender o que se passou e o que virá depois desta suspeita de traição. O branco, segundo Kandinsky, representa o silêncio, mas não aquele de morte, definitivo - um silêncio que dá espaço ao que está por vir.

\section{Convite para o encontro com o Brishma:}

Misturando as duas cores mais freqüentes nos figurinos de Julieta, o branco e o vermelho como pudemos observar nos fotogramas anteriores, chegamos em cor-de-rosa, utilizado num tom claro, expressa docilidade e doçura. 


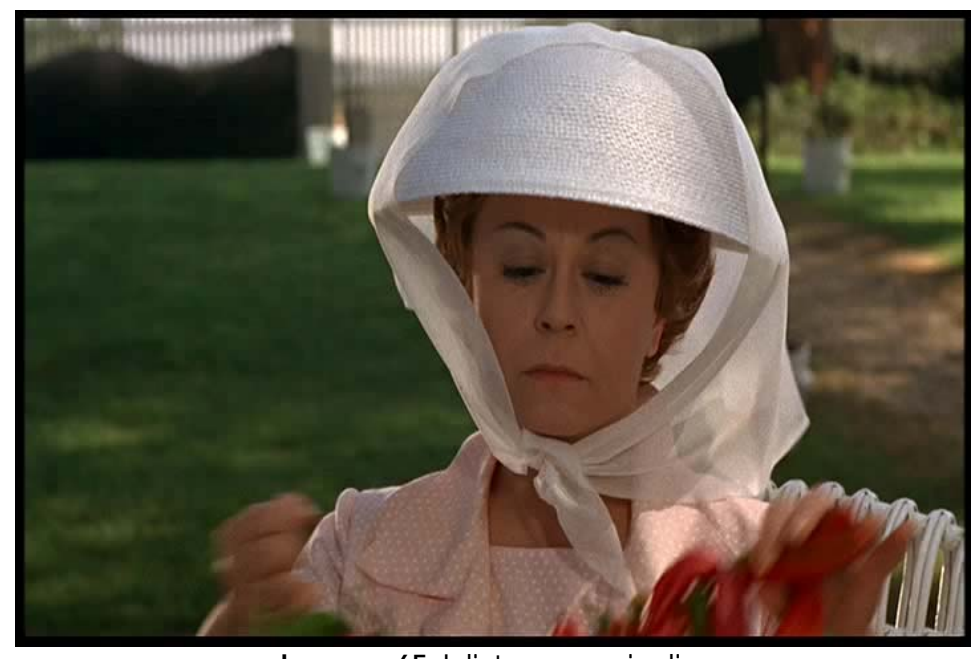

Imagem 65 Julieta em seu jardim

É a cena em que ela costura guirlandas de pimentões, desempenhando seu excelente papel de dona-de-casa enquanto tenta se convencer de que Giorgio tinha sido sincero ao negar conhecer a tal Gabriela, cujo nome ele sussurrava enquanto dormia na noite passada. $O$ branco e o vermelho responsáveis pela formação do rosa estão em quadro; no chapéu, no lenço e nos pimentões. O vermelho (e o rosa em menor proporção) por sua vez, contrasta com o verde do vasto gramado que a rodeia e se destaca ainda mais por causa disso.

Sobre a indumentária, um mesmo modelo de chapéu é usado por ela em

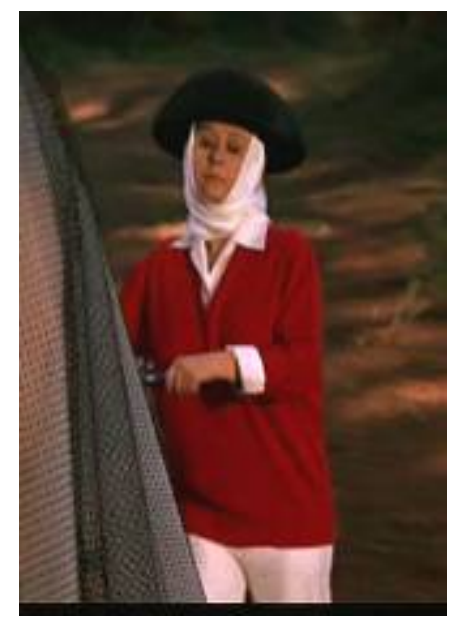

duas versões diferentes - este branco, e preto, na seqüência em que vai à floresta com Susy. Nas duas versões é todo arredondado para baixo, como que formando uma aura no alto da cabeça de Julieta, como a dos santos. Ao mesmo tempo, o formato arredondado e contido do chapéu pode traduzir também sua natureza reprimida. Sua maquiagem é simples e natural, não busca esconder nada. Imagem 66 Chapéu em versão preta do branco mostrado acima

Nos desenhos de Fellini para este filme, já podemos ver que ele pensava neste formato inusitado de chapéu para o personagem. $\mathrm{O}$ uso da cor vermelha também está presente, mantendo o estilo elegante e discreto de Julieta, ainda que o modelo do vestuário não corresponda exatamente ao observado na película. 


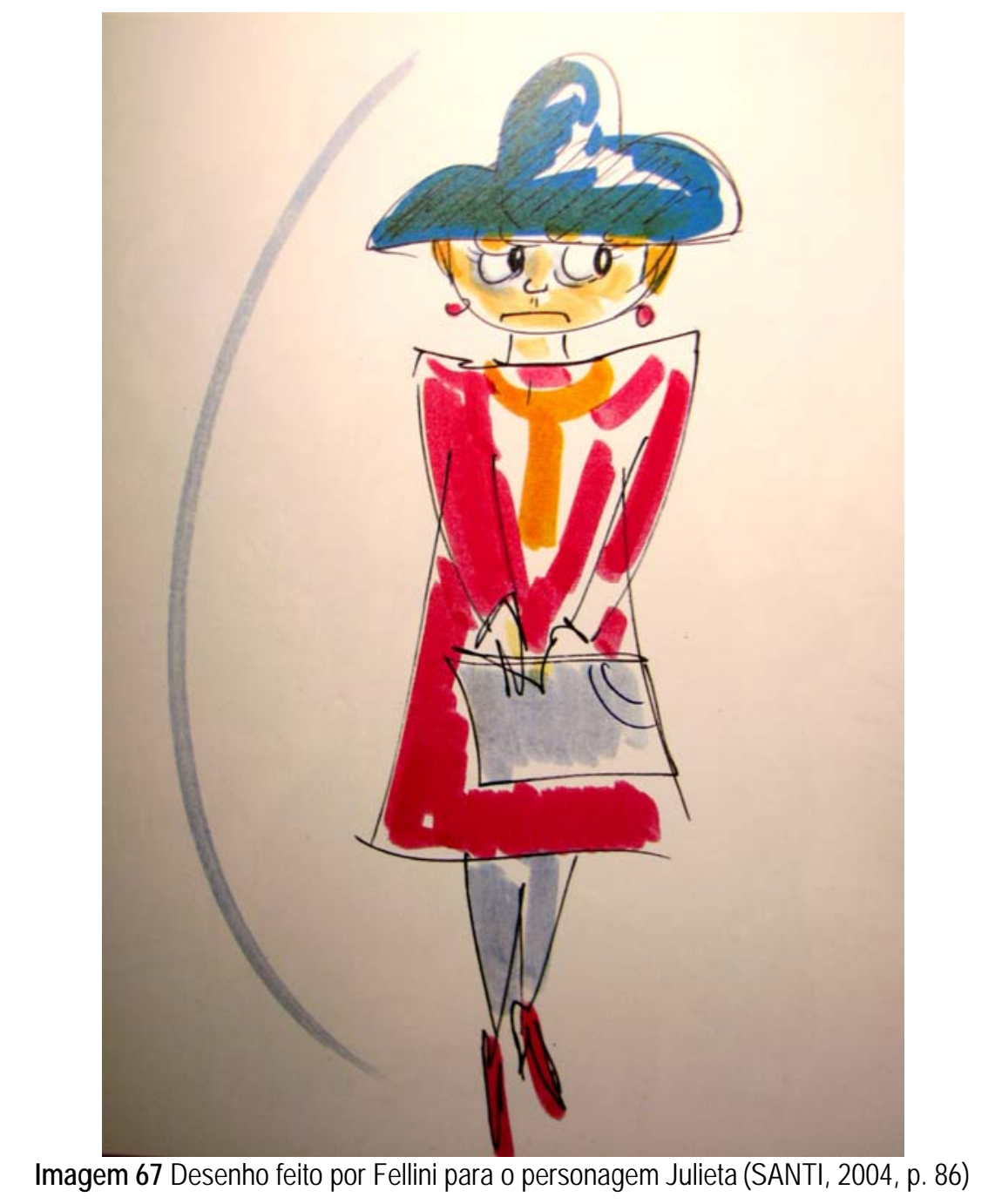

\section{Encontro com o Brishma:}

Nesta seqüência em que Julieta vai ao encontro do guru Brishma, a convite da amiga Val, Julieta usa um figurino de cores bastante contrastantes vermelho e verde. Este contraste lhe confere uma vibração marcante que combina com seu caráter e estado de espírito. Embora a protagonista esteja passando por um período de dúvidas em relação a seu casamento e sua postura na vida, é uma mulher profundamente amorosa e viva. Ela acaba indo ao encontro com o guru por insistência da amiga, mas muito porque está desesperadamente em busca de respostas para seus anseios.

Outro dado que podemos observar é que a mistura de vermelho e verde no espectro da "cor-luz" resulta em amarelo - cor de Susy por equivalência entre seu temperamento e as características atribuídas a esta cor, além das simbologias históricas, como a "loucura", por exemplo. Susy é o personagem oposto ao de Julieta, representa para a protagonista o que deve ser repelido, 
evitado. No entanto, talvez a força desse "amarelo", esteja em sua própria composição, ainda que de maneira velada.

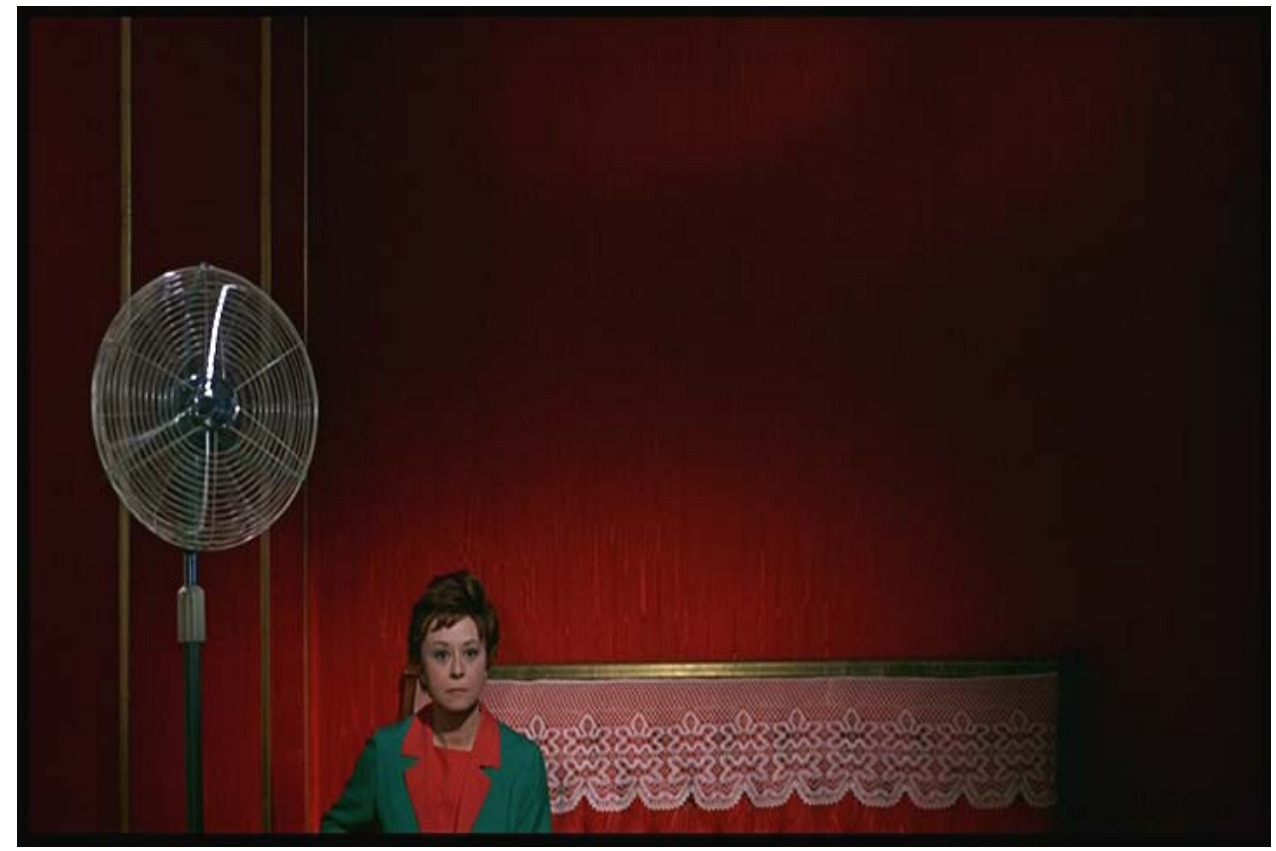

Imagem 68 Quarto do guru Brishma

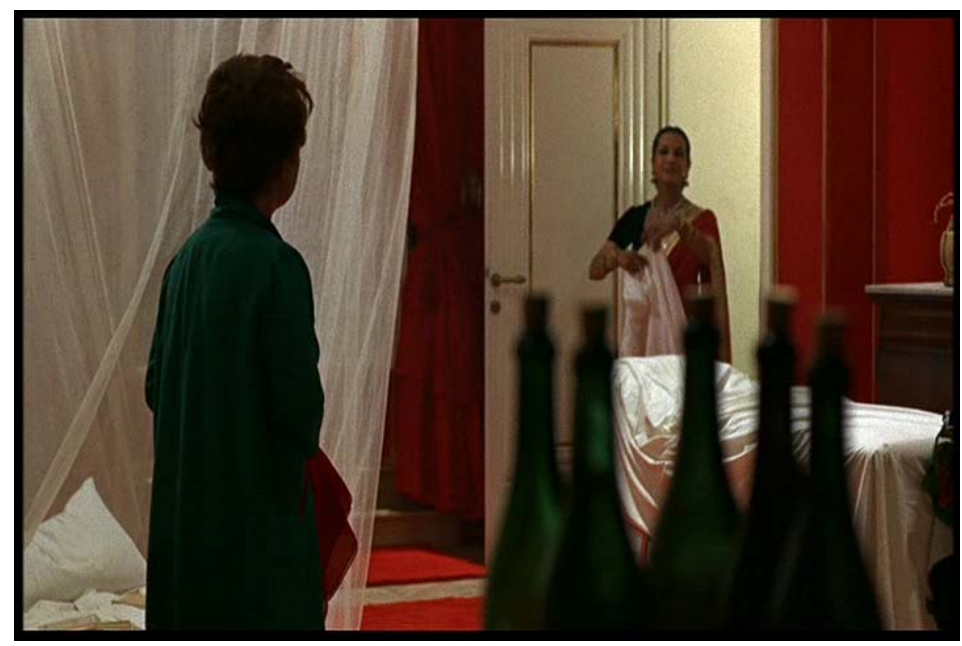

Imagem 69 Quarto do guru Brishma

O contraste de verde e vermelho, recorrente nesta seqüência, permanece no quarto em que ela conversa em particular com o guru, o que talvez possa significar que tudo nesta situação a leva a um estado de quase loucura. Todo o quarto é vermelho, há algumas garrafas de vidro verdes, cuja cor se torna mais acesa quando vista contra a luz, e apenas as portas, cortinas, lençóis e algumas rendas no sofá são brancas, o que permite que o vermelho continue exercendo seu efeito vibrante e marca mais uma vez o conflito de Julieta entre a mansidão e a paixão. Marca também um caráter dúbio da 
mensagem do guru para Julieta - a mensagem oscila entre os valores espirituais, etéreos (branco) e os carnais (vermelho).

As cortinas brancas são usadas para envolver o personagem do guru com um caráter imaculado, santificado e de fragilidade, que o branco pode conferir.

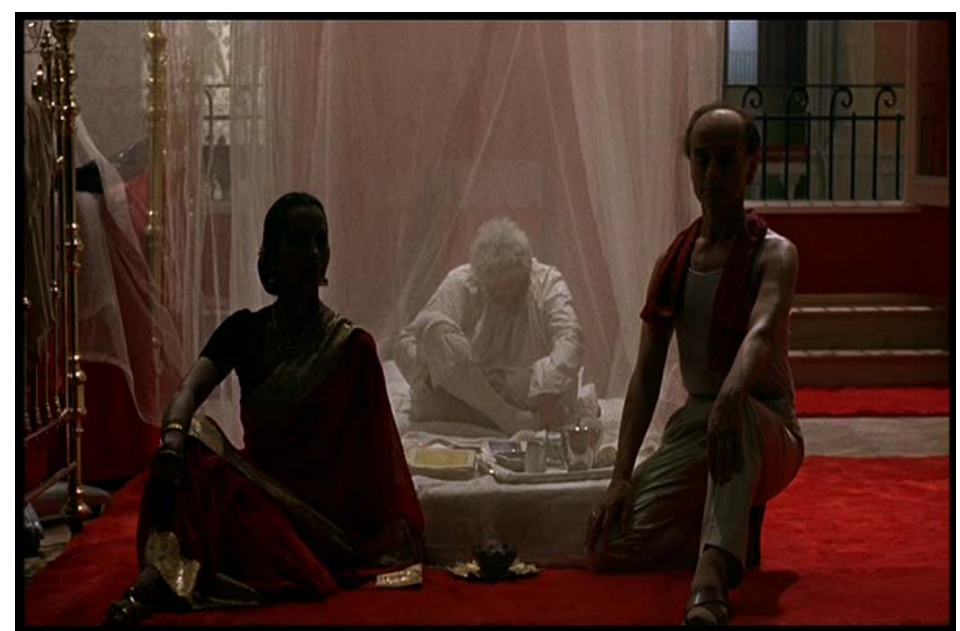

Imagem 70 Quarto do guru: Brishma em sua cama, ao centro, e seus auxiliares a frente

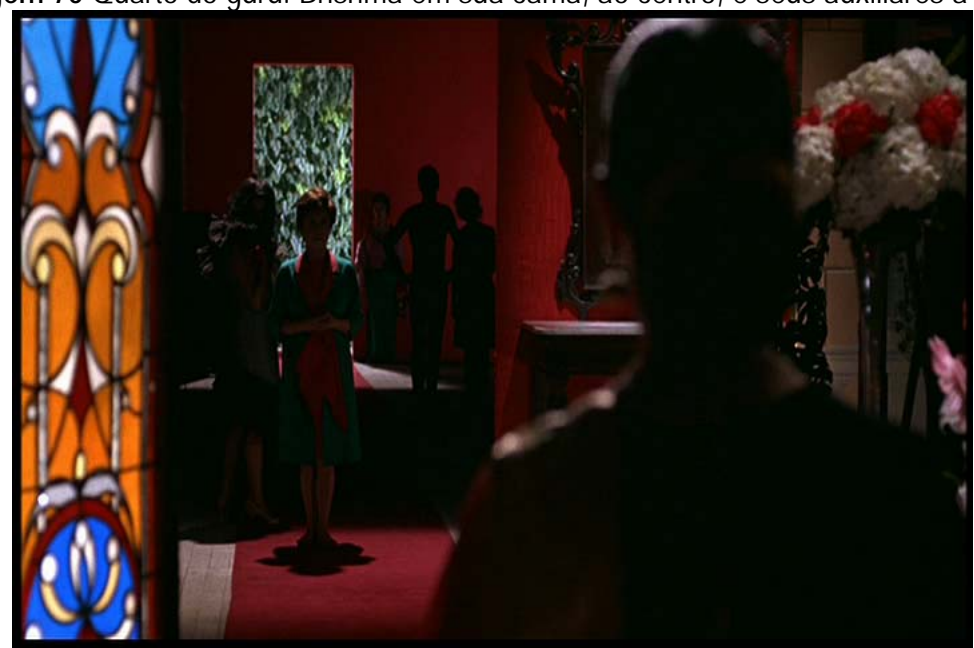

Imagem 71 Ante-sala do quarto do guru Brishma, quando Julieta está indo embora

$\mathrm{Na}$ ante-sala, quando Julieta sai do quarto do guru, percebe-se três contrastes fortes: vermelho / verde, dando continuidade à atmosfera do quarto; azul / amarelo-alaranjado no vitral à esquerda; e claro / escuro, claro no espaço externo / escuro no interno. Os contrastes reforçam a atmosfera de mistério vibrante que emana do lugar e reforçam também a mensagem do guru transmitida neste momento por sua auxiliar - de que algo muito especial lhe aconteceria ainda naquela noite e que provaria de uma bebida chamada "sangria". 


\section{Lembrança do Avô:}

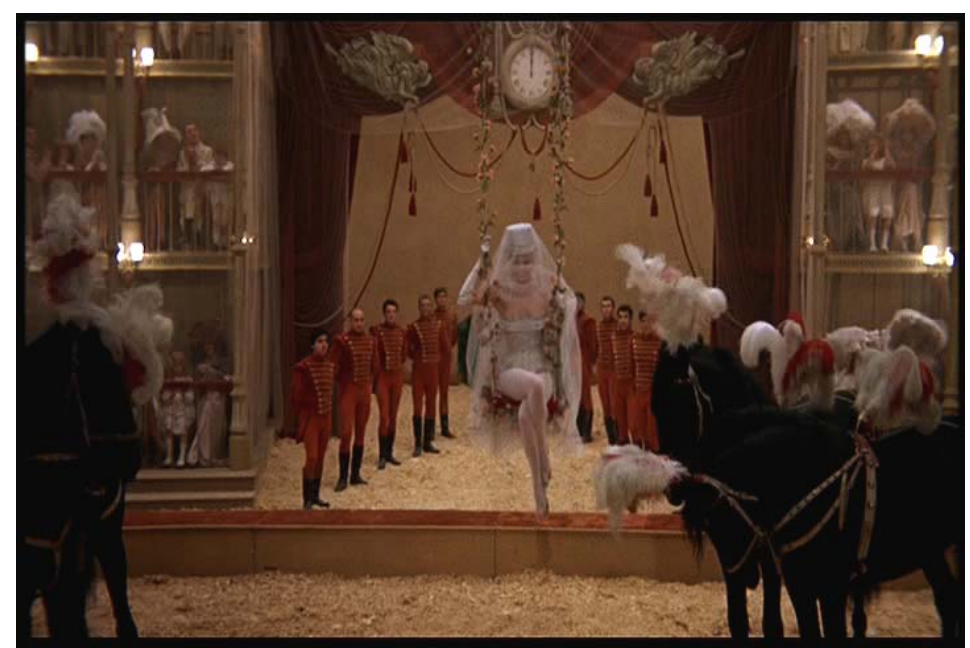

Imagem 72 Bailarina do circo - Fanny - em seu número de balanço

As cenas do Circo são todas sempre quentes e fazem parte das lembranças de Julieta (lembranças do circo, do avô e da bailarina com quem ele fugiu). As cores usadas são vermelhos vivos e tons de amarelo pálido, da serragem usada pela trupe, às instalações verticais onde o público está instalado.

O único elemento que se destaca deste padrão quente é a bailarina, que se veste de branco e que em alguns momentos é iluminada tão fortemente que sua brancura se torna um pouco lilás, contrastando muito com os amarelos e tons quentes adjacentes. O branco em sua figura a torna espectral, inalcançável e leve. Características que combinam tanto com o personagem que todos os outros elementos associados a ela são de leveza: a dança, o balanço, o avião no qual foge com o avô de Julieta, a fisionomia sempre sorridente e divertida. A bailarina, não por acaso, tem as mesmas feições que Suzy, a vizinha, sintonizando as duas personagens na mesma chave da liberdade em relação às regras sociais e ao amor. 


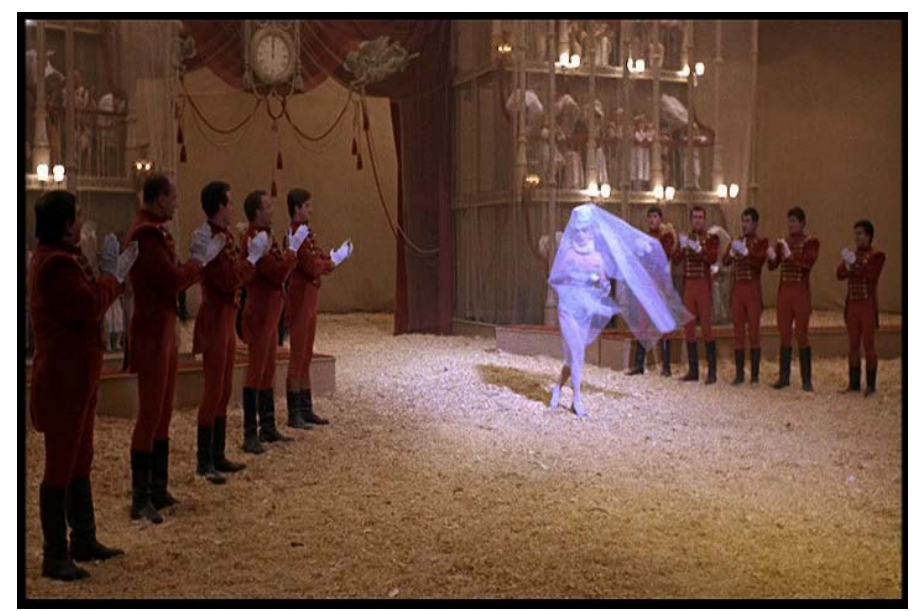

Imagem 73 Bailarina do circo - Fanny
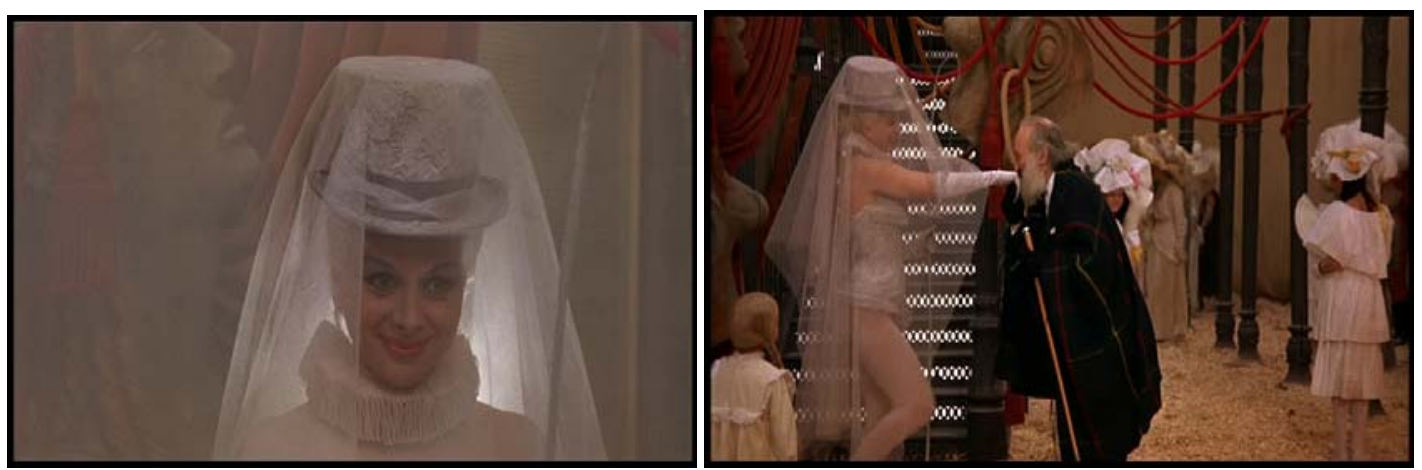

Imagem 74 Bailarina do circo, Fanny.

Imagem 75 Da esquerda para direita: Julieta-criança, Fanny, avô de Julieta e suas duas irmãs ao fundo

Já a mãe de Julieta, como se pode perceber ao longo do filme, mesmo quando usa cores claras e delicadas, é sempre opulenta e ostensiva, devido às formas exageradamente grandes e rebuscadas de seu figurino e de sua maquiagem. Usa sempre cores misturadas, diferentemente de Julieta que parece usar mais cores puras.

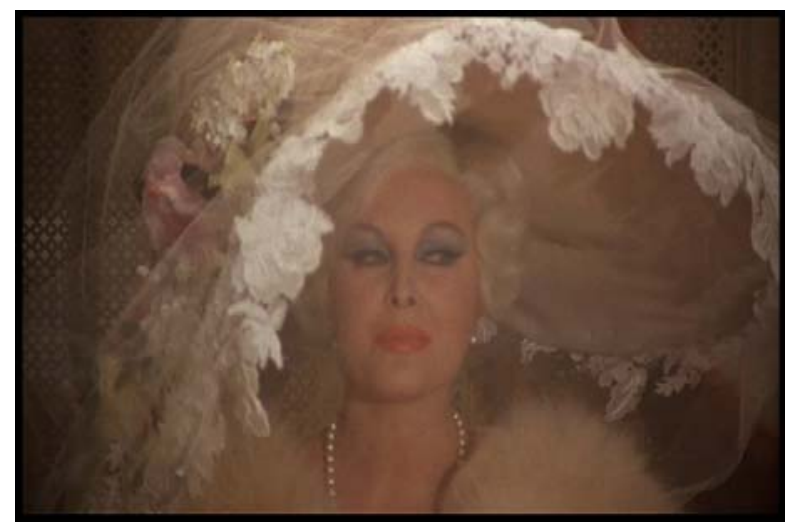

Imagem 63 - Mãe de Julieta

\section{Encontro com José:}

Nesta cena, Julieta está voltando do encontro com o guru, o qual a havia alertado para o fato de que algo de especial the aconteceria ainda naquela 
noite. Assim, tão logo abre o portão, depara-se com um homem desconhecido em seu jardim. É José, um amigo de Giorgio. A primeira visão que temos dele é de fato misteriosa: há uma névoa sobre o gramado e só aos poucos seu rosto se revela, saindo e entrando em pontos de sombra. Contra um fundo escuro, a massa verde da metade esquerda do quadro contrasta com as flores cor de laranja próximas ao personagem.

José conta que cultivava rosas raras num jardim em Córdoba, que é toureiro e que também cria touros, gosta de música, toca violão, entende de diversas formas de arte. José lhe apresenta uma nova dimensão, a da poesia.

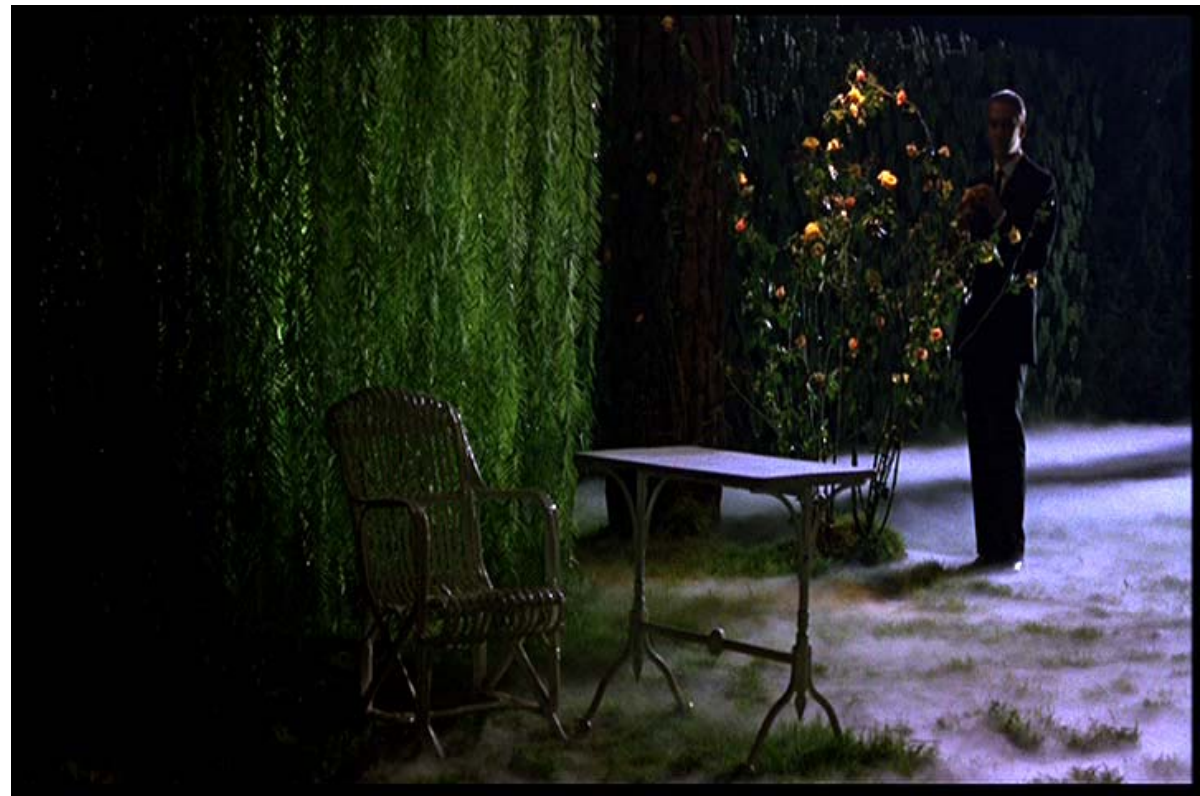

Imagem 77 José no jardim de Julieta

Este personagem representa para Julieta um novo modelo de masculino - sofisticado, capaz de cultivar tanto rosas raras como o amor, a rosa mais rara enquanto metáfora. Como toureiro, José é viril, e não apenas mata touros como os cria; não apenas os fere com sua espada (elemento fálico) como os alimenta. Torna-se muito mais especial, fazendo-os "renascer" em vitalidade, como numa relação sexual.

Por outro lado, no momento em que José demonstra sua habilidade de toureiro, revelando o segredo abstrato de derrotar uma fera, é como se quisesse instigá-la a enfrentar seus monstros com sua própria força e beleza interior. Nesta demonstração, é Giorgio quem faz o papel do animal, revelando seu caráter bruto e insensível. 


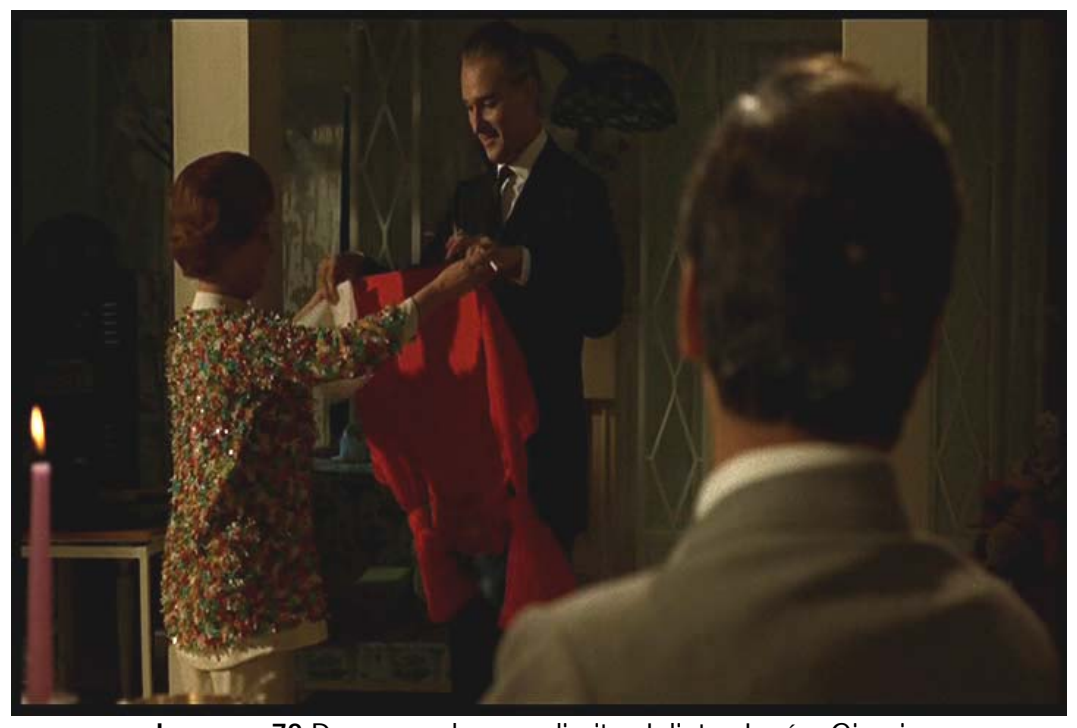

Imagem 78 Da esquerda para direita, Julieta, José e Giorgio

É José também quem prepara para Julieta a "sangria", uma bebida vermelha, que provoca o esquecimento, que mata a sede, mesmo a que jamais se confessa. O que Julieta precisava esquecer? Superar os traumas vividos e matar sua sede de amar e ser amada como de fato gostaria. Tal bebida possui esta cor pois almeja-se aqui conferir paixão, vida, força, coragem a quem bebêla, como se bebesse as próprias características do vermelho neste contexto. Associada ao personagem José, a sangria pode lembrar o sangue do touro e bebê-lo pode soar como um ritual de somar forças. Além do fato que na história da medicina, um processo também chamado "sangria" ter sido um recurso usado para curar pessoas.

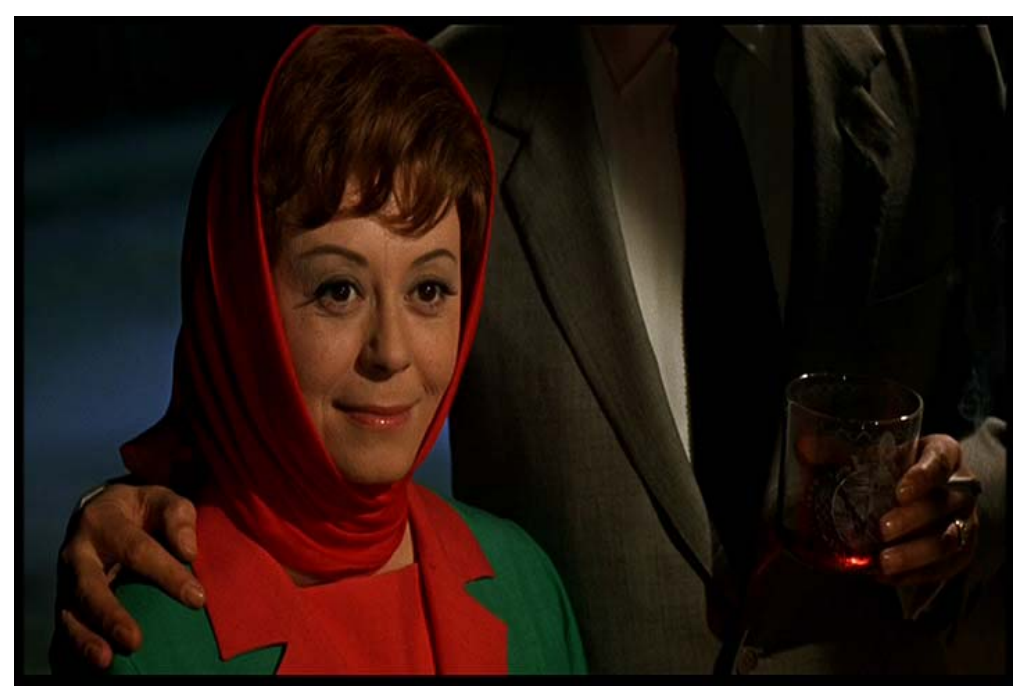

Imagem 79 Julieta olha para José

José é para Julieta quase como o Louco é para Gelsomina, em La Strada (filme que abordamos anteriormente). Ambos simbolizam os mesmos 
elementos: leveza, habilidade, música e poesia. Assim como o Louco, ele também revela uma nova possibilidade, alerta que uma simples decisão súbita pode mudar todo o destino, como o dele parecia haver sido mudado, já que não queria ir à Itália naquele dia, mas agora estava ali e estava feliz.

É evidente que Julieta encanta-se por José. Poderia encontrar nele o par perfeito para seu amor intenso, delicado, mas não se permite - como Gelsomina - procura sempre estar ao lado do marido para não se deixar levar por tais encantos.

\section{Julieta vai ao detetive:}

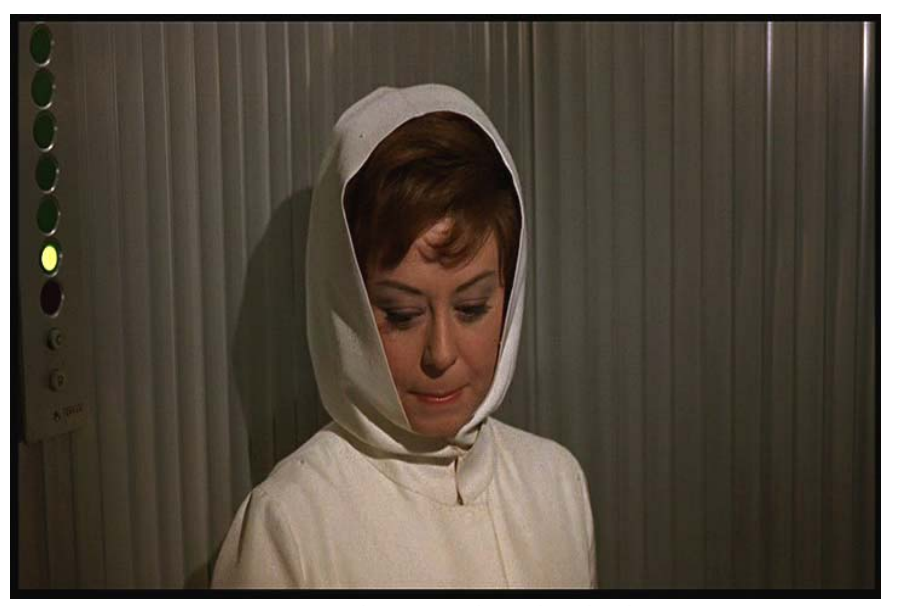

Imagem 80 Julieta no elevador do detetive

Nesta cena, novamente o mesmo silêncio gerador de suspense criado pelo branco. No elevador, as cores são de um cinza frio, que não ajudam a aquecer o tom bege/branco (pouco quente) que envolve completamente o personagem.

A frieza e/ou neutralidade também pode ser notada no escritório, em tons de amarelo claro acinzentado, marrom e cinza. No quadro abaixo vê-se o fotógrafo sentado a frente de um mural que parece ser um mapa com partes seccionadas que facilitem as investigações. Essa sensação de seccionar para analisar, como fazer uma autópsia, é neutra e muito técnica, podemos apreendê-la também por essa imagem. 


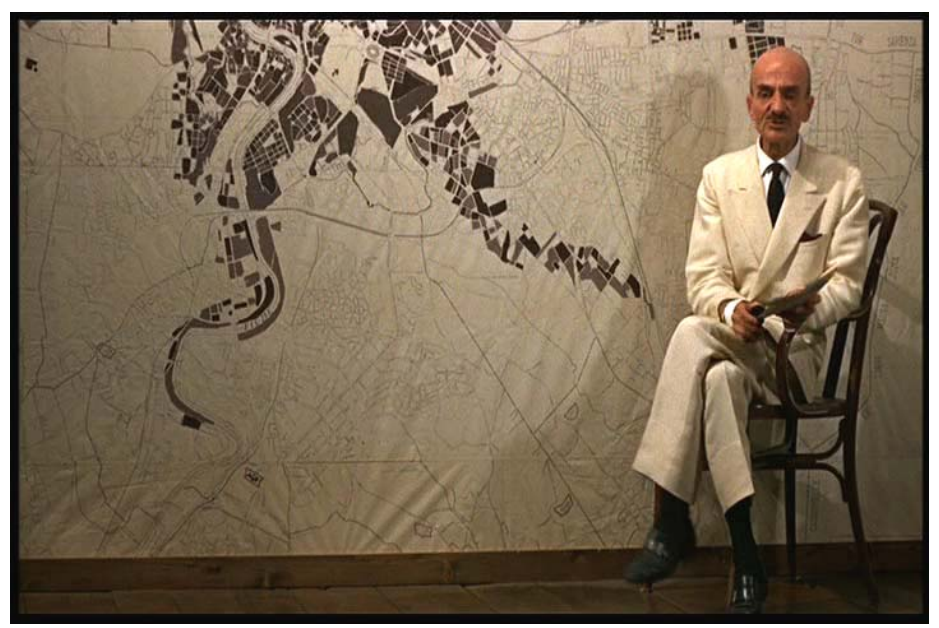

Imagem 81 Fotógrafo-detetive

Após sair do escritório de investigação, Julieta volta para casa, mas lá encontra José, o sofisticado e interessante amigo de seu marido. Ele toca violão no jardim, e ela então decide continuar caminhando para evitar o encontro.

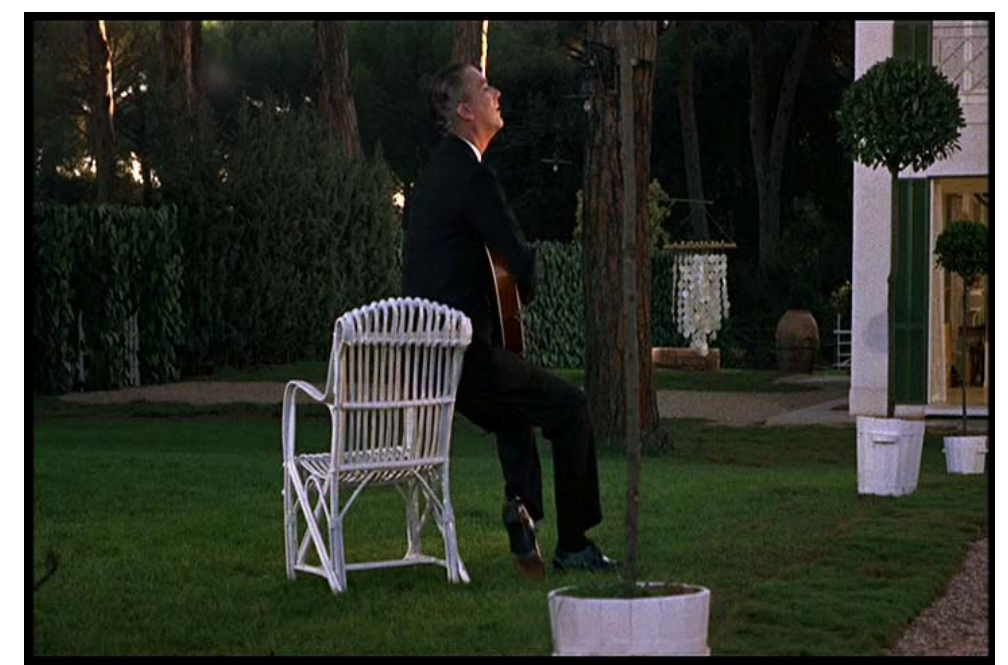

Imagem 82 José toca violão no jardim de Julieta

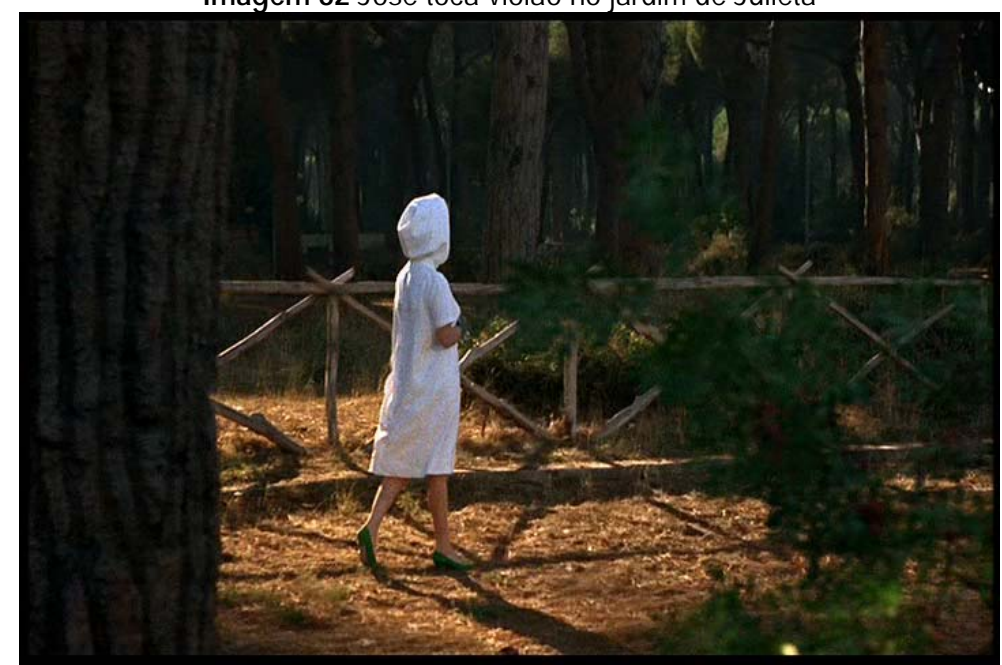

Imagem 83 Julieta caminha em direção ao bosque para evitar encontro com José 
Comparando estes dois últimos quadros, notamos a presença da cor verde e torno das figuras de Julieta e de José. A ligação com os verdes podemos notar já quando ele se apresenta, contando que cultivara um jardim de "rosas áureas" em Córdoba e reconhecendo o amor dedicado ao jardim por Julieta, que está o tempo todo cercada de plantas e árvores.

Estar sempre cercado pela cor verde evidencia o gosto pelo equilíbrio, uma das características atribuídas a esta $\operatorname{cor}^{26}$ e encontradas nos personagens de Julieta e de José.

Ao mesmo tempo, lembrando de seqüências anteriores, pode-se apontar uma ligação destes dois personagens também com a cor vermelha: Julieta associa-se ao vermelho por sua paixão contida (prestes a romper seus próprios limites), sua inquietação; e José, que é um toureiro, está associado à cor vermelha no que ela representa de coragem e também de paixão.

\section{Lembrança do Teatro de Escola:}

O sacrifício permeia fortemente todos os acontecimentos presentes e passados da vida de Julieta. Uma das lembranças mais presentes é de um episódio de sua infância, quando representou Joana D’Arc no teatro da escola. Desde o ocorrido, este arquétipo de mártir parece ter-se cristalizado em sua personalidade e dominar suas atitudes.

Como a Joana D’Arc histórica, Julieta também ouvia vozes e também não seria compreendida por isso. Joana D’Arc morreu por não se subjugar à Igreja, por não aceitar como verdadeiro o julgamento que faziam dela, numa idéia de salvação da alma sobrepondo-se à salvação do corpo (supervalorização da alma em relação ao corpo: espírito x matéria). Só mais tarde é que a Igreja passou a vê-la como santa, mas deixando deturpada a imagem deste personagem histórico, como se houvesse sido queimada para a purificação de seus pecados e não que tivesse aceitado a morte para não renegar suas idéias próprias.

Se lembrarmos o que houve na história real, Joana D’Arc era uma jovem visionária comandando todo um exército numa série de batalhas em nome da

${ }^{26} \mathrm{O}$ verde, como resultante da mistura entre amarelo e azul, apresenta suas forças internas anuladas, um caráter estático, nem quente, nem frio, em equilíbrio, lembrando que as forças internas de suas cores originárias são: do amarelo, para fora (excêntrica) e do azul, para dentro (concêntrica). 
Igreja. Isto certamente também não havia de agradar os mandos do clero, onde todos os grandes representantes são homens, até hoje, e às mulheres só são delegados cargos mais baixos e simples, sempre subordinados aos dos homens. Fellini chega mesmo a afirmar que neste filme gostaria de falar sobre necessidade da mulher tornar-se independente, descobrir sua realidade e emancipar-se sem que este seja um processo imitativo, mas um processo sincero e necessário (FELLINI, 2004, p. 136 e 137).

A visão que temos de Julieta tão pequenininha subindo numa "grelha" em chamas é tão horrível que não importa que sejam chamas artificiais (como não importa que o mar cenográfico de Amarcord seja de plástico). O que fica, e choca, é a idéia do sacrifício da pureza, da sinceridade, da espontaneidade, de tudo o que é vivo na figura daquela menina de tranças. É sacrificar isso tudo enquanto se é pequeno e não se pode defender-se sozinho.

Uma relação possível que se pode fazer entre esta lembrança de infância e a vida atual de Julieta é que ela continua sacrificando suas oportunidades de ter de fato uma vida plena de satisfação, de crescer enquanto indivíduo. O próprio casamento morno vivido por ela é um excelente exemplo disso. Julieta fica a mercê do marido, da uma mudança de postura que nunca acontece, de um gesto amoroso que nunca é por inteiro. Enquanto isso não acontece, ela não se liberta e não segue adiante, não descobre o mundo, nem a si mesma. Permanece na "infância" desde conhecimento, se submetendo a este sacrifício.

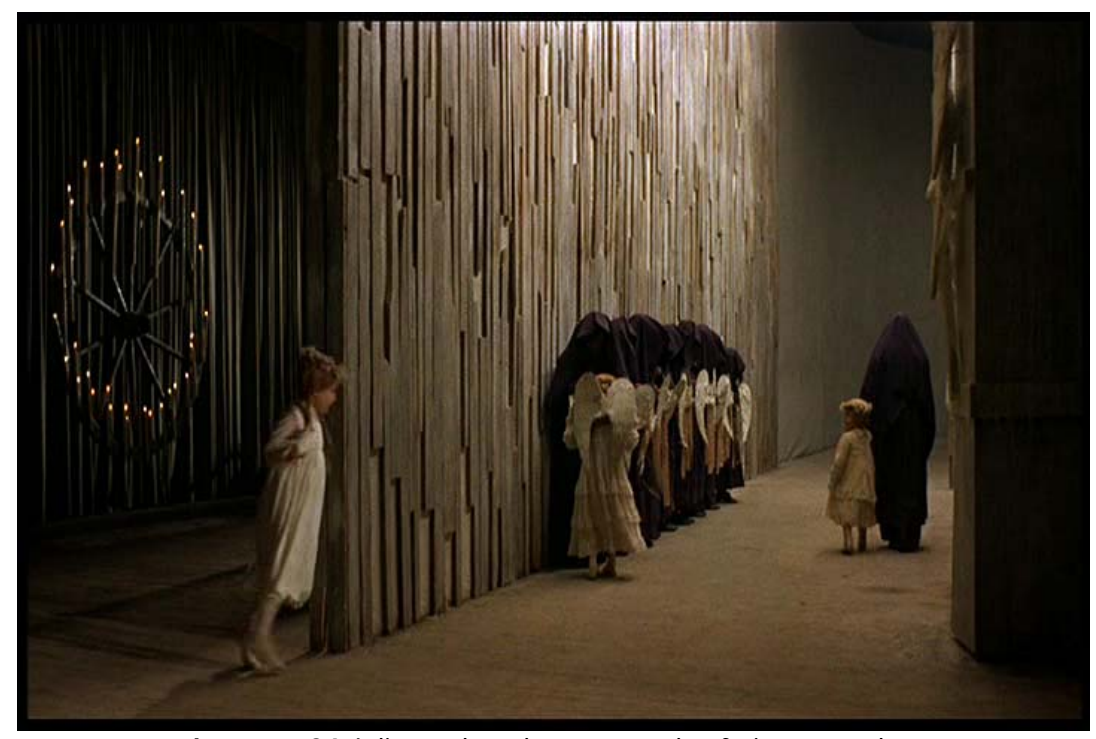

Imagem 84 Julieta é levada por uma das freiras ao palco 
As lembranças do Teatro da Escola são sombrias e isso se traduz pelo uso da cor roxa (que é uma cor fúnebre para a Igreja) num tom bastante escuro, quase preto. Em torno destes vultos roxos, cujos rostos não podemos ver (eles se movimentam em cena com um gestual muito parecido, quase idêntico, movem-se como uma massa de identidade uniforme) a cor é um bege de tons mais claros e mais escuros. Esse bege pode ser entendido como um tom de amarelo bem pálido, cor complementar do roxo, criando um contraste interessante.

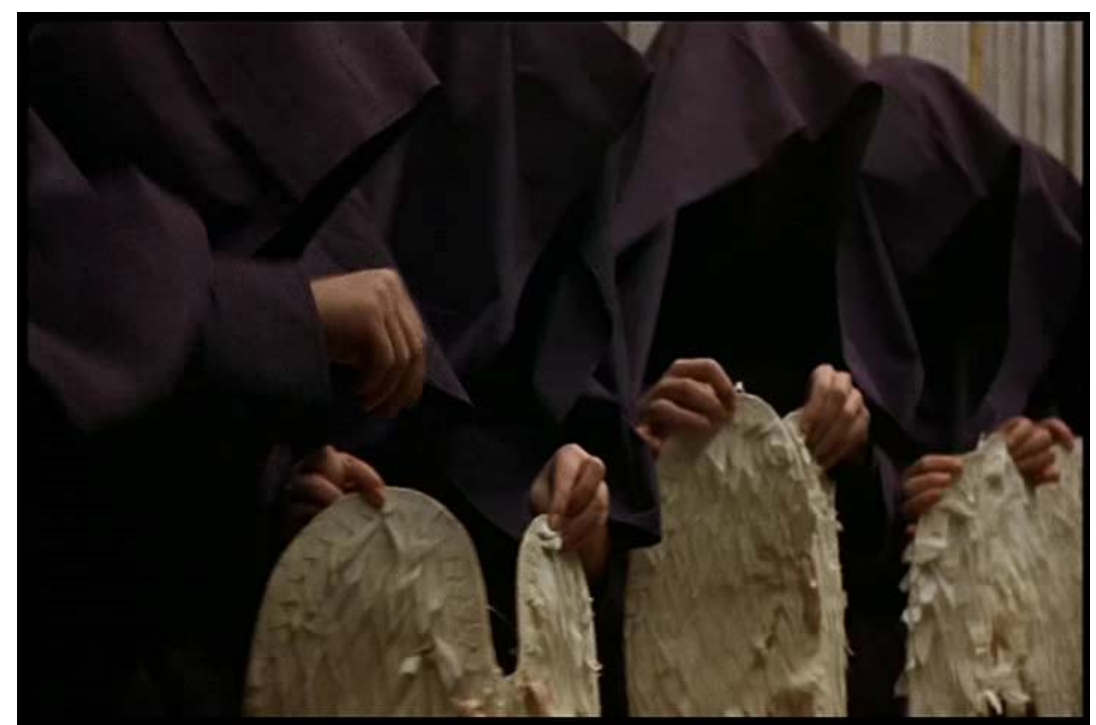

Imagem 85 Freiras em fila vestem as outras meninas com asas de anjo

A imagem de pureza das crianças que são vestidas com asas de anjo, uma a uma, pelas freiras, também é muito forte. As crianças vestem-se de branco, mas têm um fino véu arroxeado cobrindo toda a cabeça. Isto sugere que suas visões estão cobertas, atrapalhadas pelo ponto de vista da Igreja (e roxo passa a ser sua cor representante), e também dá certo aspecto de morte ao tom da pele, a vida que lhes é tomada pelo dogmatismo cerceante da Igreja. Pode-se lembrar que o roxo, que podemos identificar como sendo da Igreja, também é muito usado pelo personagem da mãe, outra figura repressora, opressora nesta história. 


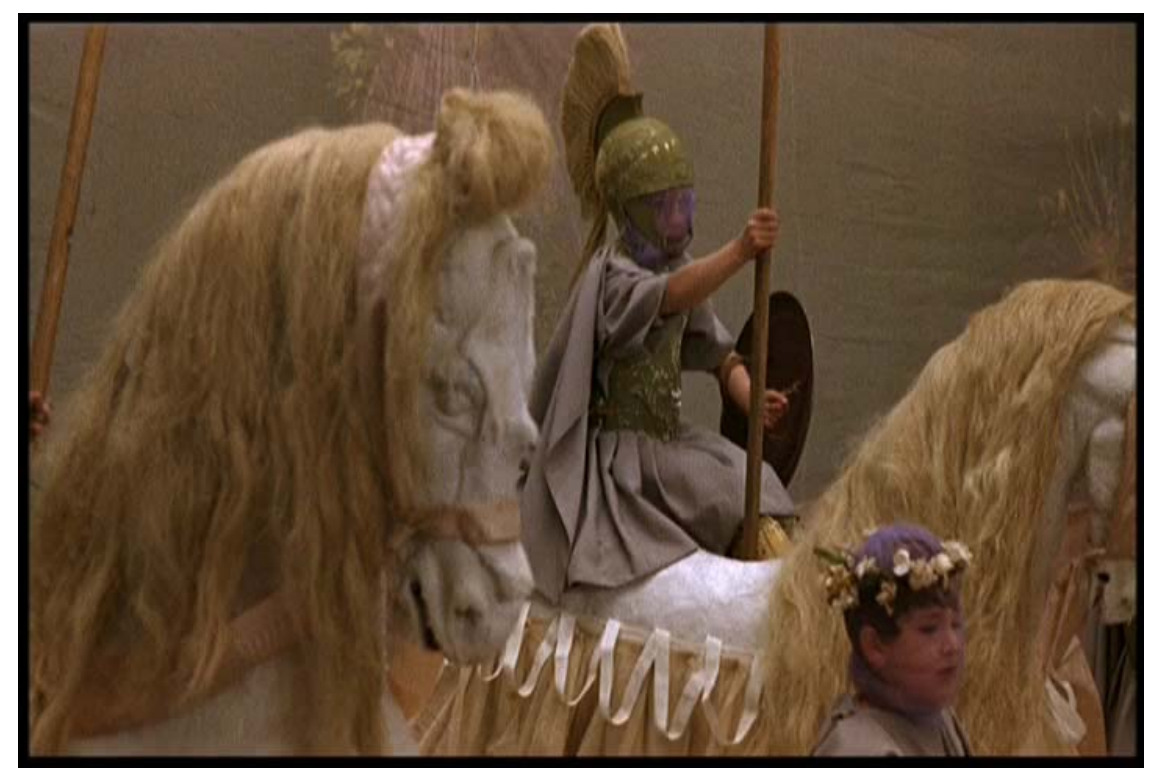

Imagem 86 Meninos representam soldados que prendem Joana D'arc para ser queimada na fogueira

Apenas o avô se importa em salvá-la da fogueira no teatro, deplorando o que querem que aquilo signifique, para escândalo de $\operatorname{todos}^{27}$. Não coincidentemente, é ele quem aparece num dos últimos momentos do filme levando Julieta para fora de sua casa.

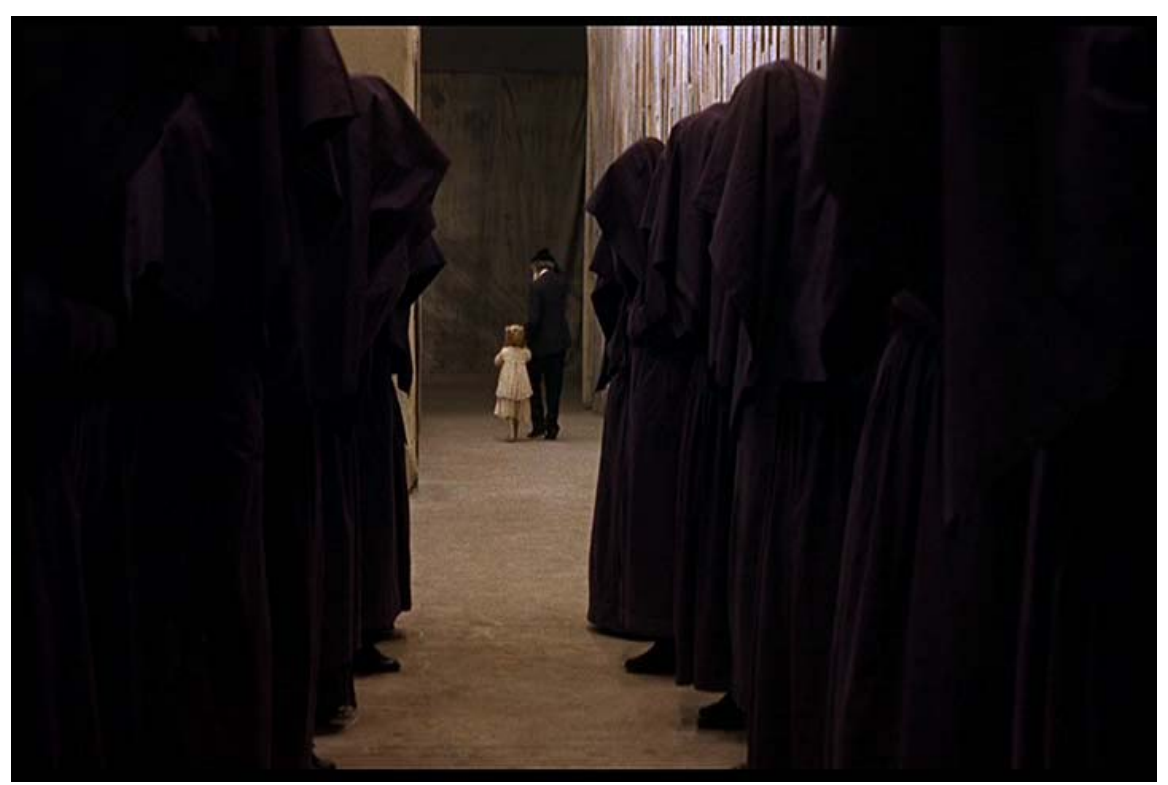

Imagem 87 Freiras em fila com Julieta e seu avô ao fundo, indo embora

No fotograma acima, vemos duas fileiras de freiras que, em perspectiva, apontam para onde estão indo, Julieta e o avô, no centro. São duas massas praticamente uniformes de roxo, cor fria, tendendo ao preto, portanto também

27 O avô parece ser um homem impulsivo que demonstra estar mais preocupado com as pessoas do que com regrais morais e sociais. Ele é professor na escola onde acontece a apresentação e é ameaçado de demissão pelo reitor no momento em que interrompe o espetáculo. Por ser avô, pode se interpretar que ele é "pai duas vezes" de Julieta. É a referência masculina para ela, aquele que protege, indica o caminho certo, lhe dá espaço. 
bastante escura, produzindo um resultado assustador. Perecem vultos malévolos, sempre a observar, perseguir.

O tom mais amarelo de todos encontra-se no cabelo da menina Julieta e das outras meninas da peça. E o tom mais vibrante de todos sem dúvida reservou-se para a fogueira de Joana D’Arc: dela vem um vermelho flamejante que reforça a brutalidade do ato de ser queimado - e se olharmos por outro lado, reforça também a paixão de quem não abdica de seus princípios.

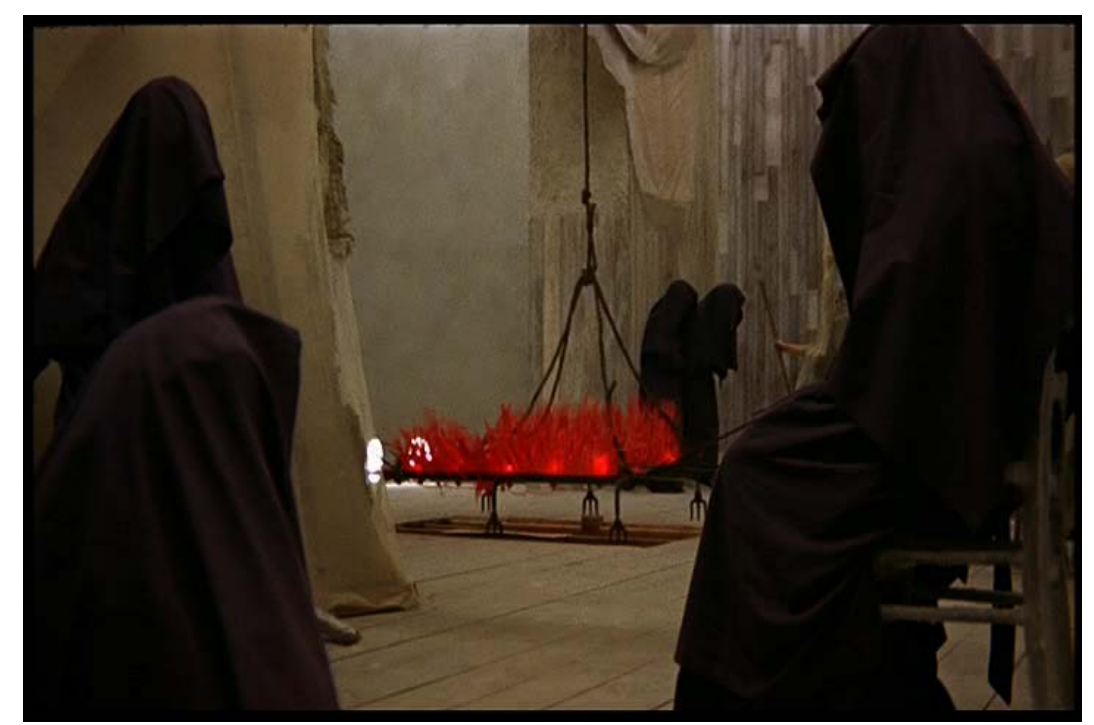

Imagem 88 Freiras nas coxias e fogueira de Joana D'Arc ao centro do palco

No momento em que Julieta está se recordando do episódio, imagina-se novamente na fogueira em que estivera quando criança. Sua feição serena de beatitude nos faz entender a naturalidade com que enfrenta sacrifícios. $O$ branco de sua roupa é sereno como sua feição, puro, ingênuo. E o vermelho queima com o mesmo ardor passional com que Julieta tende a se sacrificar. 


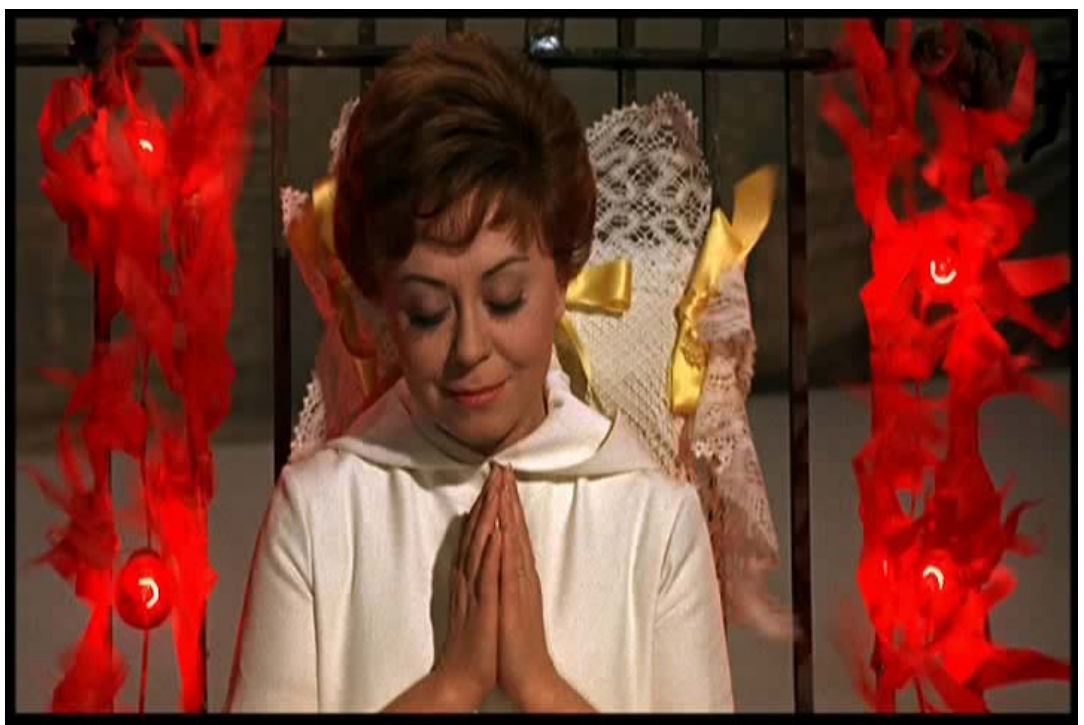

Imagem 88 Julieta adulta se imagina na fogueira - memória e metáfora

O contraste de vermelho e branco aqui evidencia mais uma vez um conflito: ser morto, sacrificado, o que é algo agressivo, brutal, com a serenidade do branco, que se doa a este sacrifício, como se fosse algo bom. A visão de Fellini sobre a Igreja é aqui mais uma vez crítica, afinal, que amor a Deus é esse que em vez de elevar nossa vida, de fazer-nos celebrá-la, nos faz perdê-la?

\section{Visita à casa de Susy:}

O cenário da casa de Susy, parece ser uma velha mansão, aqui sim, com forte inspiração art nouveau. Nela vivem Suzy, sua mãe, sua avó e amigos que ela acolhe.

Julieta, um dia vai visitá-la para devolver-Ihe um gato fujão - animal escolhido provavelmente por carregar certas características de sua dona Susy, o gato liga-se a sensualidade, a aspectos místicos e a um caráter traiçoeiro, e não de fidelidade, o que geralmente atribui-se aos cães. Na imagem anterior pode-se ver a sala de entrada da casa, repleta de cores no cortinado de mosaicos de organza, furta cor, lembrando as asas de uma libélula. No conjunto, ainda que haja um colorido variado, a resultante deste colorido tende bastante ao amarelo, cor deste personagem, indo do amarelo claro aos tons de laranja, nas plumas expostas a luz ao fundo da sala e mesmo nos vermelhos da cortina, que contra a luz se misturam à cor amarela da janela resultando num tom de alaranjado. 


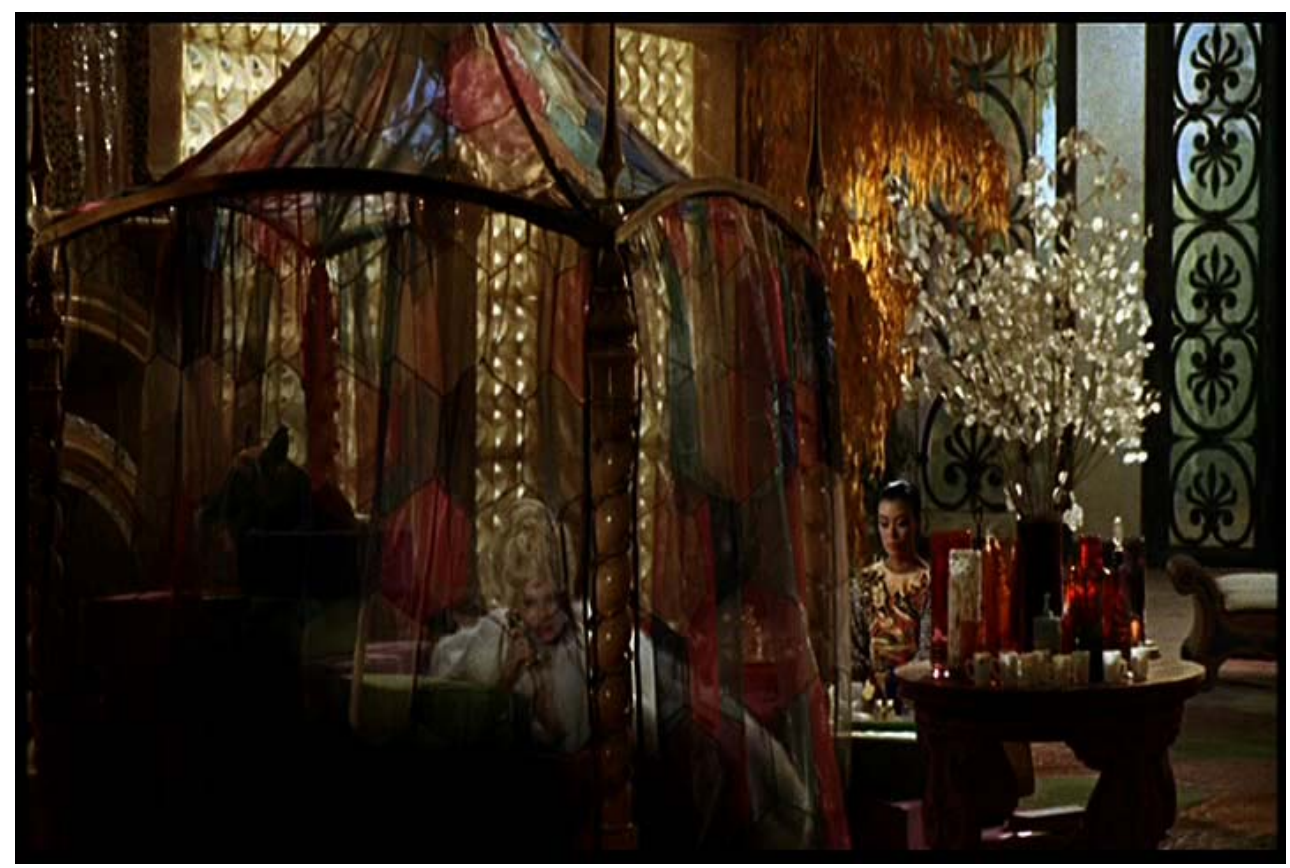

Imagem 89 Sala de Susy

As formas são sinuosas e femininas, bastante orgânicas, nos lembram formas encontradas na natureza. No corrimão, vê-se desenhos que lembram os da asa de uma borboleta, os formatos sextavados da cortinas que podem lembrar os orifícios de uma colméia, se repetem também no piso. As grandes janelas vitrais possuem desenhos de pavões com grandes caudas coloridas. Esta ave, cuja imagem se vê algumas vezes neste cenário, diz algo a respeito de Susy. Como o pavão, Susy impressiona por sua exuberância, pela beleza majestosa que logo se vê.

Como o caráter de Suzy é festivo, alegre, ávido e amoroso, tudo em sua casa segue o mesmo ritmo. As plantas trepadeiras crescem viçosas e desordenadamente, possuem tons quentes do amarelo ao vermelho alaranjado, e algumas folhas verdes, sobem pelas paredes e colunas sem que ninguém as controle - como instintos livres. Este aspecto de algumas folhas parecerem estar na estação do outono, outras na do inverno e outras na do verão ou primavera, representa os diferentes ciclos da vida em harmonia, embrenhados na casa através das três gerações de mulheres - Susy, sua mãe e sua avó. 


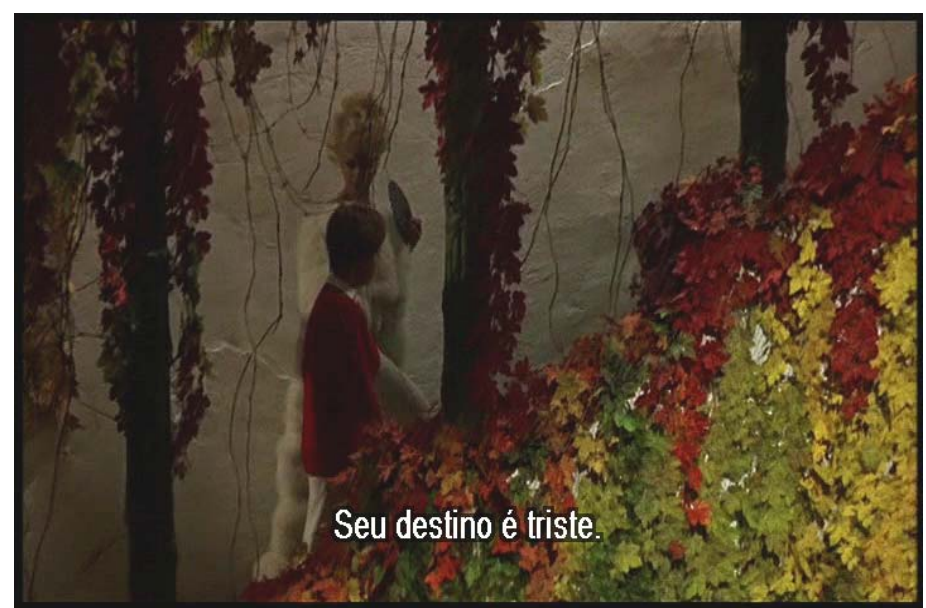

Imagem 90 Susy e Julieta sobem uma escada externa da casa de Susy

Já no quarto de Susy, o amarelo se mostra mais uniforme, pois o quarto é um ambiente mais pessoal, mais individual, e por isso acaba mais impregnado de traços do personagem que os outros ambientes.

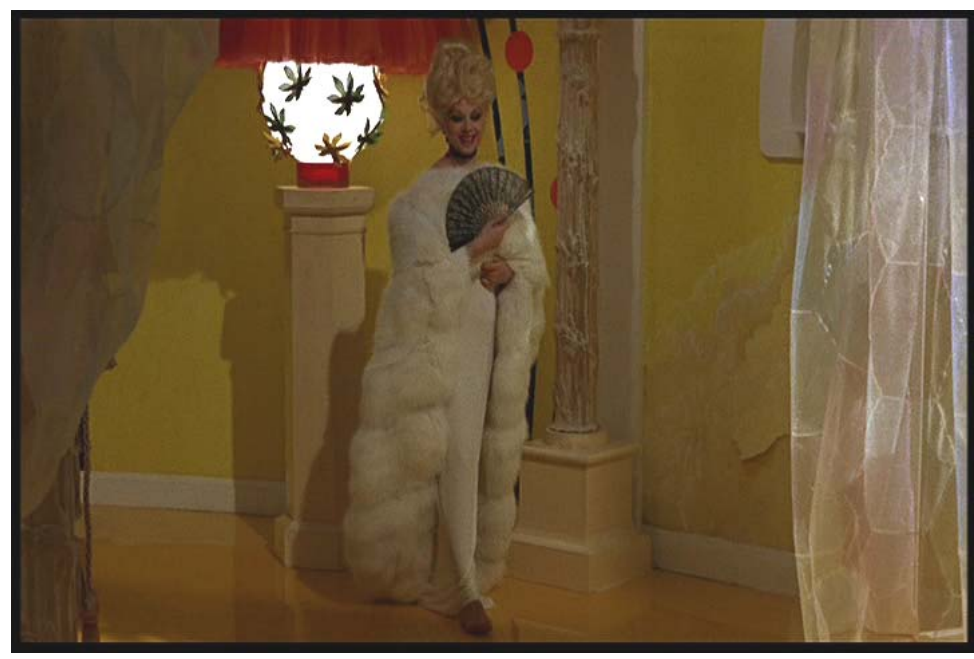

Imagem 91 Quarto de Susy

Sabe-se que no início, o amarelo era a cor do amor legítimo. Mas, sabendo disso, na Grécia e, principalmente em Roma, as cortesãs começaram a se aproveitar deste valor atribuído. A partir de então, tornou-se a cor das prostitutas e do amor libertino, e por isso o cristianismo passou a olhá-lo com preconceito e recriminação àqueles que se associassem a ele (EISENSTEIN, 1990, p. 80).

O amarelo como cor excêntrica, que foge do centro e salta para fora de seus limites, se parece muito com o personagem de Susy que vai em direção a todos os seus desejos e nunca deixa de saciar nenhum. Não poderia ter sido escolhida outra cor para ela como principal. Suas cores, além desta, são cores quentes e ativas. 
O fato de Susy, sua mãe e a avó, pertencerem juntas à mesma casa, não parece casual e todas as três partilham da mesma cor principal, o amarelo. Todas as três não estão presas a nenhum homem e parecem ter um dom especial, como sendo uma linhagem de mulheres magas que produzem feitiços e encantos. A avó de Susy descobre os segredos das pessoas assim que olha para elas. A mãe prepara perfumes secretos com flores e resinas que servem para enlouquecer os homens.

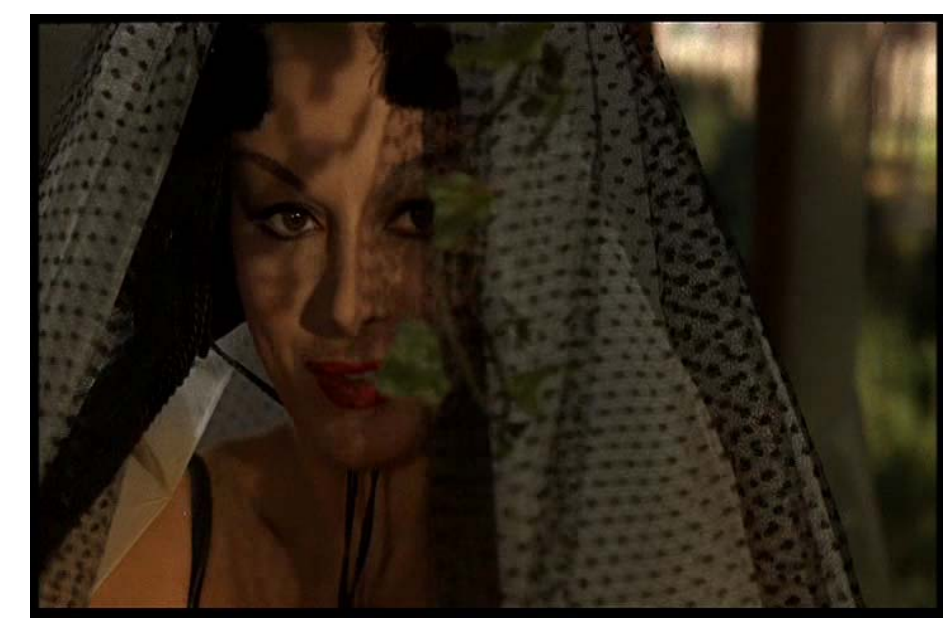

Imagem 92 Plano próximo de Susy com o manto

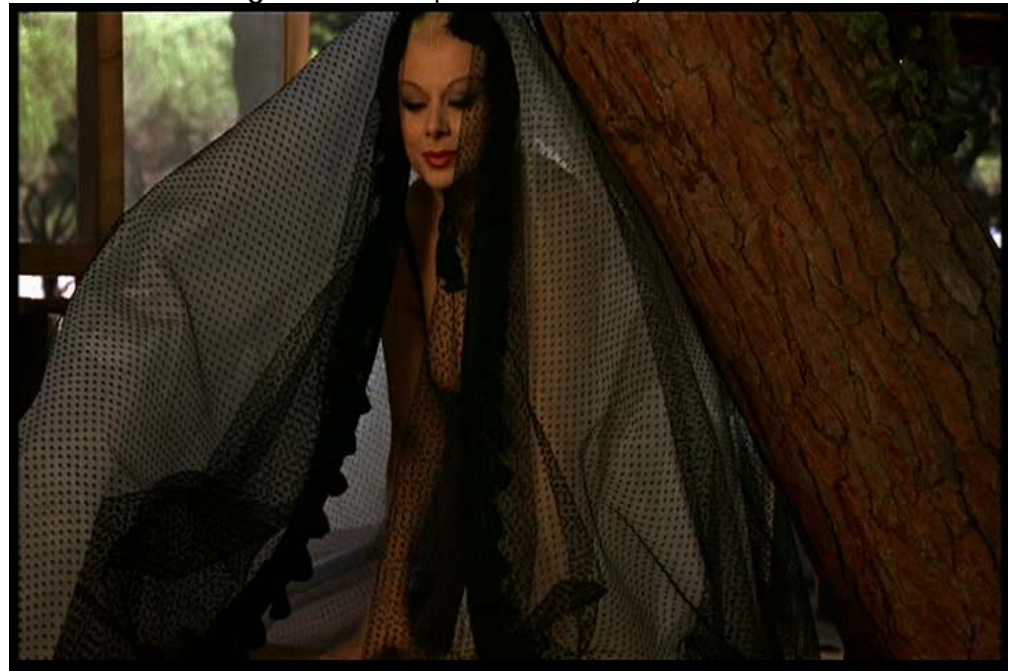

Imagem 93 Susy no alto da árvore em seu esconderijo - sequência do passeio pelo bosque com Julieta

O negro que se observa em seu figurino evoca algo de misterioso. Suzy poderia ser identificada como uma bruxa ou feiticeira, e seu feitiço é amoroso. Os chapéus que usa, por exemplo, nos possibilitam fazer esta identificação, se parecem com os usados pelas bruxas clássicas que conhecemos (de abas largas, comprido e mais estreito na parte de cima), suas capas emendadas com os chapéus, abundantes, dão movimento em torno de seu corpo. $O$ 
caldeirão através do qual ela sobe até o esconderijo, também se parece com um caldeirão de bruxa.

Como disse o guru Brishma a Julieta: "o amor é uma religião", e Susy parece mesmo ser sua sacerdotisa. O manto cinza que usa nesta cena (pela mistura ótica do tecido branco que está por baixo com a renda preta que está por cima) parece-se também com um véu ou um manto sagrado. Reparemos que aqui, Fellini não coloca uma bata de freira numa representação irônica de religião, mas numa representação muito mais próxima do sagrado. Assim, Susy na representação de Fellini não se aproxima de uma meretriz ou uma cafetina, mas de uma sacerdotisa realmente.

\section{Julieta volta ao detetive para ter resposta:}

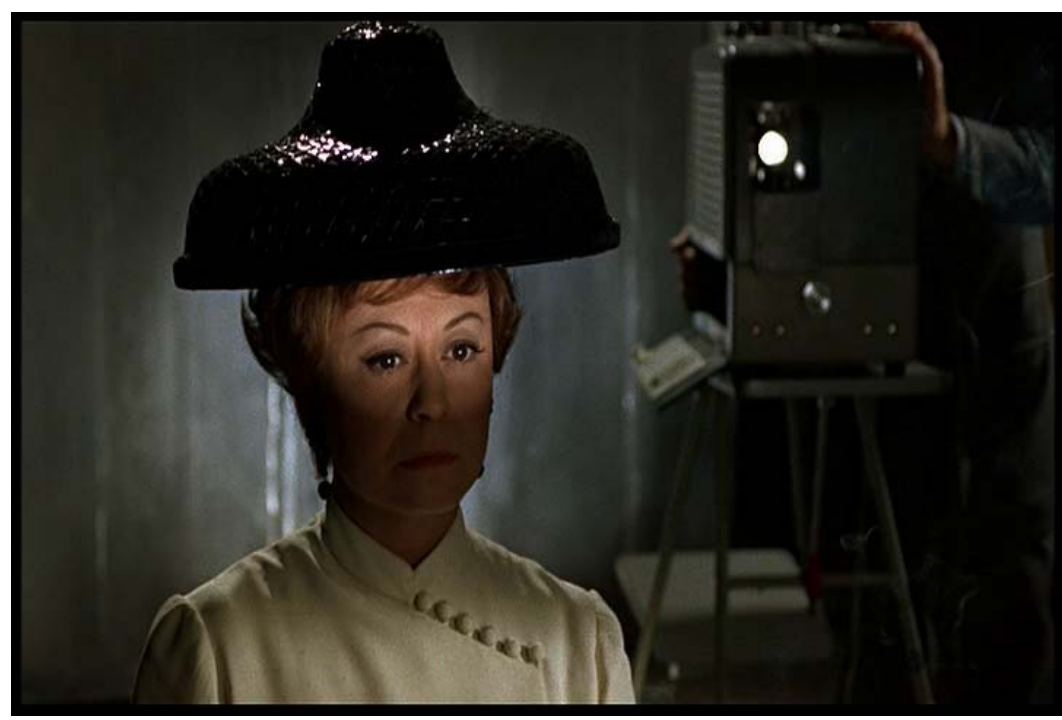

Imagem 94 Julieta assiste o filme da traição de Giorgio feito pelo detetive

É a cena em que Julieta obtém a comprovação da traição do marido. A expressão do personagem é triste e as cores utilizadas também - apenas preto, tons de cinza e um branco levemente amarelado. O chapéu paira como uma nuvem negra sobre a cabeça de Julieta, porém vem clarear seus pensamentos como uma cúpula de abajur, direcionando a luz.

Neste quadro pode-se notar que há um alo de luz incidindo na região da cabeça e na região dos olhos, evidenciando o fato de que ela agora pode enxergar tudo com clareza, ainda que tudo pareça tão escuro ao seu redor. O uso do preto bem próximo da área iluminada faz com que estas duas qualidades sejam evidenciadas: a luz incidente sobre Julieta fica mais marcada, e o escuro do chapéu também. 
Usa nesta segunda visita ao escritório de investigação, outro vestido branco. Parece um vestido chinês, com uma fileira de botões em diagonal na altura do peito, fechado até o pescoço. Desta vez, usa um chapéu preto arredondado, mas com um bico no topo sinalizando diferenciação em seu comportamento, um descolamento do antigo estado de acomodação.

\section{A casa da amante Gabriela:}

A casa da amante Gabriela contrasta muito com a casa de Julieta e, aponta que é bem provável que suas personalidades também contrastem. A cor mais presente é um vermelho desbotado, um pouco amarronzado e escurecido, ao contrário da de Julieta que é verde e branca. A madeira dos móveis, da estrutura da casa, possui um tom escuro e é trabalhada com entalhamento, por desenhos rebuscados. O design dos móveis é pesado e a casa é cheia de objetos. Não há jovialidade, vê-se uma sensualidade velha e decadente, que comprovamos quando ficamos sabendo pelo diálogo da governanta com Julieta que quem escolheu toda a mobília foi Giorgio - o que também comprovaria uma oposição entre o gosto dele e o da esposa, além de um descompasso na relação dos dois.

Sobre Gabriela, só nos é dado a conhecer o nome, Gabriela Olsen, a profissão, modelo, a idade, 24 anos, e a casa, mobiliada por Giorgio, que acabamos de abordar. Do seu figurino podemos ver apenas um traje, que é o que ela usa no filme feito pelo detetive, cuja cena é filmada de um plano distante. Nele a moça aparece com um vestido reto, elegante, na altura dos joelhos, estilo Chanel, sem mangas, possui uma listra branca próxima à gola. Gabriela é jovem, parece ser alta, magra e bonita. O seu acessório mais marcante é um chapéu preto, de abas bastante largas com a beirada branca, muito elegante, que é visto voando na cena filmada pelo detetive e nas mãos da governanta que arruma a mala da moça enquanto Julieta está em sua casa. 


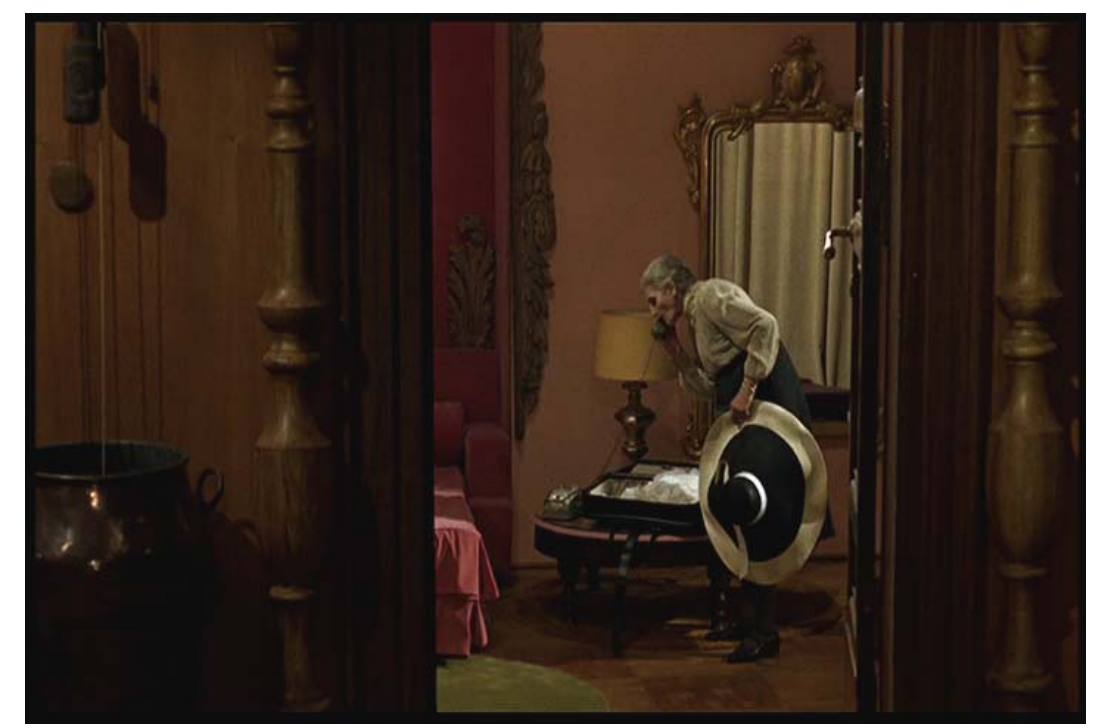

Imagem 95 Governanta segura o chapéu de Gabriela

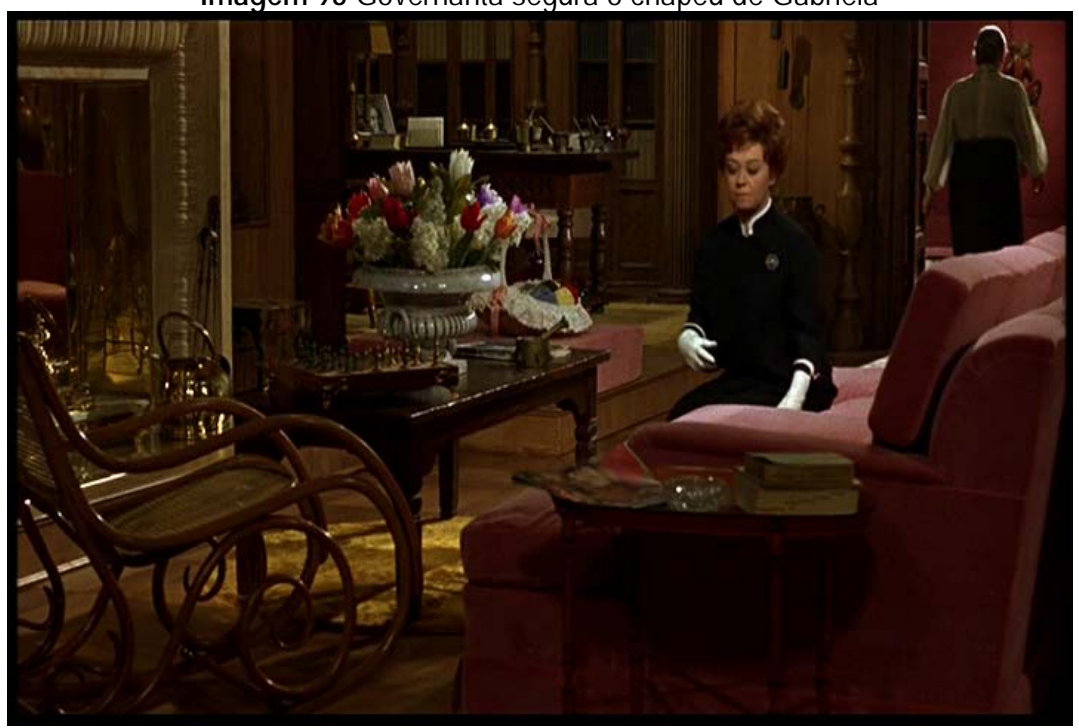

Imagem 96 Julieta em casa de Gabriela

\section{Festa da Casa de Susy:}

A casa de Susy, principalmente em ocasião desta festa temática, é um templo de prazeres e beleza o que fica evidenciado pelo colorido que aguça os sentidos de quem observa. Há até frutas penduradas em uma trepadeira (no alto, à direita do quadro) que sobe pelas colunas do grande salão, aguçando até o paladar. Como o fundo é escuro, as cores parecem mais concentradas e se tornam mais vivas para o nosso olhar, como acontece com o fundo preto nos exercícios de Albers (2009, p. 132 - 136). 


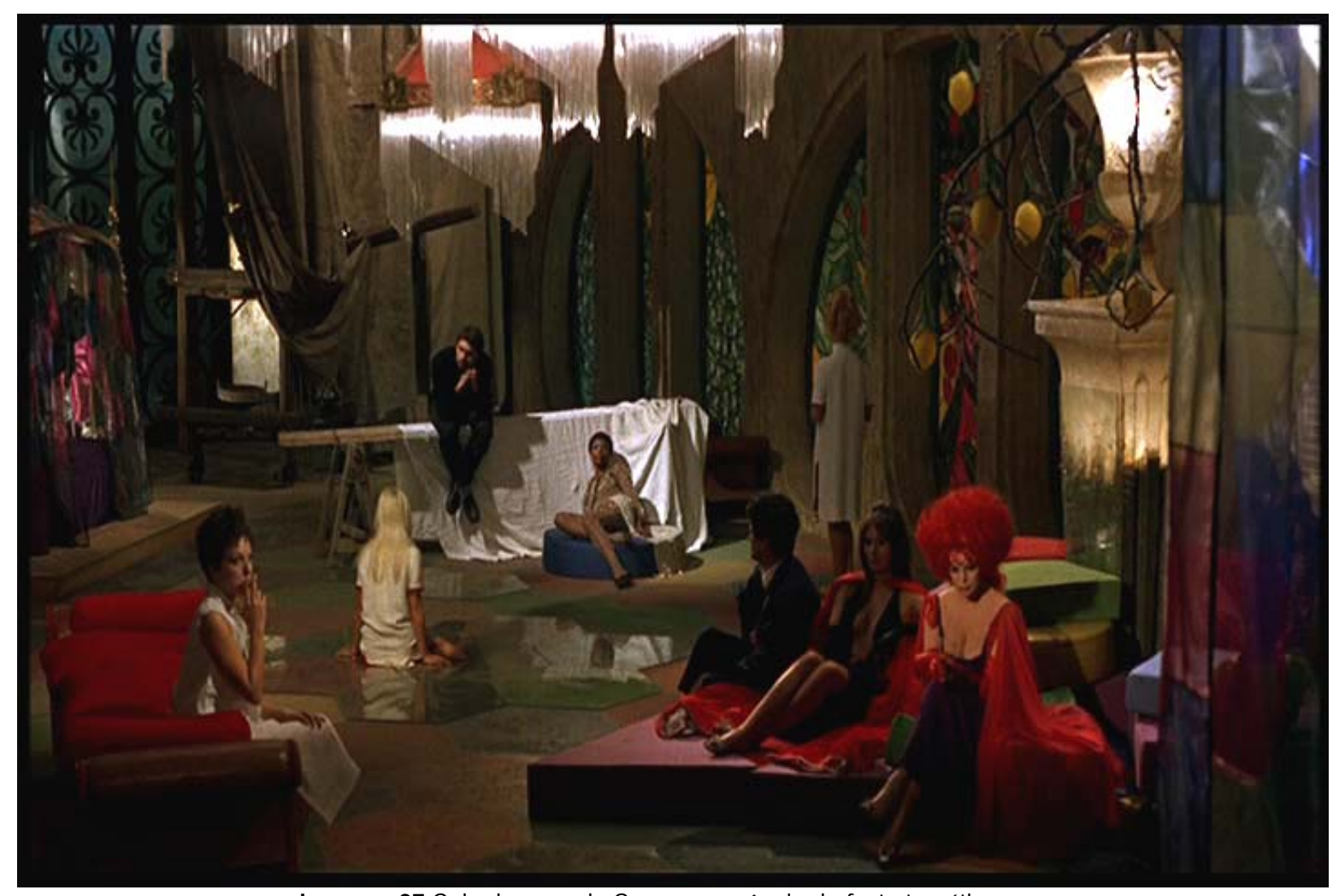

Imagem 97 Sala da casa de Susy - sequência da festa temática

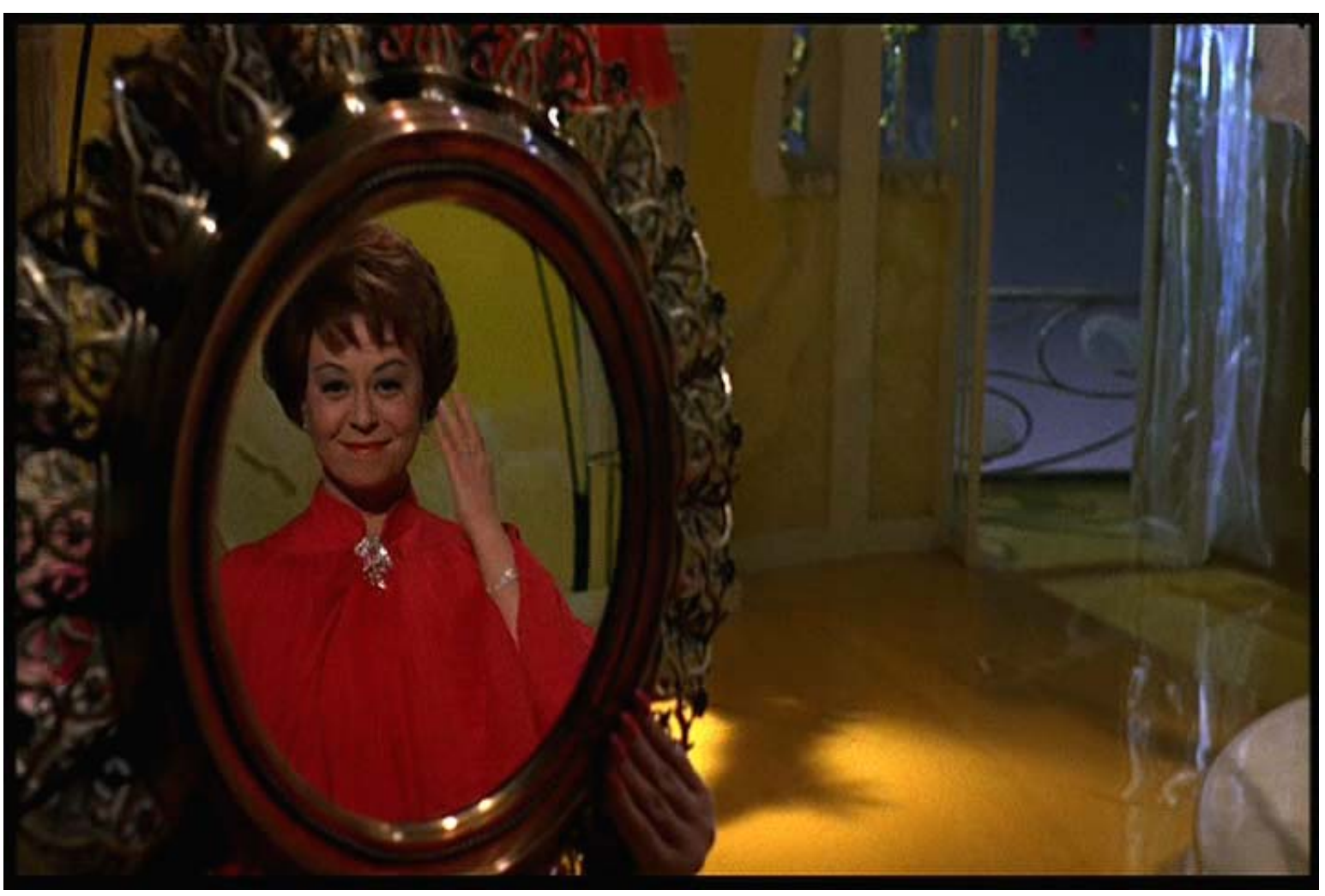

Imagem 98 Julieta no quarto de Susy

Neste fotograma, Julieta se olha no espelho ao adentrar o quarto de Susy para um encontro com um jovem rapaz, os contrastes são vibrantes como 
seu estado de espírito. O azul violetado no canto direito, no alto, contrasta com o amarelo (complementar) no chão, que torna-se ainda mais vibrante quanto mais próximo do espelho, emprestando mais luminosidade à imagem de Julieta.

Sua imagem com o vestido vermelho faz o amarelo da parede atrás dela parecer um pouco esverdeado, puxando para o verde por causa do contraste complementar com o vermelho.

Nesta festa, a intenção de Julieta é se vingar do marido traindo-o também, mas sente-se incapaz de fazê-lo. Ousa por estar completamente de vermelho, mas continua sendo mais elegante que insinuante, e mantém o estilo sem decotes e sem revelar os braços. O vermelho aqui é ao mesmo tempo febril, enraivecido e levemente sedutor.

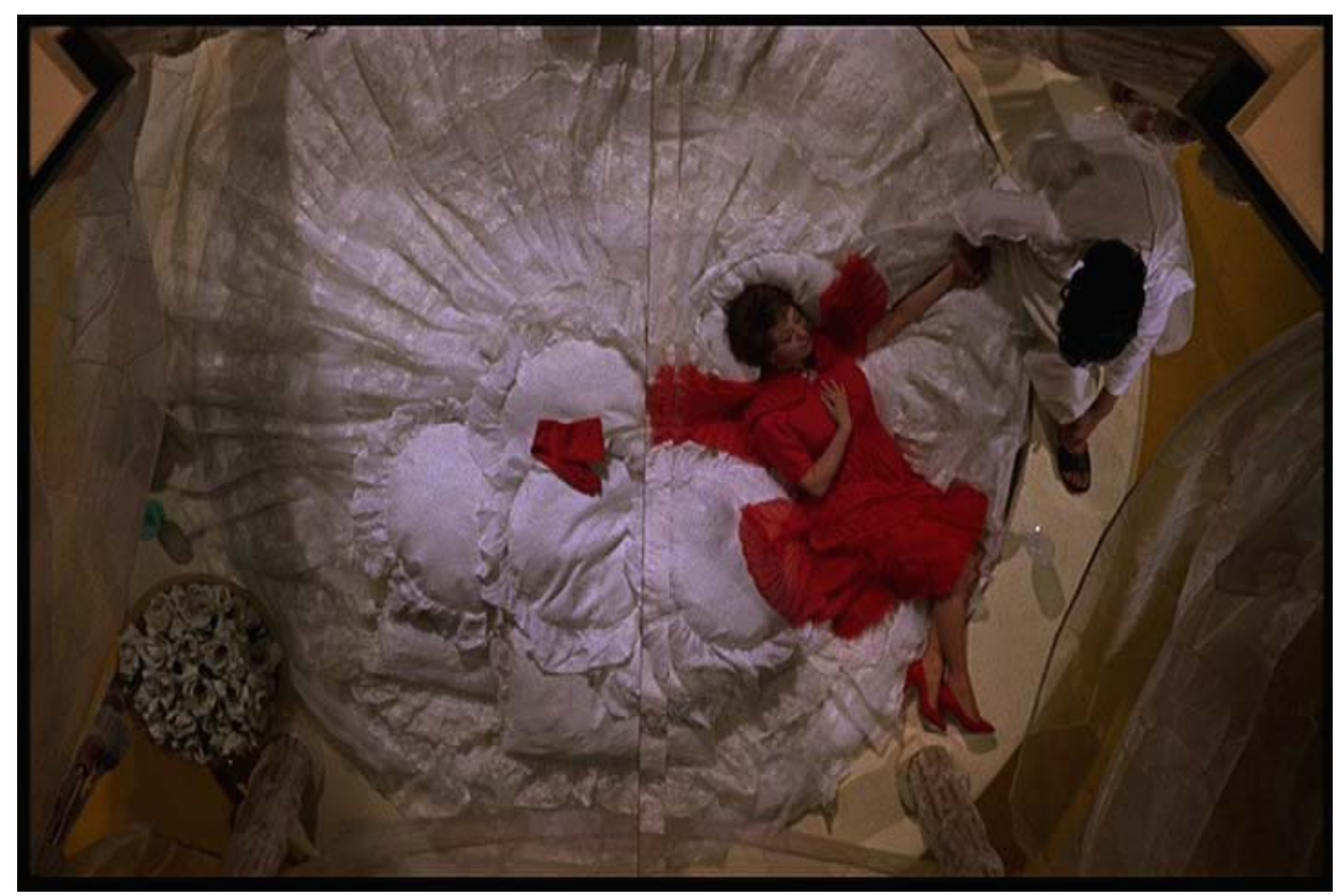

Imagem 99 Julieta na cama de Susy

Neste quadro, se pode ter uma visão superior da cama de Susy, onde Julieta está deitada segurando a mão do rapaz. Como há muitas dobras nos tecidos da colcha, das almofadas e do vestido, igualmente leves, misturando-se enquanto materiais - eles diferenciam-se apenas enquanto cor. Julieta parece surgir de uma mancha de cor vermelha, ou, se lembrarmos da primeira 
sequência no quarto da protagonista, em que a "serpente da sexualidade" escorria sobre sua cama, fora de contato com Julieta, agora a "serpente" integrada-se a ela.

Nota-se aqui novamente o contraste do branco com o vermelho, Julieta mais uma vez entra em conflito, em contradição com seus sentimentos. Deseja ser amada, deseja inclusive o rapaz, mas por um desejo fugaz, puramente carnal ou imitativo em relação ao marido, que destoa de seu anseio por um amor completo, pleno. O carnal evidencia-se pelo vermelho e o espiritual pelo branco, mais uma vez.

\section{Festa na Casa de Julieta:}

Durante um encontro entre amigos na casa de Julieta, logo no dia seguinte à festa na casa de Susy, Julieta conhece a psicanalista Miller, que propõe jogos terapêuticos para quem ali se candidatasse a resolver seus traumas passados.

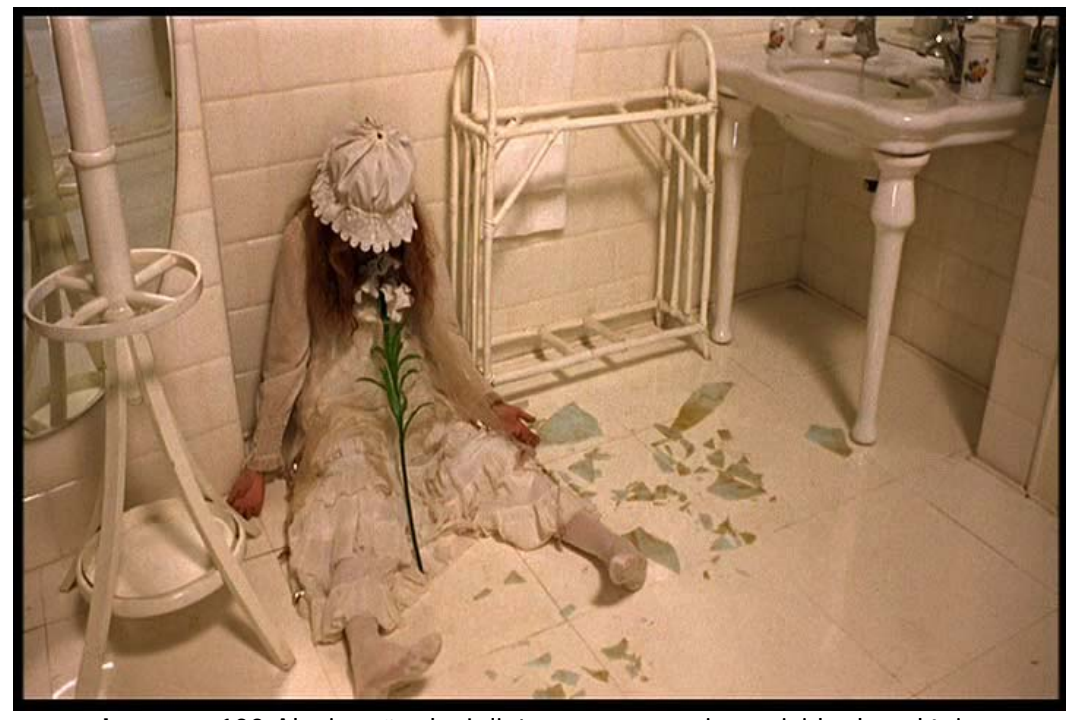

Imagem 100 Alucinação de Julieta com sua amiga suicida do colégio

Julieta está bastante confusa, tem muitas alucinações persecutórias. Muitas vezes pensa ver sua amiga de colégio que suicidou-se ainda menina, mas logo depois, a imagem se transforma no rosto de uma mulher maliciosa e muito viva, que nada tem a ver com desistência da vida, um rosto muito parecido com o da vizinha Susy e com o da Bailarina do Circo da sua infância. 


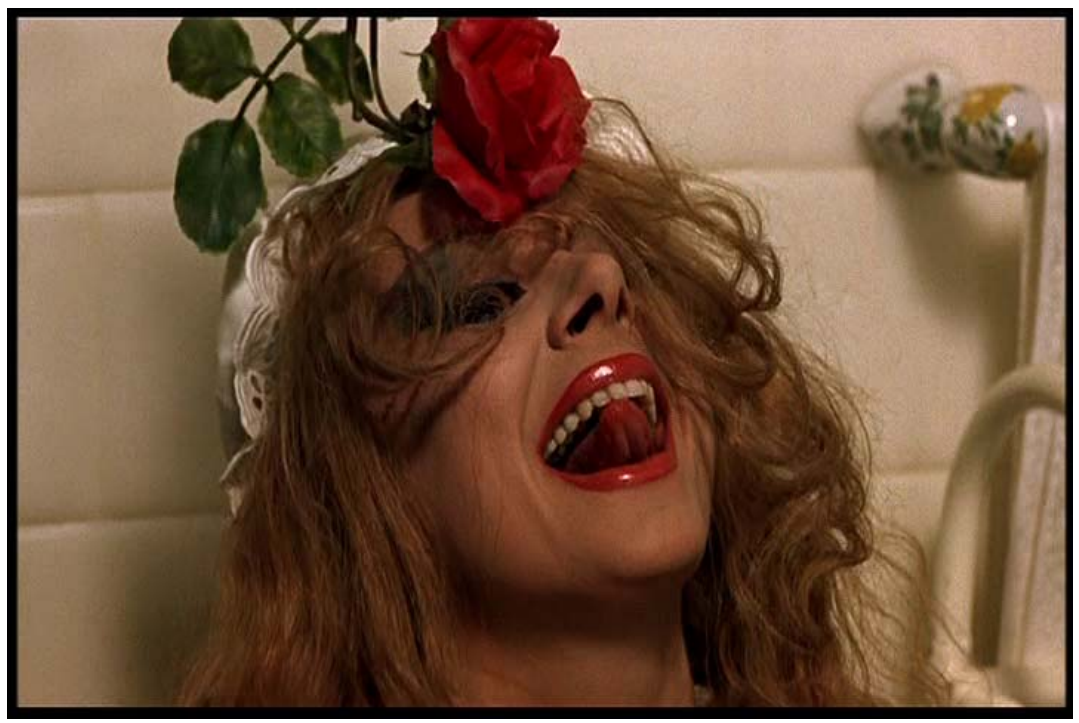

Imagem 101 A alucinação toma a feição de Susy ou da Bailarina Fanny

A cor da flor que acompanha a primeira visão é branca; a cor da flor que acompanha a segunda é vermelha, reforçando, como em diversos fotogramas analisados anteriormente, o conflito que se dá internamente em Julieta: o sacrifício mudo, submisso, ou a postura ativa, o amor verdadeiro e mais livre, a vida tomada pelas rédeas. Além disso, a primeira flor é um lírio branco emblemático de pureza, muitas vezes associado aos santos. E a segunda flor é uma rosa - largamente associada à paixão desenfreada.

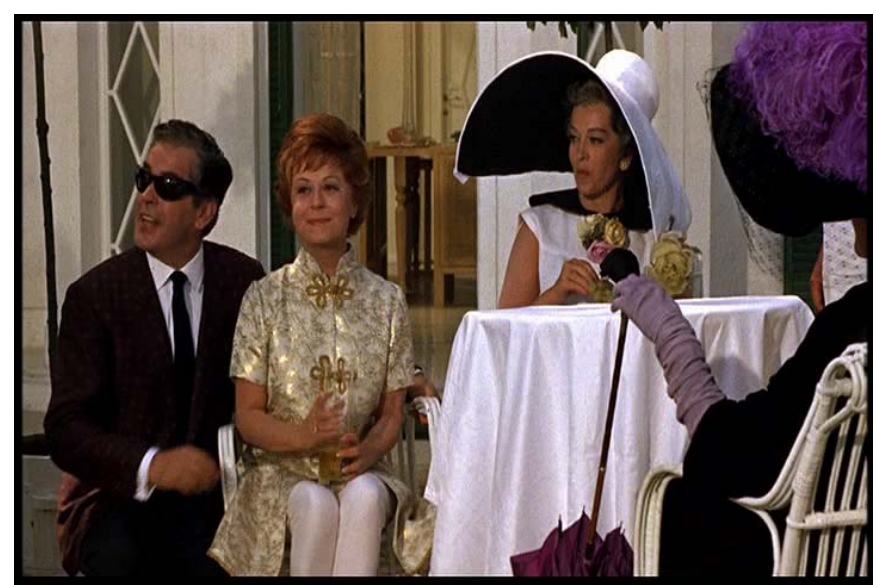

Imagem 102 Julieta e Giorgio com sua irmã Adele e mãe

Sobre seu figurino, trata-se aqui de um kimono branco e dourado que ela usa com uma calça de malha reta branca. O conjunto continua seguindo o mesmo estilo com mangas não muito curtas e decote alto, mas aqui ganha um ar mais nobre, aliando o branco ao dourado. Este traje aliado à postura da atriz, perfeitamente ereta, sua fisionomia que quer parecer sempre serena e feliz, contrasta com o estado de espírito do personagem, que se encontra 
extremamente agitado, entretanto condiz com um desejo de correspondência ao modelo de perfeição inspirado pela mãe e pelas irmãs (nunca atingido por serem completamente diferentes).

Nessa reunião de amigos, enquanto Julieta tenta se concentrar para se livrar das vozes e imagens que a estão atormentando, uma psicanalista propõe jogos terapêuticos, o que parece aumentar a intensidade do mergulho em seus próprios pensamentos. Trata-se de um questionamento sobre o quanto se dá ouvidos ao que os outros dizem e, por isso, então, não se sabe mais o que fazer, sobre o quanto se permite ser podado, que se faça interferências em nosso modo de ser e de pensar, sem que se dê a devida importância à nossa própria opinião e próprio conceito do que seria mais ético.

Dentro desta chave, vemos o quanto as pessoas buscam respostas para os seus vazios num outro, externo de si, e não em si mesmas. Por essa razão, o encontro com o grande guru acaba sendo registrado também com certa ironia por Fellini, mesmo considerando o seu gosto pelo misticismo (não acreditando nem desacreditando neles). A busca se torna tão desesperadora que é necessário que uma voz, mesmo desconhecida, interceda em nosso favor. E por que acreditar que esta voz seria mais sábia que a nossa própria?

Quando se tenta assimilar tantas opiniões externas como sendo nossas, não há perigo de não reconhecermos mais qual é a nossa própria, em meio a tantas, por tanto tempo colecionadas em nosso íntimo? É nessa crise de identidade que esbarra nossa Julieta.

Por fim, ela sai com a Dra. Miller para uma sessão informal pelo bosque. A imagem abaixo foi retirada desta seqüência, na qual as duas, como figuras muito claras, brancas, adentram a floresta escura como se fossem levar luz a um local sombrio. A floresta aqui aparece como metáfora da vegetação densa, escura e inexplorada de nosso inconsciente.

Nessa sessão informal, a especialista compara as pessoas às árvores: "Grandes árvores são o símbolo da vida. Profundamente enraizadas à terra, abrem seus ramos em todas as direções. Seu crescimento é espontâneo." Julieta, que sempre pareceu gostar do bosque, no entanto, podava as árvores de seu jardim mantendo-as sempre pequenas, com copas arredondadas, protegendo-as numa capa plástica durante a noite. A psicanalista lhe explica que "devemos aprender com as árvores a expandirmo-nos em todas as 
direções, a realizarmo-nos espontaneamente, sem conflitos com desejos e paixões". E assim, chega a uma conclusão inicialmente ridicularizada por Julieta, mas provavelmente mais tarde compreendida. Julieta apenas pensava ter medo de ser abandonada pelo marido, quando na verdade, talvez este fosse seu maior desejo e necessidade.

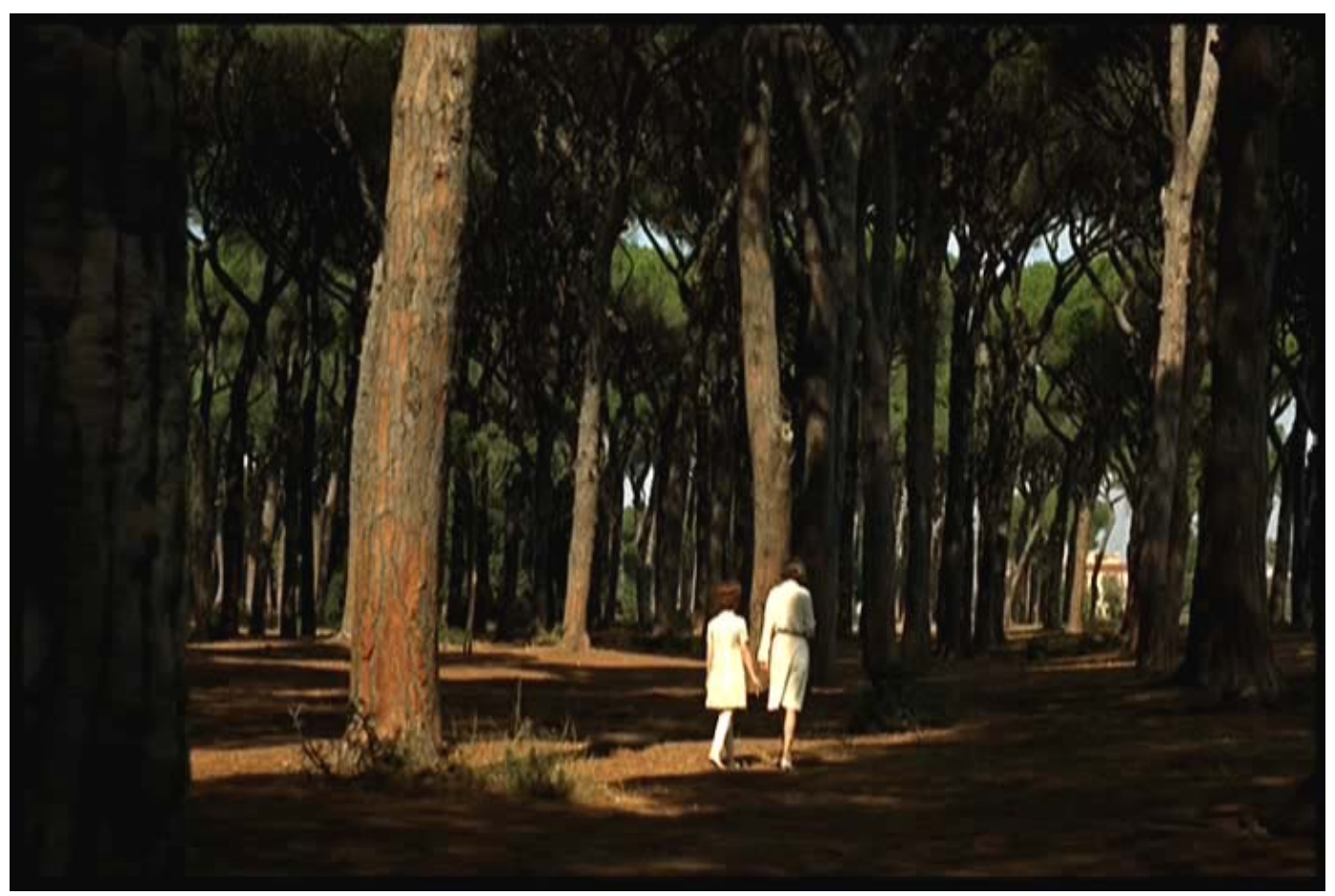

Imagem 103 Julieta e psicanalista Miller fazem uma sessão informal pelo bosque

Um depoimento de Fellini que julgo relevante sobre seu propósito com Julieta dos Espíritos e que reflete a esse respeito e a alguns outros aspectos levantados em seqüências do filme é:

A intenção, a ambição do filme, sob este ponto de vista (relação homem-mulher na sociedade), é restituir à mulher uma independência real, uma indiscutível e inalienável dignidade. O homem livre, quero dizer, não pode prescindir de uma mulher livre.

(...) A mulher livre não pode se emancipar por imitação, mas sim por descobrir uma realidade diferente, a sua realidade. Diferente daquela do homem, mas que a complementa. Seria um passo na direção de uma humanidade mais feliz. 
A única fidelidade verdadeira é aquela a si mesmo e ao próprio destino, no respeito absoluto a qualquer individualidade (FELLINI, 2004, p. 136 e 137).

\section{Cena imaginária - Julieta apresenta o noivo à Mãe e às irmãs:}

Esta cena é apenas imaginada por Julieta no momento em que Giorgio está partindo em viagem e toda a má situação do casamento já é notória para ambos. É uma cena em que Julieta submete Giorgio à aprovação da mãe e das irmãs, e indiretamente, se submete à aprovação também.

Julieta, observadora e parte integrante da cena, usa um vestido preto com bordas brancas e finas. Todas as outras pessoas se vestem com tons de cinza. Se lembrarmos do conceito de Kandinsky sobre a questão do movimento do cinza ter sido anulado pela movimentação interna das suas cores formadoras, o preto e o branco (concêntrica e excêntrica, respectivamente), chegaremos a uma interpretação que pode ser a seguinte. Aquelas pessoas estão estáticas, congeladas no tempo, da maneira como sempre foram. São como personagens chapados, sem profundidade. A cor de Julieta é diferente pois não se trata de um meio tom, é preto, uma cor inteira. Embora possa ser interpretada como passiva (no campo das cores ativas ou passivas de Goethe), manifesta um movimento concêntrico, introspectivo da personagem. A reflexão necessária para mudar de atitude, para enxergar aquele contexto como um registro antigo, já em preto e branco, ultrapassado em sua vida. 


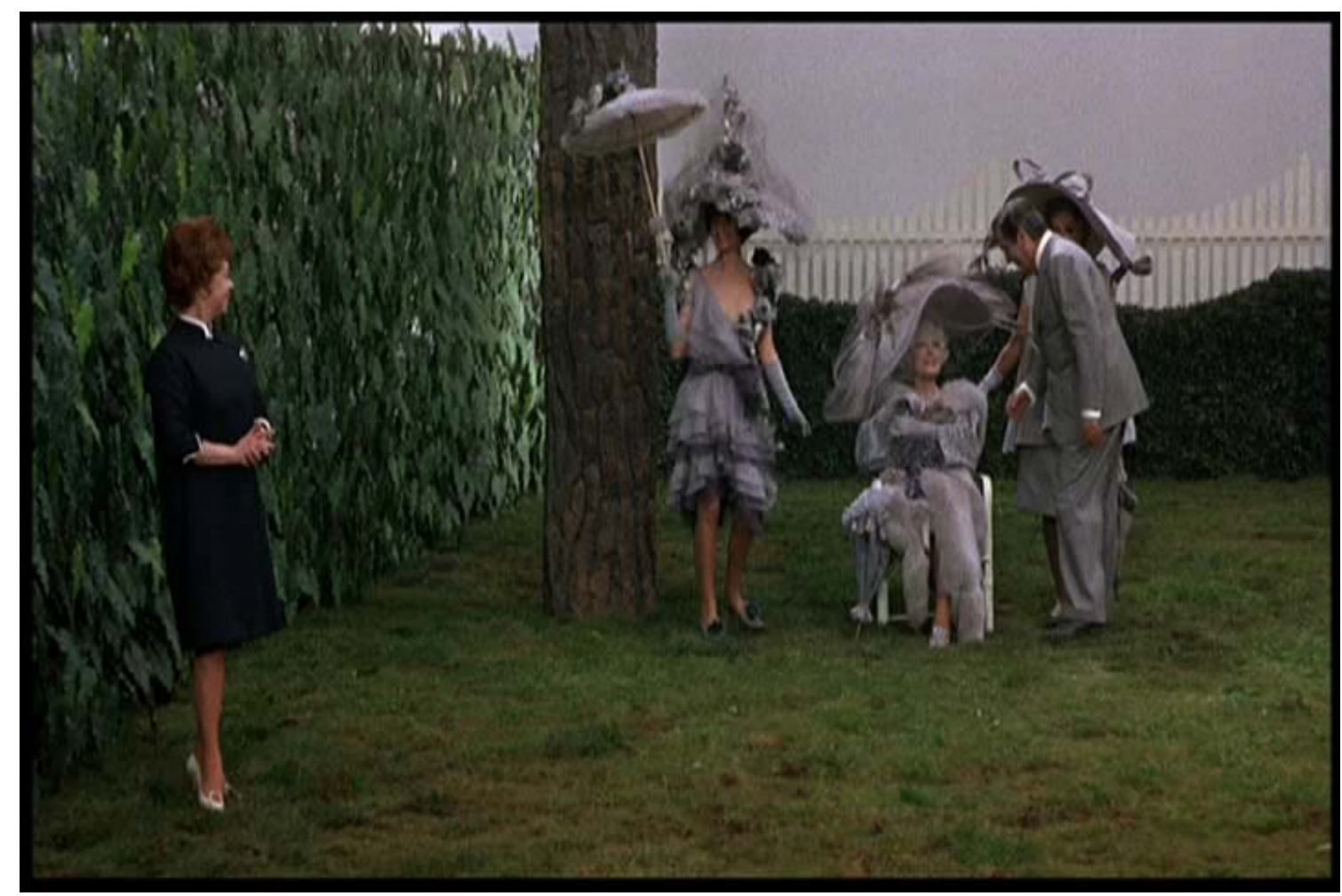

Imagem 104 Julieta à esquerda, observa Silva, mãe, Giorgio e Adele, à direita

É uma cena interessante também para percebermos mais uma vez como suas duas irmãs são moldadas à imagem da mãe - a mesma que ordena obediência e inspira medo. Julieta deve ter-Ihe obedecido durante a vida, mas surpreendentemente algo dentro dela se manteve autêntico, ela não se fez igual às outras.

\section{Partida de Giorgio:}

$\mathrm{Na}$ imagem a seguir vê-se Julieta sentada num canto de sua casa vendo seu marido partir. Há um luto do personagem pela idéia feliz de casamento que ela tinha e pensava viver. O preto aqui se torna um tom sério e sem graça, de profunda tristeza e estagnação. De colorido há apenas as almofadas do assento do banco, num tom de amarelo esverdeado e escurecido, que neste tom perde quase toda a sua alegria e jovialidade. O branco que está em todo o restante, no chão, nas paredes e na janela, está liso, limpo, sem ruídos, o que aumenta a sensação de silêncio e de solidão. O tom deste branco é escuro como um cinza, fortalecendo a tristeza da imagem. 


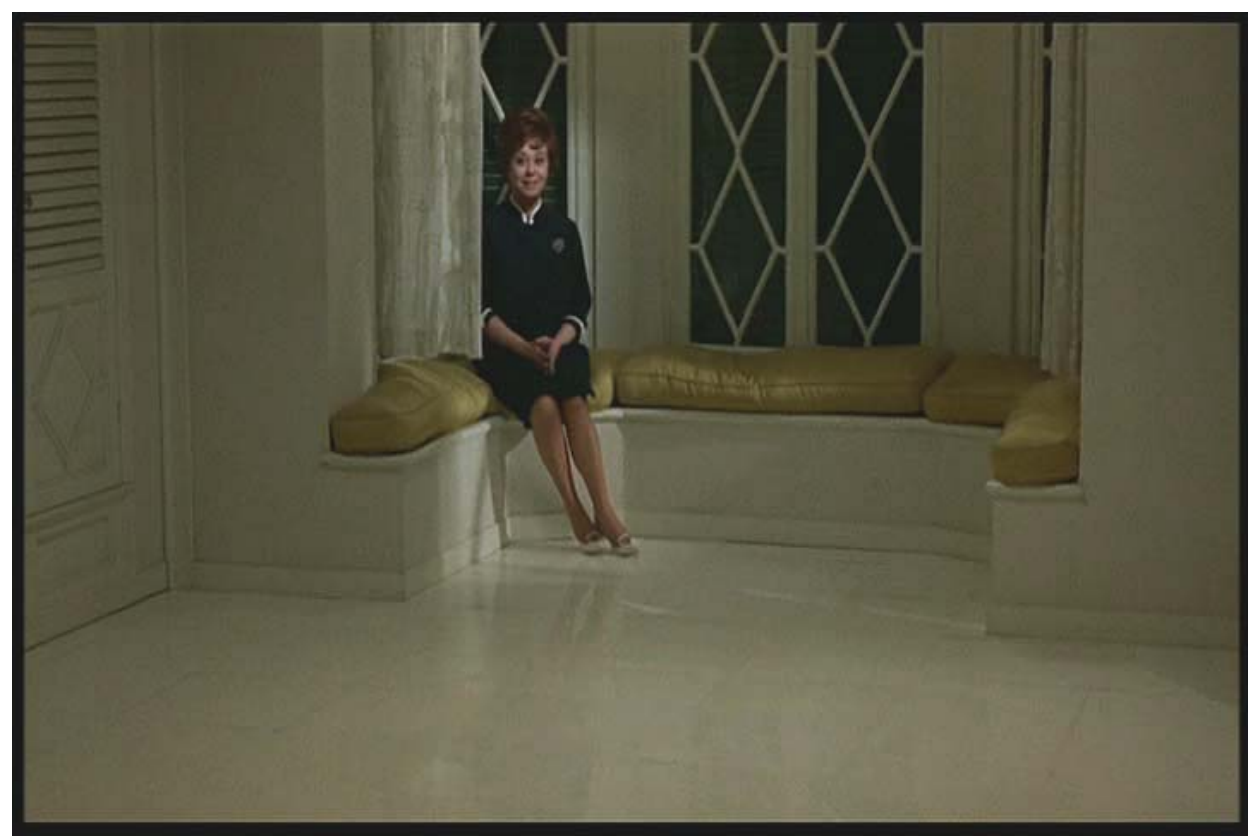

Imagem 105 Julieta sentada em sua casa vê partida do marido

\section{Mudança de postura:}

Uma entre as alucinações persecutórias de Julieta é a figura de sua mãe. O excesso de maquiagem, o excesso de adornos, o desejo de perfeição, parece constituir uma personalidade opressiva, que impõe um modelo de feminilidade fatal e blasé, que finge, que é desumana. No fotograma abaixo vemos a mãe cercada de véus em tons frios de violeta principalmente, mas também verdes e azuis. De modo geral, o violeta e os tons frios são os mais usados por este personagem ao longo do filme o que diz muito sobre a sua maneira de ser.

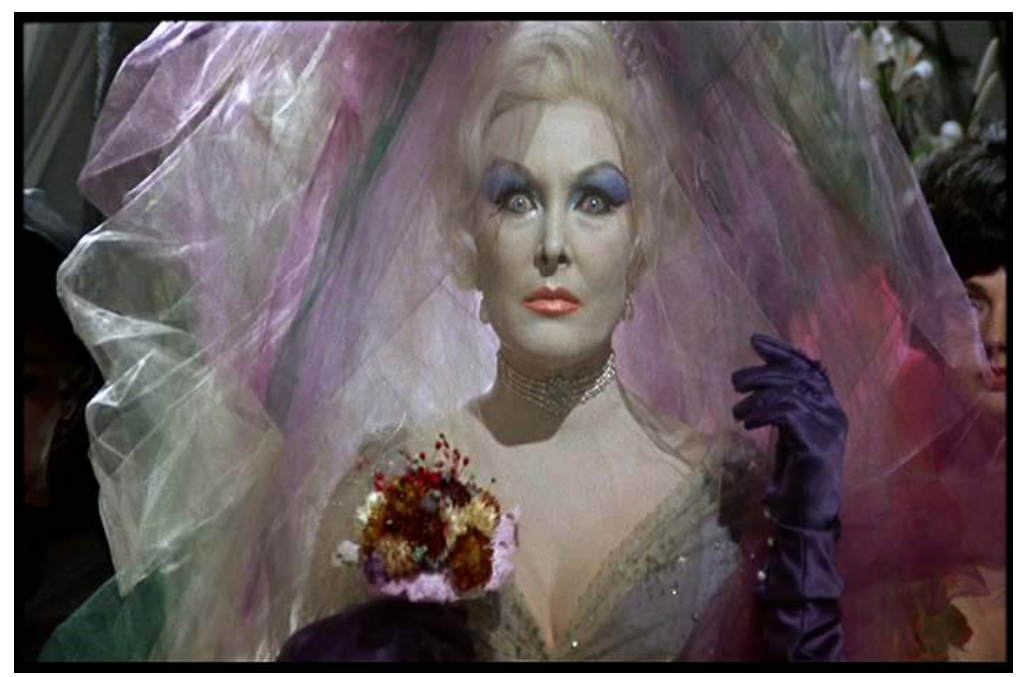

Imagem 106 Mãe de Julieta segundo sua visão

O momento a seguir é resultante do enfrentamento de Julieta: quando ela enfrenta os desmandos da mãe, esta se transforma em uma mulher comum 
e mais humana. As cores são esmaecidas, todas tendendo ao cinza, com exceção do tom da pele, que antes era branco como o de uma estátua e agora ganha vida num tom róseo. A parede amarela ao fundo também empresta a esta cena uma aparência mais quente, mais verdadeira.

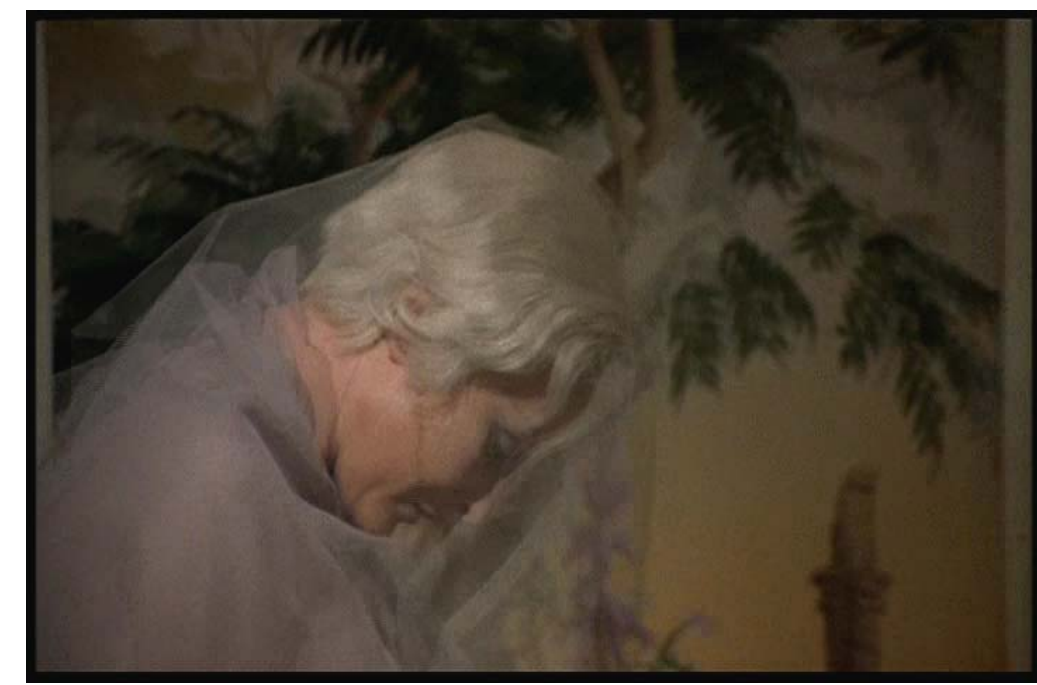

Imagem 107 Mãe após ter sido enfrentada por Julieta

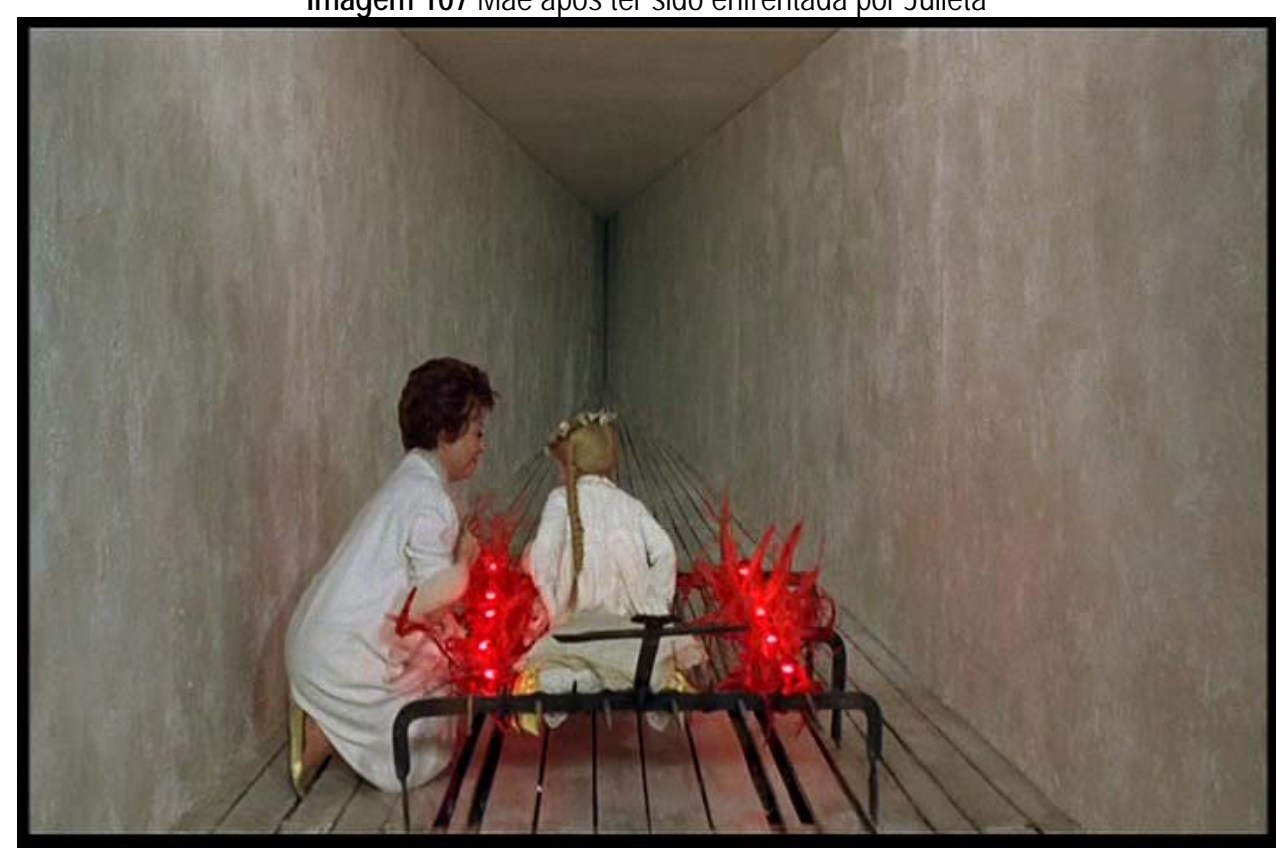

Imagem 108 Julieta se salva da fogueira - metáfora materializada

Neste quadro há uma porção de cinza cobrindo quase toda a superfície e tornando-se mais escura nas paredes em direção ao fundo. As linhas do chão e do teto, somadas a esse escurecimento nos dão uma sensação de perspectiva.

O tom neutro, cinza, faz destacar as duas figuras brancas, a Julieta-atual e a Julieta-criança, sem perder a claridade do conjunto, o que a presença do branco intensifica. O vermelho é forte e luminoso e sendo a única cor viva do 
quadro confere mais dramaticidade à cena e importância à ação de salvar a vida.

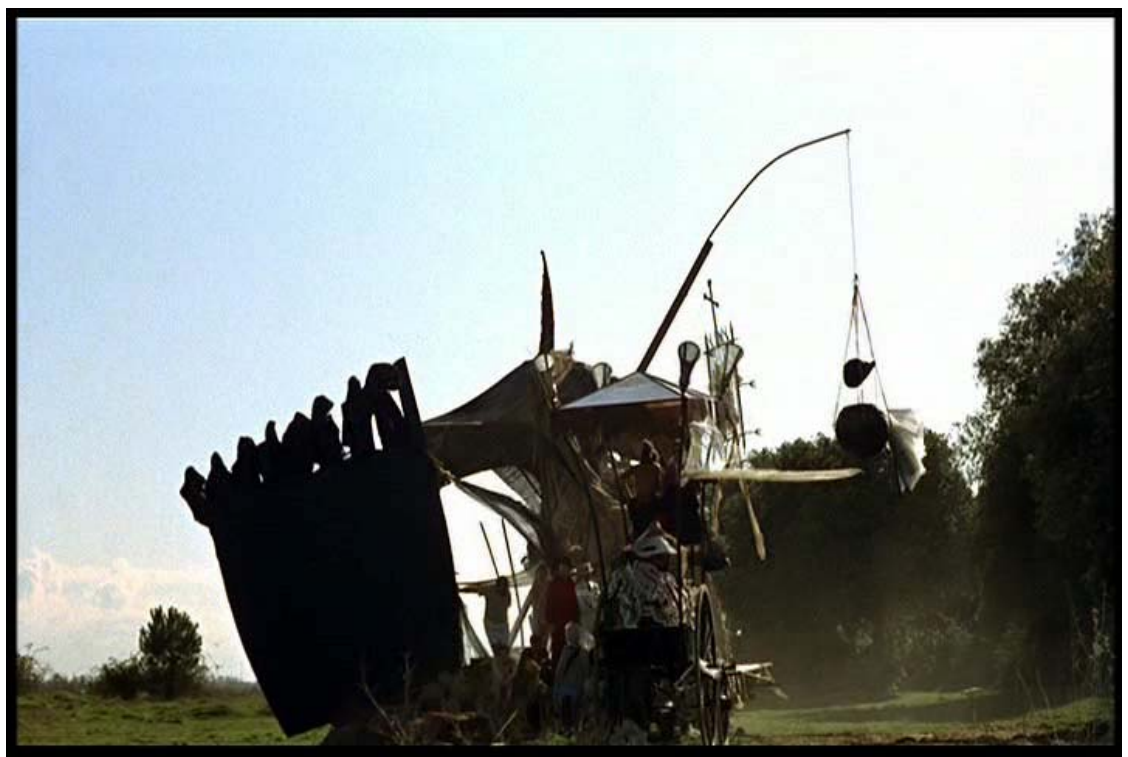

Imagem 109 Fantasmas vão embora

Após este salvamento, o desejo de manter-se fiel a si mesma se consagra, quando ela consegue, finalmente, espantar seus fantasmas atormentadores que, contra a luz, se retiram de cena - não passam de um amontoado de "cacarecos" sombrios, reduzidos a silhuetas escuras - perdem suas cores e sua vida própria.

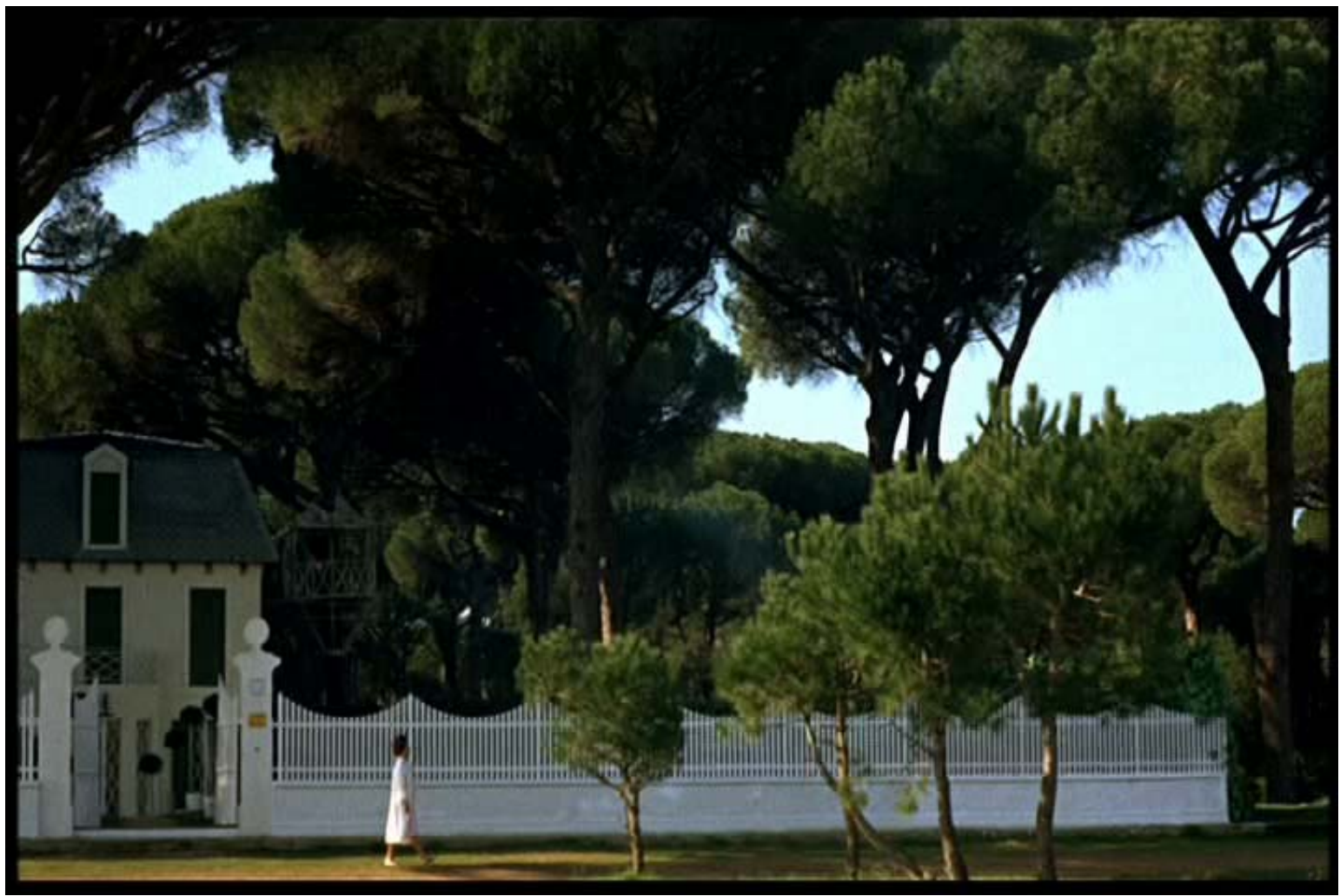

Imagem 110 Julieta sai em direção ao bosque 
Julieta então está livre para seguir em direção ao crescimento pleno ("as grandes árvores", de que esse crescimento se tornou símbolo pelas palavras da psicanalista). 


\section{PARTE C - ANÁLISE DA CONSTRUÇÃO DOS PERSONAGENS NO FILME}

TOBY DAMMIT

\section{Edgar Allan Poe}

Um dos fundadores da escrita psicológica e um dos maiores escritores de todos os tempos, Edgar Allan Poe (1809 - 1849) é autor revolucionário, de uma literatura marcada por histórias fantásticas que, se por um lado descrevem fatos sobrenaturais, continuam comprometidas com o universo humano. $O$ sobrenatural das histórias de Poe apenas personifica através das imagens, atmosferas, situações, a degradação do ser humano, sua solidão, seus medos e fragilidades. Uma construção com caráter poético, que, por isso mesmo, confere maior força e abrangência às suas obras.

O escritor mantém-se como referência em histórias de mistério. Seus enredos, repletos de elementos fantásticos e signos psicológicos, eram admirados por Fellini, e muito o influenciaram na criação de Toby Dammit, na abordagem do lado obscuro do ser humano, na construção das imagens a partir dos estados psicológicos do personagem. Sua breve existência foi também muito intensa, e está presente em tudo o que escreveu.

Poe era filho de um casal de atores americanos fracassados e ficou órfão aos dois anos por uma fatalidade. Foi então adotado por um casal inglês que the ofereceu excelente formação. Contudo, mesmo destacando-se nos estudos, conforme se tornava adulto, Poe começava a entregar-se à bebida e ao jogo, o que o fez ser expulso de uma das escolas que cursou e, mais tarde, impedido de continuar os estudos por intervenção do pai adotivo. A intolerância aos vícios do filho gerou intermináveis conflitos e o rompimento entre os dois, sendo que a única relação familiar que havia restado a Poe, também se esgotou rapidamente, com o falecimento de sua mãe adotiva um ano depois das brigas.

O escritor enfrentou dificuldades devido à sua postura rebelde e um pouco arrogante, somada ao problema com o alcoolismo, que só se agravou com o passar dos anos. Mesmo assim, foi editor de revistas respeitadas nos Estados Unidos, publicando poemas e contos, como O Escaravelho de Ouro (que the rendeu um bom prêmio, como outros trabalhos que vieram depois, 
igualmente premiados, oferecendo prestígio e publicidade ao autor), e alguns livros como Contos do Grotesco e do Arabesco (publicado na França sob o título de Histórias Extraordinárias, por Baudelaire, em 1848) um marco da literatura norte-americana.

Mas como na maioria de suas histórias, Poe teve para si um fim triste e misterioso. Acredita-se que o tenham encontrado na rua como um indigente, inconsciente por causa do abuso do álcool e outras drogas, e o tenham levado a um hospital, onde veio a falecer em 1849.

\section{O conto - Nunca Aposte sua cabeça com o diabo}

O conto Nunca Aposte sua Cabeça com o Diabo, de Edgar Allan Poe, foi publicado em 1841 na revista Graham's Lady's and Gentleman's Magazine, que o escritor editava, na Filadélfia. É um conto moral mórbido e atroz. A narração, permeada de cinismo, faz-se em primeira pessoa, sendo o melhor amigo do personagem-objeto da história a narrar a curta vida de Toby Dammit e os fatos absurdamente grotescos que o seguiram na morte.

Era um homem terrivelmente pobre, tanto de bens materiais quanto de espírito, que desde a infância manifestava tendências para todos os tipos de vícios - bebidas, jogos, mulheres -, heranças de sua mãe, que mesmo assim o castigava, surrando-o até que ele desmaiasse. Toby fracassava em suas empreitadas mais simples e tinha a irritante mania de fazer apostas vãs, na tentativa de garantir de alguma forma o sucesso de seus intentos. Como não podia apostar dinheiro, apostava "o que os outros quisessem" e mais tarde, passou a "apostar a cabeça com o diabo" como conseguiria realizar o prometia.

Certo dia, atravessando uma ponte escura com o amigo, narrador do conto, uma de suas apostas o levou ao infortúnio fatal. Ele havia apostado a cabeça com o diabo como conseguiria saltar um torniquete que obstruía a passagem e, nesse momento, surgira uma estranha figura: um velho gordo, baixo, manco e que usava sobre negros trajes distintos, um avental negro de cetim. Inesperadamente o velho produzira um som grave e seco, sorrira, aproximara-se de Toby e encorajara-o a realizar o salto. Toby, enfim, realizou a façanha, mas foi decapitado por uma barra de ferro que permanecera obscura 
durante a operação. Sua cabeça ao cair, foi envolvida pelo avental do velho que só então, saiu rápido e cambaleante em direção à luz.

O que há de mais grotesco reside no fato de que mesmo sendo amigo de Toby, o narrador pareceu achar de boa moral castigá-lo mesmo morto. Tentou primeiro reviver o corpo decapitado com homeopatias, obviamente sem sucesso (da mesma forma que não fora bem sucedido na intenção de transformar Toby em vida por meio de repreensões à sua mania de fazer apostas). Não pagou os encargos do enterro e, como ninguém se prontificasse a fazê-lo, desenterrou-o imediatamente e vendeu-o para comida de cachorro.

O diabo, numa primeira leitura, parece ser a estranha criatura representada pelo velho coxo. Entretanto, se nos detivermos um pouco mais sobre o panorama exposto pelo texto, o diabo parece estar em todo lugar, pode parecer-se com o comportamento da sociedade, com o que há de mesquinho e aterrorizante no ser humano.

Chama a atenção também que, para apostar a própria cabeça com o diabo, é preciso muito mais do que não ter nada a ser dado em aposta - é preciso não dar valor nenhum à própria "cabeça", àquilo que se é. Chama atenção para uma sociedade que se sabe imerecida de bons atributos, mas que finge merecê-los em nome das aparências. De modo que a moral e os bons costumes podem até continuar em voga, mas a ética, esta sim está em xeque.

\section{Toby Dammit - o Filme}

Ao defrontar-se com a sinopse do filme Toby Dammit, de Federico Fellini, talvez se pense que a liberdade na adaptação para o cinema foi a mais livre e completa, restando muito pouco da obra original.

O personagem e a história, embora sejam diferentes no filme e no conto, guardam semelhanças com o escritor e sua obra. O vício, uma certa degradação de si mesmo e a sensação de vazio e solidão sem parentesco no mundo estão presentes na vida de Poe, no conto e no filme. E Fellini, que quando foi realizá-lo estava se recuperando de "A Viagem de G. Mastorna" (filme não completado, por duas vezes, dificuldade que o levou a uma doença misteriosa) parecia estar num momento parecido com o de Toby Dammit. 
No entanto, Fellini se ateve às questões principais que direcionaram 0 conto de Poe. O texto, como abordado no tópico anterior, colocara em foco a ética (pessoal, social) em oposição à moral aceita pela sociedade conformista e regida muito mais pelas aparências. Poe colocara a figura de um homem, Toby, já excluído e desconsiderado em todos os âmbitos desde o início de sua existência. Sem ter tido nenhuma estrutura que possibilitasse seu crescimento, não evoluiu nem construiu para si nenhuma identidade, e seu modo de agir e de viver simplesmente incomodava aos demais. Ao mesmo tempo, os que tiveram seu crescimento estruturado pela sociedade, apenas o tiveram nas aparências ou de maneira insuficiente, já que na prática não conseguiram discernir o inadmissível, nem muito menos viabilizar meios éticos e eficazes de transformação.

No filme, Toby Dammit é um famoso ator, reconhecido por sua interpretação de Hamlet, de Shakespeare, e que se encontra numa fase crítica de sua carreira, o que parece estar afetando também seu equilíbrio pessoal. Em meio a essa crise, mesmo intuindo que o melhor seria permanecer onde estava, acaba cedendo ao convite para ir a Roma em troca de uma Ferrari último modelo, dada pela produção de seu novo filme, cujo contrato de trabalho ele está prestes a assinar.

Esta relação de troca se assemelha na verdade a uma relação de venda ou chantagem que, quando vista em conjunto com o diabólico padre que coordenará o filme ${ }^{28}$, remete-nos a uma relação faustiana. Tanto aqui quanto no Fausto de Goethe, o personagem principal acaba perdido de si mesmo não só pela ambição, mas também por sua vaidade.

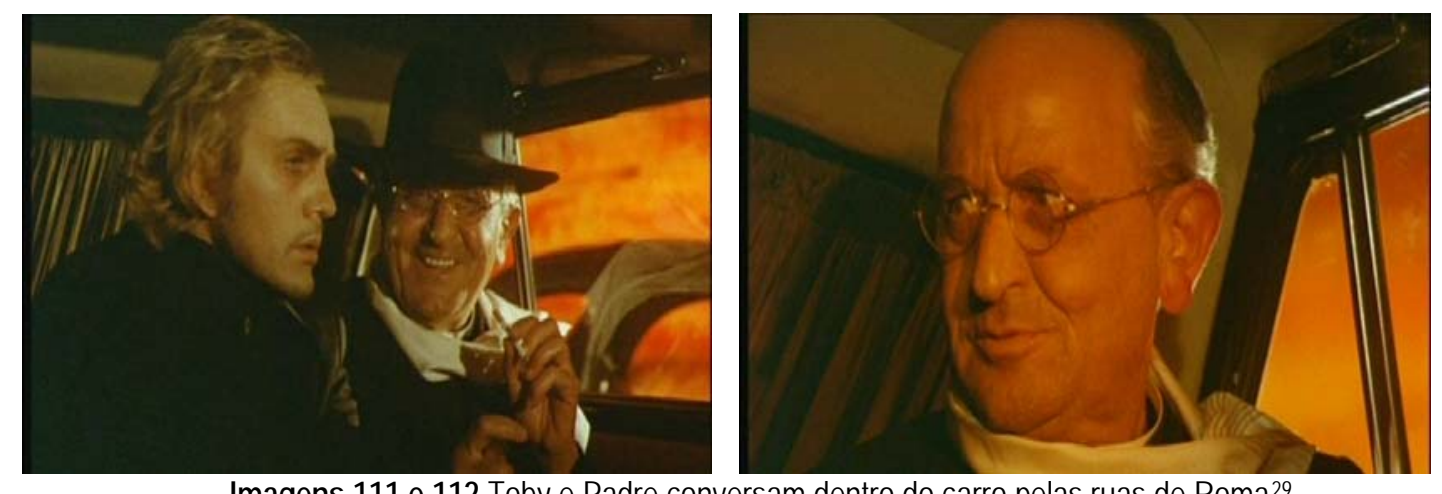

Imagens 111 e 112 Toby e Padre conversam dentro do carro pelas ruas de Roma ${ }^{29}$

\footnotetext{
${ }^{28}$ Mais uma vez, a Igreja intervindo até no Cinema: trata-se do primeiro faroeste católico da história.

${ }^{29}$ Todas as imagens do filme Toby Dammit nesta análise são fotogramas extraídos do próprio filme em questão.
} 
"Roma", a "Ferrari" e os elementos religiosos, fortemente presentes, aparecem como ícones emblemáticos da cultura italiana, por demais idealizados. De algum modo, nenhum deles parece ser o que promete - Roma mais se parece com um inferno contemporâneo, o padre aparenta ser diabólico e a Ferrari, mesmo com toda a sua potência, não pode levar Dammit aonde ele quiser.

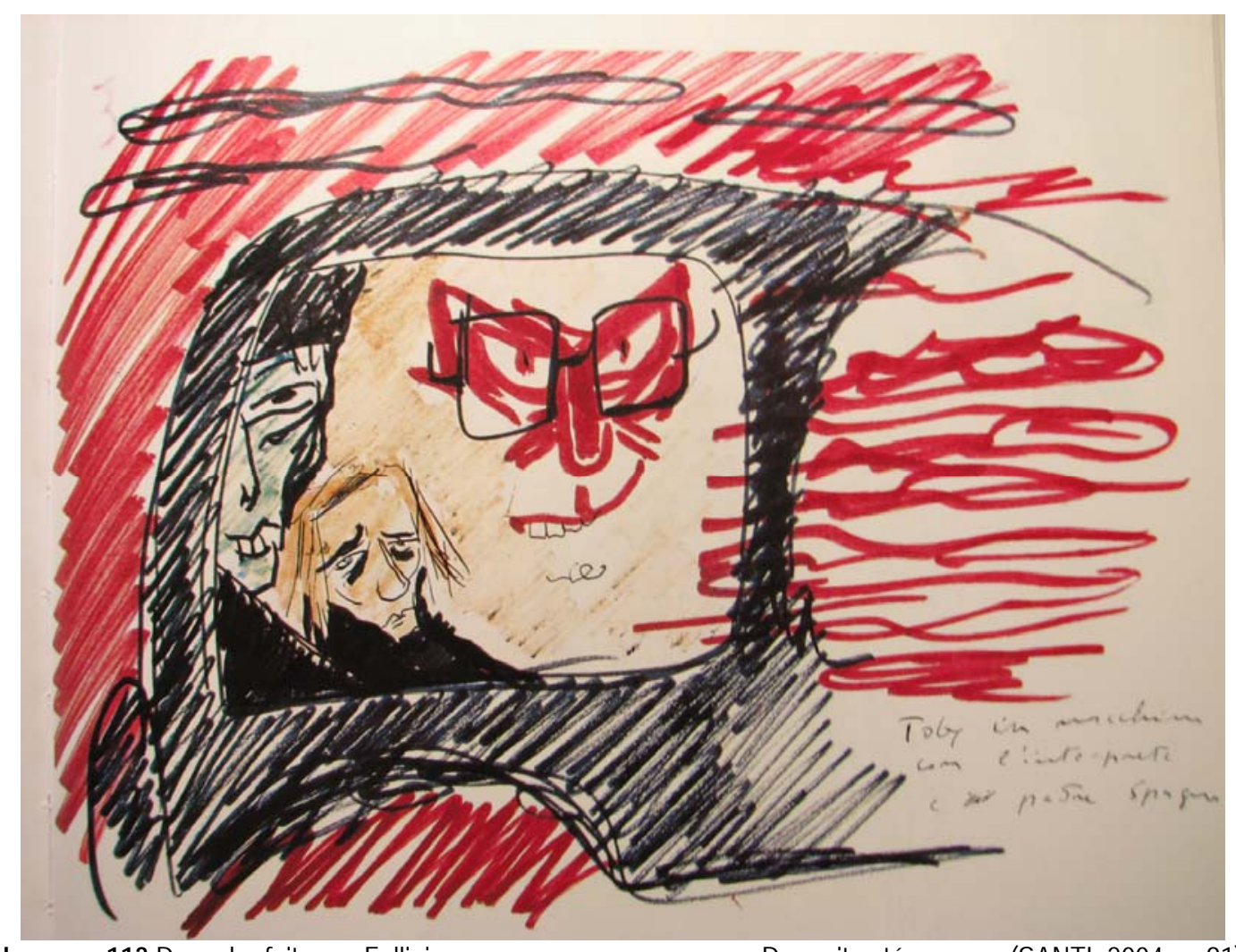

Imagem 113 Desenho feito por Fellini para a mesma cena em que Dammit está no carro (SANTI, 2004, p. 91)

Visualmente, podemos fazer as correspondências do padre ao diabo quando vemos Toby mergulhado em sonhos, pensativo no banco do carro enquanto as encenações e fisionomias da equipe e, principalmente as do padre, com olhos atentos e brilhantes ao falar de como farão o filme ou com sua boca cheia de cinismo e fumaça, sorrindo ao combinar a entrega da Ferrari. Além disso, toda a cena está mergulhada numa iluminação exageradamente alaranjada, quase apocalíptica, e num desfile caótico de horrores e banalidades durante todo o caminho, sem afetá-los.

Ao observarmos o desenho feito por Fellini para esta mesma cena, entendemos como essa interpretação havia sido, desde o princípio, pretendida. O carro é sombrio, a mulher que está ao seu lado é fria e exala uma certa 
maldade, o padre perde os contornos do corpo fazendo com que a dimensão de sua fisionomia com grandes olhos "maus" se expanda dominando o ambiente e quem faz parte dele.

Do mesmo modo, a freqüente aparição da Menina-Diabo parece cobrar alguma coisa que lhe foi oferecida na figura da bola que ela arremessa em sua direção. O sucesso e o reconhecimento do público à sua interpretação de Hamlet teriam sido oferecidos em troca do sacrifício de sua paz de espírito ou da própria alma? Estaria Dammit sendo atormentado pela cobrança de uma dívida adquirida com o diabo? Seu sucesso estaria suspenso enquanto ele continuasse em débito?

Ou o fracasso e morte da figura transgressora de Dammit seriam um bode expiatório para todas as frivolidades do meio, para que o mundo continuasse girando do modo como sempre girou, sem que nada incomodasse ou desvelasse falsas aparências $?^{30}$

Num ato de extrema transparência, no momento em que está sendo homenageado com a "Loba de Ouro"31 por sua carreira, assume publicamente não ter conseguido nenhum outro trabalho nos últimos tempos, desde que o diretor de seu último filme o demitira por estar bêbado ${ }^{32}$.

Dammit olha para todos os lados e nada parece ser real, tudo parece ter sido ensaiado, todos parecem vestir máscaras e encenarem uns para os outros. Sua atitude, única na noite, expõe uma verdade desagradável além de pôr em dúvida o valor do prêmio, como se provavelmente nem tivesse sido avaliada a qualidade artística de quem viesse a recebê-lo. As pessoas ali presentes não estão interessadas em manifestação de cultura, tudo se resume a um grande desfile de vaidades (antecipado até pelo desfile de moda na abertura da premiação). O que fica mais saliente, pelo exagero, são as roupas, as maquiagens, os penteados, as "micagens" - tudo aquilo que se coloca por cima, que se molda na superfície, encobrindo o conteúdo, que não é visto, mas pode ser pressentido.

\footnotetext{
${ }^{30}$ Um outro sub-texto pode ser reconhecido no personagem shakespeareano evocado como principal trabalho no repertório de Dammit. Hamlet era também um personagem atormentado por visões e fantasmas que chamavam atenção para a sua vida que estava em jogo. Talvez Dammit o desempenhasse tão bem por causa desta afinidade.

${ }^{31}$ Mais um símbolo da cultura italiana, referindo-se à escultura da Loba Capitolina, escultura etrusca do século $V$ a.C.

${ }^{32}$ Novamente uma identificação com o histórico de vida de Edgar Allan Poe.
} 
Essa suspeita de tudo não passar de representação, chega ao ápice quando Dammit tenta fugir da festa em sua Ferrari e se perde na cidade labiríntica e quase inabitada, mais parecendo um cenário, com bonecos e adereços.

O modo como são construídas as imagens que vemos através dos olhos de Dammit (há muitos planos subjetivos, explícitos ou implícitos), revela sua sensação em relação a tudo o que provoca dissabor no mundo ao redor, as tradições e comportamentos engessados, a pequenez de pensamento dos homens que não se entendem, que não enxergam, nem percebem que se torna cada vez mais sombria e aterrorizante a realidade que os permeia. Por isso suas visões estão sempre distorcidas em relação à normalidade, ao senso comum, mas são também mais afiadas, como se pudessem ser a extensão do próprio pensamento do personagem. Essa forma de construir o filme em muito se aproxima do conceito de monodrama proposto por Craig, durante a montagem de Hamlet, no Teatro de Arte de Moscou, em 1911. No monodrama de Craig, tanto os cenários quantos os outros personagens da peça eram compostos segundo o ponto de vista do protagonista e seus estados de espírito.

A cidade em que Dammit se perde, pode ser a metáfora da realidade em que ele está inserido, da qual não consegue fugir e que, ao mesmo tempo, repulsa. Por outro lado, como o pacto com a Menina-Diabo parece ter acontecido desde antes da viagem à Roma, podemos pensar que o fato dele não conseguir encontrar o caminho de volta, também poderia ser resultado de forças ocultas, de uma cilada armada pela própria Menina-Diabo, que se faz de isca para chamar o personagem à morte. O avanço tecnológico que se nota, no início do filme, pelo
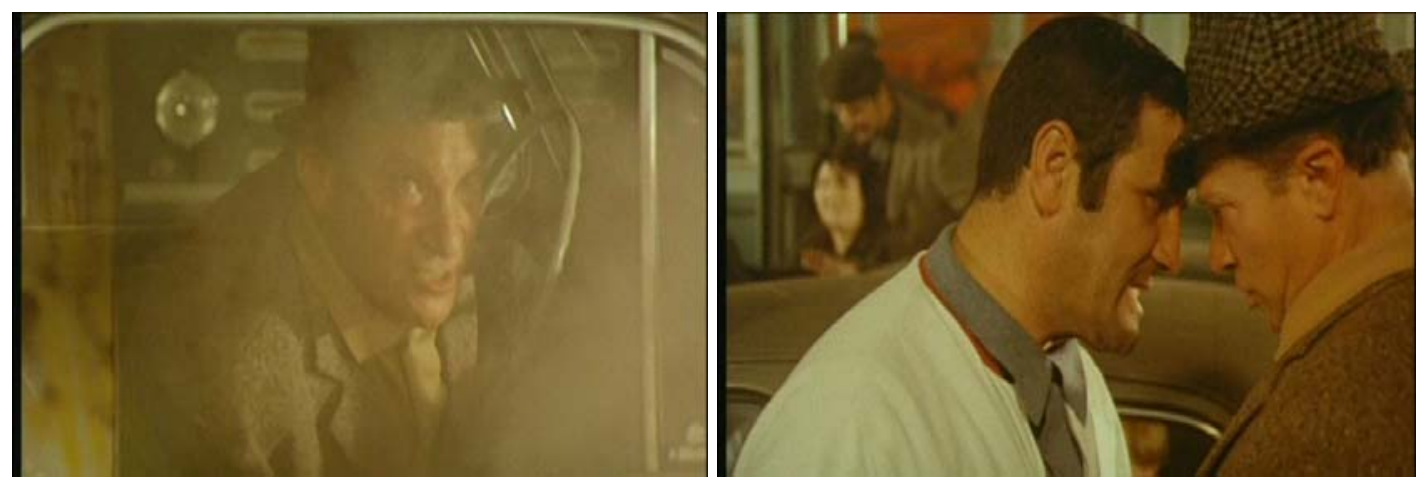

Imagens 114 e 115 Pessoas enfurecidas no caótico trânsito de Roma 
uso descontrolado de automóveis, sem nenhuma racionalização, leva os homens a se tornarem animalescos, num retrocesso.

A modernização dos meios de comunicação, apresentada na figura do meio televisivo que Fellini ironiza, não é mais que uma fábrica de produtos manipuláveis, confeccionados de acordo com uma fórmula e uma ideologia pré-estabelecidas e fora de questão, condicionadora de pessoas como bonecos sem raciocínio. Podemos notar que no estúdio, a modelo de dona-decasa se move como um manequim no cenário anexo ao da entrevista com Dammit, e os funcionários que "operam" os aplausos do alto, usam jaleco como se fossem cientistas testando e observando resultados numa experiência com ratos.

As críticas são irônicas como Dammit e a realidade que se mostra parece ser tão repulsiva quanto o personagem que a vê. Há ironia ácida em relação a tudo o que se encontra ultrapassado, ou seja, falso. O filme foi produzido na segunda metade da década de 60 e está sintonizado com sua época, quando os mais fervorosos protestos foram feitos contra os poderes controladores exercidos pela Igreja e pelo regime político, contra tudo o que fosse antinatural, etc. Além, é claro, da descriminalização do uso de drogas alucinógenas como LSD, que o próprio diretor, como já foi dito, chegou a fazer uso acompanhado por médico, para perceber as cores com mais intensidade e utilizá-las com maior ousadia e liberdade nos filmes (os dois primeiros, Julieta dos Espíritos e Toby Dammit), que agora deixavam de ser obrigatoriamente em preto e branco.

E finalmente, se em todos os filmes de Fellini existe algo de autobiográfico, neste, podemos lembrar que Felllini estava tentando se recuperar de duas tentativas frustradas de filmar A Viagem de G. Mastorna. O projeto (que não foi realizado) significava tanto para o diretor que ele confessou ter colocado um pouco dele em cada uma de suas obras posteriores. Era uma idéia antiga, acalentada desde os seus 18 anos, quando ainda morava em Rimini. Seu tratamento final transformou-se em história em quadrinhos, por Milo Manara ${ }^{33}$ e contava a trajetória de um violonista que voltava do além para

\footnotetext{
${ }^{33}$ Milo Manara é desenhista italiano de história em quadrinhos, ilustrou várias histórias de Fellini, inclusive transformou em HQ o roteiro de $A$ Viagem de $G$. Mastorna, filme inconcluso do diretor. É especialista em histórias de erotismo fantástico.
} 
entender os erros de sua vida. O mistério cercava não somente o roteiro; na ocasião da segunda tentativa de produção, padeceu de um mal súbito que o levou ao hospital. Recebera então de um médium o alerta de que se insistisse no projeto, morreria.

Além desta frustração, Fellini recuperava-se também do lançamento de Julieta dos Espíritos (outra obra repleta de alucinações fantasmagóricas) que não havia atingido suas expectativas em relação ao reconhecimento do público.

Toby Dammit surgiu neste contexto, num espaço de 3 anos desde a última produção. Fellini estava em uma fase difícil, em que parecia temer a concretização de novas histórias, de novos filmes. Profissionalmente, o diretor estava em uma fase como do próprio Dammit. Talvez pudesse comparar o tormento recorrente da aparição da Menina-Diabo à recorrente tentação de realizar o antigo projeto "Mastorna"34.

\section{Figurinos e Cenários}

Serão abordados agora os dois figurinos principais e em seguida, um panorama dos cenários e figurinos dos outros personagens, na seqüência em que eles aparecem no filme. A análise das cores se baseia no estudo da linguagem e ação das cores proposto por Kandinsky em seu livro Do Espiritual na Arte (KANDINSKI, 2000) e na análise integrada do filme com os outros elementos.

\section{Figurinos}

\footnotetext{
${ }^{34}$ O nome já apresenta um trocadilho "Mas torna (retorna)"?
} 


\section{Toby Dammit}

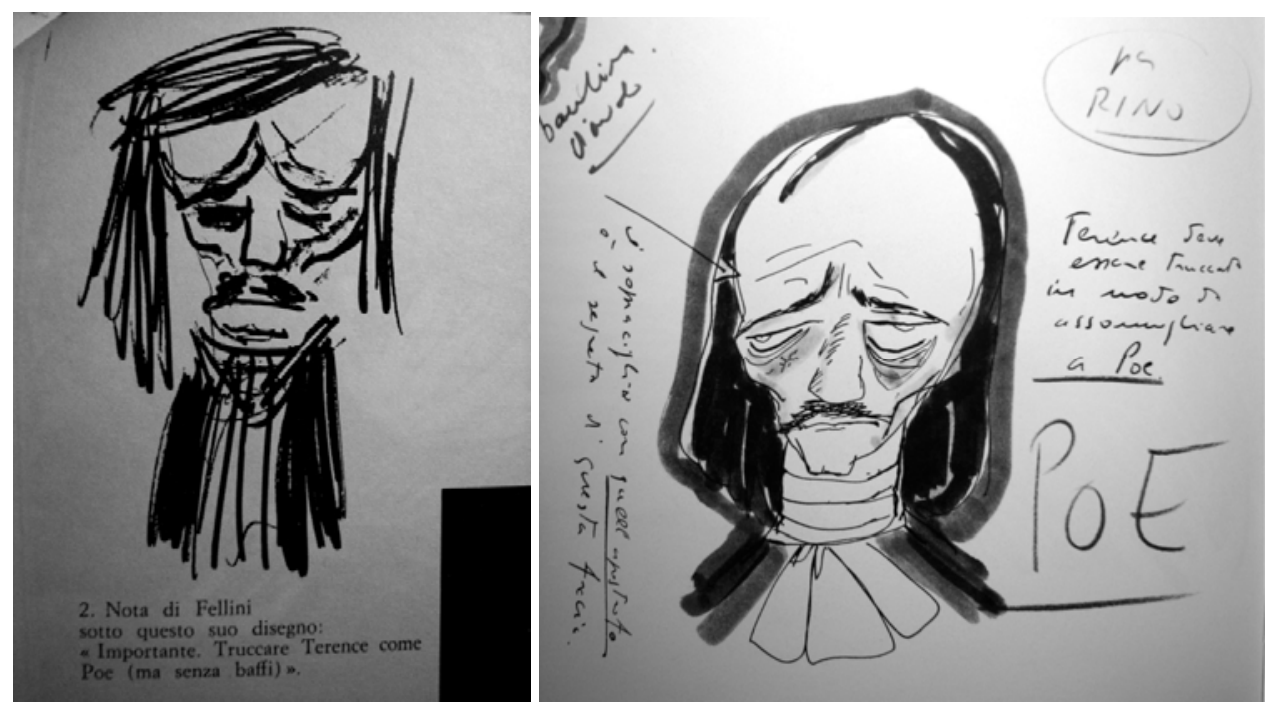

Imagem 116 Desenhos de Fellini para personagem Toby Dammit, baseando-se na imagem de Poe (FELLINI, 1979) Imagem 117 Desenhos de Fellini para personagem Toby Dammit, baseando-se na imagem de Poe (SANTI, 2004, p. 92)

Durante toda a história, vemos um personagem desencantado, perseguido por suas alucinações e, da mesma forma como seu estado de espírito não se altera muito, também não há muitas mudanças em seus figurinos. Os trajes foram compostos no desejo de evocar a imagem de Edgar Allan Poe, assim como a conhecemos através das poucas fotos que existem do escritor, o que se somou a alguma influência da moda da época (final da década de 1860).

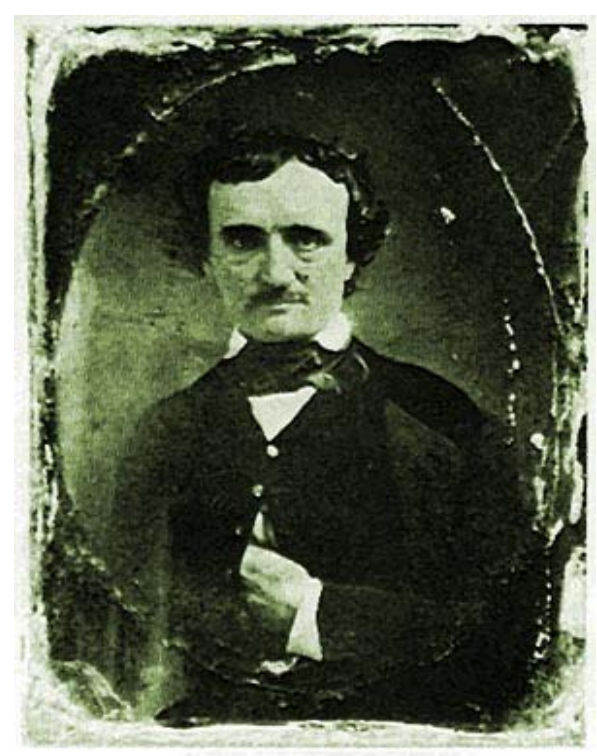

Imagem 118 Uma das únicas imagens do escritor Edgar Allan Poe ${ }^{35}$

O primeiro figurino de Toby Dammit é quase totalmente preto. É um casaco comprido preto, com botões grandes e pretos, está fechado, de modo que só vemos um pedaço do branco dos punhos da camisa, aparentes próximo às mangas do casaco. Na gola, um lenço preto amarrado com um nó, à semelhança de Poe. Usa também uma calça preta com riscas de giz, padrão geralmente masculino, usado para denotar inteligência e elegância. Finalizando o traje, sapatos de couro pretos.

35 Foto do escritor em: POE, Edgar Allan. Histórias Extraordinárias. Tradução de Breno Silveira e outros. São Paulo, Abril Cultura, 1978. 

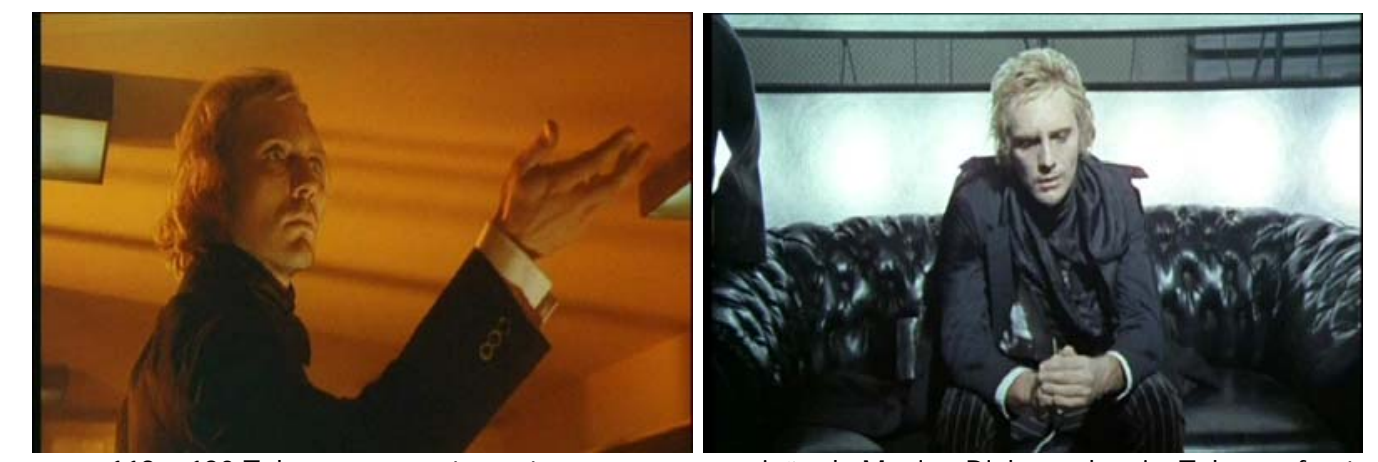

Imagens 119 e 120 Toby no aeroporto contracena com sua visão da Menina-Diabo e, depois, Toby em frente às câmeras em programa de TV

A segunda variação do figurino aparece só na festa da premiação, quando ele veste camisa branca, o lenço preto amarrado da mesma maneira que antes, os mesmos casaco preto e sapatos e uma calça de cetim roxa.

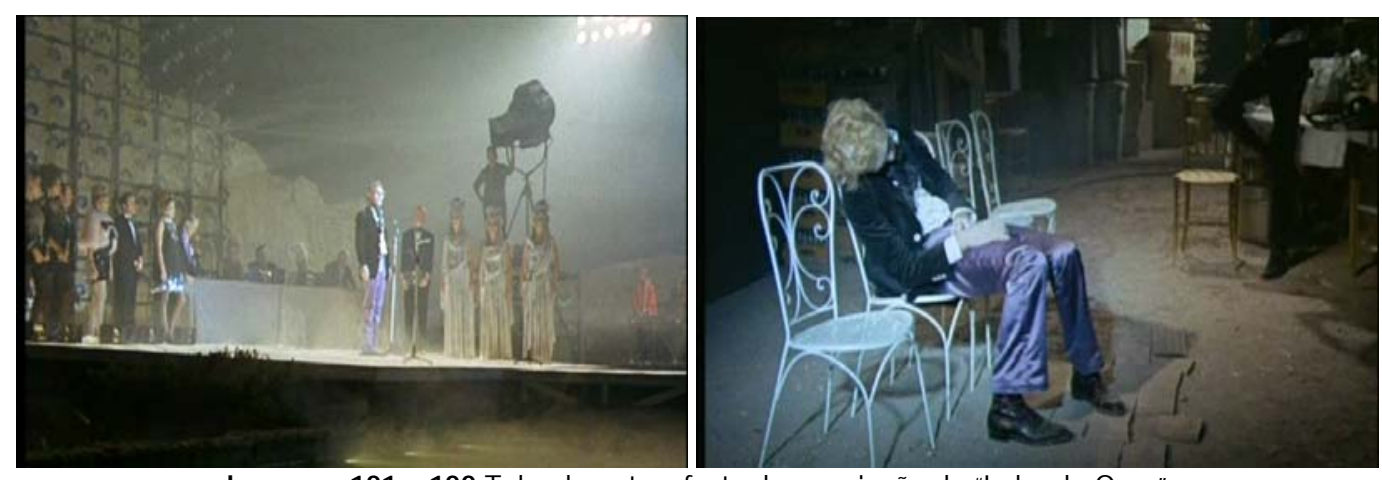

Imagens 121 e 122 Toby durante a festa da premiação da "Loba de Ouro"

Se formos pensar nas cores empregadas, podemos levar em conta 0 fato de que o figurino foi reproduzido à semelhança dos de Poe e por isso eram escuros. Mas não é suficiente. Não se trata de cinza escuro, de um azul marinho profundo. É preto, e esta cor simboliza o repouso absoluto sem possibilidade de renascimento, a morte, o silêncio que encerra (KANDINSKI, 2000 , p. 96). No entanto dá também destaque ao branco dos detalhes da camisa que salta do preto como que na tentativa de bem apresentar a pessoa envolvida neste branco, clareando sua fisionomia e oferecendo talvez um contraponto. O roxo, que é a única cor viva usada pelo personagem, é resultado da cor vermelha (quente) esmaecida pela cor azul (fria). É uma cor triste, nesta tonalidade apresenta-se mais fria do que quente e se adequa à atmosfera falsa da festa, além de antecipar algo sobre sua morte, já que em algumas culturas, como a ocidental, o roxo também representa luto (IDEM, p. 99 e 100). Os figurinos deste cenário são todos predominantemente pretos, com detalhes em branco ou prata, e quando têm cor, são tons azuis ou roxos. 
Nada é aconchegante, e também os brilhos metálicos dos paetês nos remetem a sensações de frio tátil.

Aumentando a sensação de estranheza, de frieza e deslocamento, a iluminação desta cena é tão irreal quanto a do aeroporto, mas agora é pouco iluminada, é pontual. Ora provoca efeitos de contra-luz, tornando as figuras apenas silhuetas sem nenhuma identidade (combinando com a maneira como se comportam), ora a luz incide sobre um grupo de pessoas, um pouco esfumaçada. De onde vem esta fumaça? É uma fumaça de frio? De umidade? De poeira?

Com relação à fisionomia de Dammit, uma maquiagem macilenta foi criada para que parecesse sempre pálido, doentio, como se estivesse passando mal, com olheiras profundas. Um aplique na sobrancelha direita, que a estica como uma dúvida constante a martirizar seu semblante, enfatiza o desequilíbrio do personagem. Os cabelos são descoloridos, pois Fellini queria dar a ele um visual pop, bem ao gosto dos grupos musicais da época - os Beatles são lembrados duas vezes durante o filme, quando vemos a banda vestida como no álbum Stg. Peppers e os músicos que vemos nas ruas de Roma vestidos ao mesmo modo.

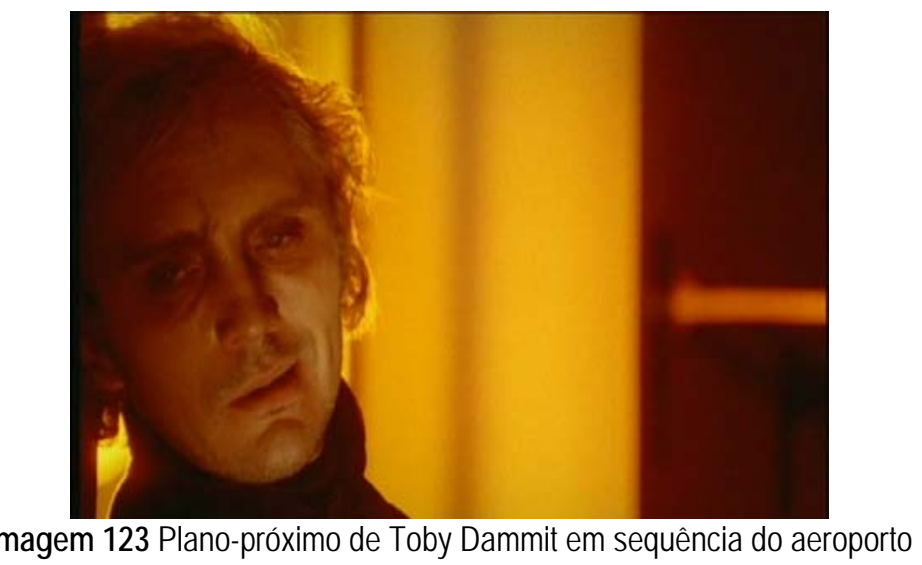

\section{Menina-Diabo}

O personagem da Menina-Diabo é correspondente ao personagem do Velho baixinho do conto. O Velho é o único cujo figurino é descrito por Edgar Allan Poe e por isso podemos estabelecer uma analogia completa, na qual percebemos que suas construções são opostas em alguns quesitos: [feminino, infantil, branco] X [masculino, velho, preto] e concordantes no que diz respeito 
ao mistério na maneira como surgem, e no fato de roubarem para si a cabeça do protagonista.

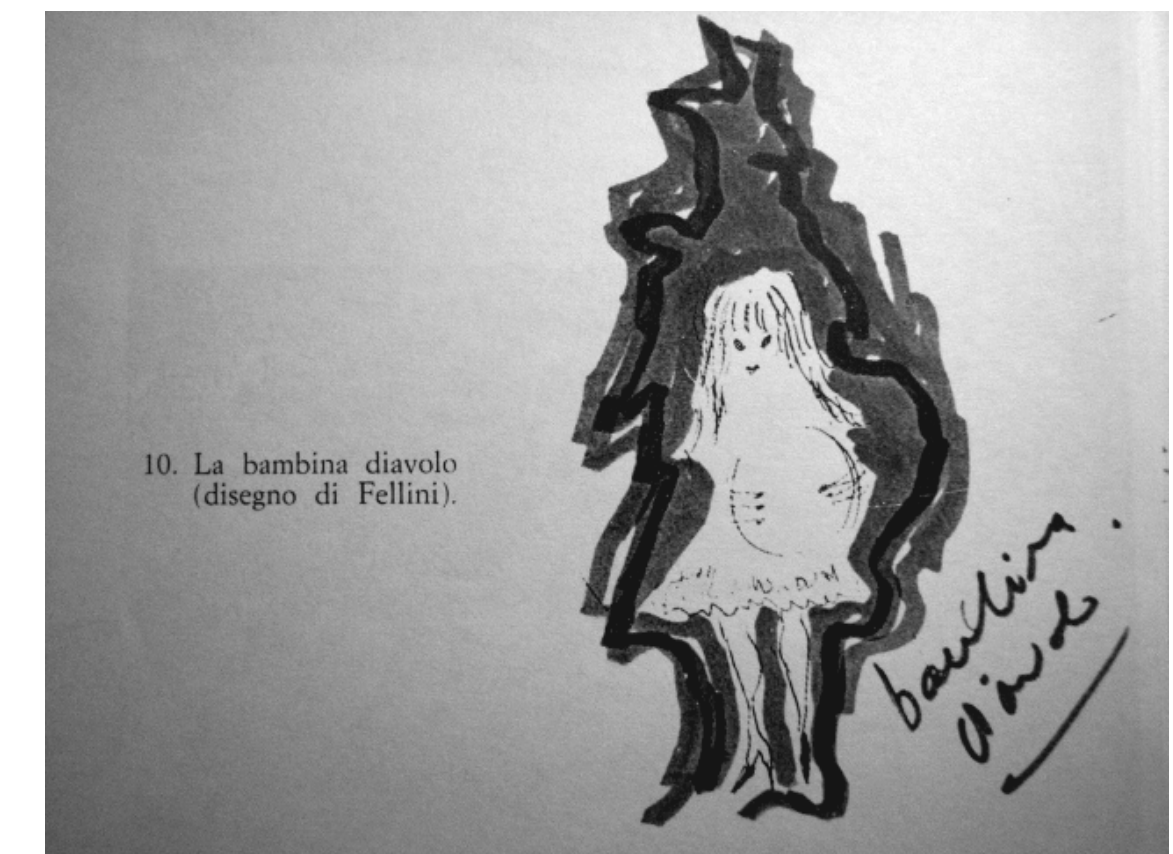

Imagem 124 Desenho feito por Fellini para personagem da Menina-Diabo (SANTI, 2004, p. 92)

O figurino da Menina-Diabo é sempre o mesmo, enfatizando um certo caráter de entidade mítica. Sua maquiagem é toda branca, não há realce nos olhos nem nos lábios. O branco prevalece em toda a pele e os olhos são claros. Ela usa um vestido branco rendado na parte inferior, com mangas curtas e bufantes, como o de uma boneca, arrematados com meia calça de lã branca e sapatinhos pretos de fivela, exatamente como no desenho feito, anteriormente ao filme, por Fellini.

Neste personagem, os efeitos de contraste e ambigüidade, foram os mais empregados para sua composição. Enquanto mais comumente vemos o branco ser associado a aspectos de pureza, inocência e bondade, aqui o vemos associado a uma falsa pureza, justamente para dissimular o caráter sombrio da menina e para tornar ainda mais aterrorizante sua maldade, pela suspeita que nos causa sua fisionomia contraditória, ambígua, ou o fato de estar sempre deslocada nos ambientes em que aparece e de só ser vista pelo protagonista, mesmo estando em meio a outras pessoas. O branco também é associado a um silêncio fértil, a partir do qual podem nascer novas possibilidades (KANDINSKI, 2000, p. 95 e 96). Este poderia ser outro disfarce, a oferta de um possível recomeço, de uma nova chance, que não será dada. 

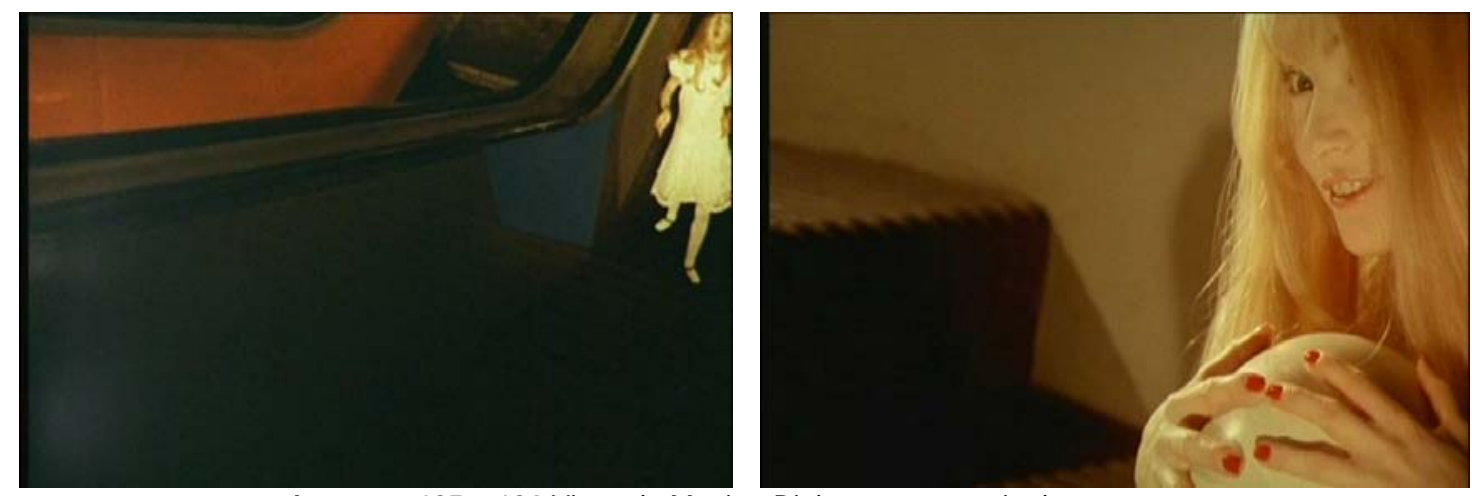

Imagens 125 e 126 Visão da Menina-Diabo na sequência do aeroporto

O branco também possui algo de fantasmagórico e essa aparição constante da menina pode remeter-nos à aparição constante do fantasma que persegue Hamlet, na tragédia de Shakespeare. Talvez também por essa relação de identificação com o personagem shakespeareano, Dammit desempenhasse tão bem o papel.
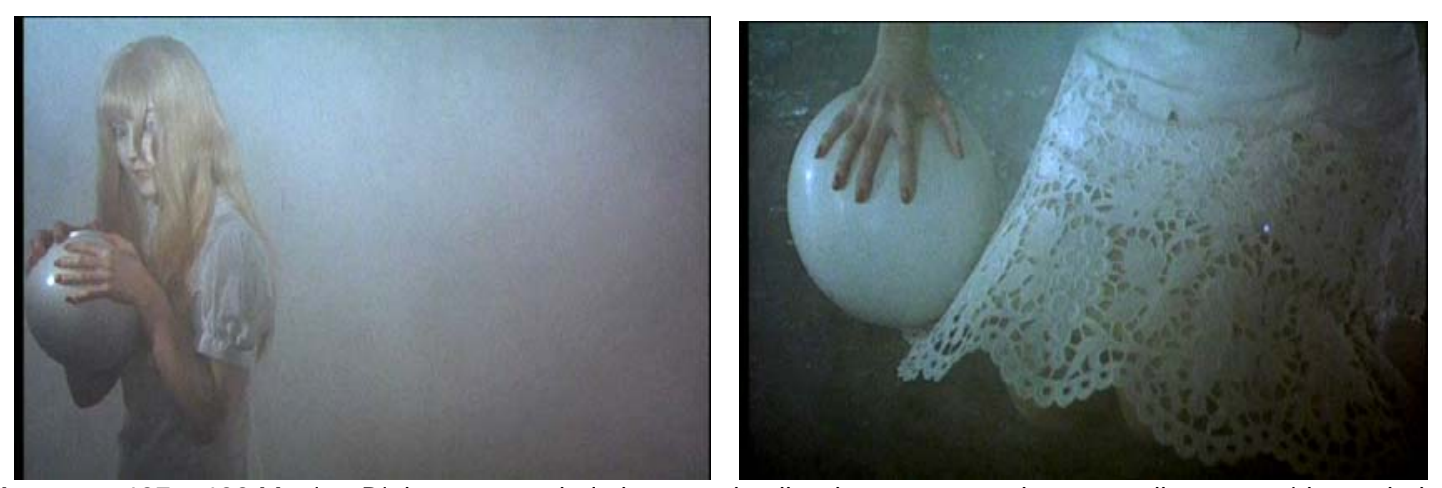

Imagens 127 e 128 Menina-Diabo com sua bola branca, detalhe de sua mão, unhas vermelhas e vestido rendado

O traje de tipo infantil, a renda do avental, o corte de cabelo com uma franjinha também foram escolhidos na chave do contraste. Todos estes elementos lembrariam ternura, mas somados à feição diabólica da menina acrescentam um caráter inesperado às atitudes dela, não se sabe mais o que esperar e o suspense se torna torturante e amedrontador.

Além da fisionomia e do gestual facial da menina ser inquietante, ela fita a câmera olhando diretamente para o espectador, o que faz com que nos sintamos exatamente como no lugar de Dammit. Seu olhar incita uma resposta, é como um jogo, que se completa com o arremesso da bola, igualmente branca, pois faz parte de seus artifícios e a cor serve para identificá-la. Pode se tratar também de um jogo de sedução, instigado pelo olhar lançado por ela e nada próprio da idade, uma sedução perigosa como um veneno doce. Sedução que se revela também na cor usada nas unhas da atriz, que mesmo curtinhas 
como as de uma criança, exibem um vermelho que fixa nosso olhar e causa espanto. É a única cor usada pela Menina-Diabo, ela salta no meio do branco e fatalmente está associada a (garras sujas de) sangue, morte, senão a perigo.

\section{Cenários}

\section{O AEROPORTO}

O filme se inicia com o pouso do avião de Dammit e o primeiro ambiente que se vê é o do aeroporto, um cenário predominantemente amarelo e laranja. Uma luz crepuscular invade a cena, tingindo inclusive os personagens. Há grandes janelas como grandes paredes de vidro, o que justificaria a maciça entrada de luz. Há um abuso no recurso usado de maneira anti-naturalista, inclusive em angulações diferenciadas, tendo em vista o efeito dramático e gerando uma sensação de irrealidade, de pesadelo.
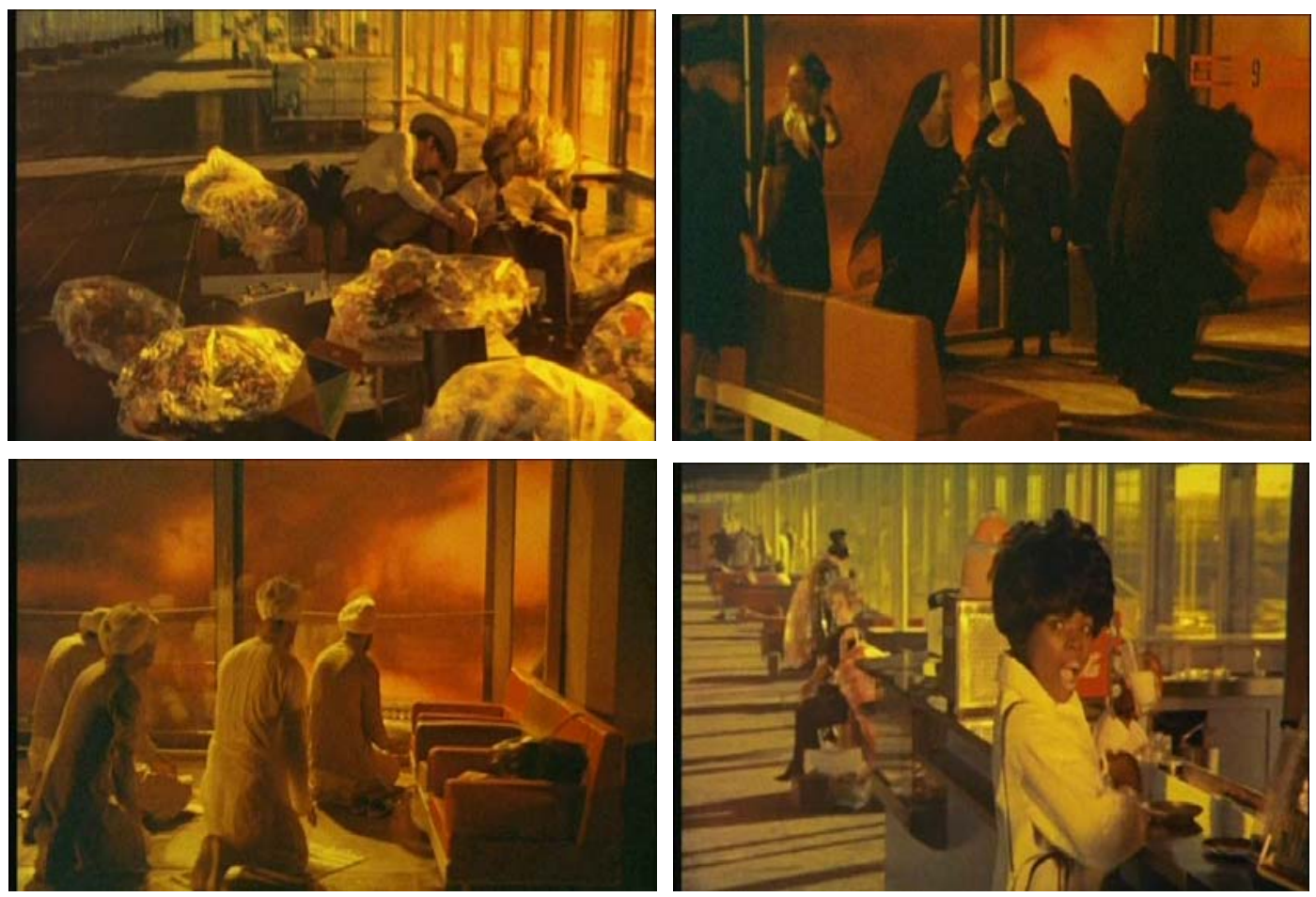

Imagens 129, 130, 131 e 132 Núcleos temáticos no aeroporto quando Toby Dammit chega em Roma

Esta iluminação forte cria sombras mais duras, resultando numa fotografia bem contrastada. Fortalecendo o contraste, os figurinos foram compostos usando predominantemente preto com detalhes em branco roupas de Dammit, do padre e da guia italiana, o que faz com que os personagens se destaquem nesse fundo um tanto uniforme. 
Paralelamente, o restante dos figurinos, que não são em preto e branco, puxam para os tons quentes, variando tons de marrom e do próprio laranja - a moça que fica junto aos fotógrafos usa roupa inteira laranja, os dois diretores usam composições de terno e camisa, bege e marrom, que também eram cores da cartela de cores da moda da época.
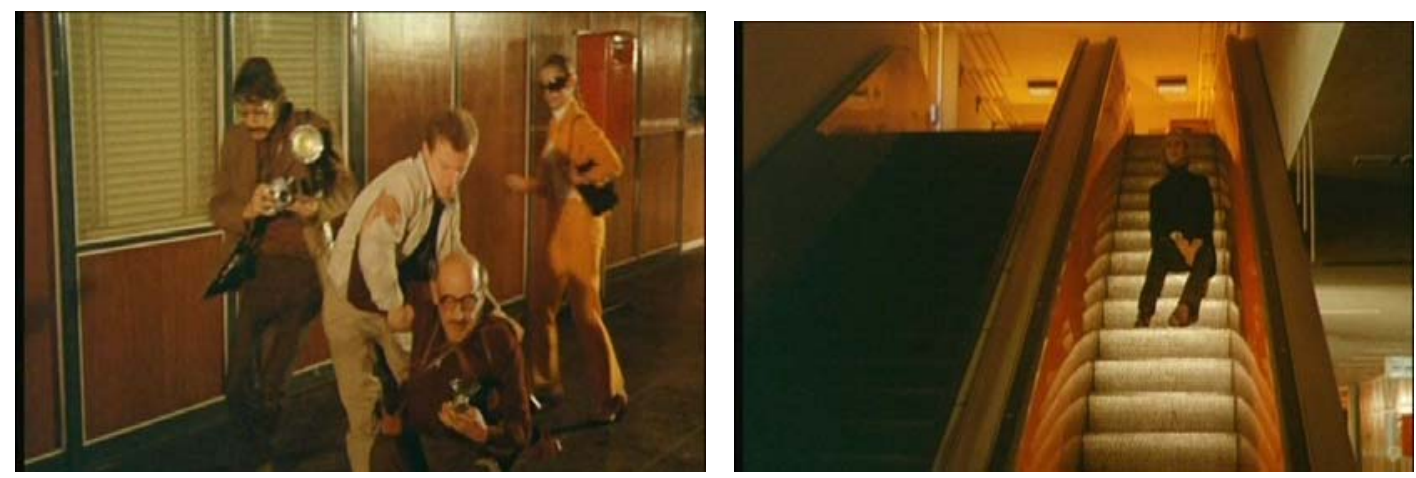

Imagens 133 e 134 Fotógrafos registram a chegada de Dammit que os empurra e senta-se na escada rolante

O próprio material de que são feitas algumas paredes - madeira marrom avermelhado - ou a parte interna das escadas rolantes - uma fórmica laranja escuro - também ajuda a intensificar a cor laranja no ambiente e suas derivações quentes. Trata-se de uma cor que coloca menos em estado de alerta do que o vermelho, mas não deixa de fazer uma colaboração neste sentido, ao mesmo tempo em que também causa certa irritação por estar sendo usada em demasia. Tal cor extravasa como uma irradiação de calor, contagia com sua porção de amarelo, também responsável pelo caráter excêntrico (KANDINSKI, 2000, p.90). De um modo ou de outro, traz à tona não apenas os estados de ânimo do personagem ao chegar a Roma, como sua impressão do lugar, a confusão, a luminosidade excessiva (que ele detesta), o "calor italiano" dos que o recebem.

Multicolorido, vemos apenas um painel grande, em formato de máscara preenchida por uma bricolagem de cores e flores de crochet, bem ao gosto da época. Um caráter multicolorido que parece identificar para Fellini os astros pop, pois ele só torna a reincidir nos músicos que encontramos na rua e na banda de rock que toca na festa. Assim que esta máscara é enquadrada, surge Toby Dammit pela primeira vez: ele invade o enquadramento se esquivando dos flashs das câmeras fotográficas, incomodado. Talvez a máscara venha lembrar que se trata, antes de mais nada, de uma pessoa comum por trás da imagem idealizada do astro. 


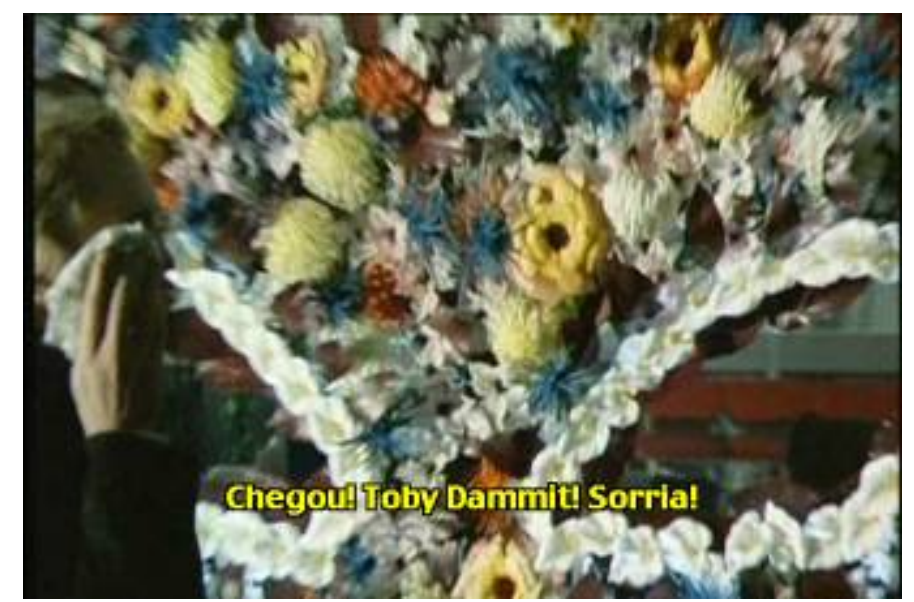

Imagem 135 Primeiro plano em que se vê Toby Dammit no filme - sobre fundo multicolorido

Acompanhando esta leitura, vemos no aeroporto, à medida que avançamos (ponto de vista de Dammit chegando a Roma) pessoas estranhamente arranjadas - algumas usam máscaras de papel xerocopiado com a fisionomia de outra pessoa, às vezes uma pessoa inteira em papel xerocopiado encontra-se sentada numa poltrona. $O$ fato de ser xerox em preto e branco, remete à idéia de pessoas sem cores autênticas, não apenas comuns, mas cópias ordinárias umas das outras. Remete também à idéia da desvalorização da identidade e do caráter único, divino do ser humano.

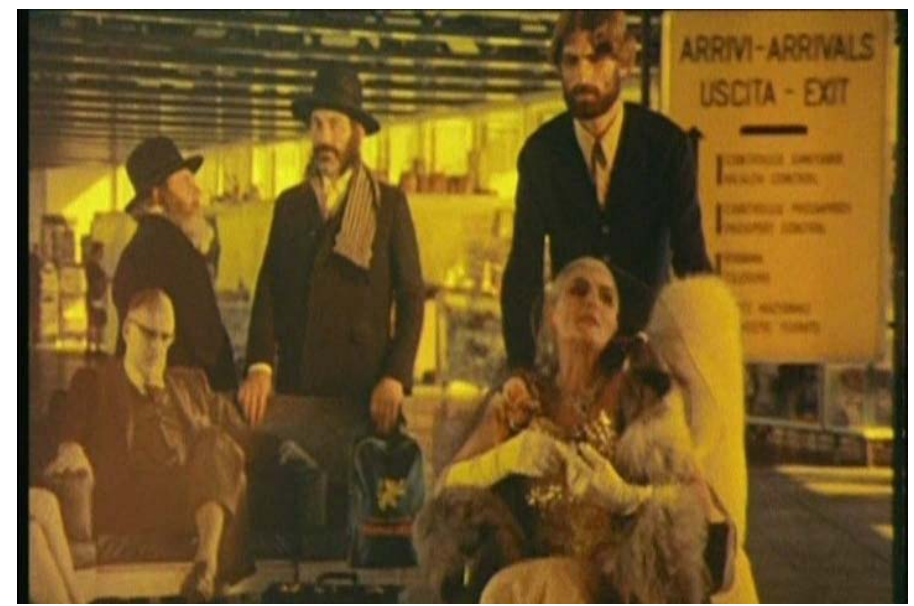

Imagem 136 Pessoas inteiras de xerox são vistas no aeroporto

\section{AS RUAS DE ROMA}

Na cena seguinte, que se passa nas ruas, há um prolongamento desta cor amarelo-laranja uma vez que estamos num tempo contínuo e em que também não houve mudanças no ponto de vista do protagonista. O clima é de confusão, com temperaturas altíssimas, um inferno contemporâneo. Os ânimos dos que dirigem no trânsito caótico representado pedem tom inflamado - 
muitos brigam física ou verbalmente, outros tentam consertar motores fundidos de carros no meio do tráfego, de onde sai muita fumaça. Além disso, há elementos colocados em cena como postas de carne penduradas num caminhão aberto, um cortejo com a imagem de Nossa Senhora cercada de velas acesas (fogo / luminosidade que queima).

Aquele fluxo intenso de carros, todos ao mesmo tempo, nos dá a impressão de ser impossível desviar o curso, de Dammit ter tomado um caminho irreversível, um pouco como a sensação descrita por ele antes do pouso do avião, como se já tivesse sido capturado pela trama de uma rede invisível de onde não pudesse mais escapar. (Talvez como resultado de forças ocultas exercidas pela Menina-Diabo, em decorrência do possível pacto feito com Dammit)

O pressentimento de que algo de terrível iria acontecer é acrescido pela aparição de uma cigana vestida de vermelho, cor que poderia alertar para o perigo eminente, principalmente se analisada em conjunto com o olhar pesaroso que ela lança para Dammit após ter dado uma rápida olhada nas linhas da mão do ator, sem ter coragem de lhe dizer nada.
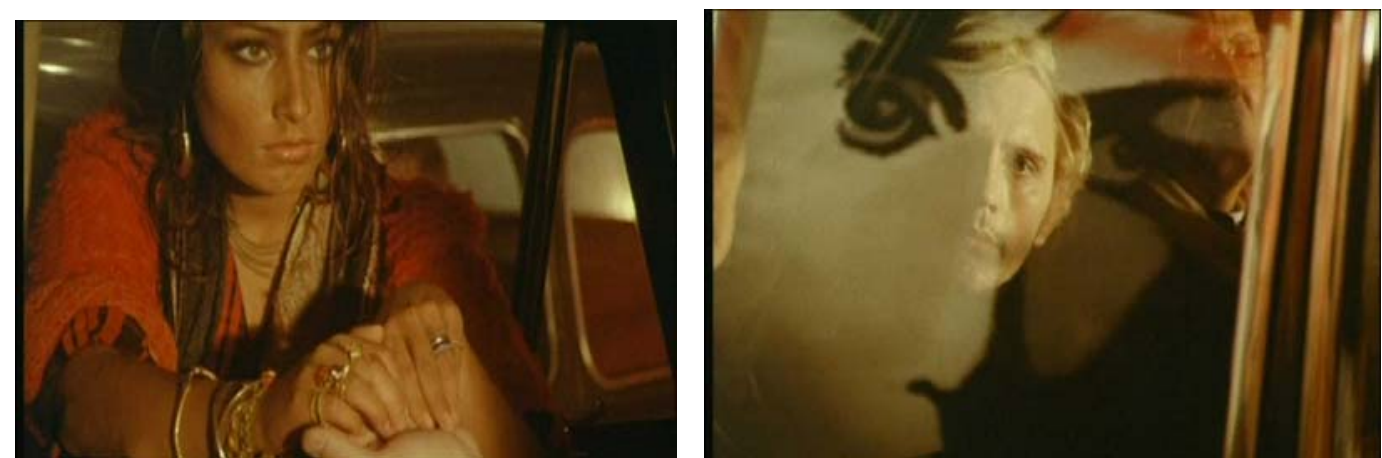

Imagens 137 e 138 4Cigana cala a sorte de Dammit e ele a olha pelo vidro do carro, sobre o qual reflexo feminino antecipa a aparição da misteriosa mulher de preto da festa da premiação

E um momento antes da aparição da cigana, temos outra antecipação, a da mulher misteriosa que fala com Dammit na festa da premiação. Vemos o desenho de seu rosto com os grandes olhos pretos refletido no vidro da janela de Dammit quando o carro passa em frente a um muro com grafittis.

A seqüência é finalizada com a imagem do monumental Coliseu, outro ícone italiano de peso, cercado de carros, num trânsito aprisionado, sob um céu que já está quase escurecendo, numa gradação de laranja para magenta, 
o que nos faz sentir a temperatura aos poucos ir baixando, como uma brasa que se apaga com o frio do negro-azulado da noite.

\section{O ESTÚDIO DE TELEVISÃo}

A partir de então, os cenários tornam-se menos coloridos e, pouco a pouco mais escuros. A próxima seqüência se passa num estúdio de televisão, onde predomina uma fotografia "lavada", de iluminação difusa, gerando imagens mais claras com sombras suavizadas, assim como as imagens transmitidas pelos aparelhos de TV. As cores usadas são tons de cinza até o branco e matizes de azuis e verdes acinzentados.
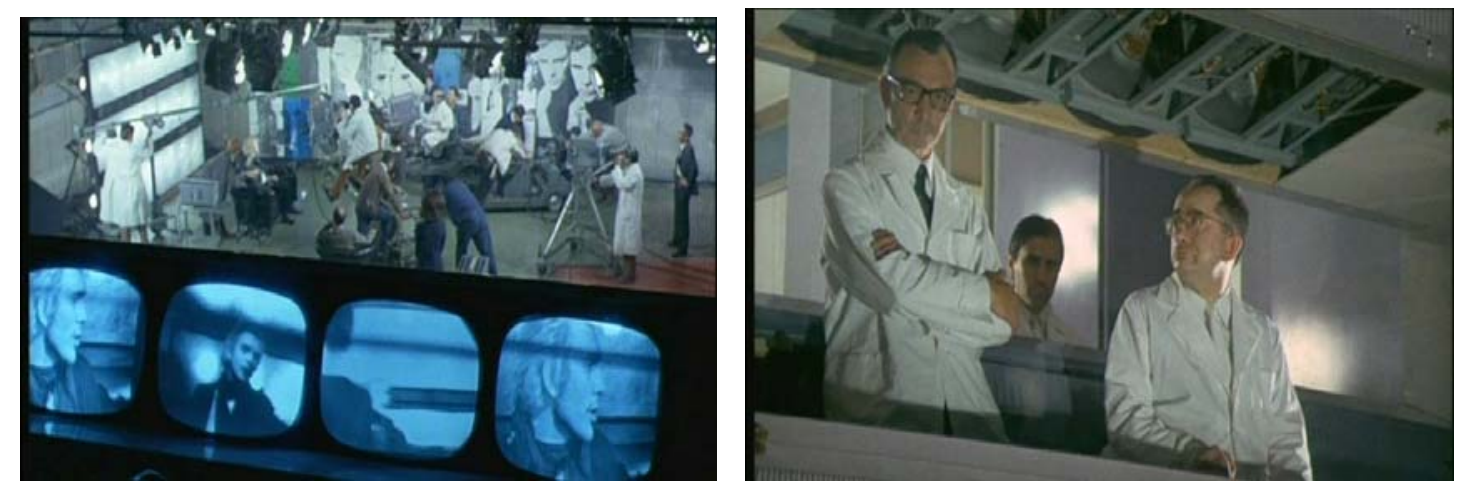

Imagem 139 e 140 Estúdio de TV onde Toby Dammit é entrevistado por vários jornalistas

Os tons frios utilizados se adequam à frieza das pessoas que ali trabalham. Os tons de cinza ajudam a camuflar as pessoas entre as máquinas, câmeras e gruas que parecem mexer-se sozinhas, lado a lado com os jornalistas (como uma extensão dos mesmos), cercando o entrevistado por todos os lados. Ao mesmo tempo, os tons de cinza usados nesses figurinos acrescentam opacidade, parecem disfarçar alguma sujeira e ainda emprestar uma falsa distinção. 


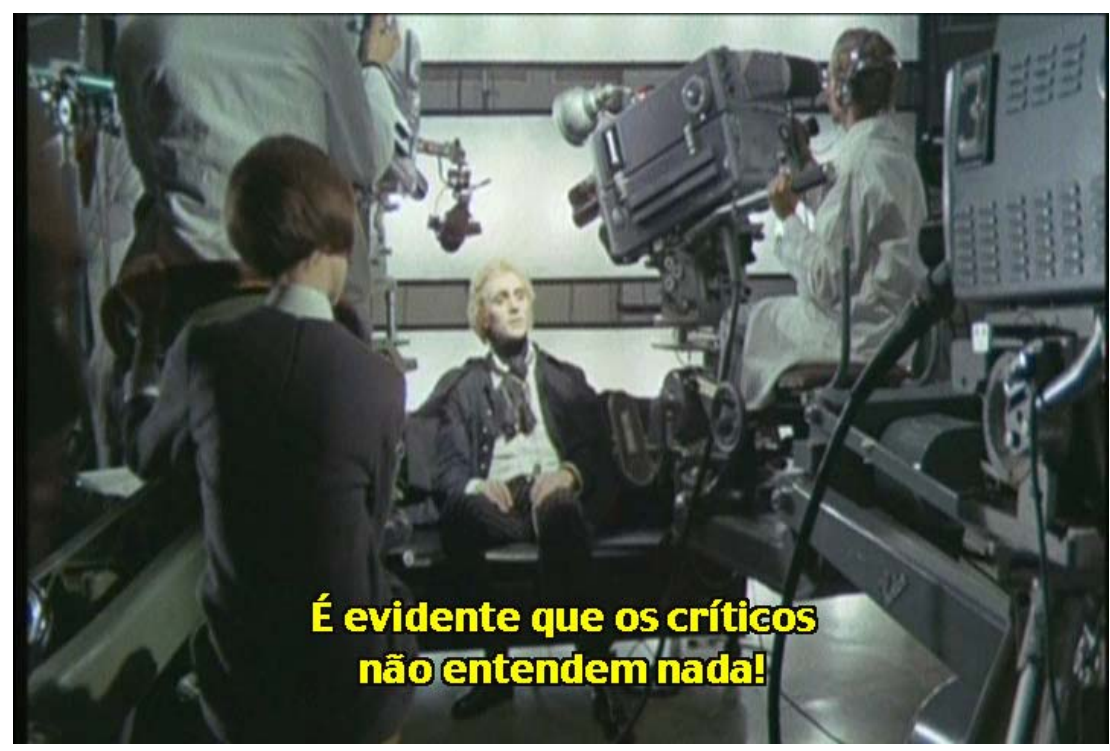

Imagem 141 Toby Dammit em frente às câmeras

Os operadores de câmera e de imagens na switcher do programa usam, como já apontamos, jaleco branco, o que nos faz associá-los a cientistas em um laboratório, até pela posição em que estão no cenário; observando a cena lá de cima, fora do alcance dos que estão sendo analisados por eles. Considerando que eles é que definem sob qual ponto de vista o entrevistado será visto, em que momentos e em que medida será aplaudido pela "máquina de aplausos", temos uma atitude manipuladora e "coisificante" para quem está sendo entrevistado e para quem assistirá a entrevista, e não uma atitude imparcial. É cerceante.

O branco que mais comumente é associado à limpeza e à inocência, aqui vem associado ao contrário, com um disfarce. Ele reincide da mesma maneira na figura da Menina-Diabo, já abordada anteriormente. O "mal" disfarçado de branco, de seriedade inquestionável como se vê aqui, se torna mais cruel.

\section{A FESTA}

O cenário seguinte é o da festa do "Oscar Italiano", que se passa num ambiente absolutamente sinistro. Parece-se com uma caverna, um ambiente sujo, onde se criou uma decoração para a festa com mesas e cadeiras, com arranjos de velas compostos com uma forma e coloração que permite às chamas perecerem flutuar no ar como por mistério. Há uma névoa sobrenatural e fantasmagórica por toda parte, dificultando a visibilidade, como se algo 
precisasse ser escondido (a sujeira, a verdadeira expressão das pessoas...), e um lago artificial no meio do espaço. No palco, três mulheres estáticas estão vestidas como colunas greco-romanas, exaltando a cultura clássica italiana e talvez explicitando que o "espetáculo social" esteja sendo sustentado por estruturas já por demais gastas, mas ainda ostentadas como signos de nobreza e poder.

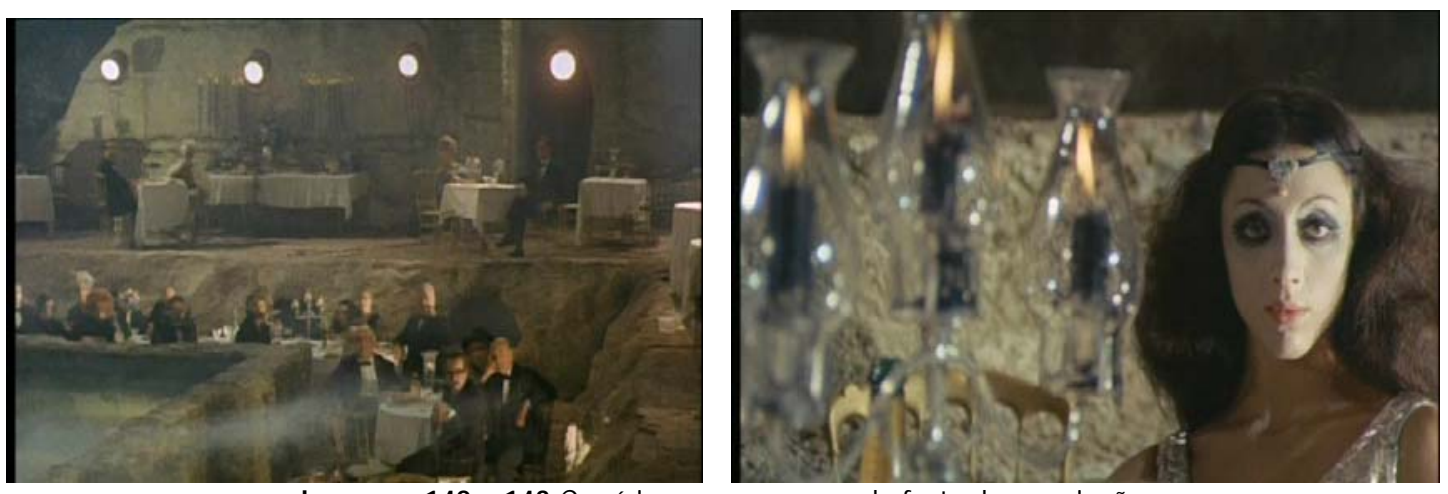

Imagens 142 e 143 Cenário e personagens da festa da premiação

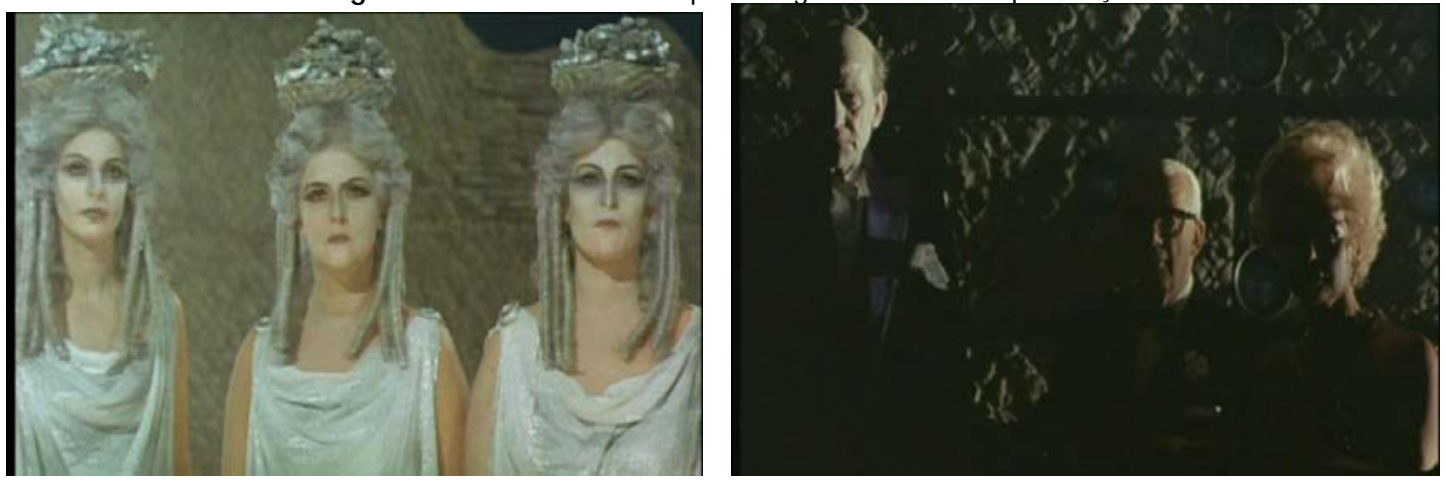

Imagens 144 e 145 Personagens da festa da premiação

Os figurinos são predominantemente pretos com detalhes em branco e prata, evocando sobriedade e elegância. Quando há cor, usa-se tons de azul e violeta. De modo geral, há no conjunto um tom de mistério sombrio e de tristeza que contrasta com o fato da ocasião ser uma festa.
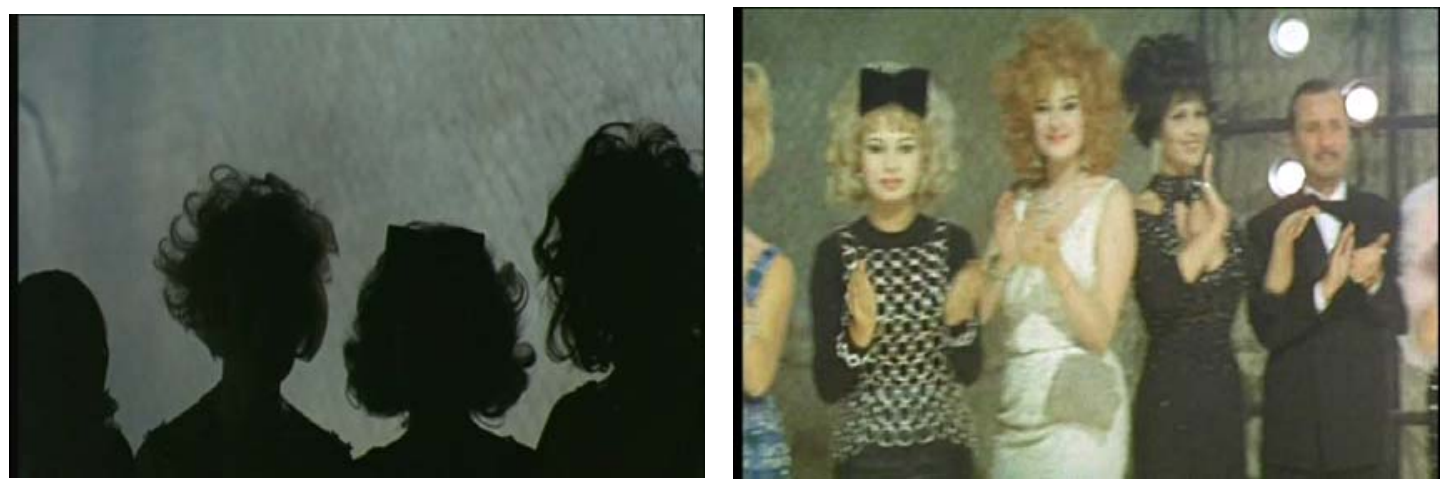

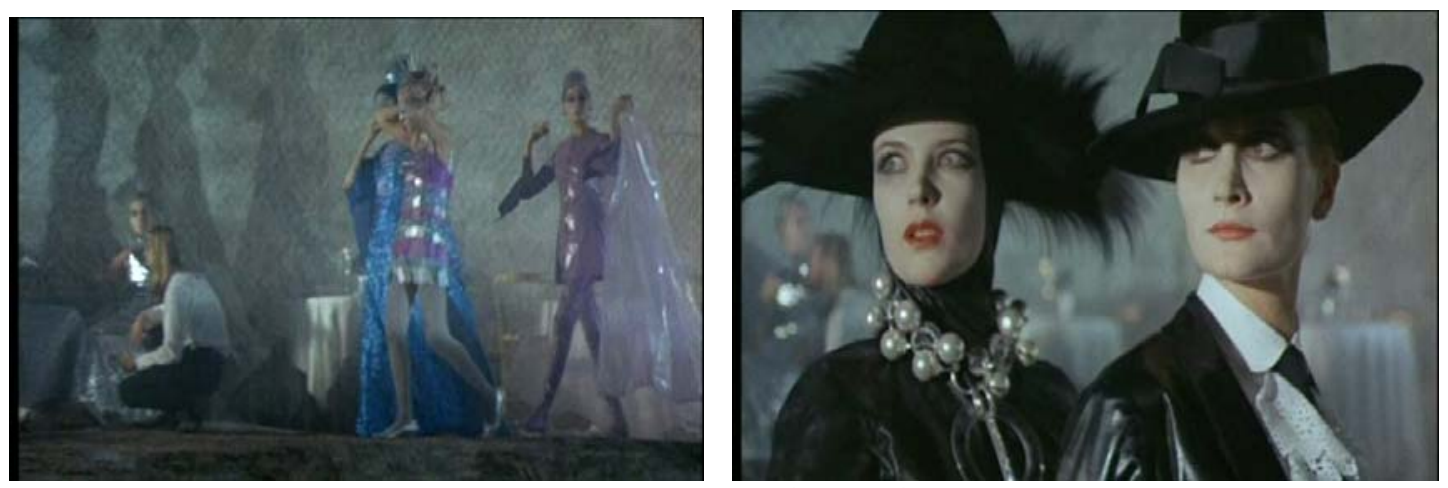

Imagens 146, 147, 148 e 149 Personagens da festa da premiação - cores frias

Os únicos figurinos mais coloridos são os dos músicos, que por isso se destacam da situação, talvez por estarem ligados a um elemento vital que é a música, à contra-cultura, à imagem de astros pop e por não se ligarem aos outros personagens da festa.

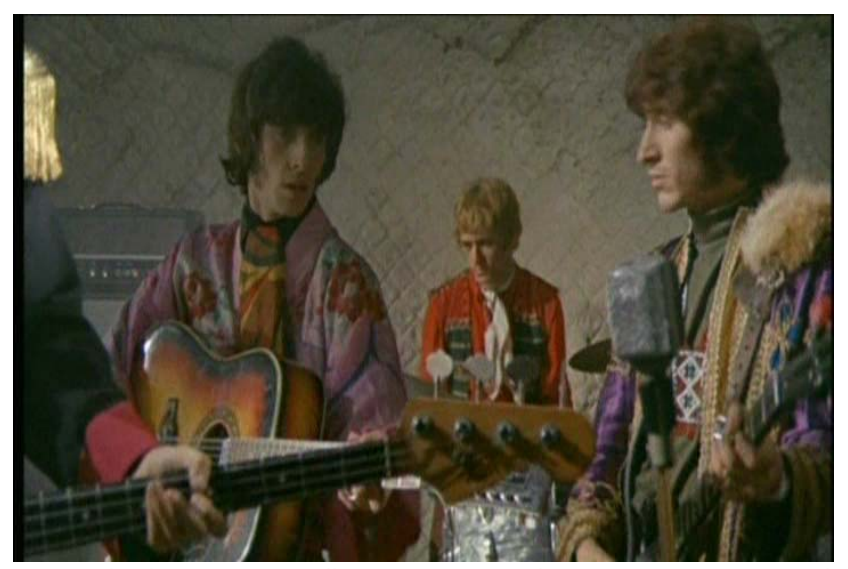

Imagem 150 Banda da festa, semelhança com Beatles Sgt. Peppers - núcleo colorido

A personagem talvez mais enigmática do filme pertence a esta seqüência. É a mulher misteriosa que vem falar com Dammit no momento em que ele está desacordado na cadeira. Ela se veste distintamente de preto, com casaco de textura macia, é lindíssima, tem olhos grandes e amorosos, diz palavras de lealdade e compaixão. Neste momento, uma música romântica em inglês, interpretada por Ray Charles, ressoa comunicando diretamente ao coração do ator inglês, que não parece saber se aquilo faz ou não parte de um sonho. Estranhamente, a bondade aqui vem vestida de negro, talvez para representar distinção, ou para lembrar o conforto de uma noite escura em que se pode finalmente dormir e descansar das luzes e do barulho sem fim. 


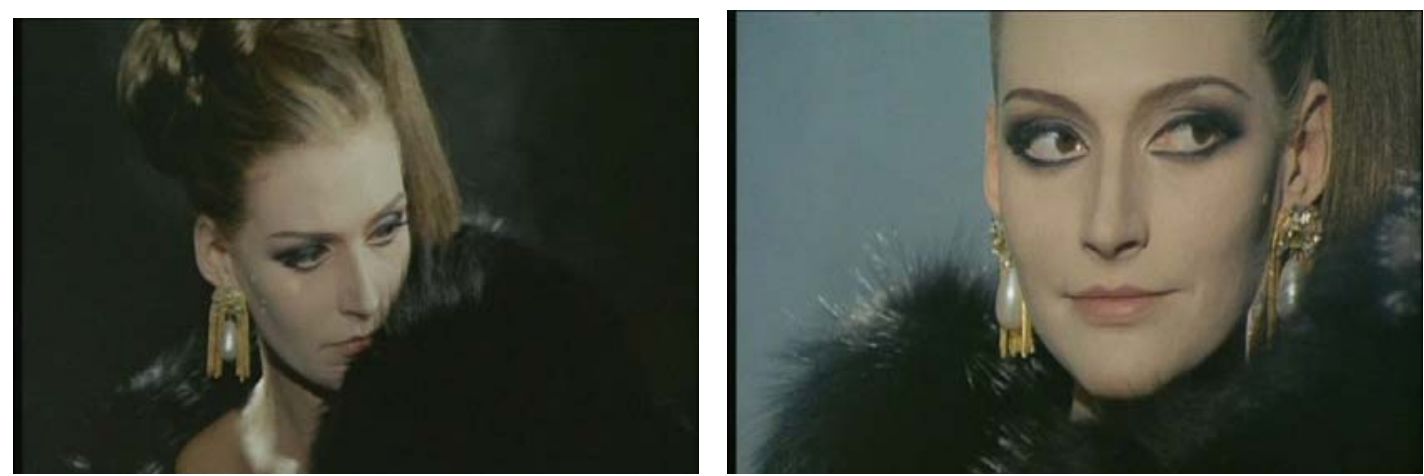

Imagem 151 e 152 Misteriosa mulher de preto que acolhe Dammit - personagem mais humano da trama

\section{A CIDADE}

Deste ambiente, Dammit passa à cidade, durante sua vã tentativa de fuga em direção a Roma em sua Ferrari cor de laranja (cor que combina com a vontade do personagem de extravasar, de não se acomodar no lugar onde está). Nas ruas, vêem-se pessoas estáticas como bonecos em frente a restaurantes representativos da cultura italiana, em outros momentos, vêem-se bonecos mesmo, que ele em uma das vezes, volta num acesso de fúria e atropela. Há ovelhas de mentira misturadas a outras de verdade (num rebanho que pode ser metáfora da sociedade, onde uns são verdadeiros e outros não, ou pode ser símbolo da inocência, umas de verdade e outras não, ou ainda, remeter à imagem emblemática de sacrifício, sempre associada a ovelhas) e um pastor que dorme (pode estar se referindo à Igreja, que apenas finge cuidar do seu "rebanho"). Ao encontrar um transeunte, pergunta como sair, mas o velho italiano está bêbado e lhe devolve apenas um olhar fixo e satírico.

Assim como no aeroporto de Roma pôde-se ver algumas pessoas usando máscaras feitas em xerox preto e branco no lugar do rosto, na cidade da qual Dammit não consegue sair, vê-se também uma grande estátua de xerox no meio da praça, dois cachorros também em xerox e, um pouco antes de encontrar novamente a Menina-Diabo, uma das pessoas que surgem para alertá-lo sobre o rompimento da ponte também usa uma máscara de feição xerocopiada.

Se no momento anterior, Dammit encontra-se espremido em vias estreitas, cercado por paredes muito próximas umas das outras, ou por estradas igualmente estreitas, com curvas fechadas, agora ele depara-se com um espaço descampado em linha reta. Há um horizonte largo, embora pouco 
consiga ser visto com a baixa luminosidade e a forte neblina. Há um respiro e uma decisão a tomar - seguir em frente ou voltar e tentar achar o retorno - é quase uma encruzilhada. Exatamente quando surge a Menina-Diabo do outro lado da ponte partida instigando-o a saltar, numa atitude análoga à do velho no conto, instigando-o a saltar o torniquete. $\mathrm{E}$ da mesma forma como acontece no texto, Dammit consegue realizar o feito, mas acaba decapitado e sua cabeça fica em posse da menina - o diabo.

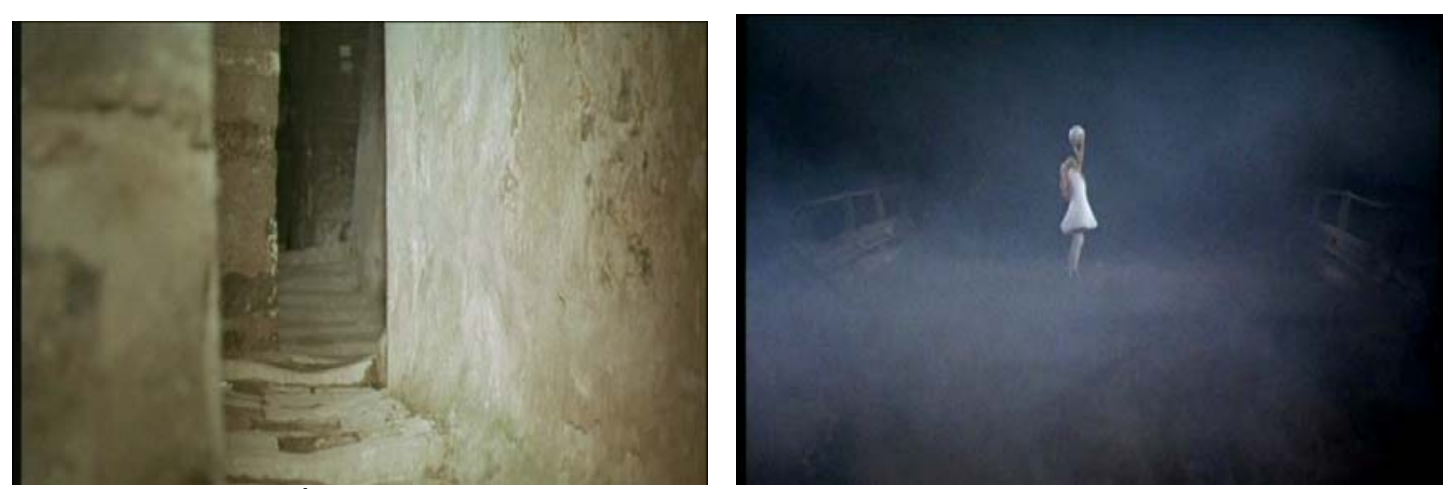

Imagem 153 e 154 À esquerda, vielas da "cidade-cenário" e à direita, Menina-Diabo do outro lado da ponte 
Capítulo 3

Desdobramentos do Cinema de Fellini Considerações Finais 


\section{Desdobramentos do Cinema de Fellini}

Em quatro décadas de criação, inventando e dirigindo seus filmes, num total de 24 películas, Fellini deixou para nós sua impressão do mundo, através de um olhar poético muito próprio sobre a alma humana. Em sua obra há de tudo: o cômico, o satírico, o ingênuo, o lírico e o passional.

Sua maneira de contar histórias, portanto, além da escolha de quais histórias contar, é pessoal e especial. Seu comprometimento com a plasticidade do filme se manteve desde o início de sua carreira e só se sofisticou com o passar dos anos.

Se Fellini é um mestre, há muito o que aprender com seu cinema. Com todo este legado artístico, é possível dizer que há herdeiros para o cinema de Fellini? A resposta é difícil de ser encontrada. Nenhum outro cineasta até esta data, em minha opinião, se aproxima de sua genialidade estética, de seu lirismo, de sua poesia.

Não faltam, no entanto, admiradores. Elenco a seguir alguns dos que considero ter algum parentesco com o cinema inaugurado por Fellini.

\section{TIM BURTON}

Podemos citar o trabalho do cineasta americano, Tim Burton ${ }^{36}$, que teve sua obra explorada em grande exposição no MoMA (Museum of Modern Art), em Nova lorque em 2009. A exposição tornou acessível ao público um material desconhecido por todos - maquetes, bonecos e desenhos, grandes ou pequenos, com todo o tipo de detalhamento, feito pelo cineasta para orientar seu processo criativo e o de seus colaboradores. As semelhanças envolvendo os processos criativos dos dois cineastas não são mera coincidência, Burton conhecia o processo criativo de Fellini.

\footnotetext{
${ }^{36}$ Timothy Walter Burton nasceu em 25 de agosto de 1958, na cidade de Burbank, em Los Angeles no estado da Califórnia.
} 


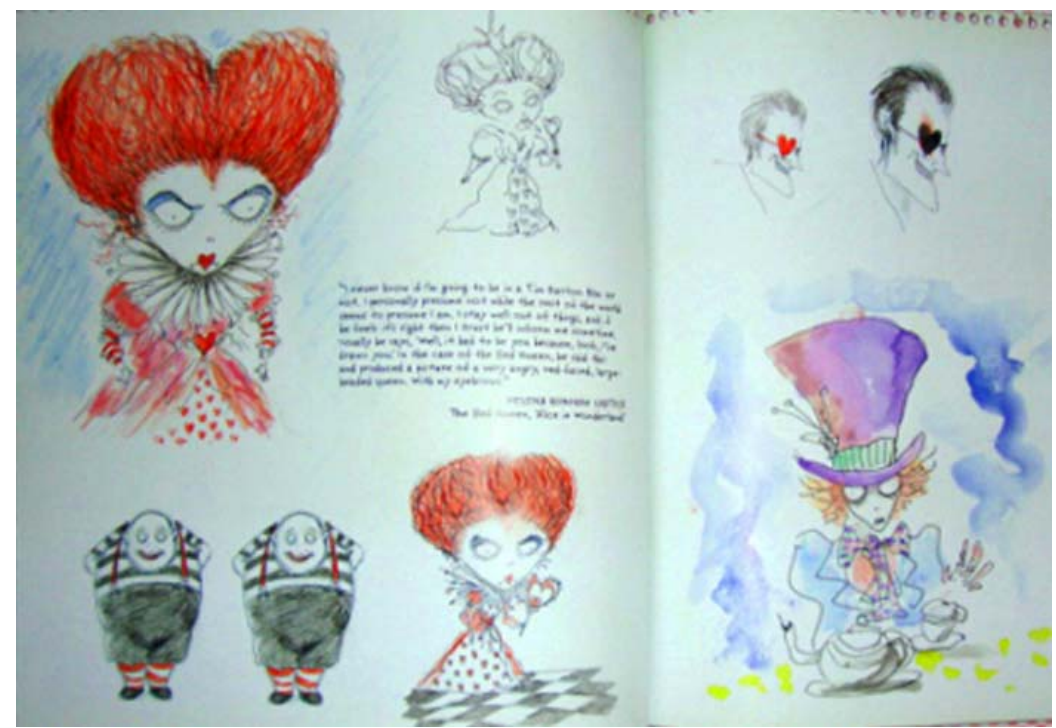

Imagem 1 - Desenhos feitos por Burton para os personagens, Rainha Vermelha, Tweedle-Dee e Tweedle-Dum e 0 Chapeleiro Maluco, de Alice no País das Maravilhas
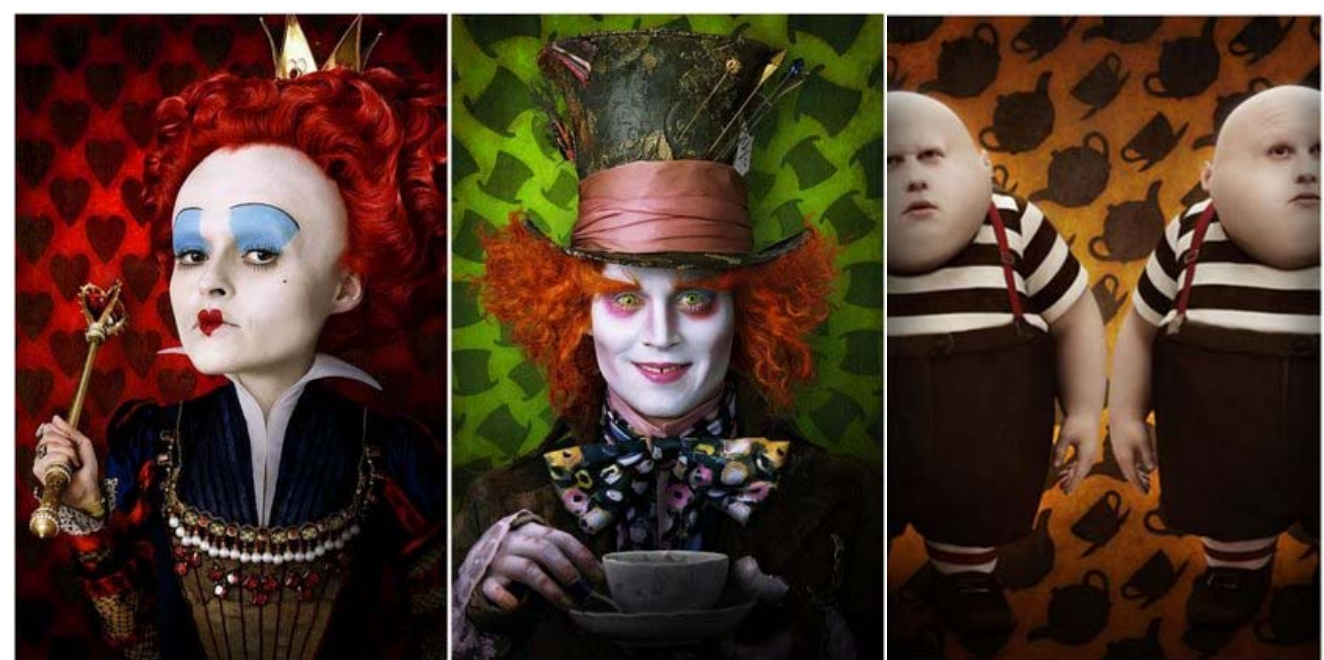

Imagem 2, 3, 4 Os atores Helena Bonham Carter, Johnny Depp e Matt Lucas, como a Rainha Vermelha, 0 Chapeleiro Maluco e Tweedle-Dee e Tweedle-Dum, respectivamente

A construção imagética para Burton é o ponto chave de seus filmes. Ele afirma que suas histórias são contadas por imagens e que a narrativa de seus filmes enquanto história narrada por palavras é muito menos impactante. No entanto, tem a maturidade de reconhecer que essa é uma maneira de fazer filmes e compara seu modo de contar com o de Fellini (BURTON, 2006, p.114). Sobre a importância da imagem em um filme, Burton afirma, retomando o cinema de Fellini:

The thing I liked about Fellini is that he created images that even if you didn't know what they meant literally, you felt something. It's not creating images to create images. And even thought I didn't fully understand a lot of what he was saying, I 
could feel a heart behind it. That's what his work meant to me, that things don't have to be literal, you don't have to understand everything. Even thought it may be an extreme image, something that is out of the realm of people's perception of reality, you feel something. It's that whole sort of unspoken thing that I find beautiful. That is the magic of movies. (BURTON, 2006, p. 51)

Assim, a prática do desenho é um importante ponto em comum entre os dois diretores. Ambos, antes de seguirem suas carreiras no cinema, trabalharam realizando desenhos. Tim Burton desenhava para a Disney e Fellini para revistas italianas. E eles se mantiveram, em virtude destes trabalhos e de suas referências, muito influenciados pelas artes plásticas e gráficas. O traço dos dois artistas é caricatural e cômico, possuem grande senso de humor e um gosto pelo mistério - o que em Fellini tende mais a uma visão espiritualista do mundo, enquanto em Burton, atinge um tom sombrio, muitas vezes sobrenatural. Este aspecto do trabalho de Burton também se reflete plasticamente quando notamos a influência do expressionismo em muitas de suas obras - nutria grande admiração pelo movimento.

Burton começou no cinema com o curta-metragem animado em stop motion, Vincent (nome dado em homenagem ao ator Vincent Price, de quem o diretor é fã). Sua carreira até hoje possui muitos trabalhos em animação, estando entre os mais bem feitos do gênero em todo o mundo. Talvez Burton continue filmando seus desenhos inclusive por poder ter assim maior controle sobre a estilização, a plasticidade de sua história e de seus personagens.

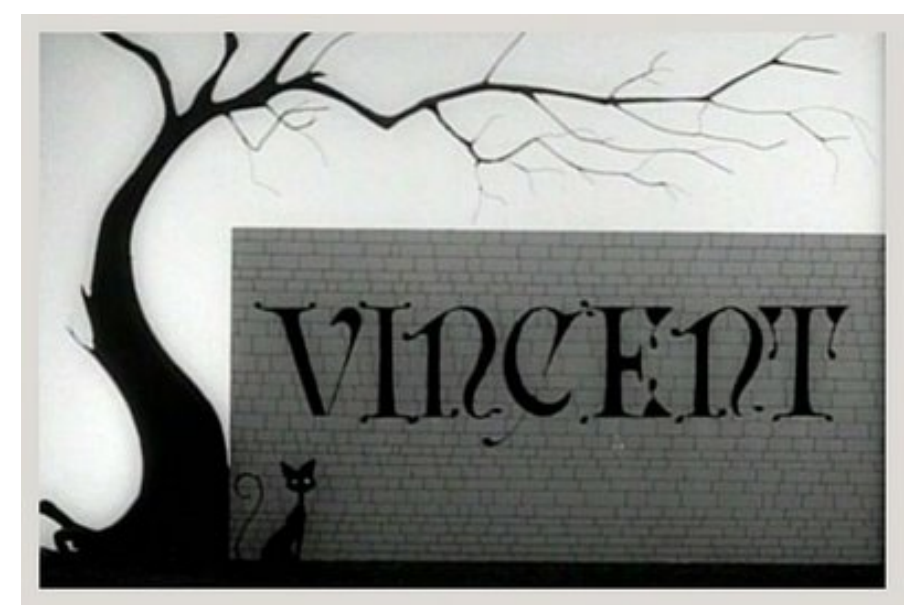

Imagem 5 - Cena de abertura do curta-metragem Vincent, primeiro na carreira de Burton 


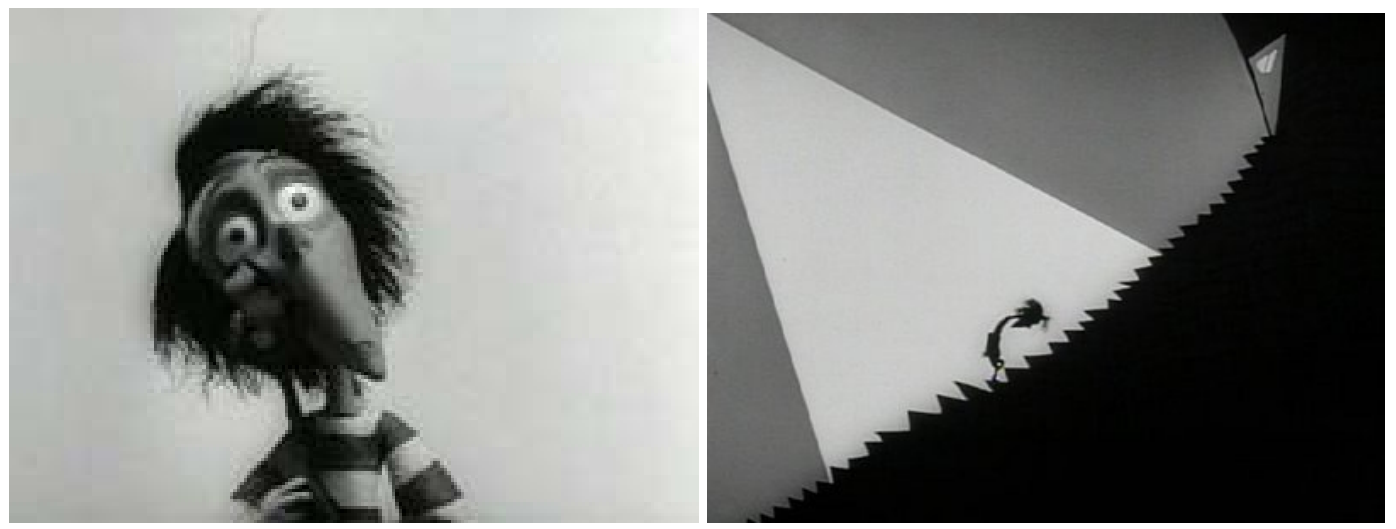

Imagem 6 e 7 Estilização do personagem e dos cenários lembra a estética expressionista alemã

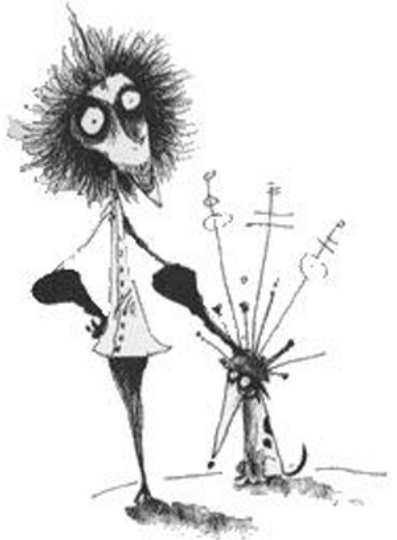

Imagem 8 Desenho feito por Burton para personagem Vincent e seu cachorro

Filmando com atores, Burton quase sempre conta com o ator Johnny Depp para interpretar seus protagonistas, como Fellini quase sempre contava com o ator Marcelo Mastroianni. As esposas dos dois cineastas, Helena Bonham Carter e Giulietta Masina, também são atrizes recorrentes nos filmes de cada um dos dois, parceiras na criação e no estilo.

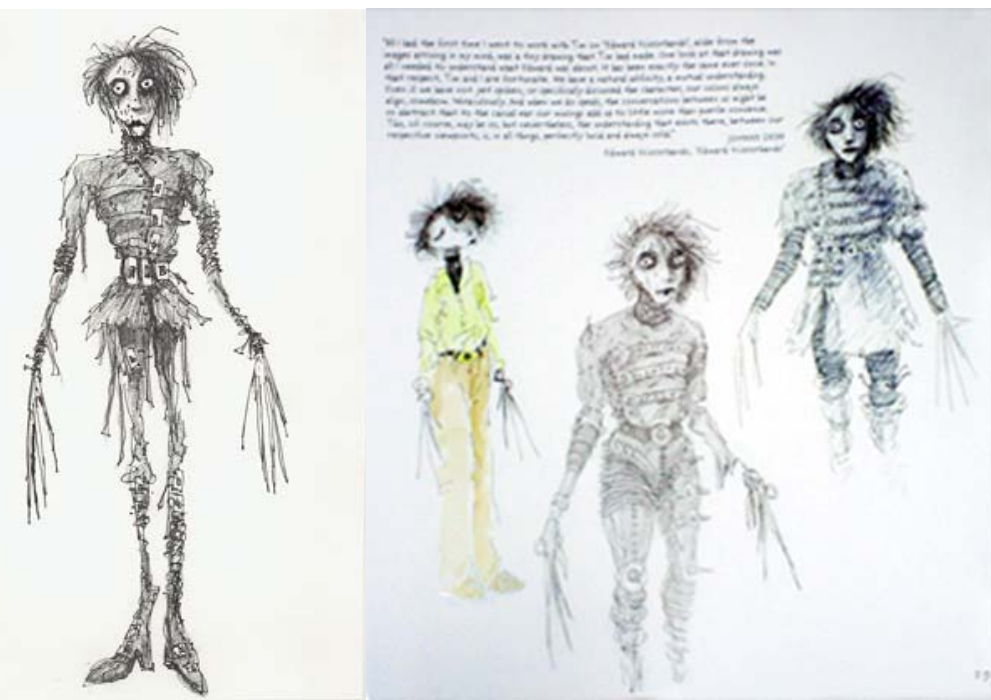

Imagens 9 e 10 Desenhos feitos por Burton para o personagem Edward do filme Edward Mãos de Tesoura 


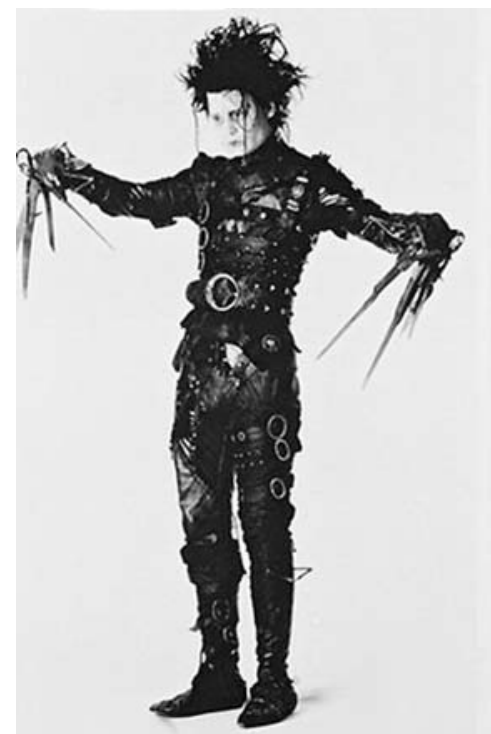

Imagem 110 ator Johnny Depp já caracterizado para o papel de Edward

Os cenários costumam ser fantásticos e grandiosos, tanto em um diretor como em outro. E Tim Burton chegou mesmo a contar com Dante Ferreti, um dos diretores de arte com que Fellini trabalhara, em seu filme Sweeney Todd: O barbeiro demoníaco da Rua Fleet, vencedor do Oscar de melhor direção de arte, em 2008.

Avaliando a obra de Tim Burton, pode-se dizer que seus filmes seguem um formato de fábula. Um bom exemplo disso está em Edward Mãos de Tesoura, filme em que o protagonista nos faz lembrar uma espécie de Pinóquio. O personagem fica "órfão de pai/cientista", antes de ganhar mãos de verdade, e precisa enfrentar o mundo das pessoas aprendendo a lidar com as diferenças entre ele e os demais, e os preconceitos que na maior parte das vezes acompanham esse tipo de situação. Temos a sensação de alguém deslocado de seu mundo, obrigado a conviver num outro que lhe é hostil, pela incompreensão.

Penso que talvez essa seja a sensação do cineasta em sua vida real, e que seu ato que realizar filmes, seja um pouco como o de Edward modelar os arbustos amorfos, transformando-os em curiosas figuras que enchem de vida e beleza todo o espaço. Acredito serem atitudes análogas à necessidade de tornar a vida mais expressiva, mais rica de sentido, à vontade de fazer das coisas muito mais do que elas aparentam ser. E demonstram também sua delicadeza com a criação. 


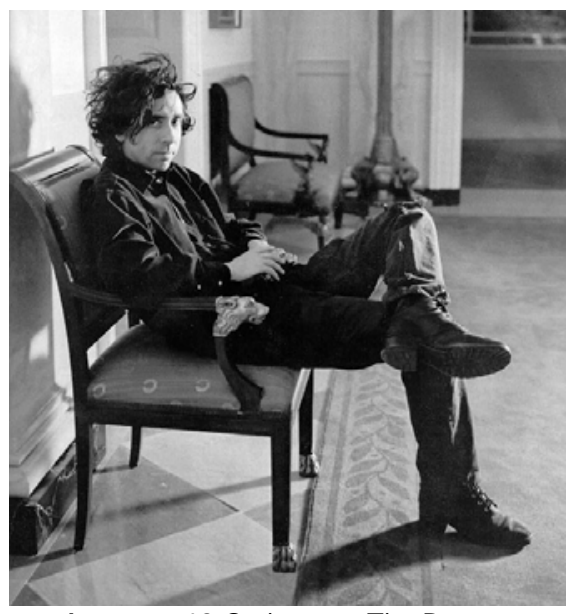

Imagem 120 cineasta Tim Burton

Há algo de alter ego na figura de Edward. Tanto quando pensamos na sua postura criativa, quanto quando pensamos no seu visual. Em Fellini encontro essa mesma motivação, de investir e revestir seus filmes de algo pessoal, autoral, projetar-se com sua visão de mundo em suas películas.
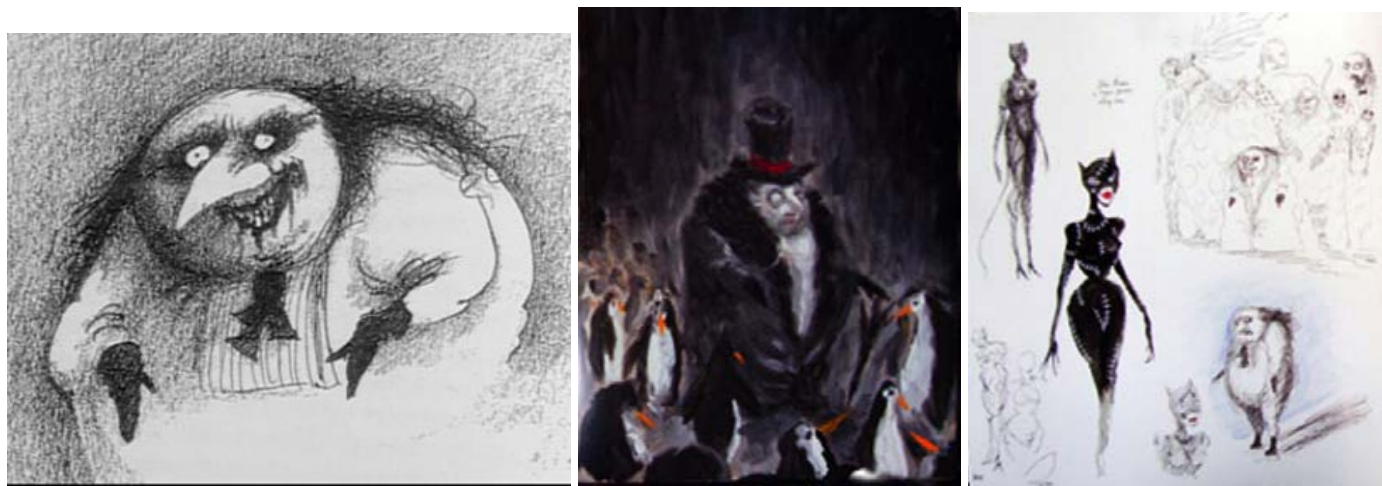

Imagens 13, 14 e 15 Desenhos feitos por Burton para os personagens Pingüim e Mulher Gato, do filme Batman Returns
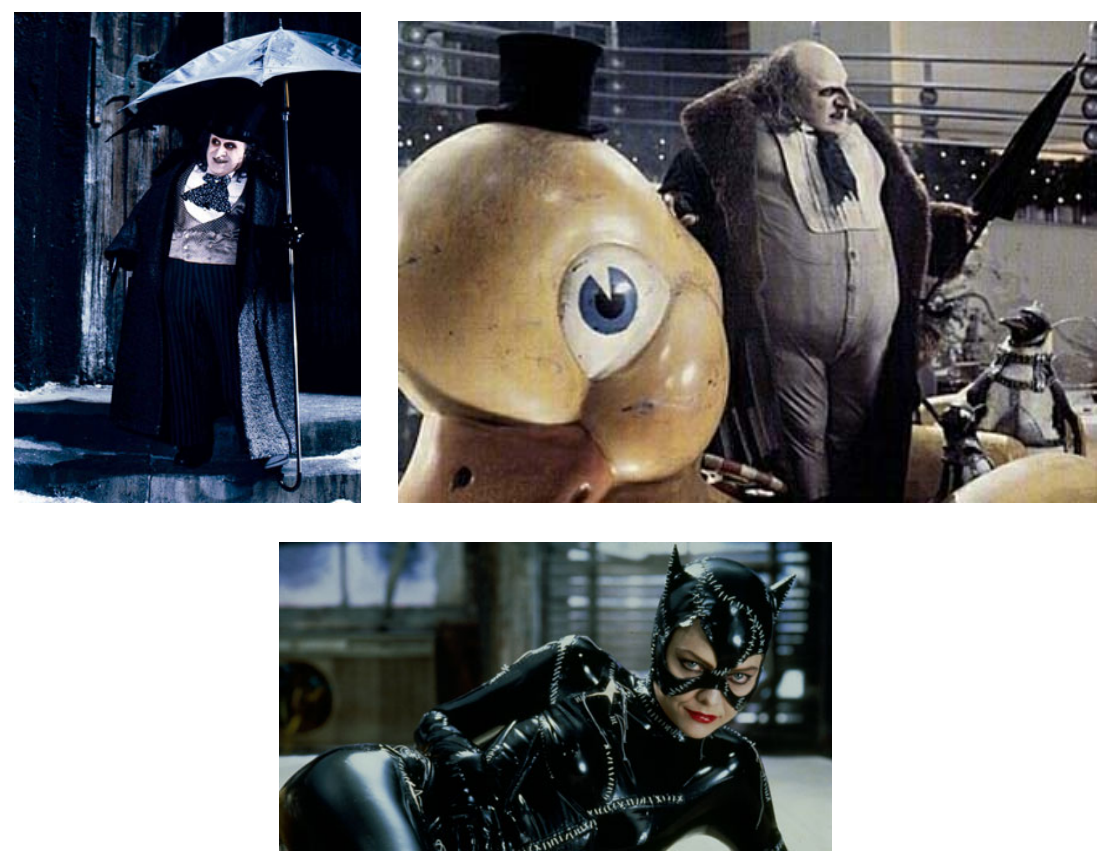

Imagens 16, 17 e 18 Danny DeVito como Pingüim e Michele Pfeiffer como Mulher Gato 


\section{JEAN-PIERRE JEUNET}

Outro cineasta contemporâneo bastante influenciado pelas artes plásticas e gráficas é o francês Jean-Pierre Jeunet ${ }^{37}$, diretor de Delicatessen (1991), Ladrão de Sonhos (1995) e O Fabuloso Destino de Amelie Poulain (2001), junto com Marc Caro.

Assim como Fellini e Bergman, quando criança já experimentava o gosto de criar seus pequenos espetáculos, contando histórias por meio das imagens "vivas" de um teatro de fantoches, elaborando ele mesmo os bonecos, iluminação, cenários e figurinos em apresentações familiares.

Pode-se observar em sua filmografia a influência das histórias em quadrinhos: pela estilização das figuras e os traços exagerados dos personagens, de modo a enfatizar certas características de sua personalidade ou certos ânimos, assim como dinâmicas, do roteiro. Jeunet prefere a estilização ao realismo no cinema. Não vê razão na reprodução da vida tal como ela é. Assume, em virtude disto, sua preferência por Kurosawa e pelos cinemas italiano de Federico Fellini e americano de Tim Burton em detrimento do cinema francês ${ }^{38}$, cuja tradição é muito mais realista.

A influência de Fellini em sua obra nota-se de modo geral pela construção poética da imagem. Especificamente, podemos notar sua influência nos filmes Delicatessen e Ladrão de Sonhos, por meio da representação do mundo do circo. O senso de humor é outro traço comum, o "pensamento mágico" dos personagens, que se comportam de maneira, muitas vezes, ritualística (Ezra, 2008, p.8). Ambos são autores populares, que possuem sua "marca registrada" sem deixar de lado a sofisticação, ou a profundidade de sentido ao contar suas histórias, nem em termos de imagem, nem de idéias e personagens.

Jeunet põe em foco as preocupações do presente através de questões como a mediação tecnológica das relações humanas e a ansiedade cultural acerca dos avanços na biotecnologia, e mantém em pauta uma temática bastante felliniana - a do não-entendimento entre as pessoas.

\footnotetext{
${ }^{37}$ Jean-Pierre Jeunet nasceu em 3 de setembro de 1953, em Roanne, na França.

${ }^{38}$ Entrevista de Jean-Pierre Jeunet concedida à BAFTA, Londres, $A$ Life in Pictures: http://www.youtube.com/watch?v=HndWfBhvQrk, acessado em 30 de maio de 2010.
} 
O diretor costuma trabalhar com as mesmas pessoas em sua equipe, roteirista, cenógrafo, produtor de objetos, fotógrafo, atores... Constrói parcerias duradouras. Um exemplo disso é Marc Caro, co-diretor dos principais filmes de sua carreira.

A escolha dos atores, para ele, não está calcada apenas na capacidade de interpretação, mas também nos tipos físicos e em suas fisionomias, como fazia Fellini. O ator Daniel Emilfork que faz o papel de Dr. Krank em Ladrão de Sonhos também foi escalado por Fellini no filme Casanova para fazer um inseto, tão curiosa a sua feição. São rostos bastante caricaturais, expressivos para o que ele deseja revelar. Podemos notar os rostos preferidos do diretor e como são usados de modo a acrescentar à história e ao personagem em questão.
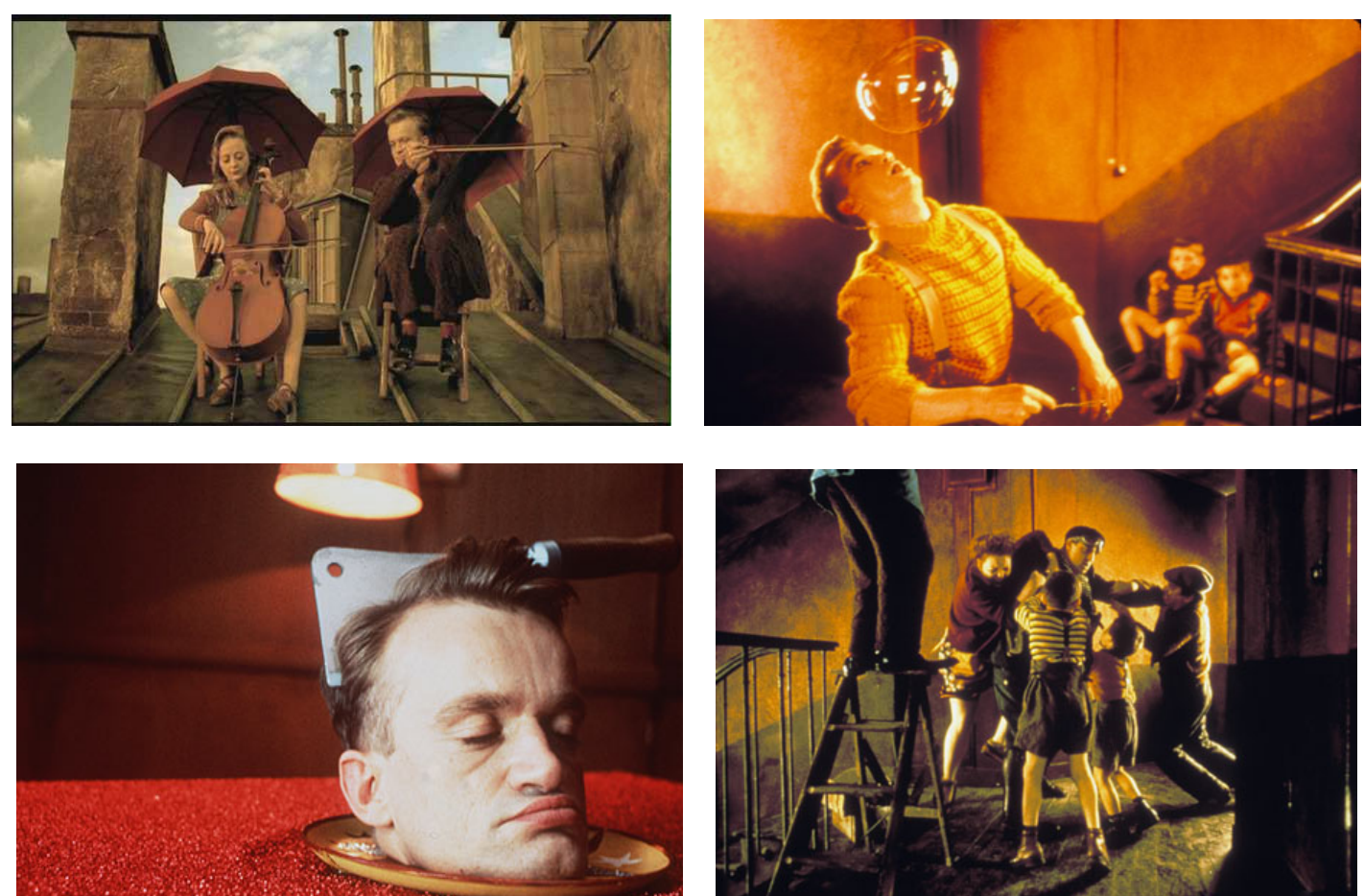

Imagens 19, 20, 21 e 22 Cenas do filme Delicatessen, de Jeunet

Jeunet não produz desenhos como Fellini, mas se preocupa muitíssimo com o aspecto visual de seus filmes, trabalhando bastante junto com Marc Caro, responsável pela direção artística. Gosta de jogar com todos os elementos que o cinema lhe proporciona tendo-os sob seu controle do início ao fim. A chave de seu trabalho está no período de pré-produção do filme, quando planeja todos os detalhes minuciosamente e os repassa à equipe. Seus roteiros passam por muitas versões - no caso de Amelie Poulain foram 18 - na busca incansável pelo melhor modo de contar a história. Por último trabalha 
ainda no storyboard, definindo todos os enquadramentos e movimentos de câmera.

Em Amelie Poulain são 80 cenários. A unidade expressiva de seu filme só existe por haver um rigor com a escolha das locações e pela preocupação em encontrá-las. Além, é claro, de todo o planejamento da direção de arte e produção de arte, que irá costurar todos estes ambientes e transformá-los nas atmosferas ideais. É o primeiro filme de Jeunet feito fora de um estúdio em situações externas, o que o aborreceu muito a princípio, pelo fato das coisas não poderem estar todas em seu controle, por não serem mais todos os detalhes passíveis de manipulação.

Por ser Jeunet um diretor bastante rigoroso com as cores utilizadas em seu filme, para ressaltar o que ocasionalmente não tenha sido alcançado durante as filmagens, optou passar por um processo de colorização da película. Amelie Poulain, usou por um processo conhecido como bleach by pass, onde as cores são saturadas e pode-se dar um tom mais esverdeado se desejar $^{39}$.

O uso predominante de verdes e vermelhos neste filme acrescenta sensivelmente um caráter vibrante à história, às imagens, vistas pelo ponto de vista deste personagem. Empresta certo toque de irrealidade ao seu cotidiano, o que combina com o ar de fábula que tem esta narrativa. Obviamente há uma predominância destes dois tons, o que não quer dizer que outros tons não sejam usados. Amelie Poulain é um filme muito rico em cores. Outros tons são usados na intenção de equilibrar os primeiros, impedindo que as imagens se tornem por demais previsíveis.

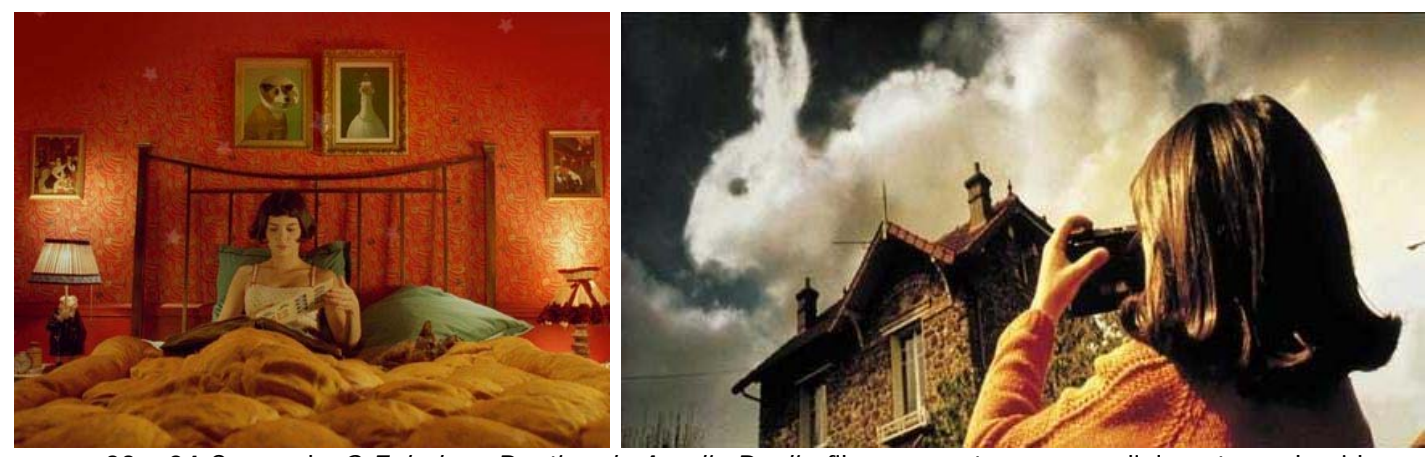

Imagens 23 e 24 Cenas de O Fabuloso Destino de Amelie Poulin, filme que o tornou mundialmente conhecido

${ }^{39} \mathrm{O}$ efeito é parecido com fazer fotografias em película ectachromo, de slide, e revelar no processo positivo. O resultado são fotografias bastante contrastadas, com tons de pele um pouco amarelados ou esverdeados, dependendo da incidência de luz,e cores mais saturadas de modo geral. 
Defensor de um "cinema da imaginação", Jeunet fala disso em seus filmes - da necessidade dos pequenos prazeres da vida, dos sonhos, da criatividade na vida cotidiana.

Em O Ladrão de Sonhos, vemos uma sociedade onde não se sonha. Os que possuem um papel dominante nesse lugar tentam roubar os sonhos das crianças para não sucumbir de infelicidade, embora a imponham a todos que vivem sob seu julgo. Porém, tendo feito da vida dessas crianças um verdadeiro inferno, só conseguem extrair delas os seus piores pesadelos.

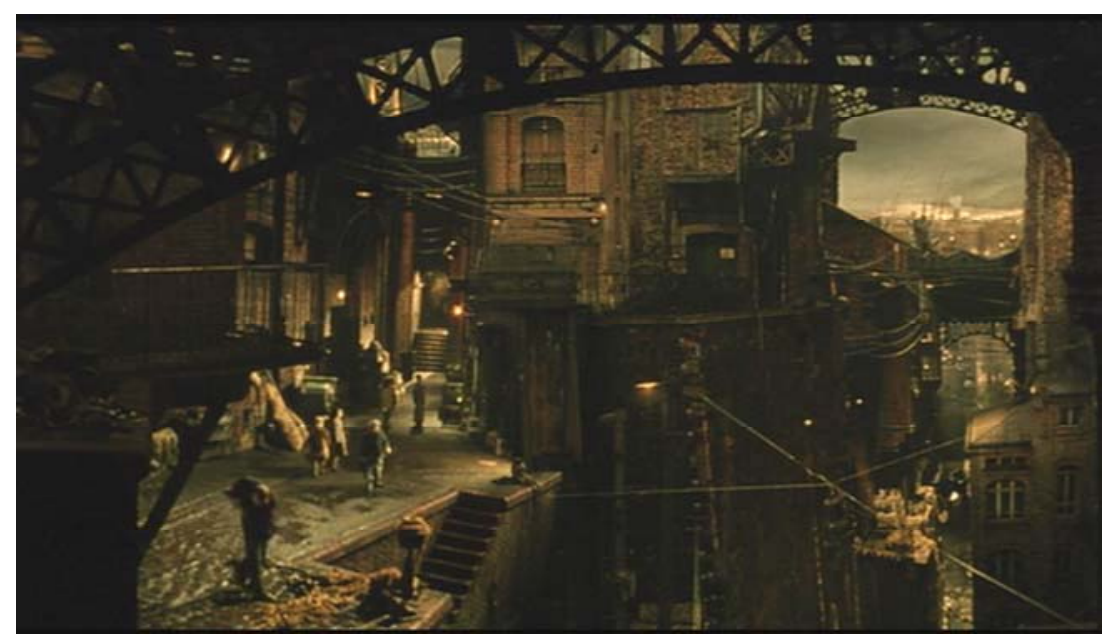

Imagem 25 Imagem extraída do filme Ladrão de Sonhos - cenário da cidade

Nessa fábula as crianças são vestidas como adultos. A menina Miette (ou Migalha, como é traduzido seu nome no Brasil), que é a heroína do filme, usa na primeira parte da história um casaco comprido de lã cinza, que é uma fase mais pessimista de seu personagem. Mas depois, ao reencontrar sua essência no afeto, com o personagem One, sai de cena o casaco e aparece o que está por baixo desta camada; seu figurino mais infantil e mais colorido: jardineira-saia vermelha e blusa de lã branca com listrinhas vermelhas horizontais.
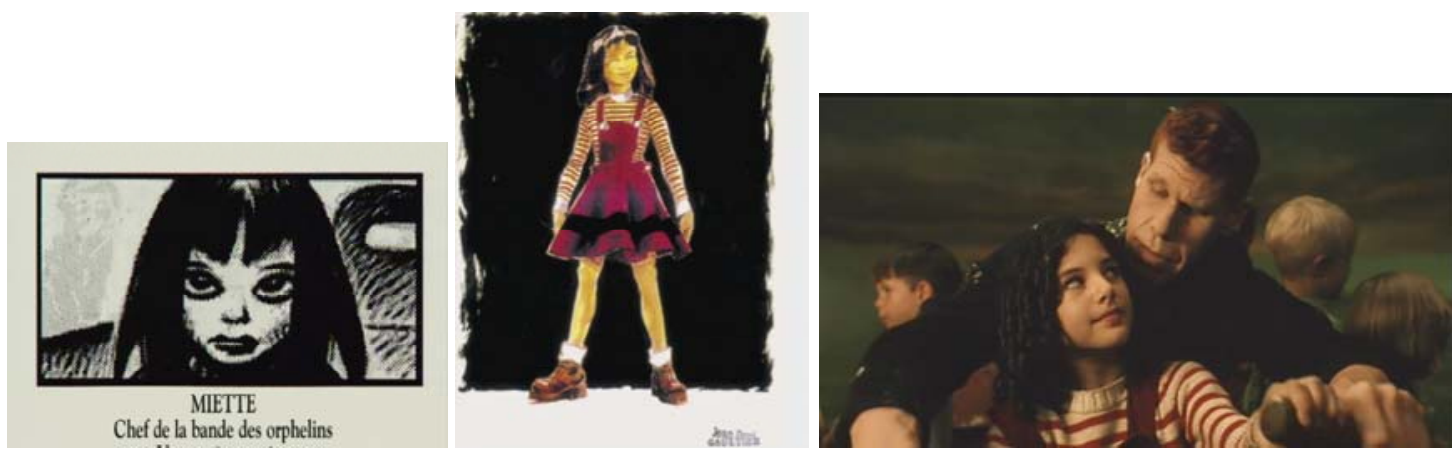

Imagens 26, 27 e 28 Desenho feito por Marc Caro para personagem Miette, croqui de Gautier e personagens em cena - Miette e One 
Como é a única das crianças a ter coragem de tentar resolver as coisas, é a única com figurino colorido e mais infantil, (de forte influência dos desenhos animados, algo entre Olívia Palito e Minnie Mouse).
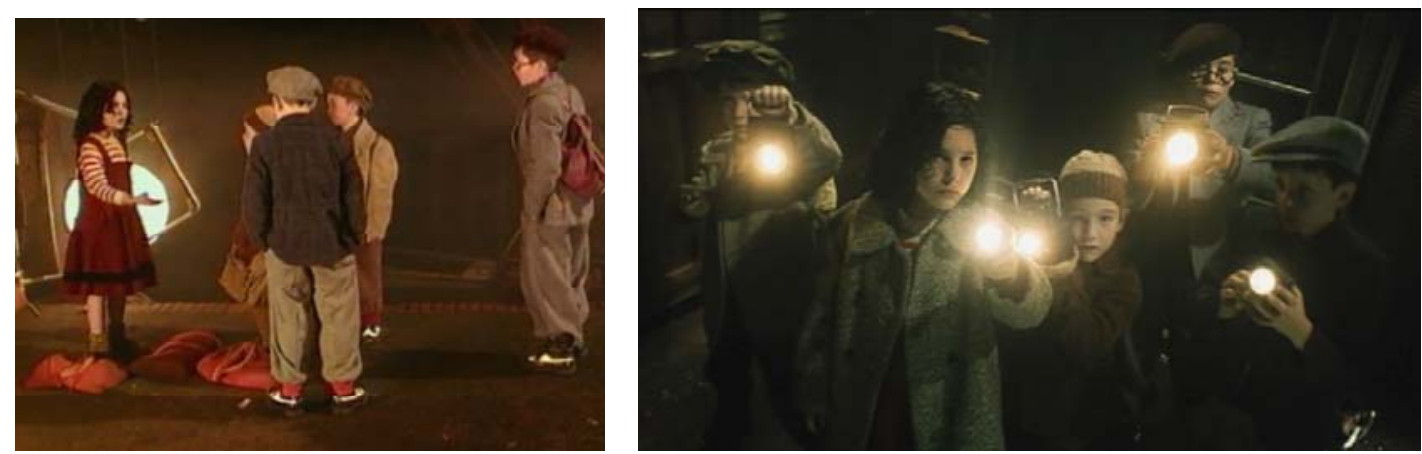

Imagens 29 e 30 Miette e outras crianças - Figurino infantil e adulto

São vistos muitos animais ao longo deste filme, o que se justifica lembrando que animais geralmente acompanham o universo fantástico, principalmente se são aceitos normalmente dentro da narrativa como passíveis de ação. Assim como nos filmes de Fellini, a presença de animais nos lembra a infância e os contos de fada. Os animais existem onde as coisas selvagens estão (ROHDIE, 2002, p.147).

Entre os "vilões", vemos muitos personagens "iguais" - há os clones e há as siamesas. Que, no entanto, se perguntam a todo momento sobre quem é "o original" e quem é a imitação.

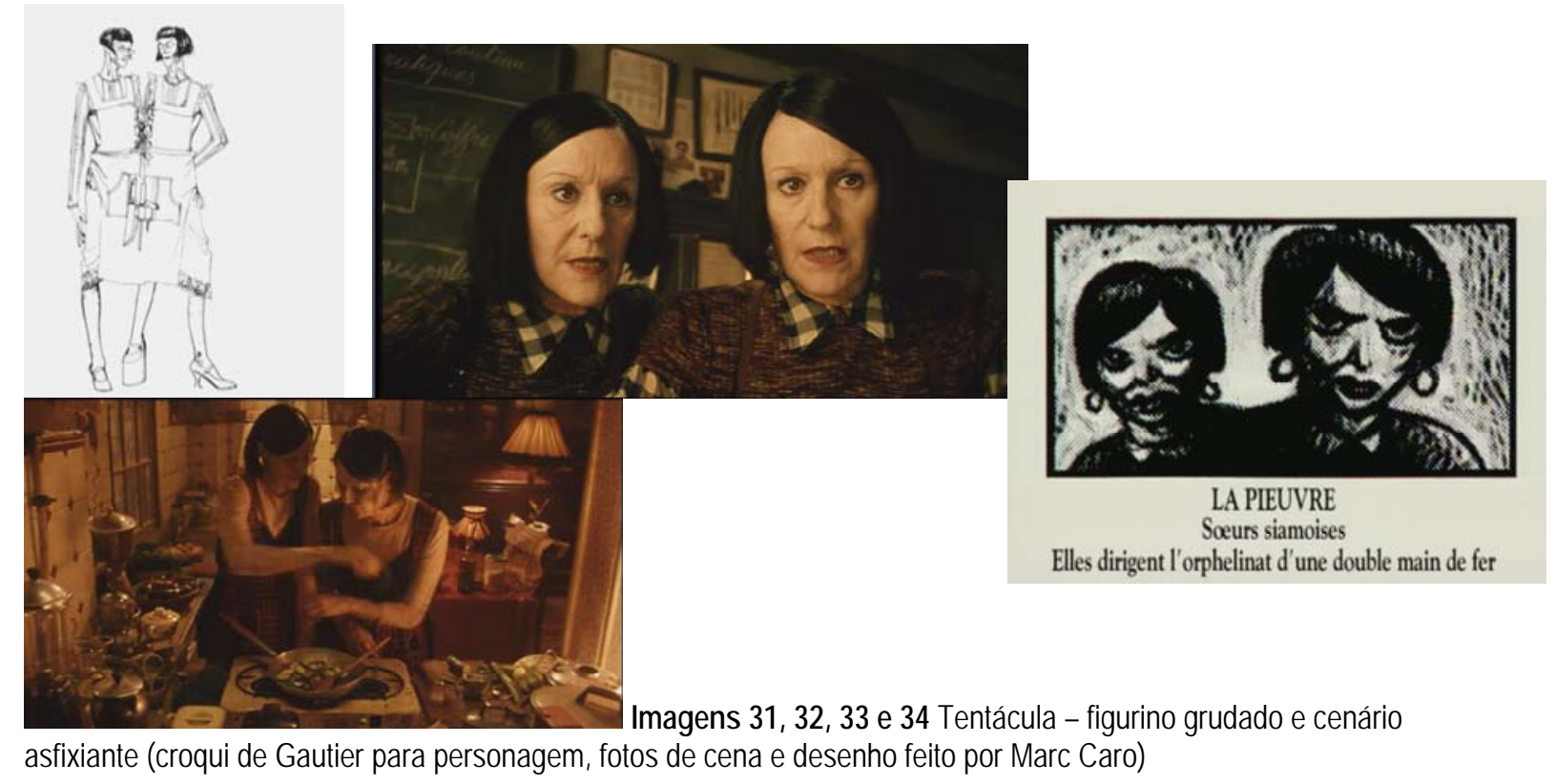




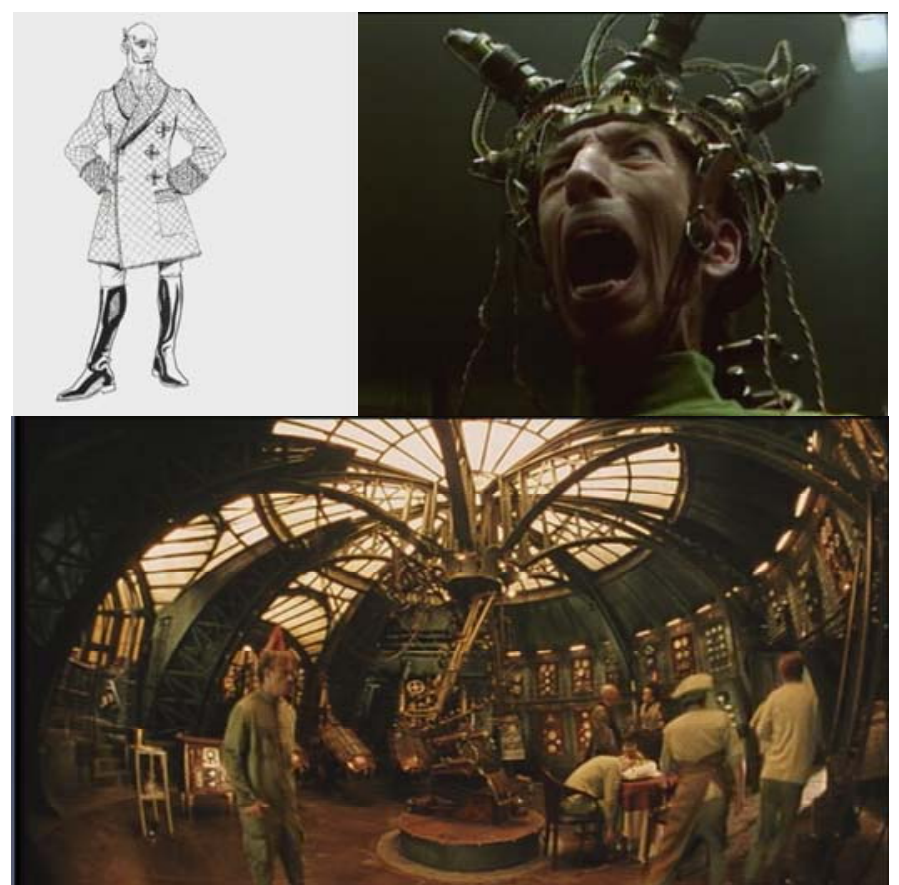

Imagens 35, 36 e 37 Croqui de Gautier para Dr. Krank, ator Daniel Emilfork que interpreta o papel e cenário que divide com os clones

Do outro lado dos personagens, há uma busca por um "irmão", uma identificação fraterna com alguém, uma sensação de pertencimento afetivo. E curiosamente, já no início do filme vemos o grandalhão One procurar pelo pequenino Petisco, menino seqüestrado pelos ladrões de sonhos, chamando-o de "irmãozinho". Assistimos acontecer a identificação entre os que não se parecem, na superfície, indicando que há muito mais por trás da aparência das coisas.

Jeunet também põe em questão em seus filmes a diferença, o preconceito, o personagem marginalizado, incompreendido num mundo atroz. One, cujo próprio nome já indica, é único, sem par no mundo.
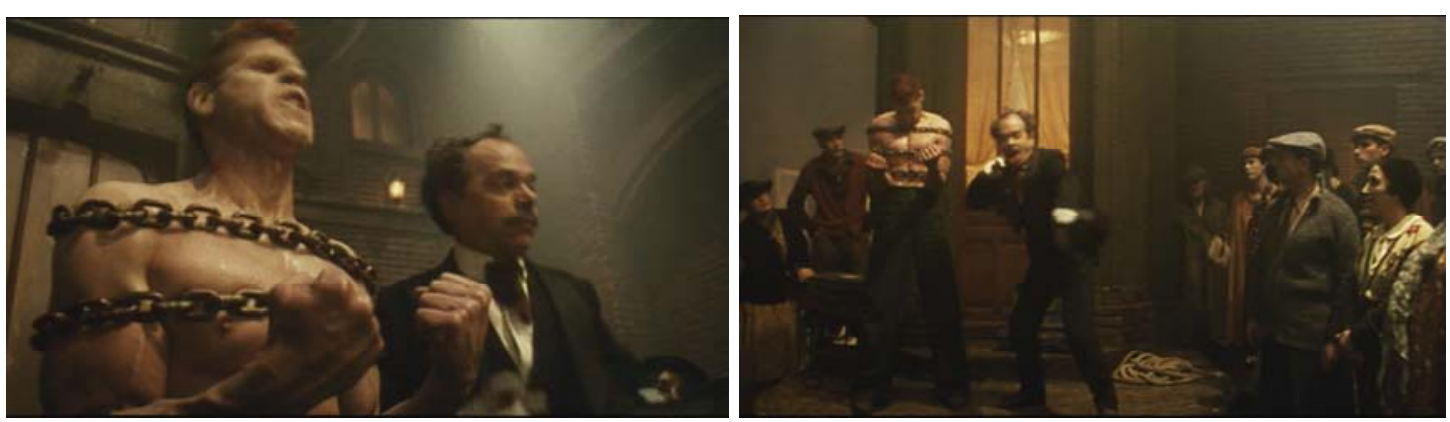

Imagens 38 e 39 One e 0 apresentador do espetáculo de rua - número idêntico ao de Zampanò

Talvez seja uma referência a La Strada de Fellini, o fato de esse personagem nos ser apresentado em um espetáculo de rua, em que ele arrebenta correntes pela expansão de seus pulmões, sem camisa, usando uma 
calça muito parecida com a que Anthony Quinn usava. Mas, diferentemente de Zampanò, ele não é o dono do espetáculo. Ele está sendo apresentado por outro, que explora suas qualidades físicas. One é tido, de certo modo, apenas como uma aberração.

É um mundo da desvalorização da alma. One faz parte de um espetáculo mambembe que está prestes a morrer como arte de rua, como o seu próprio apresentador, que em seguida é assassinado por alguém do público. Este espetáculo mesmo, despreza sensibilidades e é calcado na força bruta. Para piorar, quem tenta roubar o dinheiro da caixinha dos artistas são as próprias crianças. Um mundo sem ética ou respeito, sem sonho, sem infância e sem cores. Jeunet mais uma vez se vale do verde e do vermelho prioritariamente - mais verde do que vermelho, indicando um mundo adoecido.
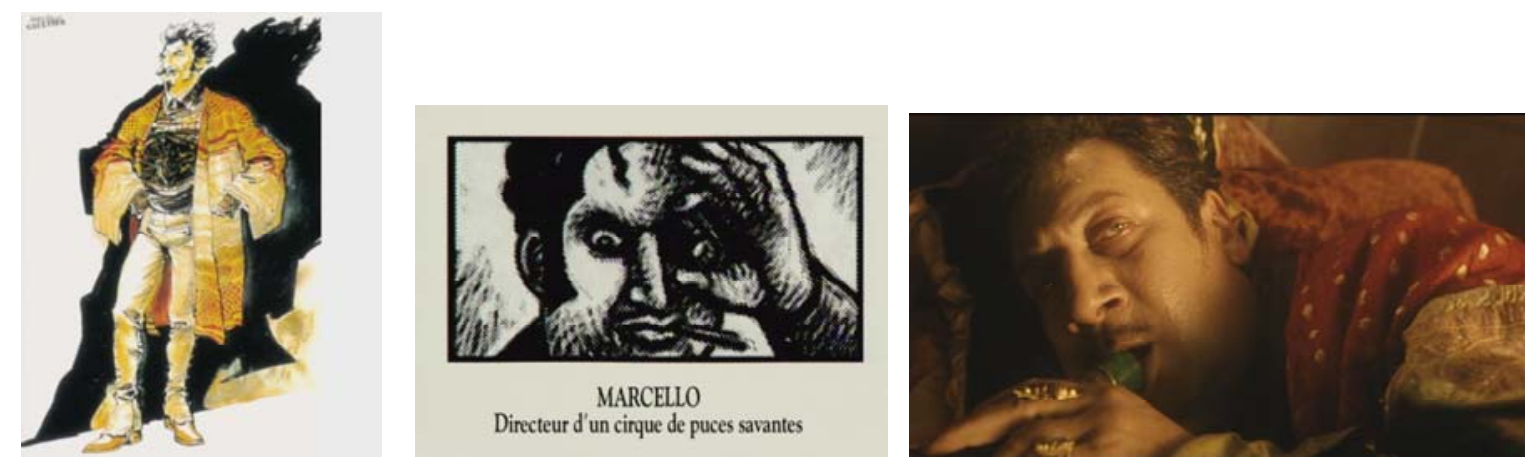

Imagens 40, 41 e 42 Desenho feito por Marc por Caro para o personagem Marcelo, e 0 ator Dreyfus no papel
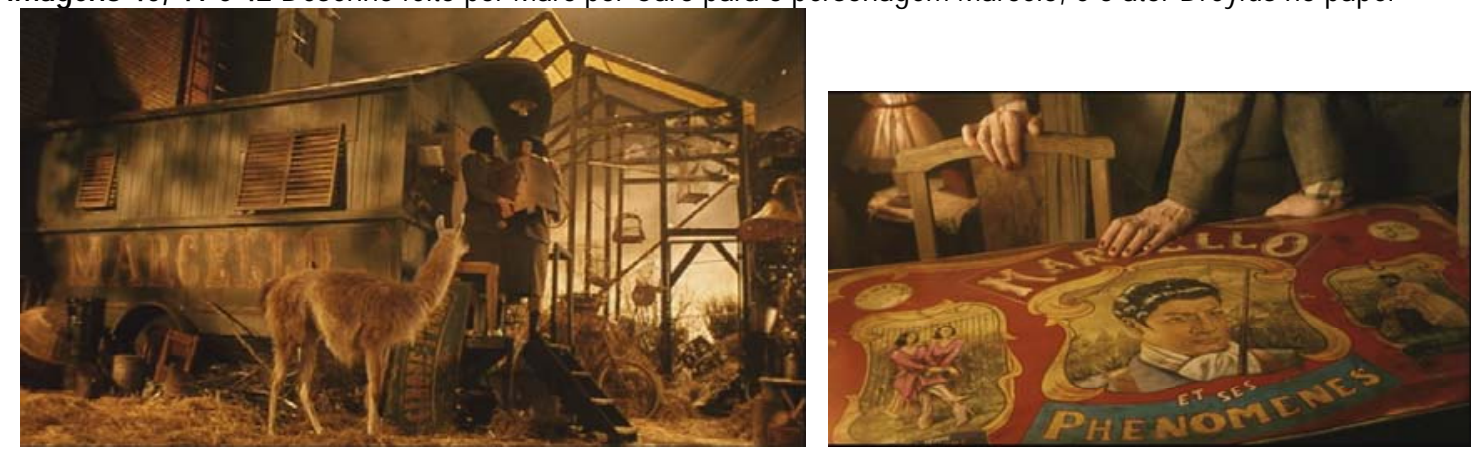

Imagens 43 e 44 Trailer do diretor de circo e uma peça de seu cenário

Outro personagem circense é o diretor do circo, que vemos deprimido em sua casa, destituído de sua função de realizador, já que o circo está arruinado por ter se deixado contaminar pelos personagens dominantes.

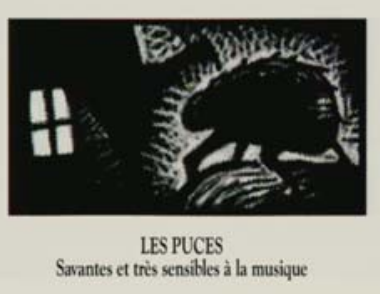

Imagem 45 Desenho feito para Pulga por Marc Caro 
Jeunet agrega valor especial ao circense, ao que é mágico, genuíno e inocente, por meio do papel salvador dado a este personagem: quando acionado, salva Migalha e One com suas pulgas amestradas sensíveis à música. Jeunet fala, de leve, sobre o poder transformador da arte e acredita nele, ao escolher o tipo de cinema que faz.

Sobre a colaboração dos cenários no processo de construção dos personagens, há um depoimento dado pelo cenógrafo do filme, Jean Rabasse, muito significativo:

Esse filme é, sobretudo, a tentativa de criar um universo com personagens muito fortes, com situações muito fortes, e com convicções muito fortes.

Tentamos sempre encontrar uma premissa para justificar os cenários. Não era apenas uma imagem de fundo, era um tipo de arquitetura que devia acompanhar completamente os personagens.

Quanto à cor, tivemos que escolher a luz, a película e o contraste. Nós usamos pinturas como base. Fizemos algo que não se faz há 40 anos na França: um filme feito inteiramente no estúdio. Para ajudar, misturamos as técnicas antigas de construção em estúdio, com as técnicas de pintura e imagem sintetizada que nos permitiram dar uma dimensão ao porto. ${ }^{40}$
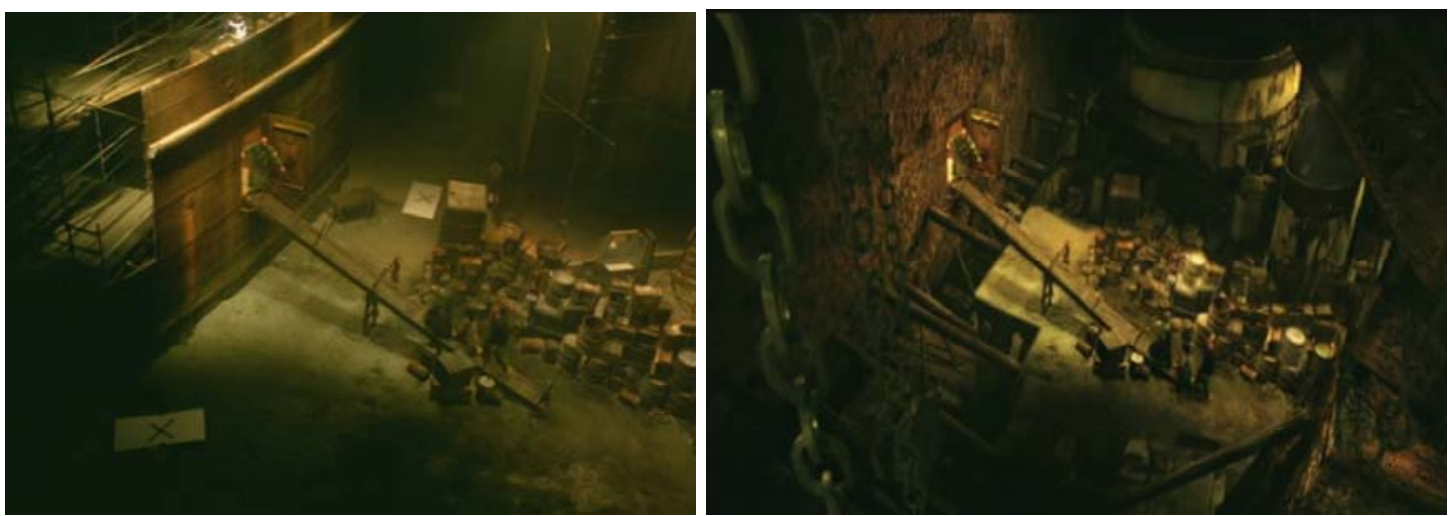

Imagens 46 e 47 A imagem como foi captada e, à direita, com as texturas aplicadas em pós produção

\footnotetext{
${ }^{40}$ Making off do filme O Labirinto do Fauno inserido no DVD.
} 

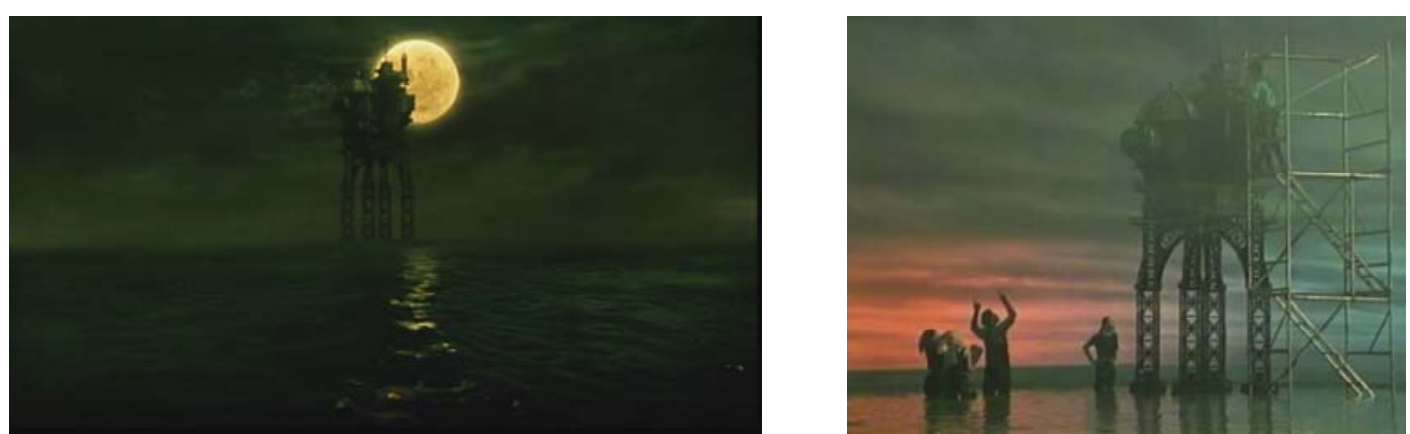

Imagens 48, 49 e 50 Acima, cenário de mar e plataforma ilhada do laboratório - em cena do filme e durante período de preparação pela equipe de cenotécnicos. Abaixo, imagem do porto com o barco aportado feita durante a preparação do filme

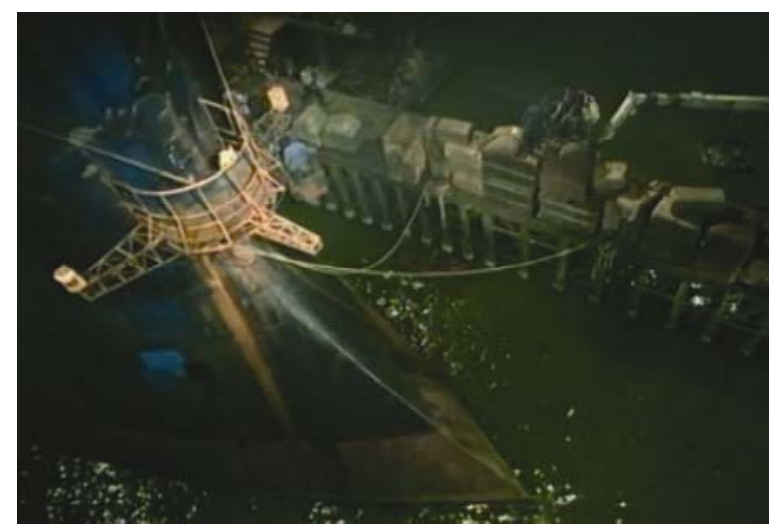

Os cenários foram montados no Arpajon Stúdios e ocupavam ao todo quatro mil metros quadrados, afinal, toda uma cidade cenográfica foi construída, com casas, lojas, bares, ruas e um porto, fora o mar artificial, feito com água mesmo - tinha $80 \mathrm{~cm}$ de profundidade. Os enormes barcos chegavam a ter 14 metros de altura e eram puxados por tratores nas cenas em que precisavam mover-se. 


\section{GUILLERMO DEL TORO - LABIRINTO DO FAUNO}

O cineasta mexicano, Guillermo Del Toro ${ }^{41}$, não possui obras suficientes em sua carreira que partilhem do estilo em questão para ser considerado neste trabalho entre os influenciados pela arte de Fellini. No entanto, há um, entre os seus filmes mais recentes, O Labirinto do Fauno, que merece ser comentado, assim como as declarações do cineasta sobre o seu modo de fazer cinema.
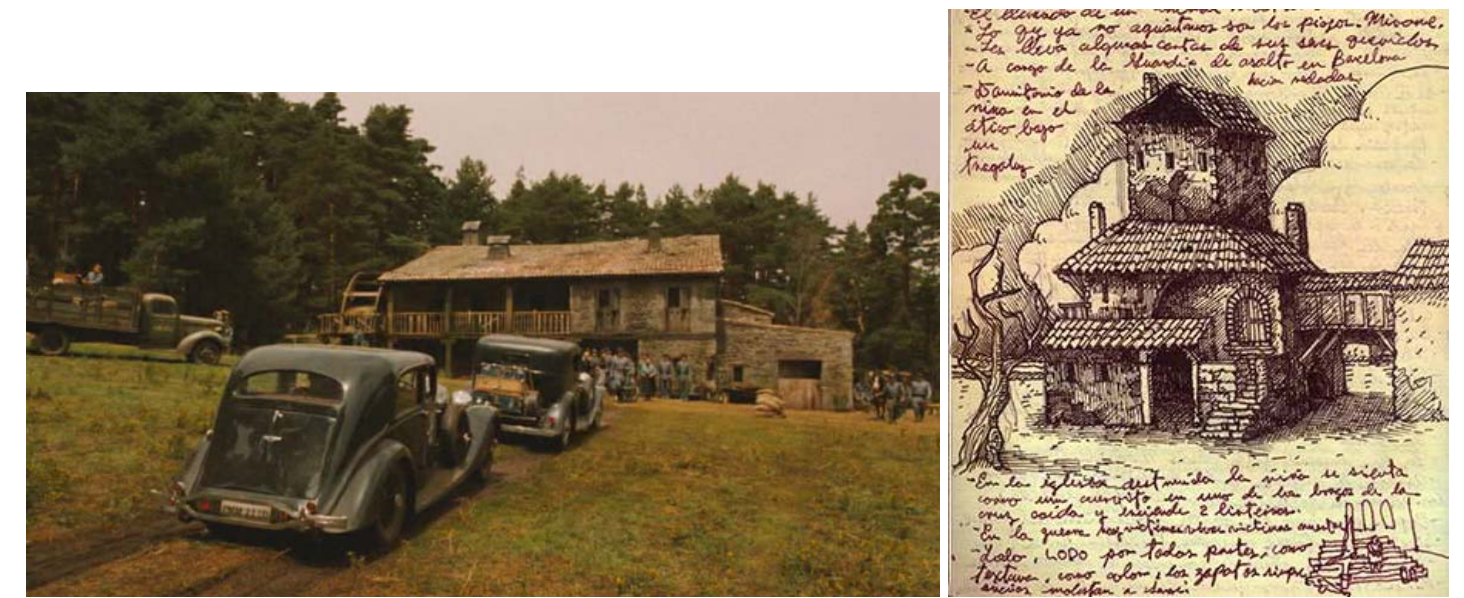

Imagem 51 Foto da casa do Capitão Vidal, ambientada na Espanha, 1944 Imagem 52 Desenho de Del Toro para casa do Capitão ou moinho

Del Toro, comentando este seu trabalho, declarou: "cada cenário representa o pensamento de um personagem" ${ }^{42}$. Ele, assim como Jeunet, para ter mais controle sobre suas composições, prefere filmar em cenários construídos do que em locações. Alega serem mais "cinematográficos", ou seja, verossímeis e menos realistas.

Assim, O Labirinto do Fauno foi feito todo em estúdio, salvo as cenas externas, no bosque. Se passa em dois mundos paralelos e concomitantes - 0 real e o imaginário. O real é datado na Espanha, em 1944, enquanto o imaginário, não tem base em nenhuma época específica. Nele encontramos o personagem Ofélia, cujo pai, alfaiate, morreu na guerra espanhola, e cuja mãe, viúva, acaba se casando com o terrível capitão do exército franquista, Vidal. A protagonista é oprimida de todas as formas pelo universo em que é obrigada a se inserir. Sendo uma criança sensível, usa a literatura, os contos de fadas, sua imaginação, como um refúgio e como um recurso para fortificar-se e enfrentar os perigos que a esperam.

\footnotetext{
${ }^{41}$ Guillermo Del Toro nasceu em 9 de outubro de 1964, em Guadalajara, no México.

${ }^{42}$ Comentários extraídos do making off de Labirinto do Fauno.
} 
Neste filme o que está em evidência é o poder transformador dos que não se dobram aos mandos irracionais e dominadores e se mantêm em busca de uma sociedade mais justa, mais livre. Na mesma medida, está evidenciado o poder transformador e revigorante da arte, aqui na forma da literatura. Ambos os ideais parecem "quixotescos", mas ambas as heroínas deste filme (a garota Ofélia e a governanta Mercedes) estão dispostas a sacrificar-se pelo resgate de seus mundos, o da imaginação e o de uma Espanha democrática, respectivamente.

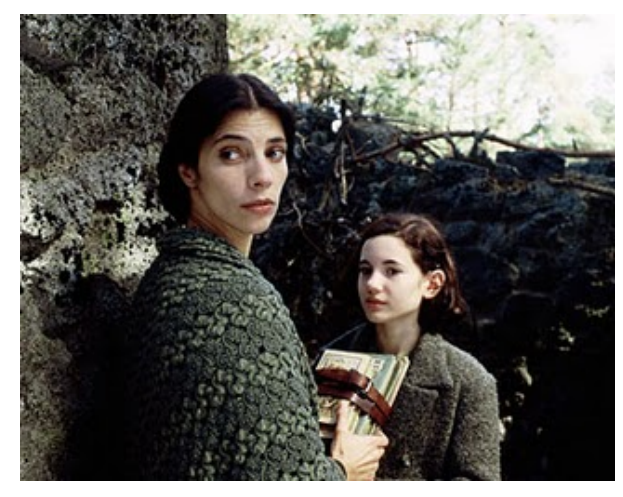

Imagem 53 Da esquerda para direita, as atrizes Maribel Verdú e Ivana Baquero, interpretando Mercedes e Ofélia

A história é contada com uma estrutura de fábula e registra o conflito entre os que abraçam a diversidade (Ofélia, com seu profundo respeito pelas criaturas mais estranhas que lhe aparecem) e os que tentam aniquilar todos os que lhe são diferentes (os fascistas).

Del Toro é um diretor bastante visual e constrói muito bem seus personagens pelo viés plástico. Por exemplo, traduz o personagem do capitão por linhas retas e pela monocromia. Assim, há muitas máquinas, engrenagens em seus cenários, mas nenhum aconchego. Todas as suas ações são precisas e parecem repetidas, sem emoção: o ato de fazer a manutenção do relógio que havia sido de seu pai, fazer a barba com a navalha de modo ameaçador, lustrar as botas... Há algo de muito impecável e duro na sua aparência, assim como em tudo o que é seu.

Só se vê afetividade neste personagem na sua relação com a memória do pai, a qual se manifesta na relação estabelecida com o relógio de bolso que, sabemos, pertencera a ele. Ao depositar toda a sua capacidade de afeto no objeto, transparece seu desejo de ser amado, admirado pelo pai, já morto. As posturas do capitão assim, são sempre posturas duras, espelhadas em como devem ter sido as desse pai, também militar. Ao perpetuar o desejo de igualarse ao pai, de ser merecedor de seu afeto, perpetua também a secura de um mundo em guerra, cego, intolerante e injusto. 

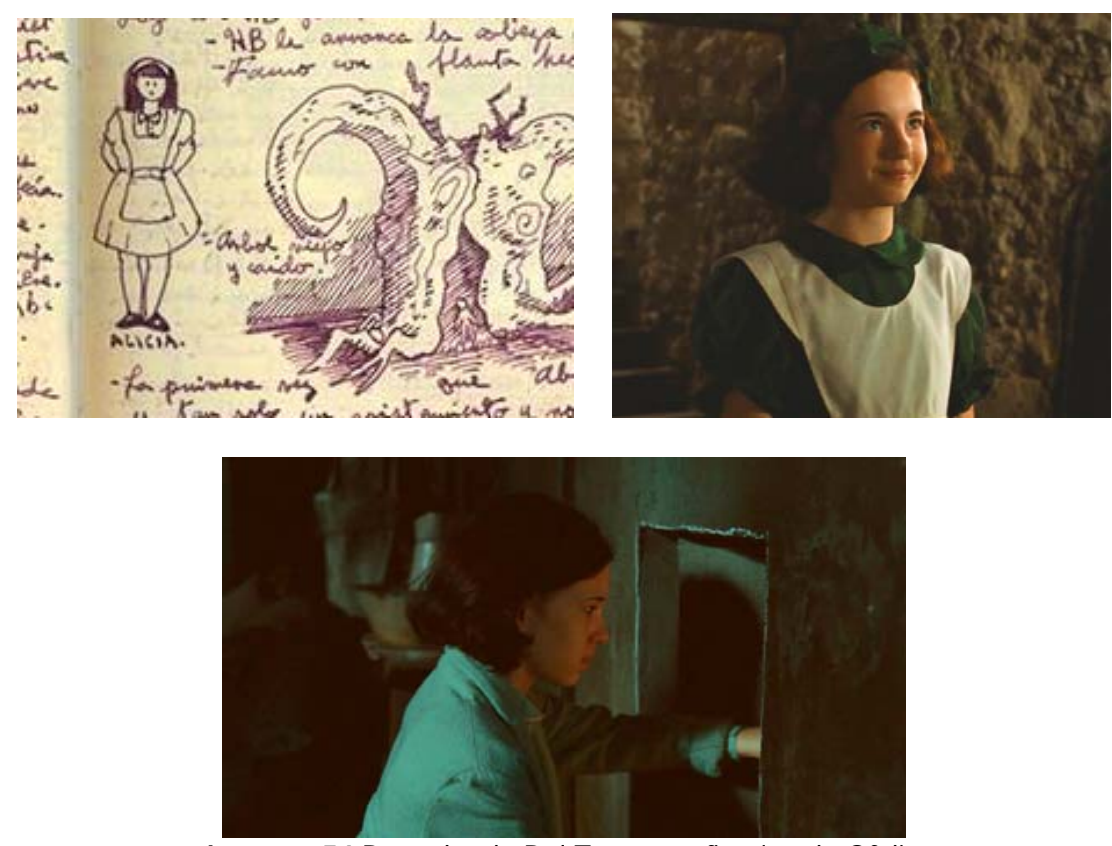

Imagem 54 Desenho de Del Toro para figurino de Ofélia Imagens 55 e 56 Dois figurinos de Ofélia

Quanto aos figurinos de Ofélia, são bastante infantis e femininos, caracterizando sua inocência e pureza. Fazem uma referência aos figurinos conhecidos pelas ilustrações de "Alice no País das Maravilhas", de Lewis Carrol (a própria narrativa de Del Toro também faz esta referência à medida que a faz passar por uma pequena porta, que ela mesma desenha pela parede para atravessar). A sua paleta é verde, o que o aproxima das cores do bosque, da natureza e do personagem do Fauno. Este por sua vez possui um corpo com texturas de árvore e a cabeça com características de cabra (olhos, orelhas, chifres, focinho), identificando sua personalidade com elementos naturais de "flora e fauna".
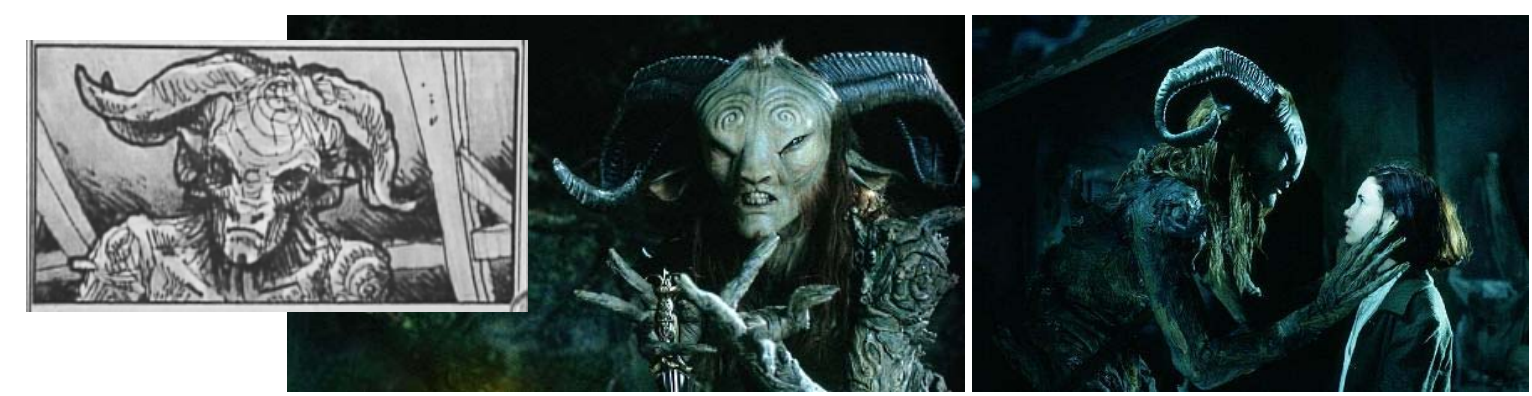

Imagens 57, 58 e 59 Desenho do fauno extraído de storyboard de Raul Monge e cenas do filme em que ele contracena com Ofélia 

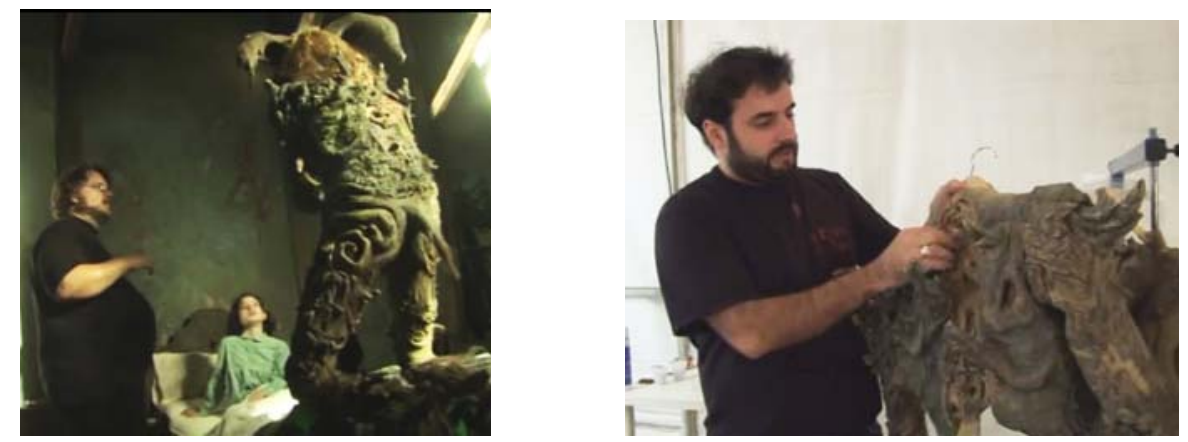

Imagens 60, 61 e 62 Del Toro no set com Ofélia e Fauno; equipe de caracterização mostrando roupa de Fauno

Outro ser bastante fantástico e completamente criado por este diretor é a figura pálida que encontramos sentada àquela gigantesca mesa servida com um banquete. Ele pode ser visto como uma metáfora da crueldade exercida pode esconder-se, permanecer adormecida sob determinados terrenos, e vir à tona quando menos se espera.
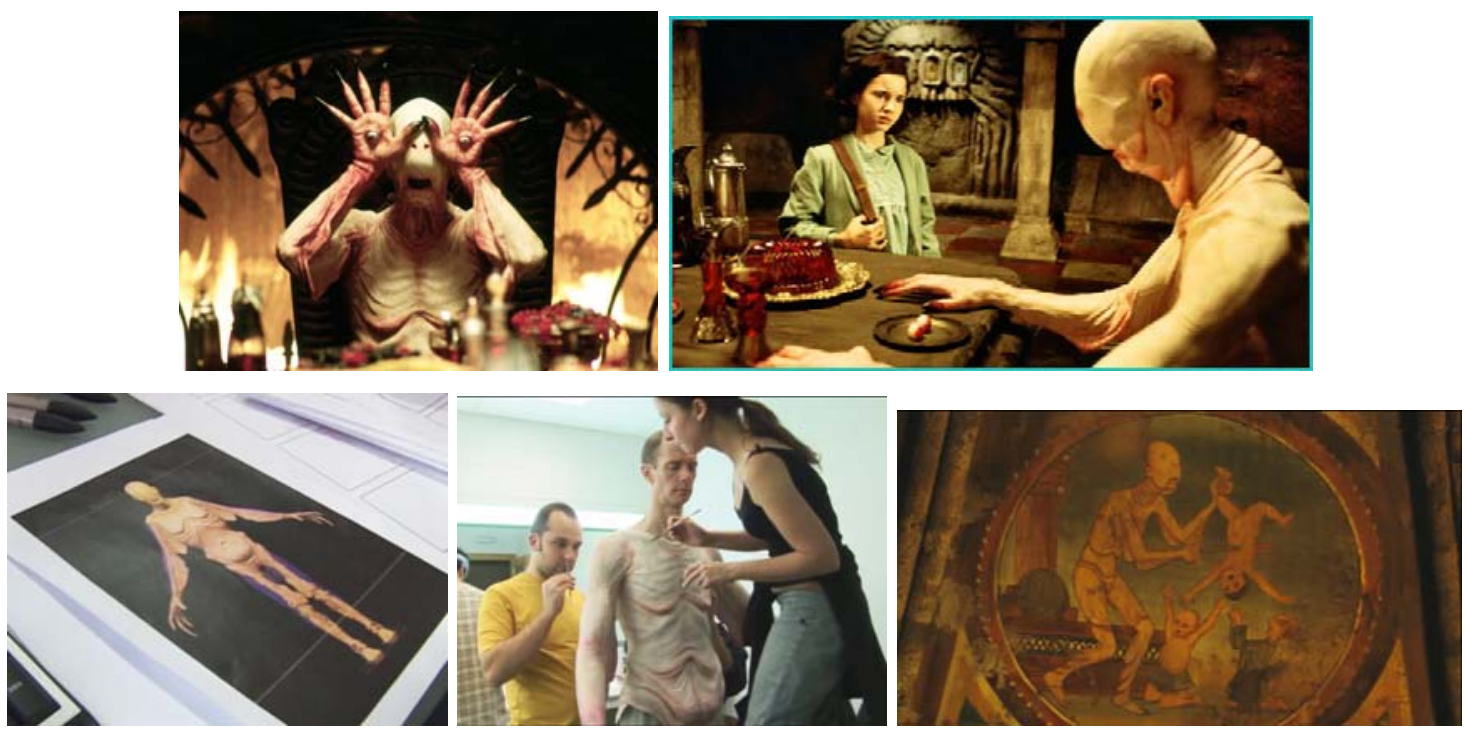

Imagens 63, 64, 65, 66 e 67 Cenas com o Homem pálido interpretado por Doug Jones, mesmo ator que interpreta 0 Fauno; desenho para guiar trabalho de maquiadores; processo de maquiagem no ator; e um dos afrescos inseridos no cenário

Trata-se de um ser que mesmo podendo se alimentar de toda a comida a seu alcance, prefere devorar a vida das pessoas, na figura de crianças - ou seja, as pessoas que tiverem mais juventude, energia, sonhos, liberdade de pensamento. Pessoas para as quais, inclusive, este banquete está proibido. Quanto a seu aspecto plástico, além de ser assustador como sua personalidade, é murcho, disforme e sem cor - o que reflete o fato de não possuir mais vitalidade em sua essência e ter que buscá-la fora de si.

Del Toro, cineasta acostumado a lidar com o impacto da imagem por meio de todo o estudo de maquiagem que norteou o início de sua carreira, 
construiu com Labirinto do Fauno uma obra imagética de enorme força e potencial artístico.

\section{LUIZ FERNANDO CARVALHO}

No Brasil, onde o nosso cinema "engatinha" quando comparado ao processo histórico vivenciado pelos históricos "gigantes", penso primeiramente em Luis Fernando Carvalho ${ }^{43}$. Coincidência ou não, o diretor também gostava de desenhar desde criança e trabalhou em sua juventude fazendo ilustrações para jornais e revistas. Seu trabalho com a linguagem audiovisual começou com o curta-metragem A Espera, premiado em 1986. Seguiu como assistente de direção em TV e se firmou no meio tornando-se diretor de telenovelas e minisséries bastante renomadas. Em 2001, retorna aos cinemas realizando o longa-metragem Lavoura Arcaica, impecável na interpretação, na adaptação literária do romance homônimo de Raduan Nassar e na plasticidade orgânica e rústica, inerente ao texto.
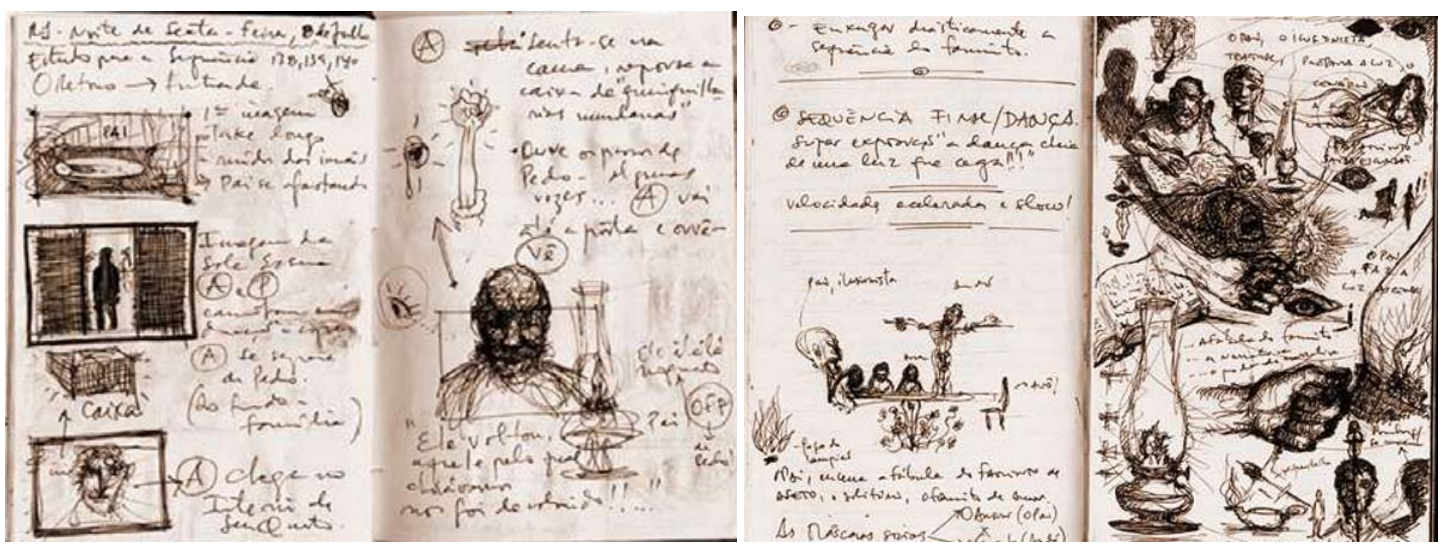

Imagem 68 Desenhos e anotações de Luiz Fernando Carvalho para seu filme Lavoura Arcaica

Seus trabalhos mais recentes em televisão - Hoje é dia de Maria, A Pedra do Reino e Capitu - se destacam de tudo o que é usualmente produzido. A minissérie Hoje é dia de Maria havia sido um projeto de ficção que previa o uso de diferentes técnicas, incluindo a de animação stop motion, mas ficou engavetado por anos na emissora. Carvalho não desistiu e incrementou o projeto até ser aceito em 2005. Hoje é dia de Maria se tornou um enorme sucesso de critica e audiência. Infelizmente, a audiência não acompanhou seus

\footnotetext{
${ }^{43}$ Luiz Fernando Carvalho de Almeida, nasceu em 28 de julho de 1960, na cidade do Rio de Janeiro.
} 
trabalhos seguintes, os dois primeiros trabalhos do Projeto Quadrante da TV Globo - A Pedra do Reino e Capitu. Embora tenham tido excelência em todos os sentidos, tais adaptações literárias, que mantinham os textos originais na dramaturgia, talvez tenham representado um grau maior de dificuldade para 0 público. Somada esta dificuldade à estética diferenciada, o diretor parece ter encontrado obstáculos para dar sequência às suas idéias na emissora.

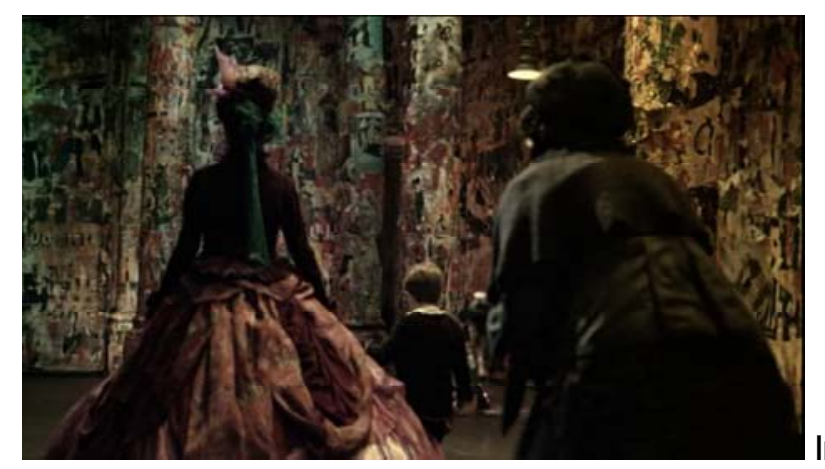
jornal pelas paredes - metáfora para as camadas do tempo, da personalidade, da interpretação dos fatos

No trabalho de Carvalho destaco a ousadia no modo de fazer a cenografia e o figurino, principalmente se formos considerar que ele o fez no meio televisivo, muito mais comercial do que o cinema, e, portanto, muito mais difícil de se realizar trabalhos ousados. Raimundo Rodriguez, artista plástico que foi chamado para a direção de arte dos projetos, trabalha com sucata e materiais reaproveitados. Por exemplo, alguns móveis e cortinas em Capitu foram feitos de jornal, em homenagem a Machado de Assis que havia trabalhado como cronista no Rio de Janeiro.

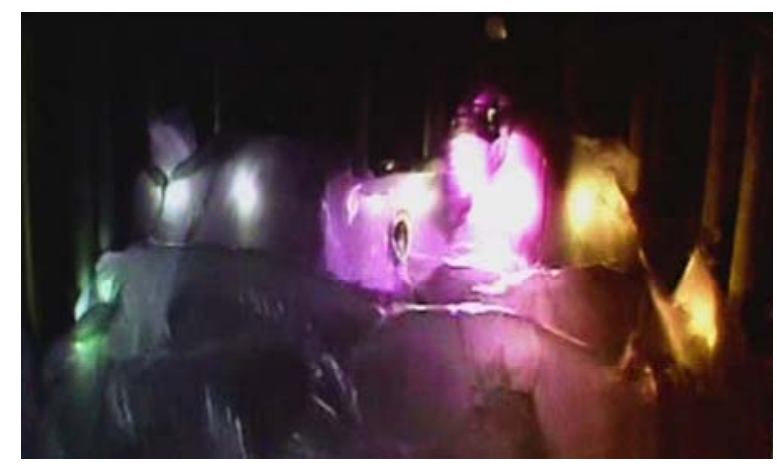

Imagem 70 Afogamento de Escobar -making off 


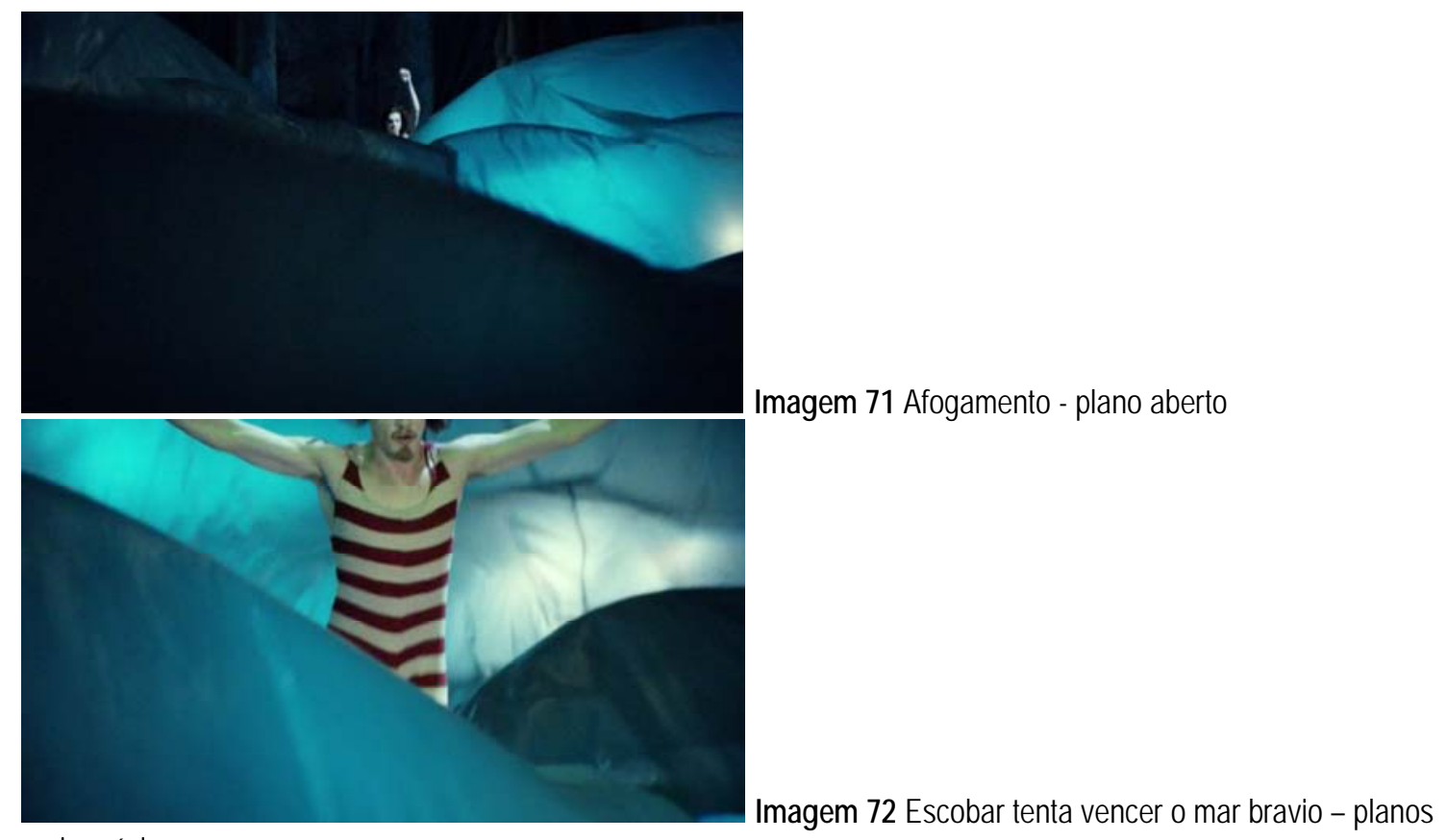

mais próximos

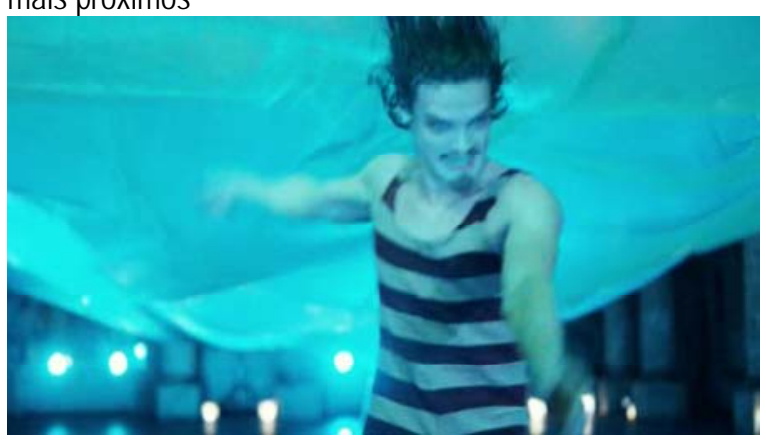

Imagem 73 Escobar começa a afundar - mudança de

iluminação

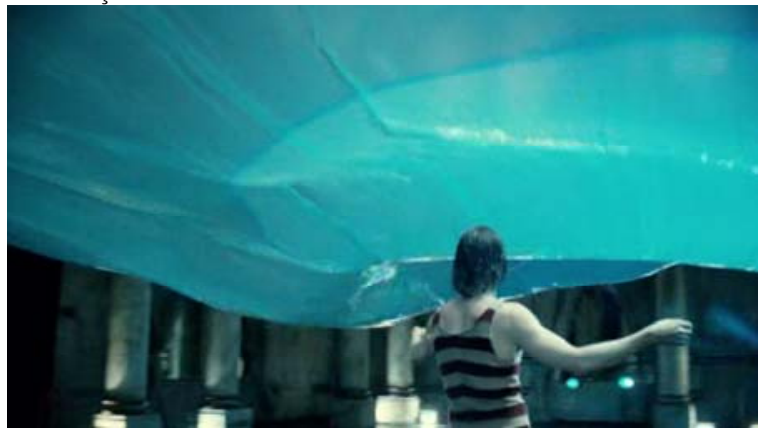

Imagem 74 Escobar desiste e afunda mais

O mar em que o personagem Escobar se afoga é composto por imensos plásticos agitados em torno do ator em cena e o conjunto todo é iluminado por um recurso de luz teatral que perpassa uma camada de água, projetando sobre o todo, reflexos da água em movimento. A influência do recurso usado por Fellini em alguns de seus filmes é clara, como pode-se perceber se relembrarmos alguns de seus cenários: 


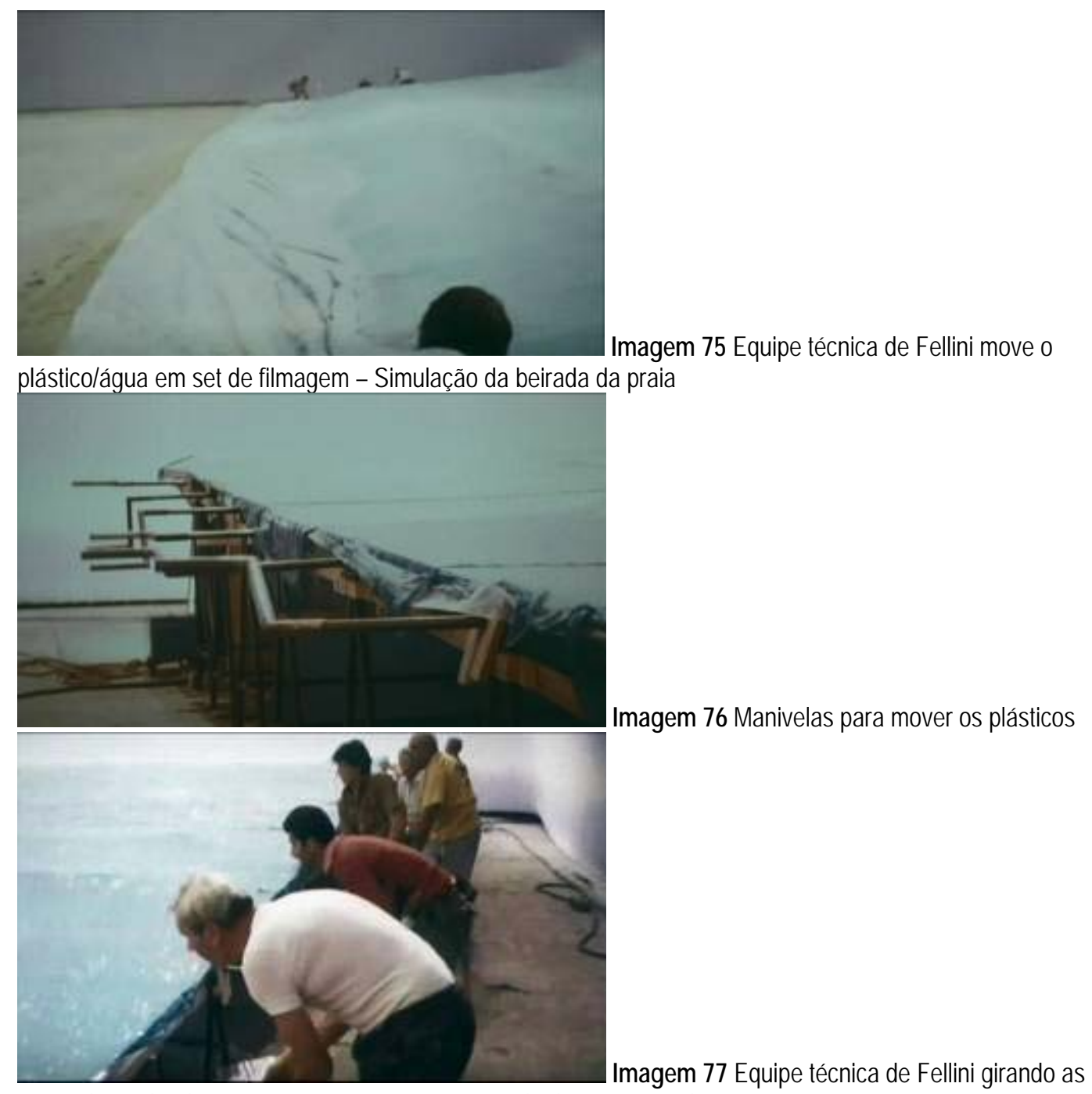

manivelas e dando movimento à parte mais profunda do mar - Set de E La Nave Va

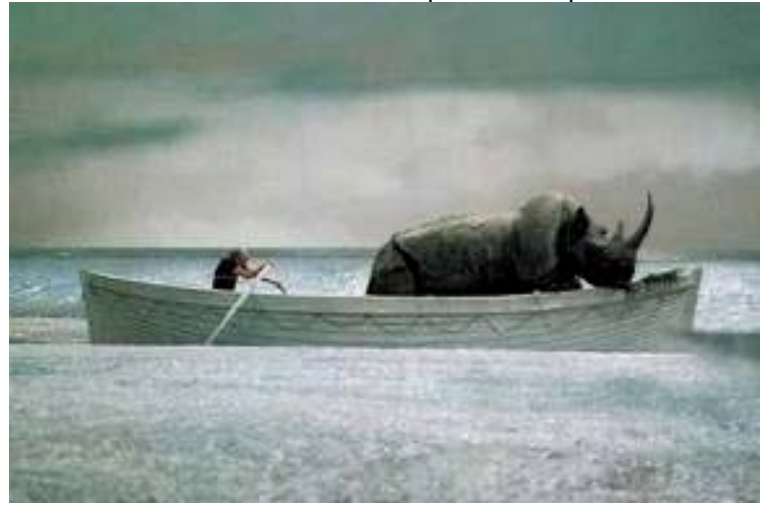

Imagem 78 Resultado visto no filme - barquinho inserido no mar falso

Valendo-se da mesma relação teatral com os cenários, o muro que separa os vizinhos Bentinho e Capitu foi todo desenhado em giz sobre o chão, totalmente pintado de preto como uma lousa de escola ${ }^{44}$. Os cavalos que os personagens montam em cena, ou os que puxam as carruagens possuem

\footnotetext{
${ }^{44}$ http://tvglobo.capitu.globo.com/capitu/category/oficinas/ - acessado em 30 de maio de 2010.
} 
apenas cabeças esculpidas de cavalo num corpo de bicicletas, muitos figurantes são feitos de xerox em papel (como nas cenas do início e do fim de Toby Dammit). Carvalho explicando suas escolhas cita uma frase de Machado de Assis: "A realidade é boa. O realismo é que não presta pra nada."

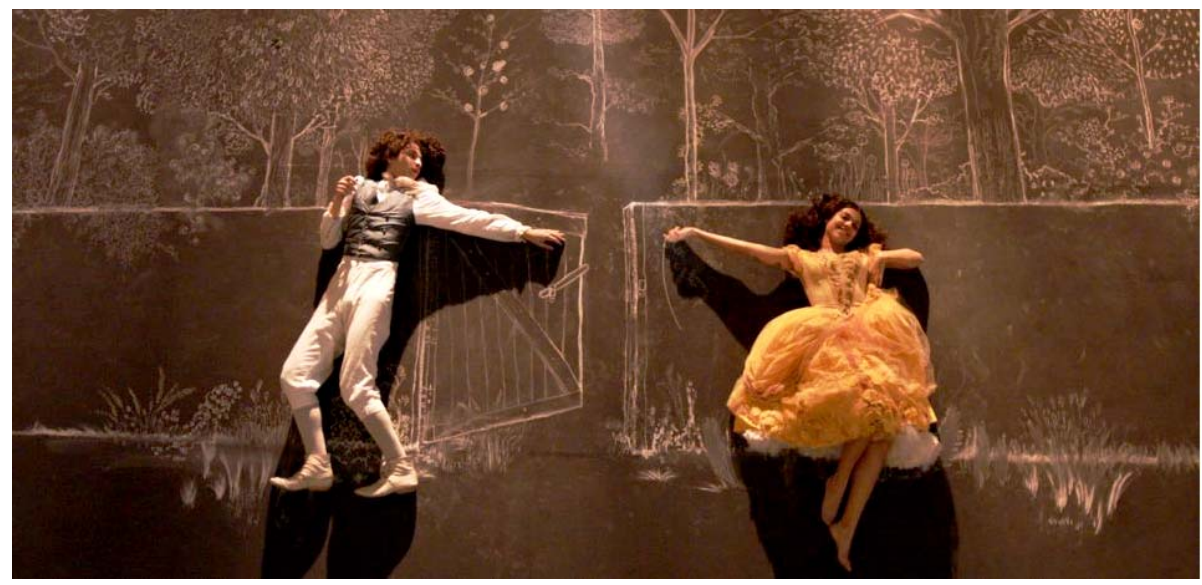

Imagem 79 Cenário desenhado no chão por equipe de Raimundo Rodriguez

Aproximando-se mais ainda de Fellini, no seu do modo de pensar o cinema pictoricamente, não deixando de incluir certos aspectos místicos, declara:

Minha motivação no cinema é a passagem de um estado a outro estado.

A cada instante preparar o espectador como um pintor escolhe e mistura suas cores, ou como um pagé reúne suas folhas para depois extrair delas um conjunto de sensações.

Só passamos de um estado a outro se este conjunto de sensações existir.

Só ultrapassamos a mera construção técnica de um filme se formos capazes de gerar uma fabulação, um sonho, com tamanha força de contaminar o escuro do cinema como uma peste.

É necessário criar um estado de vidência, de transformação, de imaginação.

Filmar é imaginar ao ponto de efetuar transformações sem fórmulas, sem modelos, sem clichês - principalmente! 
Imaginar ao ponto de encontrar uma imagem tal que já não seja possível distinguir o criador da criação, o ator do personagem, o cinema da vida ${ }^{45}$.

\section{APROXIMAÇÃO EQUIVOCADA - O CASO NINE}

Enquanto há inspirações tão genuínas, total ou parcialmente, no cinema de Fellini, pode-se encontrar vez ou outra quem queria homenagear o cineasta italiano e acabe cometendo um grande deslize. Este foi o caso do diretor americano Rob Marshall que recentemente filmou Nine (2009) inspirando-se no renomado Oito e meio (1963).

O filme acabou se assemelhando a um desfile videoclíptico de lindas mulheres. Mesmo sendo lindas e excelentes atrizes, afiguram-se como treinadas por um profissional da coreografia da música pop internacional nas cenas musicadas, ao estilo da cantora norte-mericana Beyoncé. Do desconforto dessa inadequação, surge uma lacuna aparentemente instransponível: fazer um filme do gênero musical homenageando Fellini sem a genialidade do maestro Nino Rota, marca registrada na trilha sonora de suas produções. As músicas dançantes são muito próximas de ritmos atuais.

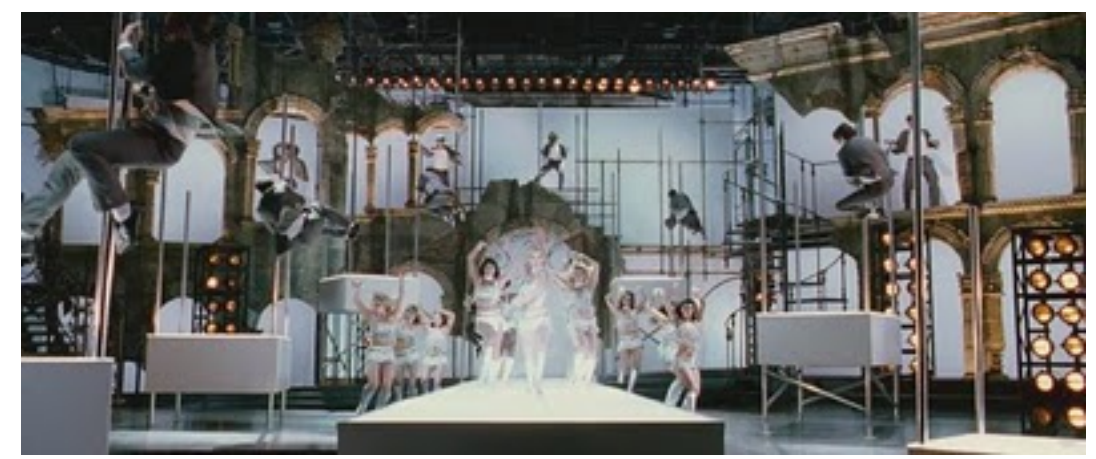

Imagem 80 Cena do musical Nine

Fellini possuía o dom de criar obras profundas, complexas, cheias de camadas interpretativas. Ainda assim, não soava pedante, agradava ao gosto popular. Não só por abordar assuntos que são do homem, universais, mas pelo contar leve, próximo e cômico, muitas vezes.

Não entender uma obra tão diversa quanto a de Fellini não é fato incomum. $\mathrm{O}$ tom de seus filmes muitas vezes não foi compreendido: foi tido

\footnotetext{
${ }^{45}$ http://www.lavouraarcaica.com.br/principal.html - Depoimento do diretor inserido no site oficial de seu longa-metragem Lavoura Arcaica. Acessado em 09 de junho de 2010.
} 
como exagerado, fora de propósito, às vezes até cafona. Mas isso justamente para aqueles que não se deixam envolver por histórias que não se contam na mesmice, que desconhecem a linguagem da poesia. Não se pode deixar de citar os muitos que hoje em dia nunca foram ao circo. Um ou outro vai ao teatro, mas não são a regra.

O filme de Marshall baseia-se em Oito e Meio (1963), nono trabalho do diretor italiano, estrelado por Marcello Mastroianni, Anouk Aimée e Sandra Milo. Nele, Guido Anselmi, o protagonista interpretado por Marcelo, é um cineasta que está a poucos dias de começar a rodar seu filme. Ele não consegue sequer escrever o roteiro e sofre todo tipo de cobrança de sua equipe até o impasse final. Em meio à perseguição sofrida por jornalistas, assistentes e produtores, a pressão aumenta com o confronto entre sua esposa e sua amante. Em Nine, salva-se a atuação brilhante do ótimo elenco escolhido para a película. Ainda que se fique com uma sensação bastante diferente da que se tem assistindo a Oito e Meio.

No original, quando tudo parece mesmo perdido, vemos a partir da aparição do mágico Snaporáz, os personagens da vida de Guido (considerado alter ego de Fellini), entrando em cena, num picadeiro, como os legítimos personagens que ele, desde o princípio, entendia fazerem parte de seu filme. Vê-se também, puxando a fila de personagens, alguns palhaços que tocam cornetas e um menino - que, não por acaso, é o regente/diretor do show e o último a sair de quadro, quando as luzes se apagam. Isto é o circo! Esta é a metáfora do cinema de Fellini, e da confusão que sinceramente se confessa (em imagem e texto nesta cena), com uma pureza infantil até, na maneira de contar a sua visão do mundo e na sua maneira de vivenciá-lo. Há uma atmosfera absolutamente onírica e não sabemos se ele, Guido, voltou atrás e realizou, ou não, o filme afinal de contas. Mas isso não é o mais importante. Sabemos que idealmente ele realizou - tudo o que ele buscava traduzir em imagem durante todo o filme é dito com esta cena final. 


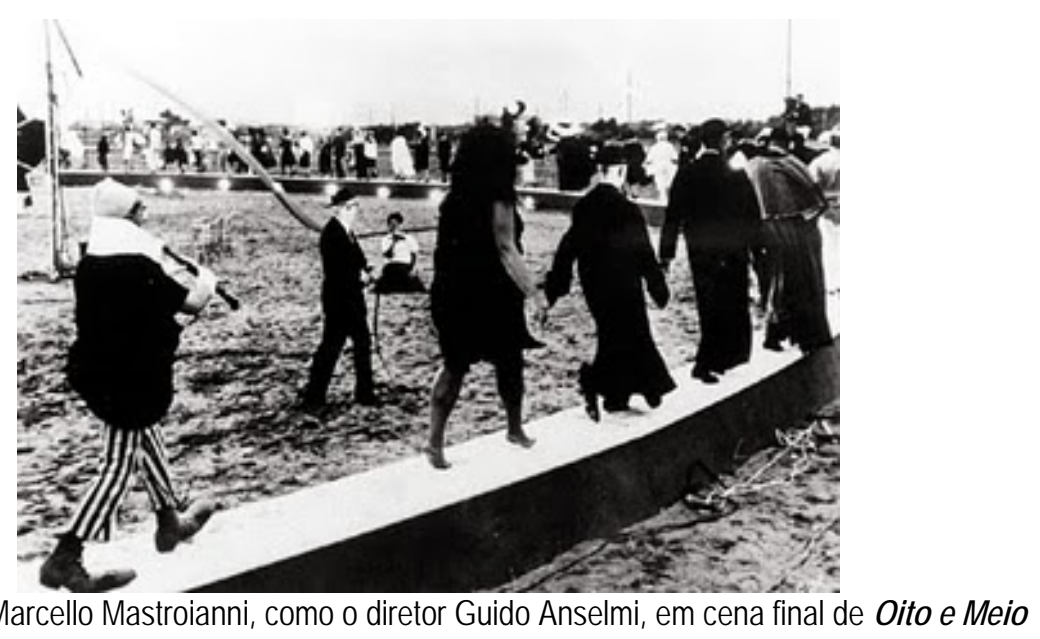

Imagem 81 Marcello Mastroianni, como o diretor Guido Anselmi, em cena final de Oito e Meio

Rob Marshall se esforça em manter este clima quando coloca na última sequência, com Guido em estúdio, a entrada inesperada e triunfal de todos os personagens anteriormente apresentados no filme. Na proposta de Marshall, eles posam como dançarinos da Brodway, não têm a simplicidade genuína do circense, a simplicidade intentada pelo diretor de Oito e Meio. A figura do menino (o ímpeto rebelde, impulsivo e criativo) também está presente e talvez seja a melhor de todas as referências feitas ao original.

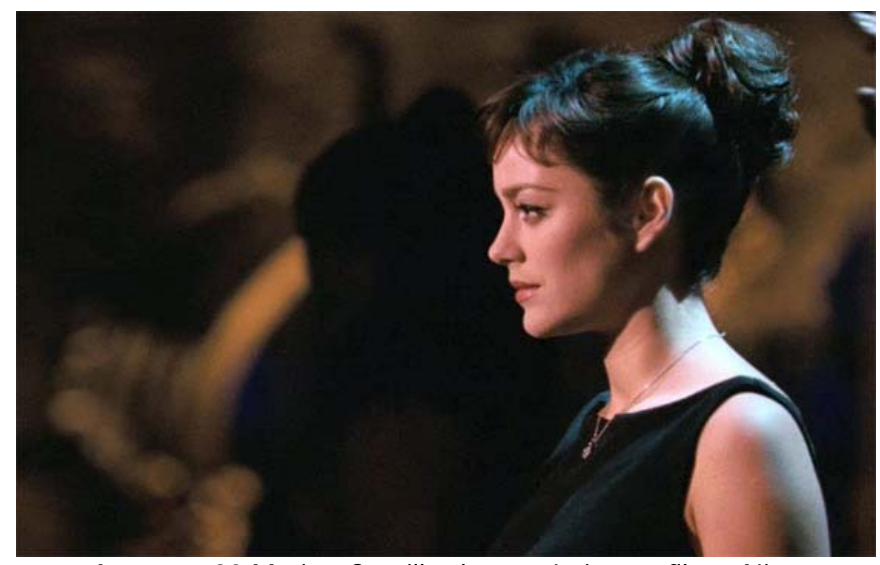

Imagem 82 Marion Coutillard como Luisa no filme Nine

O papel da esposa de Guido desempenhado por Marion Coutillard, antes interpretado por Anouk Aimée, é digno, forte, contundente, mas tendencioso ao tentar misturar vida e obra de Fellini - Giulietta Masina e Luisa Acari, respectivamente - de forma leviana, o que além de tudo não existe no primeiro filme. A Luísa de Nine (diferentemente da de Oito e Meio, que embora mantenha postura crítica, não nos dá subsídios para identificá-la profissionalmente), é parceira criativa de Guido (como Giulietta era de Federico), consultada para tudo e respeitada criativamente, inclusive pela equipe. Ela não só é atriz, como é também estrela do filme que lança a carreira 
do marido, Guido - referência explícita ao filme La Strada e aos filmes da primeira fase de Fellini.

A crise do casal nas duas versões também parece diferente. Em Nine, desapercebidamente o diretor age como um sedutor barato com todas as atrizes do teste, de maneira igual. Assim, sua esposa, como uma de suas atrizes mais antigas, reconhece neste teste a mesma fala, o mesmo gesto, a mesma sedução antes dirigida a ela quando se conheceram, trabalhando juntos, e que ela julgava ter sido única e especial. Aqui o que fere é a banalização do gesto e do sentimento. A "traição", assim, é vista, e seu prolongamento é sugerido, a partir da banalização desse gesto de carinho e admiração.

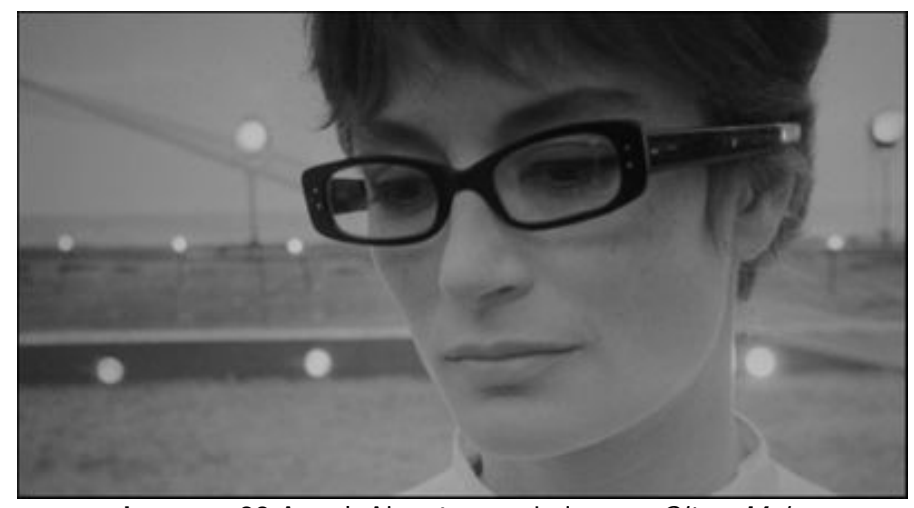

Imagem 83 Anouk Aimeé como Luisa em Oito e Meio

Em Oito e Meio a esposa se magoa com a exposição da intimidade do casamento e da deterioração da relação. O diretor aqui quer colocar na película suas angústias pessoais, as questões de sua vida privada, material humano a ser trabalhado pelo cinema. Importa muito pouco a relação do diretor com as várias atrizes em si, mas, sim, o papel que elas representam em cena - uma delas, "a esposa" e todas as outras, "a amante". Aqui "a traição" é encenada e reconhecemos os personagens da esposa e da amante por seus figurinos, códigos pré-definidos: a roupa espalhafatosa de uma e os óculos intelectuais da outra. 


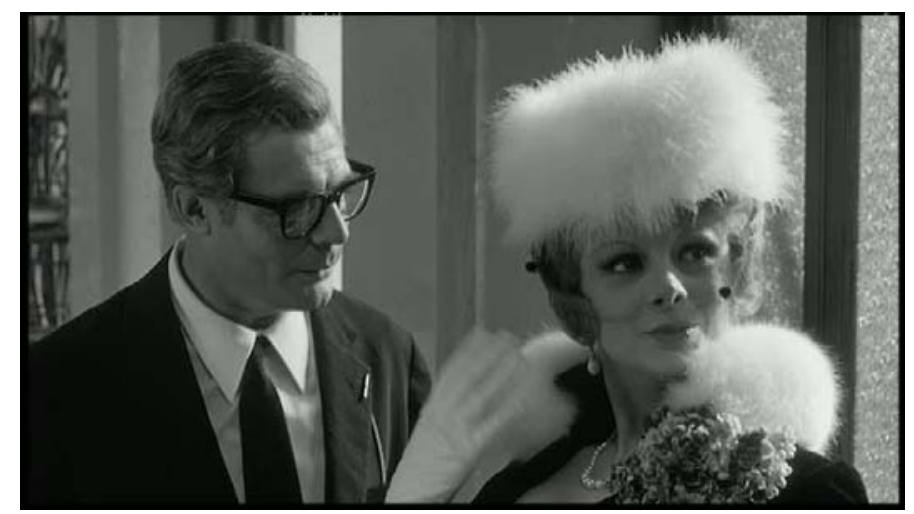

Imagem 84 Sandra Milo, interpretando Carla, a amante, em seu figurino espalhafatoso

O papel de Nicole Kidman corresponde ao de Cláudia Cardinale, mas, ao mesmo tempo, tenta remontar ao de Anita Ekberg em La Dolce Vita (1960), sem, no entanto, igualar-se em magia ou glamour.

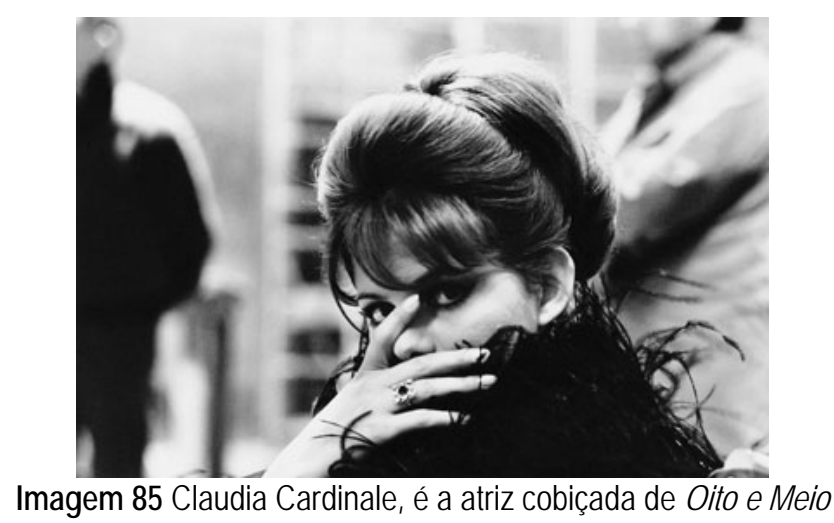

Não há problema com a excelente atuação de Nicole, mas a cena, embora bem elaborada, não é lírica, e seu personagem não alcança a estatura de mito que o de Anita parece alcançar sem nenhum esforço. No texto, o personagem de Nicole prefere estar na pele do homem, quer sair do pedestal que confere às musas o caráter indefectível. É mais realista.
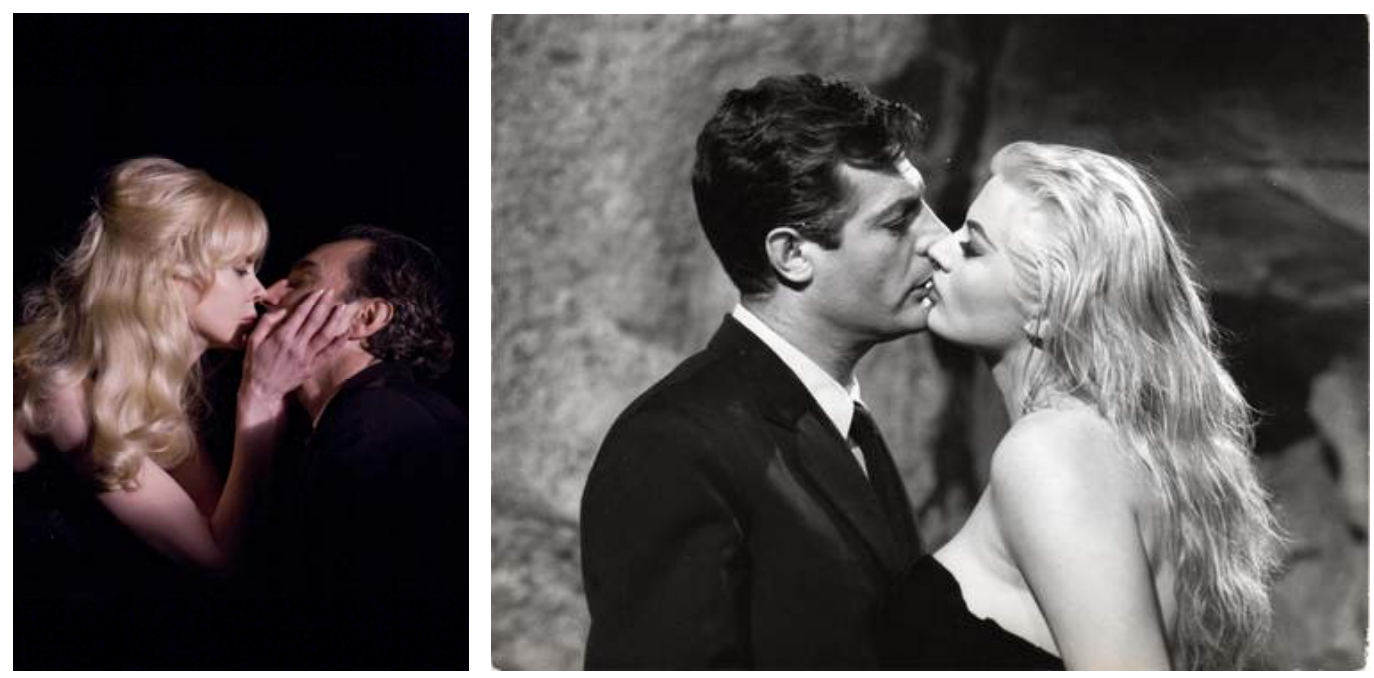
Imagem 86 Nicole Kidman fazendo o papel da atriz cobiçada em Nine - influência clara da diva Anita Ekberg Imagem 87 Anita Ekberg, diva do filme La Dolce Vita de Fellini

A amante, antes interpretada por Sandra Milo, agora aparece na pele de Penélope Cruz. Suas cenas são bastante parecidas, desconsiderando a cena musicada em que Penélope dança. A atriz espanhola também tem ótima atuação, mas seu papel aparece com menor profundidade. Não se sabe nada de sua família (a não ser que tem um marido para o qual não dá importância). Vemos dela apenas sua paixão obsessiva por Guido, tentando até o suicídio para chamar sua atenção.
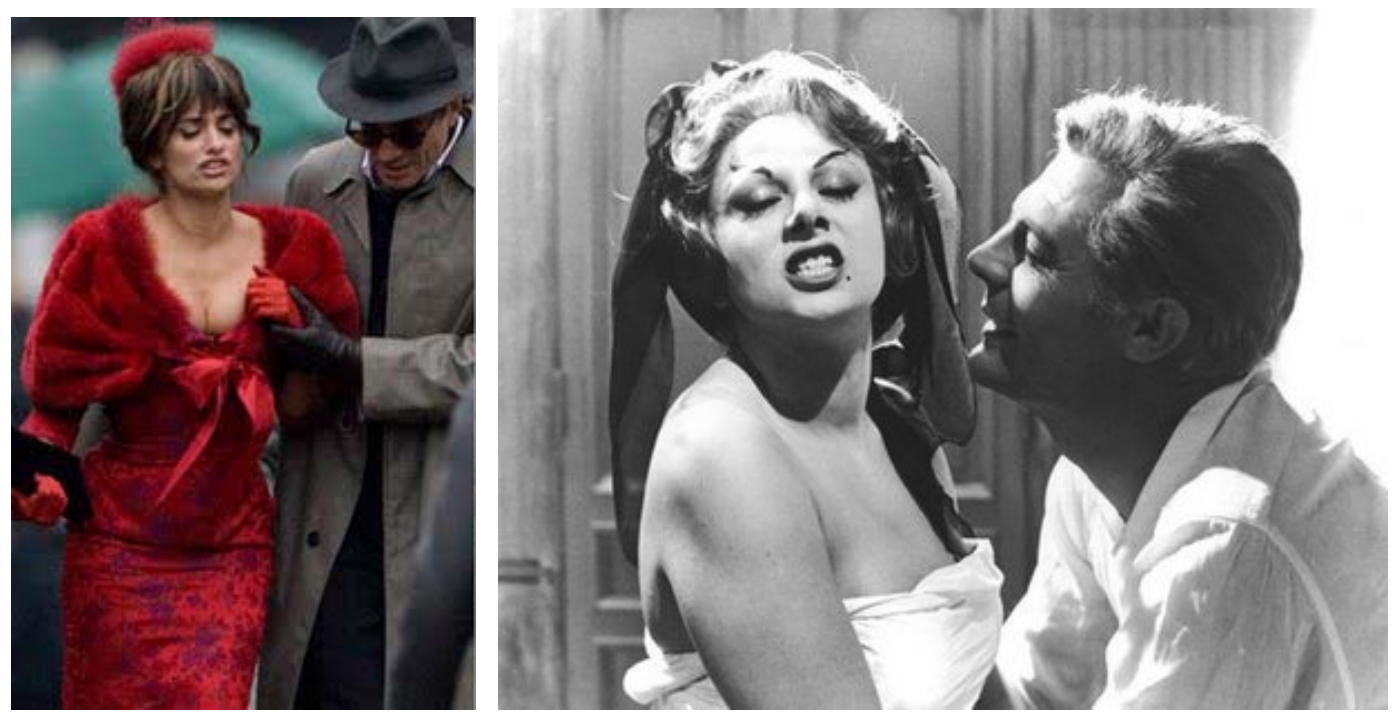

Imagem 88 Penélope Cruz como a amante, Carla, em cena da chegada da estação.

Imagem 89 Sandra Milo, em cena que foi refilmada de maneira quase idêntica em Nine.

A mãe e o pai do cineasta em Oito e Meio são velhos e o pai tem seu destaque - após uma conversa, Guido o ajuda a entrar num buraco e em seguida despede-se da mãe num beijo confuso, que de materno se torna passional (além da figura da mãe se transformar nessa cena, na da esposa).
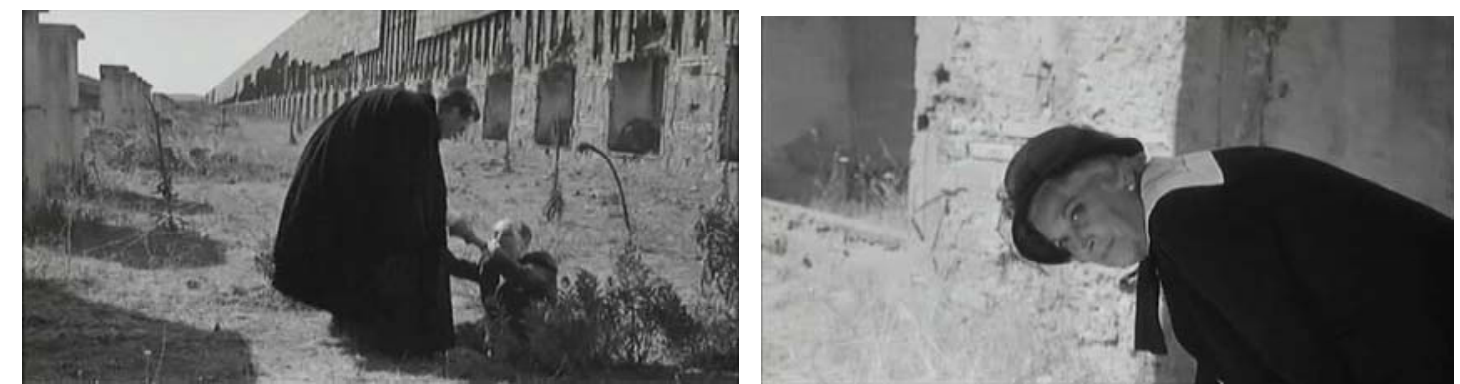

Imagens 90 e 91 Os personagens pai e mãe de Guido no filme Oito e Meio 


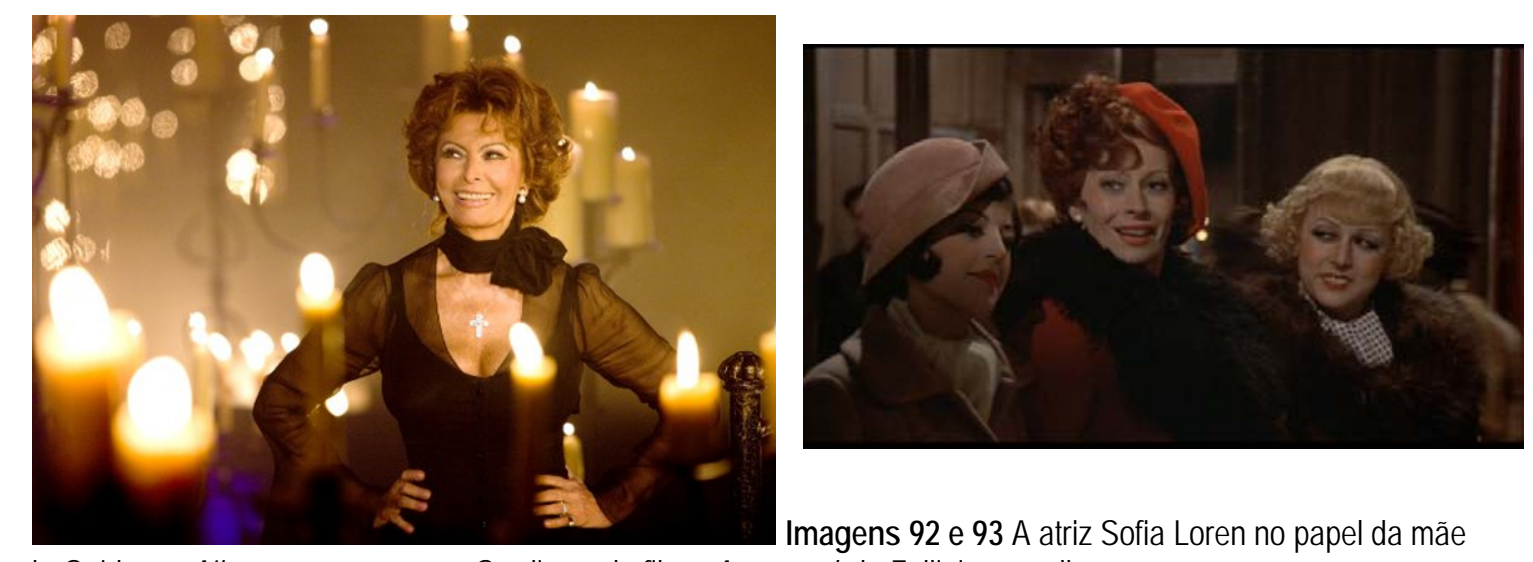

de Guido em Nine e o personagem Gradisca, do filme Amarcord, de Fellini - semelhança

Em Nine, o personagem do pai é omitido e a mãe de Guido é atraente interpretada não por uma senhora qualquer, mas por Sophia Loren. Seu personagem, imageticamente, lembra muito um personagem feminino de Amarcord (1973), uma mulher bonita chamada Grasdisca, freqüentadora do cinema e da qual todos os meninos queriam se aproximar na sala escura para tirar algum proveito. A senhora mais maternal do filme é a figurinista Eleonora / Lili, interpretada pela genial Judi Dench, que, no original, tem uma passagem ínfima em uma das cenas. Lili funciona um pouco como a consciência de Guido, completamente desgovernado, à beira de um ataque de nervos durante quase todo o filme. $\mathrm{O}$ abismo de se realizar um filme, em uma obra e depois na outra, parece se distinguir. O Guido Anselmi interpretado por Mastroianni parece preocupado em dizer algo simples, mas importante. Já o Guido Contini interpretado por Jerry Lee Lewis, a julgar pelo conjunto da película, parece preocupado em dizer alguma coisa, mas de modo grandioso.

Completando o hall das mulheres escolhidas, há também Saraghina, a prostituta. Trata-se não apenas de uma figura grotesca - Saraghina era feia e gorda - como também mítica, representando, para aqueles meninos italianos, o sexo, a fertilidade, a abundância. Não por acaso, esse personagem residia junto ao mar. Na versão americana, Saraghina, interpretada pela cantora pop Fergie, não é nem grotesca, nem feia, nem gorda. Muito ao contrário, é retratada como uma sensual devoradora de homens, perigosa. Sua dança na areia na versão original era mais ingênua, até um pouco cômica. Na versão atual, é estudada para seduzir, coreografada - como nos clipes musicais que exibem essas "musas po(p)asteurizadas" atuais. 

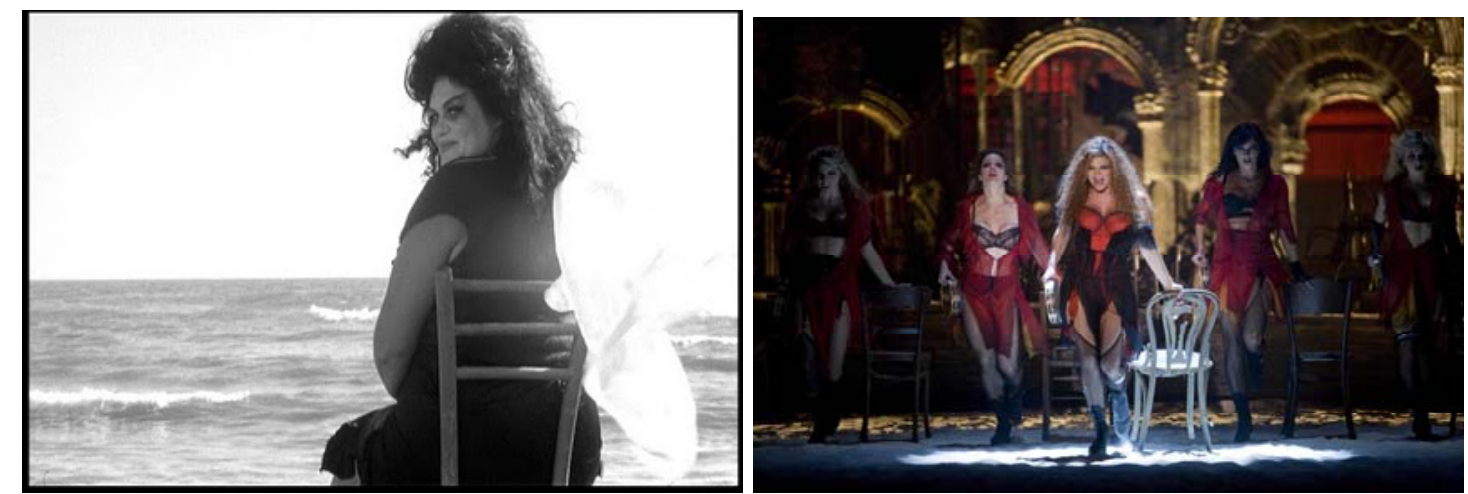

Imagem 94 A atriz Eddra Gale como Saraghina no filme Oito e Meio

Imagem 95 A cantora Fergie interpretando o mesmo personagem no musical de Marshall

Outros personagens de Oito e Meio, assim como algumas figuras muito presentes na obra felliniana, não foram considerados nesta homenagem. Sente-se falta do circo no filme de Rob Marshall. Nele, o espetáculo ficou por conta de um cabaré-meio-Brodway, onde as ruínas de Roma, no cenário ao fundo, são mero enfeite. Talvez, para tentar lembrar que se queria homenagear um cineasta italiano...

Pode-se entender porque Marshall tenha escolhido Oito e Meio para fazer a sua releitura e homenagem a Fellini, por ser um dos filmes mais apontados como auto-biográficos do diretor. Mas na tentativa de explicar o que Fellini apenas sugere e deixa no ar para sentirmos, acaba com sua poesia característica e corre o sério risco de interpretar mal aquilo de simples que Fellini gostaria de dizer.

Algumas transformações sofridas na "transposição" de Oito e Meio para Nine, justificam-se na tentativa de dar uma roupagem nova ao filme, imprimir um novo ritmo, mais rápido, ágil, na tentativa de atualizá-lo. Talvez Marshall quisesse seduzir um público mais jovem, que não viveu o período do cinema de Fellini para apresentar o cineasta italiano a esta geração. Imbuído desta intenção utilizou ícones da música pop ou do próprio cinema para chamar sua atenção, ao invés de confiar na força indubitável das imagens construídas com poesia. (Afinal, o que dizer do sucesso de público alcançado por Tim Burton, Jean-Pierre Jeunet e Luiz Fernando Carvalho?)

A tentativa, em análise geral, gerou um resultado que se sobrepõe à obra felliniana, pela imposição da linguagem dos musicais, de um universo coreografado. O que se deseja com este filme - ou se espera - é que este seja 
apenas mais um ponto de vista da cultura norte-americana sobre Fellini e sua obra.

\section{Considerações finais}

O que podemos observar de todas estas aproximações e influências (confessas ou inconfessas) de Fellini é que, embora haja devios, como Nine, trabalhos inspirados em um cinema mais comprometido com uma criação poética e mais desprendido de representações realistas, podem atingir-nos de maneira contundente.

Trabalhos como os de Tim Burton, Jean-Pierre Jeunet, Guillermo Del Toro e Luis Fernando Carvalho são absolutamente diferenciados no mercado cinematográfico e têm ganhado destaque entre o público e a crítica - o que é a reconhecimento da boa aceitação para um diretor.

Em suas obras há espaço para a fabulação, sem medo que não sejam aceitas dentro do padrão realista mais inteligível para a maior parte das pessoas. Estas obras vão além, atingem as pessoas pelas metáforas que proporcionam, fazem com que cada espectador estenda os significados apreendidos para o campo de sua vida, seu próprio mundo. São filmes que "fisgam" o espectador pelas emoções e pelas sensações proporcionadas pelas imagens e pela música - filmes sentidos, como explica Burton retomando e comparando o estilo de seus filmes aos de Fellini.

Todos eles têm em comum o gosto por contar histórias que abordem temas universais, que nos interessem enquanto seres humanos. E contam essas histórias de modo diferente, talvez até por isso nos façam entrar mais ainda em seus espaços diegéticos. Há um jogo estabelecido com o público, um pacto, como no teatro. Basta que nós, espectadores, entremos nesse jogo e aceitemos as regras ditadas por quem o inventou, o diretor. A partir de então, 0 que se dá, é uma leitura desse novo mundo criado, a re-significação das coisas, o que muitas vezes se dá a partir da sensação.

Cabe aqui também a dimensão do ritual, do sagrado, que o universo do teatro compreende muito bem, mas que o universo do cinema parece ter 
renegado com o tempo. Toda a magia ficou a cargo dos equipamentos de última geração, mais na intenção de demonstrar sua excelência do que de alcançar novas possibilidades de re-significar as coisas, geralmente. Assim, a magia foi posta em um lugar externo ao suporte humano. Estes diretores me parecem voltar à dimensão humana, ainda que contem com uma direção de arte grandiosa, e às vezes até com recursos de pós-produção, ela vem de encontro à emoção, ao sentimento, sem em nenhum momento afastar-se disso. Logo, certo misticismo que encontro em Fellini e certa fé no mundo que se cria (nas "mentiras" inventadas e contadas) encontro também em Eisenstein, em Poe, em Burton, em Jeunet, em Del Toro e em Carvalho.

As obras apontadas são filmes em que as imagens foram meticulosamente compostas, segundo intenções muito específicas, gerando diversas camadas de interpretação possíveis para a película, sempre mais profundas e complexas.

Podem não haver cineastas que se equiparem à genialidade de Federico Fellini, mas seu modo de contar histórias ficou impresso na história do cinema e é inegável que influencie todos aqueles que suspeitem da força que as imagens podem ter.

A pesquisa A Construção Plástica dos Personagens Cinematográficos: Uma investigação feita a partir da obra de Federico Fellini investiga o processo de composição de personagens e o caráter fundamental dos recursos plásticos para que isto se dê de modo completo. Considerando a relevância do bom uso destes recursos, a pesquisa conclui sobre o importante papel desempenhado pela direção de arte na confecção de um filme. A meta para quem trabalha na realização de uma obra cinematográfica deveria ser alcançada quando se consegue ser mais fiel às idéias que se pretende transmitir do que a reproduções realistas.

Os personagens precisam se revelar com clareza, força, empatia, fluidez, e o ponto de vista desse personagem será construído a partir dos recursos visuais disponíveis no cinema. Sabe-se que são muitos, mas, o cenário e o figurino, por identificarem mais facilmente o personagem, são os responsáveis mais diretos por darem a medida das sensações, opiniões e postura deste personagem. É necessário construir essas identidades com 
todos os recursos de que dispomos, sem limitações. É o que nos aponta a construção de personagens feita por Fellini.

Sou uma profissional atuante no meio teatral e principalmente cinematográfico, em cenografia e figurino. Meus conhecimentos adquiridos no exercício das atividades profissionais de caráter prático me levaram a entender e avaliar muito melhor os conhecimentos científicos obtidos com a pesquisa até o presente momento. Estar aberta a integrar estas duas qualidades de conhecimentos tornou minha observação muito mais contundente.

Posso dizer que em nosso país, os filmes vem sendo realizados muito mais sob o prisma das construções realistas, do que das construções imaginárias. Prioriza-se, na composição dos cenários e dos figurinos, muito mais a cópia fiel do que se pode ver nas ruas, à elaboração de atmosferas, à materialização de humores da personagem, idéias ou a representação plástica de sua dada personalidade, salvo uma ou outra rara e maravilhosa exceção, como é o caso de Carvalho.

Compreendi e absorvi o modo como Fellini iniciava seu processo criativo antes de realizar um filme. E recentemente pude testá-lo numa peça teatral de rua $^{46}$ sobre a vida e a obra do poeta mato-grossense Manoel de Barros, para a qual fui convidada a fazer a direção de arte. Testei este processo criativo na concepção de figurinos e adereços para os personagens, que eram quase todos alegóricos. Conforme imaginava e entendia a natureza de cada um dos personagens, desenhava-os e tentava traduzir através de formas, cores, texturas e volumes em seus figurinos e adereços, aspectos importantes de cada um deles.

\footnotetext{
${ }^{46}$ Espetáculo teatral para rua intitulado Ruas de Barros, direção e dramaturgização Frederico Foroni, direção de arte Carolina Bassi, direção musical Marcus Siqueira. Elenco: Melina Anthis, Paulo Willians, Iris Yasbek e Antônia Mattos.
} 


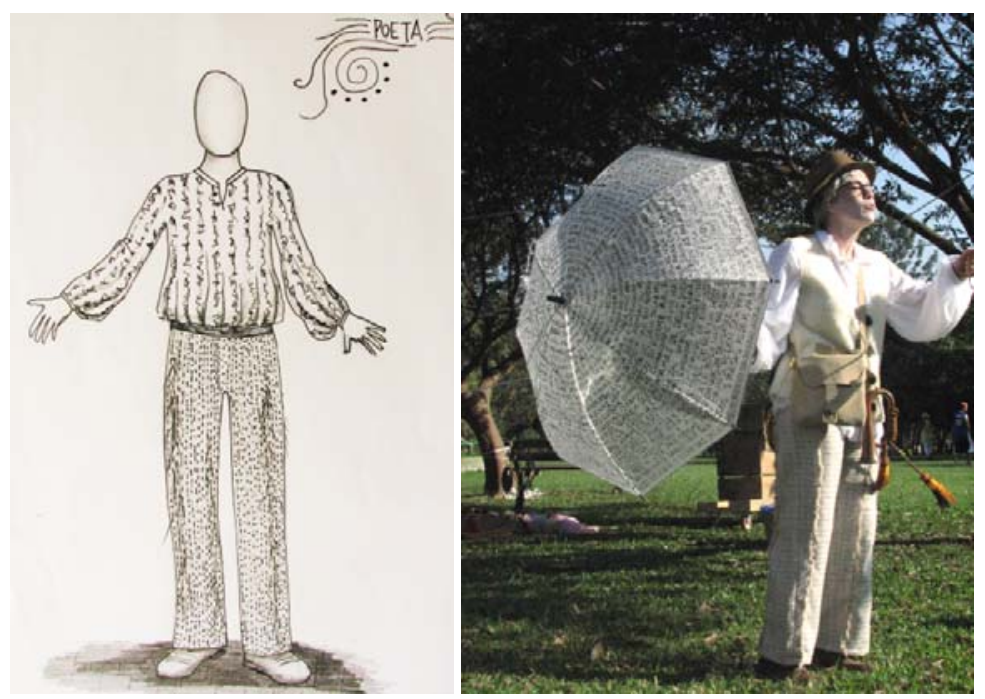

Imagem 96 Desenho feito por mim para o personagem Poeta

Imagem 97 Atriz Melina Anthis interpretando o Poeta (foto Carolina Bassi)
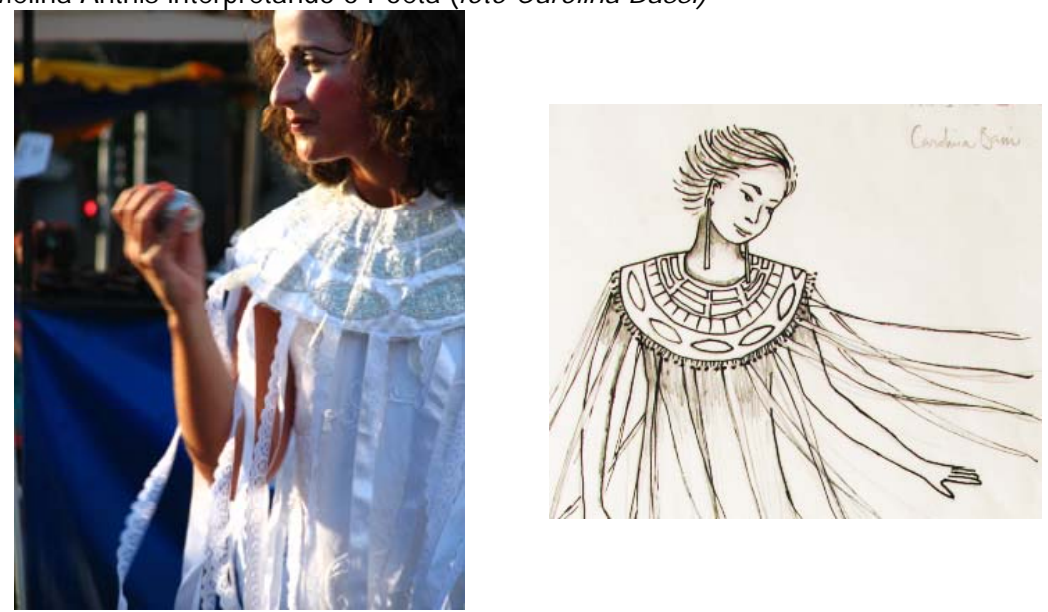

Imagem 98 Atriz Iris Yasbek interpretando a Anima (foto Carolina Bassi)

Imagem 99 Desenho feito por mim para o personagem Anima
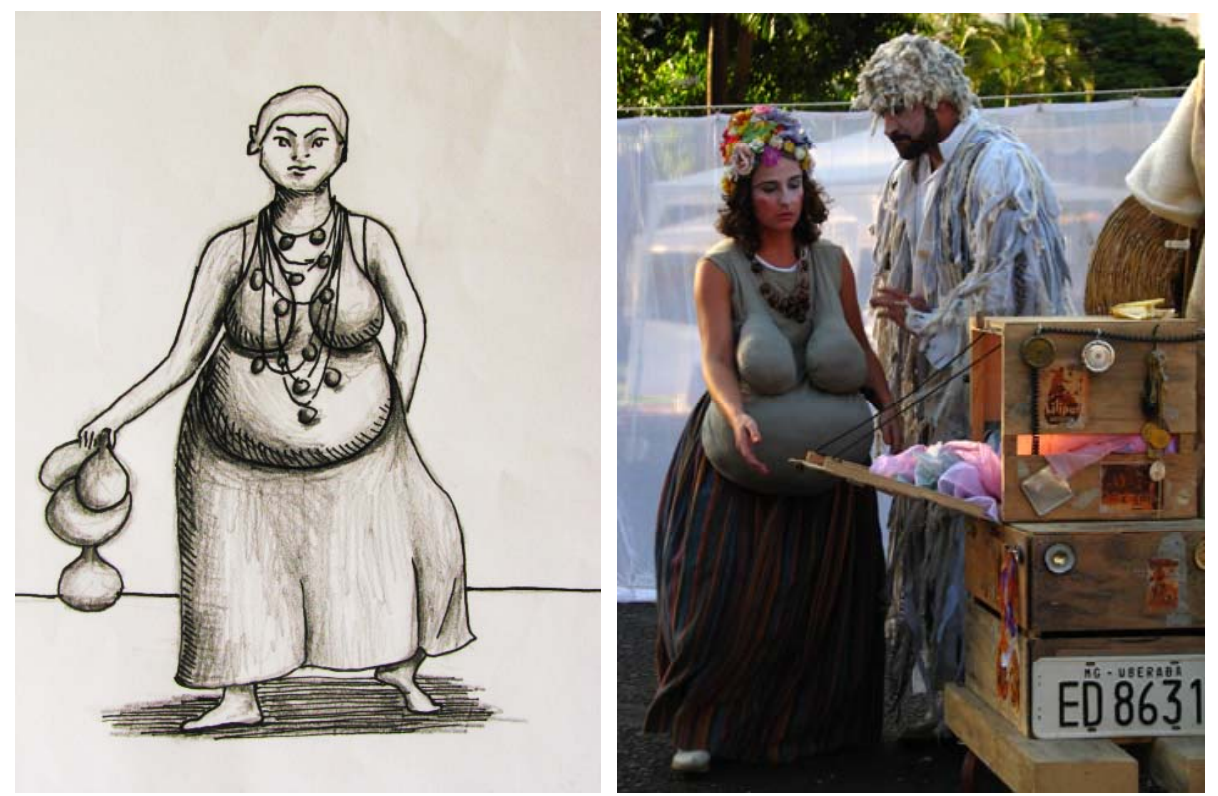

Imagem 100 Desenho feito por mim para o personagem D. Maria

Imagem 101 Atriz Iris Yasbek interpretando o Poeta (foto Carolina Bassi) 

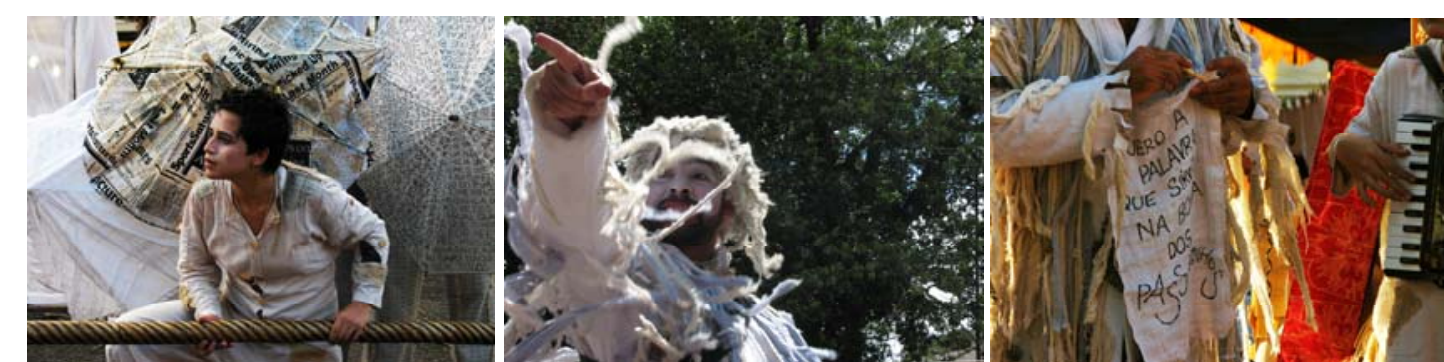

Imagens 102, 103 e 104 Antônia Mattos e Paulo Willians em cenas de Ruas de Barros (fotos Carolina Bassi)

Quando se faz teatro, este processo criativo se dá mais tranquilamente, pois há mais liberdade para trabalhar com resultados plásticos interessantes e menos realistas - tanto na direção de arte quanto em toda a encenação. Quando se trabalha com cinema, pensar a plasticidade de maneira livre se torna muito mais difícil.

Os motivos são diversos. Um deles é a preocupação com a aceitação do público, porque não havendo aceitação, o filme não faz sucesso, fica menos tempo em cartaz, rende menos bilheteria e corre o risco de não dar lucro suficiente a quem produziu ou não se pagar. Mas é comum subestimar a inteligência e o gosto do público considerando que não entenderá ou não se identificará com a obra, se esta não for realista.

Outro motivo para a falta de ousadia plástica, que também envolve a questão financeira, é o custo da filmagem em estúdio. Podemos considerar que construir cenários custa, em geral, muito mais do que filmar em locações estas sendo usadas como estão ou sofrendo interferências da direção de arte. Isto porque a equipe especializada de cenotécnicos é muito maior, trabalha durante um período muito maior de tempo; desde que os cenários são levantados estruturalmente até receberem o acabamento fino.

Se o tempo de construção dos cenários é maior, sabe-se que o tempo de concepção também é maior, porque é necessário desenvolver um projeto arquitetônico antes. Além de todo o processo de pesquisa de referência para os cenários, figurinos e maquiagem, que precisa constituir a primeira etapa de trabalho e necessita de tempo para ser bem realizada. No entanto, o que mais se vê hoje em dia, por medida de redução de gastos, são prazos de preparação cada vez mais enxutos e equipes cada vez mais sobrecarregadas.

Outra razão ainda é que os próprios profissionais de cinema estão habituados a trabalhar os filmes realisticamente. Sem dúvida que há muita beleza num cenário construído com realidade, cheio de vida! Chegamos a 
acreditar, como espectadores, que o personagem vive ali há tantos anos. $\mathrm{E}$ para isso há um requinte de detalhes impressionante: dentro das gavetas do cenário de uma cozinha há talheres condizentes com aquele personagem, seu meio social e sua época, na geladeira há comida de verdade, há xampu começado no banheiro, há dinheiro "cenográfico" e pequenas anotações nas carteiras, por exemplo.

Mas o ponto é que não precisamos estar restritos a uma reprodução integral da realidade apenas, limitados a isto como uma regra. Abrir mão de uma criação plástica mais criativa ao realizar um filme é perder quase todo o seu campo de significação poético, que é muito importante para o cinema enquanto arte.

As equipes de cinema estão acostumadas a restituir a realidade nos filmes, mas enfrenta-se também a dificuldade de estar submetido às decisões de uma direção realista. Como já dito, temos enquanto equipe que perseguir todos a mesma idéia, o mesmo propósito, o qual é dado pelo diretor. Portanto, para desenvolver um tipo de cinema como o de Fellini, com o de Burton, Jeunet, Del Toro, Carvalho, é necessário que o diretor opte por essa direção em primeiro lugar - o que é muito difícil.

Em virtude disto, nem sempre é possível empregar em minhas concepções de direção de arte esse tipo de visão, não realista e plástica. A menos que eu me torne, eu mesma, a diretora de cinema a sugerir este tipo de estética narrativa.

Espero com esta pesquisa ter fornecido mais ferramentas de análise aos críticos e pesquisadores da área, de modo que possam desfolhar todas as camadas interpretativas que uma grande obra fornece quando a olhamos mais de perto. E espero também que criadores de cinema, de todos os departamentos, possam sentir-se mais livres em seus processos criativos e inspirados a realizarem outros tipos de filme, como eu. De Fellini, empresto algumas palavras com as quais me identifico:

Acredito que o que mais me interessa é a liberdade do homem, a libertação de cada homem das trevas, das redes, dos convencionalismos morais e sociais em que acredita, ou melhor, em que pensa acreditar e que o angustiam, o limitam, 
fazem-no parecer menor, e até mais malvado. Se quiserem colocar-me uma bandeira, uma bandeira pedagógica, resumam-na neste lema: ser o que se é, quer dizer, descobrirmo-nos a nós mesmos para poder amar a vida. A vida para mim, com todas as suas dores e tragédias, é bela, me agrada, me diverte, me comove. Faço o possível para que os demais possam compartilhar meu modo e sentir. (STRICH; KEEL, 1983, p. 137) 


\section{REFERÊNCIAS}

\section{1 - Federico Fellini}

\section{Escrito sobre Fellini:}

ALPERT, Hollis. Fellini, a life. New York: Atheneum, 1986

BETTI, L.et al. Ter passi nel Delírio. Capeli: Bologna, 1968.

BORIN, Fabrizio, MELE, Carla. Federico Fellini. Rome: Gremese Editore, 1999.

BURKE, Frank. Federico Fellini: Variety Lights to La Dolce Vita. London:

Columbus Books, 1984.

CALIL, Carlos Augusto. "Caminhos do mestre Federico Fellini" (depoimento a Alessandro Gianinni). Artigo de jornal publicado por Jornal da Tarde São Paulo, p.12a, 26/nov/1994.

. (org.) Fellini Visionário. São Paulo: Companhia das Letras, 1994.

CINEMATECA BRASILEIRA, Cinema Italiano. São Paulo, 1960.

CHANDLER, Charlotte. Eu, Fellini. São Paulo: Record, 1986.

DE SANTI, P. Marco. I Disegni di Fellini. Laterza, 2004.

DE SANTI, P. Marco. Federico Fellini: dai disegni ai film. Pisa: Edizioni Giardini, 1989.

DIAS, Maurício Santana, trad. "A Obra Prima Fantasma". Artigo do jornal La Repubblica, republicado por A Folha de São Paulo. Mais! São Paulo, 05/mar/2006.

FABRIS, Mariarosaria. "Federico Fellini: quase um auto retrato". Artigo de jornal publicado por O Estado de São Paulo, Caderno 2/Cultura São Paulo,

10/out/2004, p.6.

GRAZZINNI, Giovanni. Algún dia haré um bela história de amor:

conversaciones con Federico Fellini. Barcelona: Gedisa, 1985.

KEZICH, Túlio. Fellini: uma biografia. Porto Alegre: L\&PM, 1992.

MARTINS, Luiz Renato. Conflito e Interpretação em Fellini. São Paulo: Edusp, 1994.

MOLLICA, Vincenzo. Fellini! Random House Inc, 2004.

Fellini: Words and Drawings. Trans. Nina Marino. Welland, Ontario:

Editions Soleil, 2001.

. Scenari. Il fumetto e il cinema di Fellini. Editore Del Grifo Itália, 1984.

PETTIGREW, Damian. Eu sou um grande mentiroso. Rio de Janeiro, Ed. Nova Fronteira, 1995.

ROHDIE, Sam. Fellini Lexicon. London: The Cromwell Press, 2002.

SALACHAS, Gilbert. Federico Fellini. Paris: Seghers, 1963.

SOUZA, Gilda de Mello e. "Fellini e decadência". Artigo de periódico publicado por Discurso São Paulo, p.175-178, v.1, n.2. São Paulo, 1971

TORNABUONI, Lietta. Federico Fellini. New York: Rizzoli Internacional

Publications, 1995

\section{Escrito por Fellini:}

FELLINI, Federico. "Fellini nega que seus filmes sejam autobiográficos e diz inventar a vida". Entrevista ao jornal El País, republicada por Folha de São Paulo, São Paulo, 28/jan/1990, pp. E-1, E-2.

Fellini por Fellini. Edição de Christian Strich e Anna Keel. Trad. de J. A. Pinheiro Machado, Paulo Hecker Filho e Zilá Bernd, Porto Alegre, L\&PM, 1983. 
Fazer um Filme. São Paulo: RCB, 2000.

Fellini!.New York: Thames \& Hudson, 2003

Fellini: I Costumi e le Mode. Milano: Charta, 1994.

Il mestiere de regista. Intervista con Federico Fellini / Rita Círio. Milano:

Garzanti, 1994.

, Manara M.: El viaje de G. Mastorna traduzione dall'italiano di Juanjo

Sarto. Barcellona: Ediciones B, 1996.

Entrevista sobre cinema realizada por Giovanni Grazzini. Rio de

Janeiro: Civilização Brasileira, 1986.

Films: les quatre cents plus belles photographies dês quinze films.

Paris: Albin Michel, 1979.

Filmes que nunca veremos. Victor Sagi Servicios Editoriales: Ayma,

1978.

Conversations with Fellini. Edited by Constanzo Contantini. San Diego;

New York: Harcourt Brace \& Company, 1996.

Fellini / by Liliana Betti; translated from the Italian by Joachim

Neugroschel. 1st Eng. language ed. Boston: Little, Brown, c1979.

, KEZICH, T., BOARINI, V., MOLLICA, V. II libro dei sogni di Federico

Fellini. Milano: Rizzoli, 2007.

\section{Roteiros:}

FELLINI, Federico. El Jeque Blanco, I Vitelloni, La Strada, II Bidone. Trad.

Esther Benitez, Madrid: Castilha, 1972.

. A Estrada. Rio de Janeiro: Civilização Brasileira, 1970.

- A Trapaça. Rio de Janeiro: Civilização Brasileira, 1972.

. Le Notti di Cabiria. Bologna: Cappelli Editore, 1965.

. Oito e Meio. Rio de Janeiro: Civilização Brasileira, 1972.

Prova d'Orquestra. Paris: Albatros, 1979.

e GUERRA, Tonino. Amarcord Trad. Eduardo Brandão. Rio de Janeiro:

Arte nova, 1975.

e ZAPONNI, Bernardino. Il Casanova di Fellini .Torino: Einaudi, 1976

Tre Passi nel Delírio. Bologna: Cappelli, 1979

. Roma - di Fellini a cura de Bernardino Zapponi. Bologna: Cappelli,

1972.

. Satyricon. Bologna: Cappelli, 1969.

. A Voz da Lua. Porto Alegre: L\&PM, 1990

\section{2 - Referências gerais:}

AGEL, Henri. Estéticas do Cinema. São Paulo: Ed. Cultrix, 1957.

ALBERS, Josef. A interação da cor. Trad. Jefferson Luiz Camargo; ver.de trad.

Fernando Santos. São Paulo: WMF Martins, 2009

ANDERSON, Bárbara, ANDERSON, Cletus. Costume Design. $2^{\mathrm{a}}$ ed. Orlando:

Harcout Brace College Publishers, 1999.

ANDRADE, Maria Margarida de. Introdução à Metodologia do Trabalho

Científico. 3.ed.Atlas: São Paulo, 1998.

AUMONT, Jacques. A Imagem. Papirus: Campinas, 1990.

. El rostro en el cine. Paidós: Barcelona. 1998. 
2004.

. O Olho interminável: cinema e pintura. Cosac \& Naify: São Paulo,

BARBARO, Umberto. Elementos de Estética Cinematográfica. Rio de Janeiro:

Ed. Civilização Brasileira S.A., 1965.

BARROS, Lilian Ried Miller. A cor no processo criativo: um estudo sobre a Bauhaus e a teoria de Goethe. $2^{\mathrm{a}}$ ed. São Paulo: Editora Senac São Paulo, 2007.

BAZIN, André. O Cinema - Ensaios. São Paulo: Editora Brasiliense, 1991.

BENTLEY, Eric. A Experiência Viva do Teatro. Rio de Janeiro: Zahar Editores, 1965.

BETTON, Gerard. Estética do Cinema. São Paulo: Martins Fontes, 1987.

BOSI, Alfredo. Reflexões sobre a Arte. São Paulo: Ática, 1985.

BRAIT, Beth. A Personagem. 3. ed. Ática: São Paulo, 1987.

BURTON, T., SALISBURY, M., DEPP, J. Burton on Burton. New York:

Macmillian, 2006

CÂNDIDO, A., GOMES, P. E. S., PRADO, D. A., ROSENFELD, A. A

Personagem de Ficção. São Paulo: Perspectiva, 1994.

CARVALHO, Luiz Fernando. Depoimento sobre o que é para ele a tividade de fazer cinema. Disponível em: <http://www.lavouraarcaica.com.br/principal.html> Acesso em 09 de junho de 2010.

CARVALHO, Luiz Fernando. Depoimentos sobre o processo de criação e confecção dos cenários e dos figurinos da Minissérie "Capitu". Disponível em:

$<$ http://tvglobo.capitu.globo.com/capitu/category/ruminacoes/> em 2 de julho de 2009.

EISENSTEIN, Sergei. Reflexões de um cineasta. Rio de Janeiro: Jorge Zahar, 1958.

O Sentido do Filme. São Paulo: Jorge Zahar, 2002.

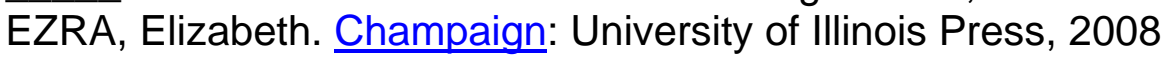

GEADA, Eduardo. Cinema e Transfiguração. Lisboa: Ed. Livros Horizonte, s.d.

GEADA, Eduardo. (org.) Estéticas do Cinema. Lisboa: Publicações Dom

Quixote, 1985.

GUERRA, L., LEITE, A. Figurino: uma experiência na televisão. São Paulo: Paz

e Terra, 2001.

GUINSBURG, J. (org.) et ali. Semiologia do Teatro. São Paulo: Perspectiva, 1978.

JEUNET, Jean-Pierre. Entrevista concedida a Francine Stock no programa $A$ Life in Pictures da BAFTA - British Academy of Film and Television Arts.

Disponível em: <http://www.youtube.com/watch?v=HndWfBhvQrk> Acesso em 30 de maio de 2010.

JUNG, Carl G., et. ali. O Homem e seus Símbolos. trad. Maria Lúcia Pinho. $4^{\mathrm{a}}$ ed. Rio de Janeiro: Editora Nova Fronteira, 1964.

JúNIOR, Redondo. O teatro e a sua estética. Arcádia: Lisboa, 1965.

KANDINSKY, Wassily. Do espiritual na arte. São Paulo: Martins Fontes, 2000.

Ponto e Linha sobre Plano. São Paulo: Martins Fontes, 2001.

LICHTENSTEIN, Jacqueline (org.) O Desenho e a Cor. São Paulo: Editora 34, 2006. ( A Pintura - Vol. 9)

LOMBARDI, Giovanna. Trecho do livro "Filoteo Alberini L'Inventore del Cinema"

Ed. Arduino Sacco, Bella (Potenza) 2008 Deisponível em:

$<$ http://findarticles.com/p/articles/mi 7502/is 200905/ai n39234518/> Acesso

em 24 de fevereiro de 2010. 
MACHADO, Arlindo. Serguei M. Eisenstein. $2^{\mathrm{a}}$ ed., São Paulo: Editora Brasiliense, 1982.

MARCUS, Millicent. Italian Film in the Light of Neorealism. New Jersey:

Princeton University Press, 1986.

MOSTRA INTERNACIONAL DE CINEMA DE SÃO PAULO Resenha do filme Cabíria inserida no site da $33^{a}$ Mostra Internacional. de Cinema. Disponível em: <http://www.mostra.org/32/exib filme arquivo.php?ano=30\&filme=6148> Acesso em 24 de fevereiro de 2010.

PECKTAL, Lynn. Costume Design: Techniques of Modern Masters. New York: Back Stage Books, 1999.

PEDROSA, Israel. Da cor à cor inexistente. Rio de Janeiro: Léo Christiano Editorial Ltda., 1977.

POE, Edgar Allan. Histórias Extraordinárias. Tradução de Breno Silveira e outros. São Paulo, Abril Cultura, 1978.

. Poemas e Ensaios; trad. Oscar Mendes, Milton Amado; 3. ed. São

Paulo: Globo, 1999.

SADOUL, Georges. História do Cinema Mundial: das origens aos nossos dias.

Lisboa: Livros Horizonte, 1983.

SENELICK, Laurence. Gordon Craig's Moscow Hamlet: A reconstruction.

Westport Connecticut: Greenwood Press, 1982.

STANISLAVKI, Constantin. A Construção da Personagem. Rio de Janeiro: $14^{\mathrm{a}}$ ed, Civilização Brasileira, 2004.

VIANA, Fausto R. P. O Figurino Através do Trabalho do Ator: Uma Abordagem

Prática. Dissertação (Mestrado). São Paulo: ECA - USP. 2000.

. O Figurino das Renovações Cênicas do Século XX. Tese de

doutorado, São Paulo: USP, 2004.

\section{FILMOGRAFIA do diretor:}

FELLINI, Federico. Mulheres e Luzes. P/B, 93 min, Itália, 1950.

. Abismo de um sonho. P/B, 85 min, Itália, 1952.

. I Vitelloni. P/B, 103 min, Itália, 1953.

. A Estrada da Vida. P/B, 94 min, Itália,1954.

. Il Bidoni. P/B, 104 min, Italia, 1955.

. As noites de Cabíria. P/B, 110 min, Itália-França, 1957.

A doce vida. P/B, 178 min, Itália-França, 1960

. A Tentação do Doutor Antônio. P/B, 60 min, Itália-França, 1962

Oito e Meio, P/B, 114 min, Itália-França, 1963

Julieta dos Espíritos, Cor, 120 min, Itália-França, 1965.

Toby Dammit, Cor, 37 min, Itália-França, 1968. (episódio de Histórias

Extraordinárias).

. Fellini - Satiricon, Cor, 138 min, Itália-França, 1969.

. I Clowns. Cor, 93 min, Itália-França, 1970.

. Fellini - Roma, Cor, 119 min, Itália-França, 1972.

.Fellini - Amarcord, Cor, 127 min, Itália-França, 1973.

. Fellini - Casanova, Cor, 170 min, Itália, 1976.

. Ensaio de Orquestra. Cor, 70 min, Itália-França, 1979

. A cidade das Mulheres, Cor, 145 min, Itália-França, 1980.

E la nave va, Cor, 132 min, Itália-França, 1983.

. Ginger e Fred. Cor, 125 min, Itália-França-Alemanha, 1985. 
. Entrevista. Cor, 113 min, Itália-França, 1987.

. A Voz da Lua. Cor, 118 min, Itália-França, 1990.

\section{FILMOGRAFIA sobre o diretor:}

BACHMAN, Gideon. Ciao, Federico!. Cor, 55 min, Itália, USA, Suíça, 1971. BOSCO, Paquito Del. Fellini: um auto retrato. Cor /PB, 68 min, Itália, 2000. PETTIGREW, Damien. Eu sou um grande mentiroso. Cor, 105 min, FrançaItália-Inglaterra, 2003.

PICCINI, Carmen. A Magia de Fellini. Cor, Itália, 2002

SESTI, Mario. A Última Seqüência. Cor. Itália, 2003.

\section{FILMOGRAFIA citada no capítulo 3:}

BURTON, Tim. Edward Mãos de Tesoura. Cor. 105 min, USA, 1990. . Batman Returns. Cor. 126 min, USA, 1992.

CARVALHO, Luiz Fernando. Hoje é dia de Maria. "Série TV", Cor, 566 min, Brasil, $2004-2006$.

. A Pedra do Reino. "Série TV", Cor. 276 min, Brasil, 2007. Capitu. "Série TV", Cor. 300 min, Brasil, 2008.

JEUNET, Jean-Pierre. Delicatessen. Cor. 99 min, França, 1992. . Ladrão de Sonhos. Cor. França, 1995.

. O Fabuloso Destino de Amelie Poulain. Cor. França, 2001. Cor, 120 min, França, 2001.

TORO, Guillermo Del. O Labirinto do Fauno. Cor. 112 min, México, Espanha, USA, 2006. 